HELMUT BORN

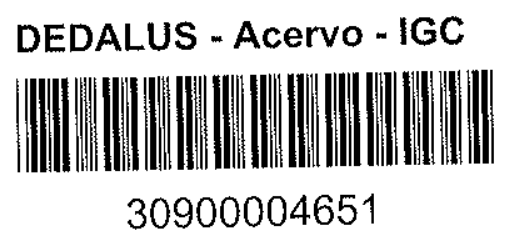

T.783

\title{
O COMPLEXO ALCALINO DE JUQUIÁ
}

TESE DE DOUTORAMENTO APRESENTADA AO INSTITUTO DE GEOCIENCIAS E AS. TRONOMIA DA UNIVERSIDADE DE SÃO PAULO. 
1) Generalidades l

2) Trabalhos Anteriores 3

3) Agradecimentos 5

IJ - FISIOGRAFIA

1) Relêvo 7

2) Clima e Drenagem 8

3) Intemperismo 9

III - GEOLOGTA 10

1) Aspectos Gerais 10

2) Rochas Encaixantes do Coxpo Alcalino 13

a) Distribuigão e Estruturas 13

b) Petrografia 20

3) Piroxenitos 22

a) Modo de Ocorrêneia e Distribuicão 22

b) Mineralogia 24

c) Petrografia 29

4) Ijolitos 35

a) Modo de Ocorrência e Distribuigão 35

b) Mineralogia 36

c) Petrografia 41

5) Sienitos - 46

a) Modo de Ocorrência e Distribuigäo $\quad 16$

b) Mineralogia 47

c) Petrografia 54

6) Rochas de Diques 62

a) Modo de ocorrência e Distribuigäo 62

b) Mineralogia 63

c) Petrografia 66 
7) Carbonatitos

a) Modo de Ocorrência e Distribuicäo

b) Mineralogia

c) Petrografia

8) Fenitizacão

94

9) ReZaçöes de Campo

209

215

IV - CARACTERISTICAS GEOQUTMTCAS

1) Amostragem

2) Preparagão das Amostras

3) Dosagem de Fósforo

4) Resultados

b) Dosagem Total do Fósforo

5) Conclusões 


\section{INDICE DAS ILUSTRACOES}

1 - Localizagão do Complex Alcalino de Juquí.

2 - Pexfiz topogräfico, geolögico, cintizométrico e magnetomëtrico atravếs do corpo alcalino de Juqui $\vec{a}_{0}$

3 - Diagramas de distribuigäo de lineamentos foto geolögicos em tôrno da intrusa alcaïina.

4 - Diagramas de distribuigà de ineamentos foto geolögicos por quadrantes, na ärea pröxima a intrusão alcalina.

5 - Distribuigăo dos carbonatitos no Morro do ser rote.

6 - Termogramas de carbonatos do acrbonatito de Juquiä。

7 - Termogramas de carbonatos do carbonatito de Juqui $\ddot{a}$ 。

8 - Variagão dos teores de sro e ra em carbonatitos de Juquiä。

9 - Indice alcali-calcico das roohas de Juquia.

10 - Comportamento geoquimico de aiguns elementos nas rochas alcalinas de eruquiti.

11 - Comportamento geoquimico de alguns eiementos nas rochas alcalinas de Juquia.

12 - Diagrama triangular Fe-AlK-Mg e K-Na-Ca das rochas alcalinas de Juquia.

13 - Gräfico dos resultados obtidos por dosagem geoquimica, em comparaçäo com a analise quimica. 
14 - Perfis de prospecsão geoquimica no Morro do serrote e rochas alealinas vizinhas.

15 - Resultados de dosagem geoquimica total e parcial, em solos oriundos de diversas rochas da intrusão de Juquia.

TABELAS

1 - Composicao modal de algumas rochas ultra bäsicas da intrusäo alcalina de Juquiä.

2 - Composifäo quimica de rochas piroxeniticas.

$2 a$ - Normas moleculares de duas rochas piroxe niticas de Juquia.

3 - Composigao modal de algumas rochas ijoli ticas de Juquiä.

4 - Composigäo quimica de rochas ijoliticas.

4a - Normas moleculares de rochas ijoliticas de suquiä。

5 - Composigäo modal de sienitos da intrusấo alcalina de Juquiä.

6 - Composigão quimica de algumas rochas sie niticas de Juquia, comparadas a mëdias de diversas localidades.

$6 a$ - Normas moleculares de alguns sienitos da ărea de Juquiä.

7 - Composigá modal de alguns diques de suquiå。 
$p$

8 - Medidas do indice de refragão w em carbona tos provenientes do carbonatito interno.

9 - Composicão quimica de algumas rochas carbo natiticas de Juquiّa e de dolomitos do emba samento。

10 - Composicäo quimica de carbonatitos ricos em magnësio.

11 - Composigäo quimica em base cationnica de al gumas rochas de Juquïٌ。

12 - Comparacáo entre resultados obtidos por do sagem geoquimica e analise quimica, em so Los do Morro do serrote.

13 - Repetifäo de dosagens geoquimicas paxa con. trôle da reprodutibilidade dos resultados.

14 - Determinacôes, por filuorescencia de raios $X$, de $\mathrm{Ce}, \mathrm{La}, \mathrm{Y}$ e $\mathrm{Nb}_{2} \mathrm{O}_{5}$, comparados aos teores de $\mathrm{P}_{2} \mathrm{O}_{5} \mathrm{O}$

FOTOS

1 - O Morro do Serrote visto pelo flance oeste...

2 - Dique de carbonatito branco cortando a rocha tambëm carbonatitica.

3 - Bloco de composigăo argitosa e côr avermetha da, engzobado por fosfatos, tratando-se de um possivel xenotito alterado. 
8 e 9 - Feicoes devidas a repreaipitacao de fosfatos, dando origem a camadas naod sas e finas de minerios intercaiadas com material pulveruiento e terroso.

10 - Amostra de fosfato com cavidades rom boèdricas, preenchidas por material pulverulento.

1 - Mapa geolögico do complexo alcalino de suquia.

2 - Lineamentos fotogeolögicos na ärea do complexo alcalino de juquia.

3 - Localizacaio das amostras citadas no texto. 


\section{$I-I N T R O D U C \tilde{A} O$}

\section{,1) - Generalidades}

o complexo alcalino de Juquiä constitui uma das numerosas ocorrências de rochas insaturadas e subsa turadas associadas a carbonatitos do sul do Brasil. As denominasões Serrote e Guaviruva, frequentemente encon tradas na literatura, referem-se a diferentes locais da mesma ocorrência. Optou-se pela denominacão Juquiă por ser esta a cidade mais proxima, facilitando sua locali zacão. O têrmo serrote, talvez mais conhecido, alëm de ser um nome muito comum na regĩa, onde designa três ou quatro locais diferentes, refere-se apenas ao morro onde ocorre o carbonatito. o complexo se situa cêrca de $50 \mathrm{~km}$ a nordeste da intrusäo aloalina de Jacupiranga, uma das mais conhecidas do Brasiz. 
Embora a existênoia de baxita e magnetita te nha atraido, intoialmente, a atencáo para a ärea em ques tăo, os fosfatos constituem a oooxencia minexat de maiox interesse, sendo Lavrados em pequena escala no Morro do Serrote. os trabalhos existentes sobre a geologia locat. são poucos e, em sua maioria, tratam apenas de aspeotos econômicos. Um estudo mais detalhado mosirou que o modo de ocorrência das rochas de Juquia, as associagoes petro gräficas e mineralögiras caracterïsticas, a fenitizasăo das encaixantes, cextas feigöes tectónicas, bem como a presenfa de diques, säo tipicos das intrusöes alcainas desse tipo, localizadas em värias regiöes de plataforma estävel.

o complexo aloalino de Juquiä localiza-se na parte sudeste do Estado de sao paulo, no municipio de Re gistro, entre as cidades de Juquia e Registro; disia 169 $\mathrm{km}$ de säo Paulo peta rodovia Rëgis Bittenoouxt, BR-1 iblan tiga BR-2), que une sâo Paulo a Curitiba. Suas doordenadas aproximadas säo $47^{\circ} 44^{\prime}$ Longitude oeste e $24^{\circ} 24^{\prime}$ la titude sul (Figura 1 :

As rochas alsabinas situam-se pouco do sut do Sexra das oncas, ocupands uma ärea de aproximadamente is, 5 $\mathrm{km}^{2}$, na Baìada littorânea.

A vista do interêsse que as intrusöes aloal nas e os resursos minerais a elas assootados vêm desper tando, tanto no Brasil como no sxterior, pareceu justifi. cado um estudo mais detalhado da intrusäo de Juquia. Este trabatho teve por objetivos permitix a methox caractexis săo geológica do distrito e a sua comparagäo com loxalida des congêneres. Alèm disso, do ponto de vista economico, essa caracterizagão podexä ser de utilidade prätica. As conclusoes sobre a origem dos depositos fosfäticos, obst das do estudo mineralögito do carbonatito, do minéxio res sidual e secundârio e dos solos residuais, bem como das observacoes de campo, poderäo ser importantes na debermi nagäo das reservas e na pxogramagäo da lawa. 
A presenca de minerais radioativos no carbonati to, ja sugerida por Leonardos (1956). foi verificada por di versos meios para avaliacão de sua importâncïa.

A aplicação experimental de um mëtodo de dosa gem geoquimica do fósforo contido em solos foi executada, afim de verificar sua aplicabilidade na localizacäo de jazi das fosfäticas semelhantes, bem como na determinaçao aproxi mada de contatos do carbonatito. A área se presta para essa tentativa, pois ainda não se encontra muito afetada por trabalhos de mineração.

o estudo detalhado do carbonatito permitiu reco nhecer varias caracteristicas importantes para a interpreta são de sua petrogênese e modo de intrusäo. Foram identifi cados diversos minerais caracteristicos de carbonatitos co nhecidos em outros paises, que ainda näo haviam sido descri tos em ocorrências brasileiras. Quimicamente, verificou-se que a rocha carbonatitica de Juquia se caracteriza por ele vado teox em magnësio, o que a distingue da grande maioria das demais localidades congêneres.

Para a execuçäo do presente trabalho foram efe tuados levantamentos de campo, que constaram do estudo de todos os afloramentos encontrados na axea, de amostragem de solos, feita com detathe em alguns perfis para finalidades de dosagem geoquimica de fosforo em solos, de medidas magne tomëtricas e cintilomëtricas. Durante os trabalhos foram de grande utilidade as fotografias aéreas, na escala apraxi mada de 1:25 000, executadas pox Levantamentos Aeroforogra mëtricos Cruzeiro do SuL S.A. em 196\%, para o Instituto Agro nomico de Campinas. Baseado nessas fotografias foi feito o mapa planimëtrico da regiäo do complexo alaalino e oixcunvi. -khangas, onde foi langada a geotogia, bem como o levanta "rento das fraturas e lineamentos fotogeologicos.

\section{2) Trabalhos Anteriores}

A ärea em entudo fot menoionada peta primeira 
vez por Leonardos (1934), que noticiou uma ocorrência de barita descoberta em 1927; êsse autor se refere ainda a uma rocha pox êle denominada sienito gnaís. Knecht 2934 e 1940) também se refere à ocorrência de barita no Morro do serrote.

Em 1938, tëcnicos do Instituto Geogräfico e les Lögico notaram a existênoia de magnetita, realizando-se en tão um estudo que visava examinar a possibilidade de seu aproveitamento econômico (Knecht e Felicissimo Jr. - 1939). Foram reconhecidas na ocasiäo divexsas variedades de rochas alcalinas, como sienito e ijolito. Maior atencão foi dispensada ao Morro do serrote, pois ali se localizaram as principais ocoreencias de ferro. o calcario dolomitico, constituinte da maior parte do morro, seria de oxigem sedi mentar, provãvelmente da Sërie säo Roque. A origem da mag. netita estaria estreitamente ligada a intrusäo ijolitica, que, por sua vez, seria um têrmo de diferenciagăo magmática do sienito, em contato oom o caicairio.

Camargo (1942) publicou breve nota mineralógica sobre a barita do serrote.

Knecht (1948) fêz uma sërie de comparagöes entre as ocorrências de Jacupiranga e Juquiä, inclusive mencionando a hipötese de uma correlagáo estratigxäfica entre os calcários das duas localidades. No mesmo trabatho, no ticia que Eelicissimo $J x$. havia reconhecido, no Morro do serrote, grandes reservas de fosfatos secundarios lfosfori. to).

Guimaxães e Eetioissimo Jx. (1950), em artigo sôbre recursos minerais do Estado de säo Paulo, referem-se a fosfatos ocorrentes no Morro do serrote em Guaviruva.

No Local denominado Guaviruva, Localizado um pouco a sudoeste do Morro do Serrote, Maciel (1952) descre ve uma jazida de fosfato no contato de sienito com piroxe nito, atribuindo sua origem a processos de segregacäo maq mätica. Entre as rochas Locais, descreve peridotito, piro 
xenito, sienito e pegmatito.

Leonardos (1956) publicou a primeira referência à existência de carbonatito em Juquiä, numa coletânea sobre os carbonatitos brasileiros.

Desde entäo, a localidade tem sido citada com frequência, como ocorrência alcalina com carbonatito, com base nos trabalhos acima citados.

Em recente publicagão, Felicissimo Jx. (1268), tratando de caxbonatitos no Estado de São Paulo, dä al guns pormenores sôbre testemunhos de carbonatito do Morro do Serrote, obtidos jă na dècada de 40 , dos quais näo se tinha conhecimento, pois fazem parte de um relatörio de pesquisa inédito do mesmo autor (1948).

\section{3) - Agradecimentos}

o autor deseja expressar seu reconhecimento às seguintes entidades: Conselho Nacional de Pesquisas, pelo auxilio que permitiu obter analises quimicas das rochas silicatadas; Servico do vale do Ribeira, da se cretaria de Servigos e obras püblicas do Estado de Săo Paulo, através do Convênio DAEE-USP, pelo auxilio refe rente aos trabalhos de campo, de laboratörio, bem como algumas anälises quimicas em carbonatitos; Instituto Geo gräfico e Geologico do Estado de säo paulo, pelas faci Zidades de acesso e consulta a todo o material disponivel sôbre a regiäo de Juquiă; socal $S . A$. Minerasão e In tercâmbio Comercial e Industrial, por ter permitido a execusão de trabalhos de campo em suas propriedades; ser rana S.A. de Mineragão, pelas anälises quimicas de car bonatitos e permissão de consulta de alguns dados adi cionais.

Tambëm ficam regis rados os agradecimentos aos värios ex-alunos do Curso de Geologia da U.S.P., que cooperaram nos trabalhos de campo e de laboratório; ao 
Sr. Denis William de Abreu Mendonsa, pela elaboracăo das ilustragoes; a Sra. Nair de Campos Louzada pelo trabalho de datizografia.

o autor agradece especiazmente aos colegas $D^{2}{ }^{\prime} N_{0}$ EZlert, pela colaboracaio na parte referente a magnetometria; Dr. JoM. V. Coutinho e Dr. CoB. Gomes, pelo auxilio e discus söes referentes a petrologia: Dr. E.C. Damasceno, pelas dis cussöes, observacôes e leitura do texto; bem como a todos os colegas que, de uma ou outra maneira, prestaram sua ajuda. - autor deseja, ainda, manifestar especial reconhecimento do seu orientador, Dr. GoC. Melcher, pela dedicacäo, apöro e in centivo, durante tôdas as fases de preparacao do trabalho. 


\section{IT - ETSTOGRAFTA}

1) - Rezêvo

A ârea em estudo localiza-se na extensa Baixu da titorânea, existente na parte sudeste do Estado de säo

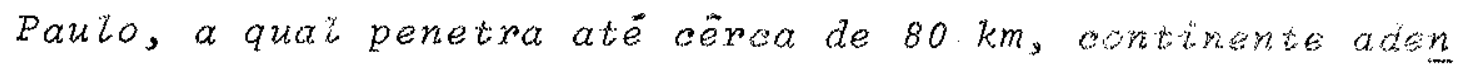
tro. Esta baixada constitui uma vasta planto sedimertar. drenada pyincipalmente peto rio Ribeira de Igape be bu afluentes, estando limitada pelas escarpas do Planabo A thantico, de relevo acidentado e cotas gexamenta zupe xiores a $800 \mathrm{~m}$.

Na Baixada lithona for form reconhedido is rios niveis de beraceamento marinho e seus correspondentes texragos fluviais lstzierzo, 1950; Freitas, 195\%;

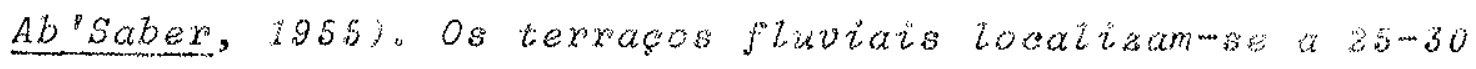
$m$ e 50-60 m, acima do nivez do wio Ribetra, haverdo, alsm

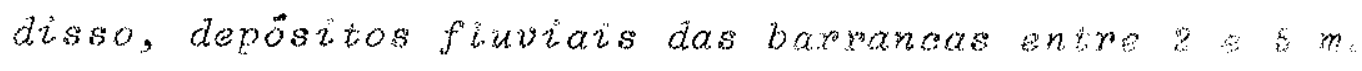

os oursos de ägua da ared estäo proximos no nivel de base looal, representado pelo roto Ribetro de Iguape. Os morros da regiäro näo ultrapassam algumas dese nas de metros, porem, às vezzes, essa regrzaridade

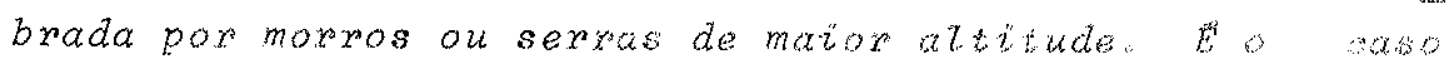
da serra do Itatins, com elevagoes acima de l oon ms qua forma fatésias ao atingir o litorat entre as praias do pe ruibe e Una; payo interiox, as elevagoes tornam-a wada ver mats suaves, oonstitutindo as serras do Banamat a das ongas, desaparecendo pox fim mos aturobes da batada.

o complexo atoalino de duqutä sutua-se na bat xada, pouco ao sul da serra das ongass. os washos que are nam a ärea tiem alizitudes em tồno de $7 m \in$ originam-y em brejos, que ocupam grande parte das areas baixas. os mox ros apresentam altitudes entre 60 e $70 \mathrm{~m}$, geralmense com suas partes attas quase niveladas. As elevacoes mals us tas sao o Mro do serrote sis mis Morro da casa de pe dra e algumas outras mais priximas da sexya das ongar. os 
morros de aititudes mais ou menos uniformes e chmes ango aplainados, incissive a parte leste do Morro do berpots. pareoem estar retacionados a um antigo rityot da wasa

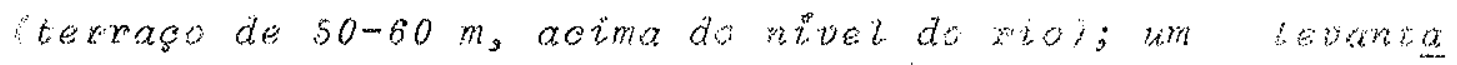
mento posterion da area causou a retomada da erosio e for

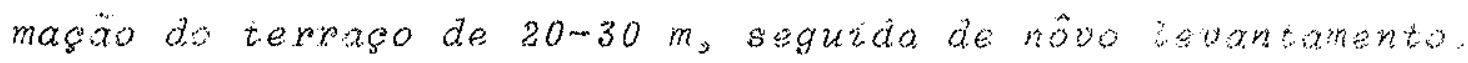
Atualmente, o nivel de base da regrat foi quase atingtido. sendo nomuns as varzeas e brejos com aluvtore reoentes on tre os norrotes que sobressam na topografia mos quats a exasio ainda $\vec{e}$ ativa.

\section{2. - Clima e Drenagem}

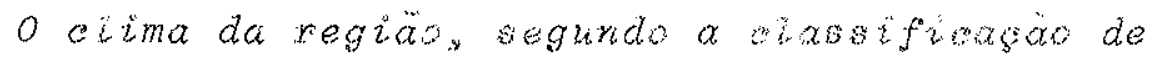
Koppen, é do tipo mesotërmiso subtroptoal unjay sem es

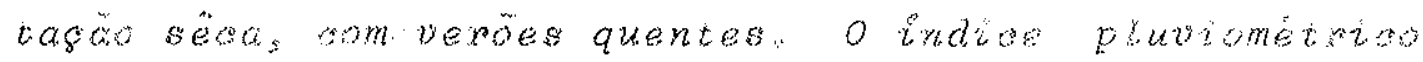

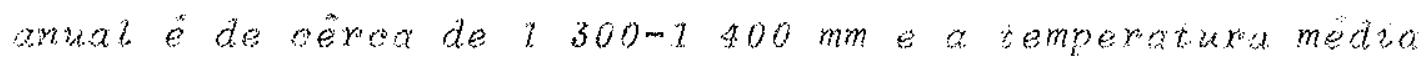
anual de $2 \%, 70 \mathrm{C}$, de acordo som dados obtidos em inquiá (Setaex, 1946). As chuvas predomintrm no verao lasambro e fevereiroj, enquanto a estaca menos chuvod andide oom a epoca mats fria do ano junho agostos.

A ärea do complexe utealino dista aprotimadam mente $35 \mathrm{~km}$ da oosta e far parte da sxtevsa baixada dre nuda peto rio Ribeira de rguape. Estes na cidade do Re gistro, esta a poucos metros arima do níbel do mar. Os robeiross Biguâ e Guaviruva, que drencm a regian do oom plexo originam-se nos brejos que oirandum morro do

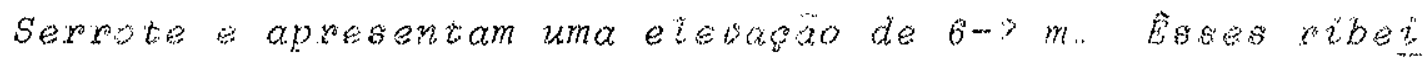
röes se unem e desaguam no vio peropava, afluente da max gem esquerda do rio Ribeina de Iguape, oxrendo semper em aluvioes. 
Devido às condigöes climäticas da regira o in temperismo è muito ativo. o mesmo deve ter ocorido em épocas pretéritis, pois, ao longo da rodovia Rëgis Bitien court, existem cortes com dezenas de metros de altura, nos quais muito comumente so se cnochtram roohas semi-alteradas, cobertas pox espêsso manto de intemperismo. Essa rodovia corta rochas prë-cambrianas, constituidas por xistos,gnats ses, quartzitios.

o intemperismo intenso agiu, tambëm, sobre as rochas alcalinas, auxitiado por algumas caracteristicas a elas inerentes, tais como: a ausencia ou escasses de quart zo; presensa de minerais como nefetina, olivina, augiti, mais instaveis quimicamente; arobonatos mais facimente so lubilizados; eto.

De um modo gerat, a seqllencia de inswabizidade das rochas aleatinas ë a seguinte: peridotito - piroxeni to - ijolitowsienito - ffenito w, devendo-se ensiderar, tambëm, a influência da granulaçăo.

De relativa importäncia devem ter sïdo, ainda, as variacoes do nive: freatico da regiao, resuliantes de värios levantamentos relativamente pequenos, mas distintos, como se deduz dos divexsos niveis de terragos existentes. Is to permitiu que o intemperismo atingisse locais cada ves mais profundos, bem como sua agäo consinuada sobre blocos de rocha, porventura restantes no manto intemperisado.

Alëm disso, na maísria das exposiços de rocha, torna-se dificil distinguir entre afloramentos realmente representativos das rochas subjacentes b bocos que podem estar destocados de sua posiäo original, ou ainda, repre sentar apenas porcoes limitadas mais reststentes das roshas originais. Pox exemplo, sm determinadas areas sal abundantes blocos de rochas de diques, embora êstes ooupem, apenas, pequena fracäo de area totat. 


\section{III - GEOLOGIA}

\section{1) - Aspectos Gerais}

A intrusão alcalina de Juquià estä encaixada em rochas metamöxficas pré-cambrianas, representadas no local predominantemente por gnaisses, alëm de quartzitos e mica xistos subordinados.

Nas proximidades da intrusão não ocorrem calcä rios ou dolomitos de origem sedimentar. Sömente pequenas lentes de rochas carbonäticas ocorrem na região, as mais pröximas a cêrea de $17 \mathrm{~km}$ a ENE'.

o complexo apresenta forma irregular, com maior dimensão de $5,4 \mathrm{~km}$ na diregão $E-W$ e eixo menor de $4-4,5 \mathrm{~km}$ na diregão $N-S$. As rochas encontradas podem ser agrupadas preliminarmente da seguinte maneira: piroxenitos e perido titos, sienitos, ijolitos e carbonatitos, alëm de rochas afetadas por metassomatismo de contato, entre as alcalinas $e$ as encaixantes. Os contatos entre os diferentes tipos de rochas não puderam ser seguidos em afloramentos, devido ao espêsso manto de intemperismo, que cobre a quase totali dade da ärea.

Fatôres que auxiliaram na delimitacão das äreas ocupadas pelas diversas rochas foram os minerais residuais $e$ a variagão na coloragăo dos solos. Entre os minerais re siduais mais comuns estão o quaxtzo e a magnetita, além de mica alterada, apatita e alguma titanita. Grande parte do ferro aparece sob forma de óxidos hidratados secundários. Alëm disso, em alguns locais onde o processo de intempexismo foi menos intenso, notam-se restos de piroxênios. A colorasão dos solos è de utilidade, principalmente na deli mitasão das àreas ocupadas por rochas básicas e ultrabäsicas, dada sua tonalidade vermetha escura devida à grande quantidade de öxidos de ferro.

Outro subsidio para a detimitąão da ärea ocupa da pelo complexo e suas diversas variedades petrogräficas 
foi a execugäo de alguns perfis magnetomëtricos e antize métricos.

A magnetometrias apesar do numero medusido de medidas e do seu espagamento bastante grande, fornesen is? guns dados complementares thteressantes, principalmente so bre a distribuigão das rochas ultrabasicas e do sarbonat: to. A Figura 2 representa um perfil magnetomètrico de som ponente vertical, associado a pexfis antilométrios fopo

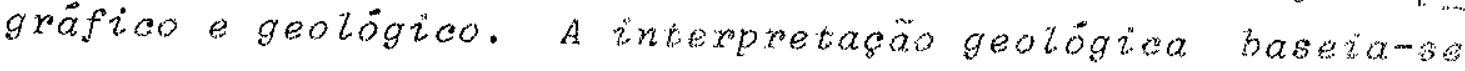
tanto nos dados de campo como na magnetometria 1 bs walo res da magnetometria säo aproximados de mais ou menos zo y, pois não foi efetuada a consegäo diurna). A irregularida de da curva magnetométrica pode ser, em parbe, devida a mag netita residuat dos sotos. o espacamento das medtass, pas tativamente grande, s0̈ perminte uma sorrelacăo aproximadr com a litologia existente, uma ves que alguns dos valswess obtidos, provàvelmente, sáo erräitoos.

A antrtometria, por bua vez, apenas thangou uma anomalia nas proximidades do rabonatito e sera rratada com maior detathe na parte a ête refexente.

Diques de rochas atodinas foram enconsrados sm difexentes pontos, com mais frequencia cortiando os stiens tos looalizados no Morro da Casa de pedra. Devem, no a canto, ocoxer em växios outros locals, pois seus fragmers tos e biocos säo abundantes am algumas äreas baixas, proven velmente ocupadas por rochas witrabästoas pouros diques foram localizados cortando as roohas entaxantes, mas o pe queno nümero de aftoramentos ë fator limitante na sua de teceão. Na regiäo tamberm existem diques de roohas iampro firicass de atitude desconhecida, conforme se conotut pelin presenca de pequenos blocos dessas rochas em alguns ponson da ärea.

A existência de xenötitos nă foi comprovada. mas ė sugerida por certas massas alteradas na fisente ds ma nexagào. sua frequência e naturesta exata somente poderixh sex vexificadas em exposigoes maiores e menos intempexizaz das. Näo existem na area quatsquer evidencias de vubrans mo ou rochas extrusivas. 


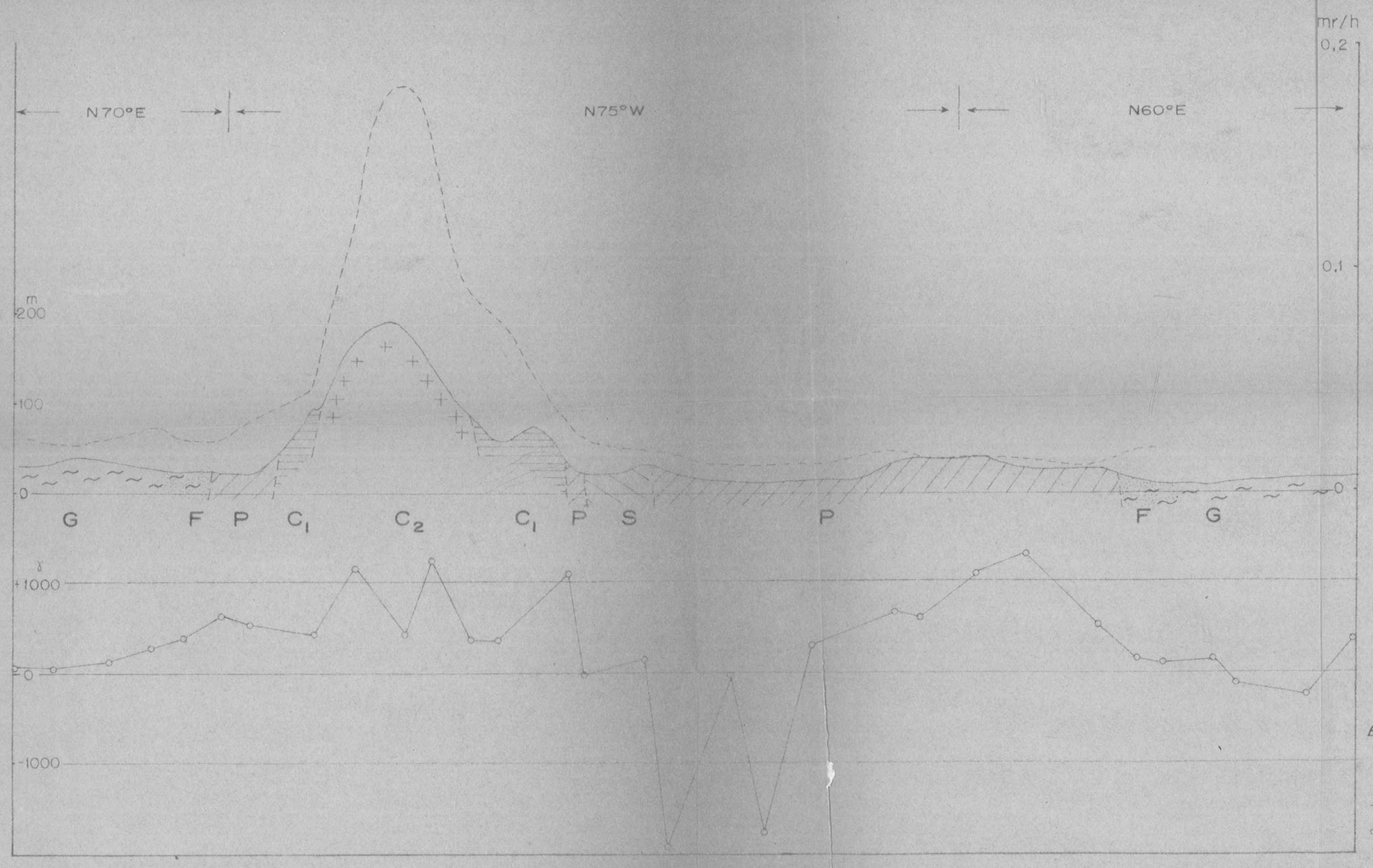

$\mathrm{C}_{2}$ Carbonatito mais recente

$C_{1}$ carbonatito mais antigo

5 Sienito

P Piroxenito

F Fenito

$G$ Gnaisse

Fig. 2 : Perfil topográfico, geológico, cintilométrico e magnetometrico airavés do corpo alcalino de Juquic

Escala horizontal aproximada

1. 25000

Curva de intensidade
radiootiva relativa Componente mognético
vertical 


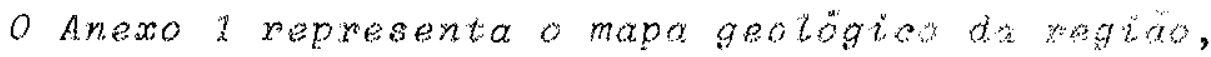

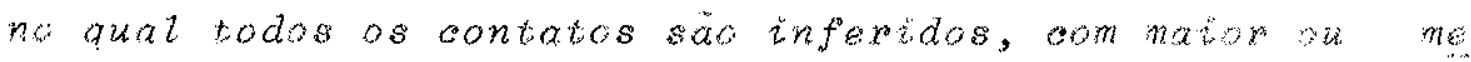

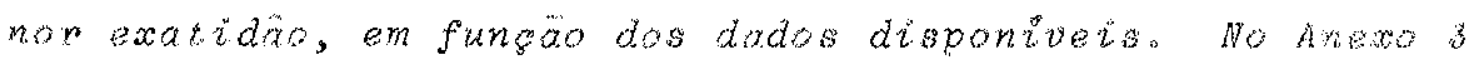

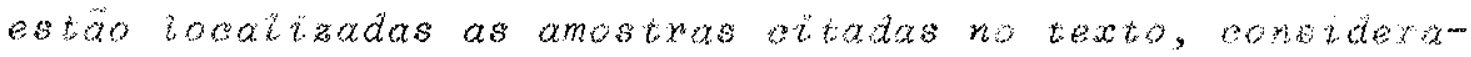
das representativas da area.

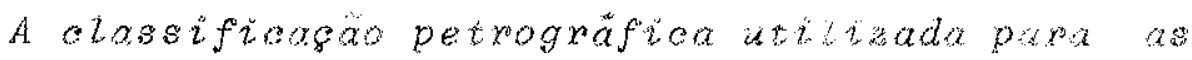

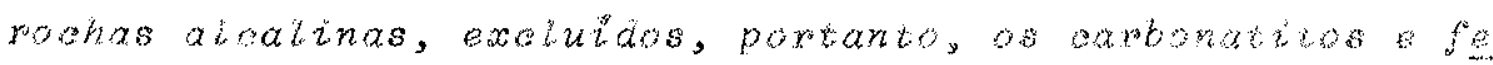

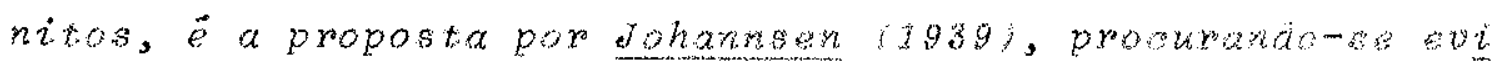

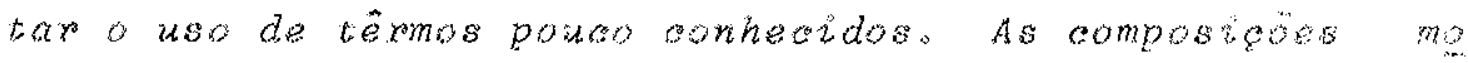

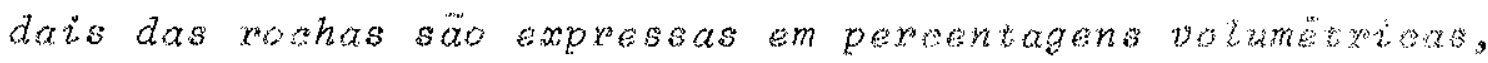
obtidas mediante contagem de pontos "Chayes, 1949 . Na mate

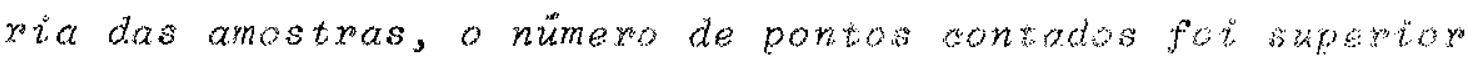
a 1000 .

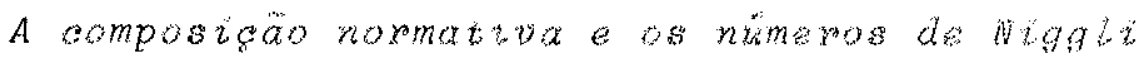

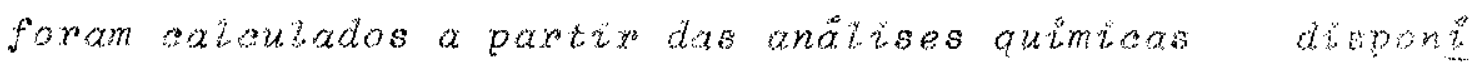

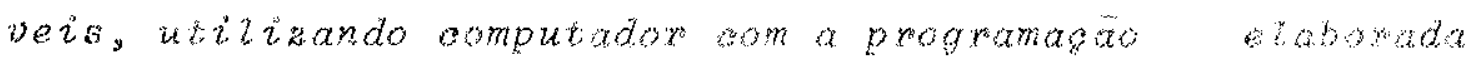

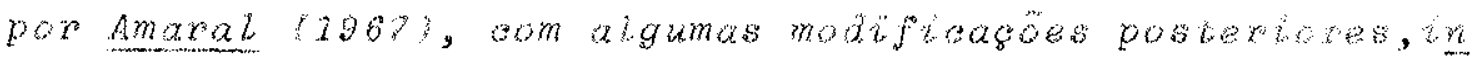
sxoduzidas pelo mesmo aukor.

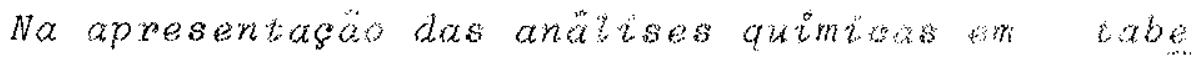

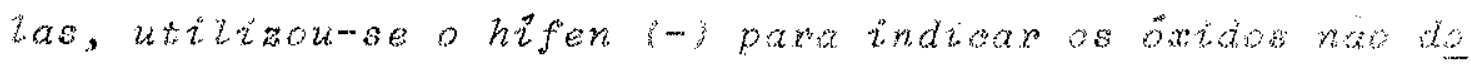

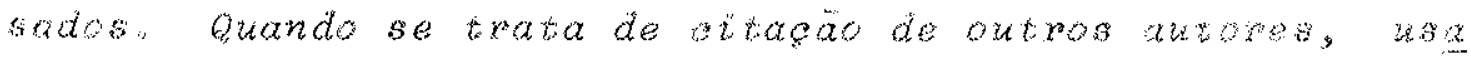

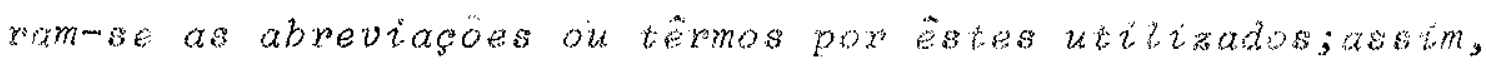
por exempio, witagöes de Johansen podem apresentar w

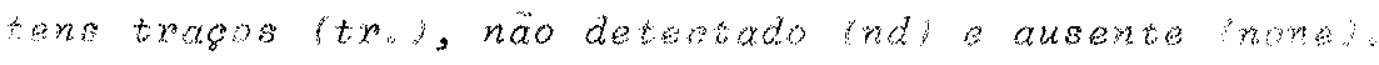

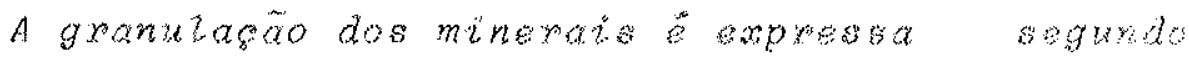

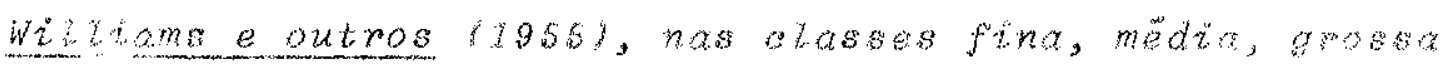

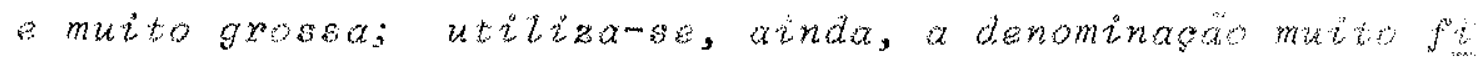
na, para graos menowes do que $0,2 \mathrm{~mm}$.

\section{2) - Rochas Enoaixantes do Coxpo Aloxino}

\section{a) - Diteribuigad e Estataras}

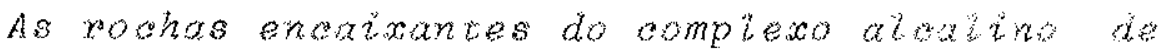

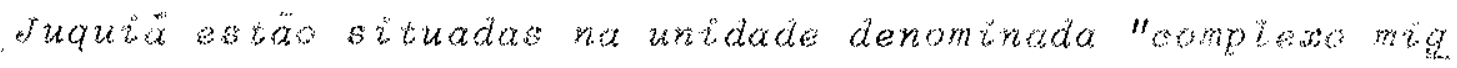

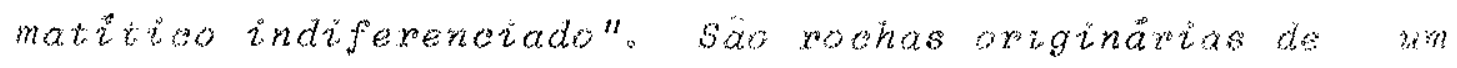


antigo miogeossinclinal prë-cambriano que foi dobrado, re sultando grandes dobras de orientagão geral nordeste-sude este, havendo intrusao de granitos sintectônicos paitingene ticos em nücleos de antiolinais Melfie outros, 2965. De maneira geral, na regiäo sul do Estado de são pauto, grax de metamorismo das rochas aumenta de noroeste pora sudesse. havendo uma mudansa na litologia, pois no alto Vale do Ri beira predominam filitos. caloarios e quartitios, enquanto prỏximo à costa, prevaleoem gnaisses migmatiticos e xistos, havendo apenas localmente quartzitos e lentes de valcario. A faixa onde dominam gnaisses e granitos era anteriopments considerada mais antiga, pextencente ao arqueano; no encan to, a falta de discordäncia e o aumento graduat do metamox fismo, observado em muitos trechos, Levaram a considexar que pelo menos grande parte dos gnaisses e migmatitos con responde aos mesmos sedimentos que deram onigem aos fili tos, mas que sofreram metanoxfismo mais intenso "Morais Re go, 1933 ; Melfi e outros, $1965 ;$ Serv, do Vale do Ribetra, $1966 \%$

Emboxa jä extsta volumosa bibliografiz sobre di versos aspectos da geologia do Grupo Agungui, swontram-se apenas referêneias isoladas sobre os gnaisses da falxa wos teira. Nao existe nenhum trabalho de carater regronal to bre a axea em que se sivua o romplexo de Juquia. Roshas de grau de metamorfismo semelhante foram descritas, wecente mente, no Estado do Paxanä pox Fuek Trein e Marini $196 \%$ Cordani e Girardi (1967) Girardi (7969).

Determinacöes radiométrioas de idades das morhas do Grupo Açungu e de gnaisises migmatiticos, pelo méto K/Ax, efetuadas no Centro de Pesquisas Geocronoliginar da Universidade de são Paubo, indicaram que a deposigào dos sedimentos se deu hä mä̈ de 650 mithöes de anvis porsm, ainda no prë-Cambriano superior, tendo a principat fiase oxu gênica, bem como a intrusäo dos granisos, ocorrido extre 600 650 milhöes de anos Cordani Bittencourts $106 \%$ Essa fase parece estar relacionada a vertogenese Baikatz anc, de grande importancia em todo o Bxasil. Almezad, 1967. 
p.11-19).

o complexo alcalino de suquia esta circundado, er. sua maior parte, por rochas anaissicaso Quartzito door re em pequena extensao no contato noroeste de intrusüo. nos flancos e na base do Morro da Casa de Pedra. pouco afastados da intrusäo, na diregaco norte, foram encontra dos quartzo-mica xistos alterados, de distribuigao restri ta。

Emboxa näo aflorem calcarios tmediatamente em redor do corpo alcalino, ë interessante conhecer as carae teristicas das rochas carbonaticas mais pröximas, perten. centes ao embasamento. Na estrada Bigua-Iguape, $17 \mathrm{~km}$ a ENE da intrusaio, a cerca de $4 \mathrm{~km}$ da rodovia BR-116, ocos rem 3 Lentes de dolomito com espessuras em tôrno de $10 \mathrm{~m}$. encaixadas em migmatitos de opientacäo proxima a $E-W$. Tratase de dolomito branco sacaroide, de granulacio gros sa, impuro, sendo que uma das lentes mergutha cerca de 600 para norte e outra $70^{\circ}$ para sul.

A diresaio de xistosidade dos gnaisses na regito da intrusão varia entre $N E$ e $E$. $W_{3}$ com merauthos fortes para SE ou verticais, observâveis por exemplo, em fotogra fias aëreas da serra das ongas, onde ocorrem värios "dip slopes". Medidas de xistosidade em afloramentos e rochas semi-alteradas proximas a intrusaio apresentam diresous bas tante variäveis, entre $N$ 20-80 $\mathrm{E}$, com mergulhos de $400 \mathrm{SE}$ a verticais. Verifica-se, portanto, que nas imediasoes do complexo alcalino ocorreram consideraveis deformacoues nas rochas encaixantes, embora rao se tenha estabelecido nenhu ma estrutura caracteristica de intrusäo forsada.

A intrusaio de rochas alcalinas, segundo Almeida (1967. p. 26), parece estar relacionada a uma fase de maior atividade tectônica, caracterizada como reativacăo Wealdeniana, que se fêz sentix com maior intensidade nas regioes costeiras e suas proximidades.

Im diversas localidades onde ocorrem chaminess de rochas alcalinas, nas encaixantes graniticas ou gnaissi cas verificou-se o desenvolvimento de nitidos sistemas de 
fraturas radiais e concêntricas, às vêzes preenchidos por diques de rochas alcalinas. Exemplos de fenômenos tectôn cos dêsse tipo säo as provincias de Fen, Alnu, Chilwa, spitskop, Kalkfeld, Anitäpolis e outras, descritas pox di versos autores.

Na regiäo de Juquia, entretanto, o profundo in temperismo impossibitita a tocalizagáo de fraturas ou a me dida da atitude de diques, no campo. Com a finalidade de verificar se ocorreram fenômenos dëste tipo, foi executada a inierpretagăo fotogeolögica, em escala $1: 25000$, de uma ärea aproximada de $20 \times 13 \mathrm{~km}$, em tôrno da intrusäo alcali na. As observagöes feitas estão representadas no Anexo \% (reduzido de 50\%).

Nas fotografias aéreas säo observäveïs numero sos lineamentos fotogeológicos que podem ser alassificados em dois tipos:

1 - Lineamentos representados essencialmente pox pe quenas depressóses, situadas nas areas mais ele vadas. Essa feicão ë methor observävet nas re giones desmatadas. De uma maneira geral, ezas formam grande ânguto com a orientagào geral das rochas.

2 - Lineamentos relacionados à rëde de axenagem, re presentados por vales retilineos, em parte pre enchidos por aluvioes.

Estes dois tipos de lineamentos correspondem em sua maioria a fraturas ou diäclases e, subordinadamente, à diregáo dos metassedimentos.

A dificuldade de interpretagäo do mapa obtido re side no fato de que os fraturamentos devidos à intrusao mag mätica se sobrepöem às orientasoes anteriores dos gnaisses e dos sistemas de fraturas que éstes apresentariam em conse quência de deformaçöes independentes do magmatismo.

Considerando-se apenas os lineamentos mais desen volvidos, que em geral coincidem com as principais drena gens, observa-se que hä predominânoia de duas dixecöes, $N E$ 
a E $N W$ a $W$, que correspondem, respectivamente, à dregao gerat das camadas encaixantes e uma direcáo perpendioutar.

A fim de verifinar se nas proximidades da intru. sao ocorre um padrão de fraturamento diferente do regionat, fes-se o levantamento da diregálo dos lineamentos om três areas: 1-Area da intrusas; 2- Area imediatamente vizinha $\ddot{a}$ intrusăo, sütuada dentro de um raio de $5,5 \mathrm{~km}$ do centro da mesma; e 3-Area externa abrangendo os tineamentos entre a periferia da ärea anteriox e os limites do mapa $1 F$ gura $3 A, B \in C$.

Nota-se que a intrusăo, pröpriamente dita, apre senta um padxäo de distribuigäo das frequencias bem dife rente das outras duas areas, embora deva ser considerado, zambëm, o menor nümero de tineamentos por ärea mnitäria. A menox frequência de ineamentos pröximos à direção $E^{\prime}-W$ na parte centrat, com cextera é devida a ausência das dire coes de acamamento on xistosidade, que aparecem nitida mente nos diagramas $B$ e $C$. pox outro lado, a diresäo N-S ressalta, tanto dentro como fora da area alcalina, tevan do a crer que êsse sistema de fraturas seja posterior à atividade magmätica. os picos de frequensia situados, res pectivamente, a NISE e NASE sao caracteristicos do comple so intrusivo.

Näo parece possivet identificar na area $B$ qual quer sistema preferencial, atribuivet a proximidade do magmatismo, uma vez que o padrăo de ineamentos nesta arou $\ddot{e}$ muito semethante ao da area $C$.

Entretanto, analisando os lineamentos nos qua rro quadrantes da ärea próxima à intrusäo, pode-se reconhe cer a influência desta na frequentia das direcöes radiais Figuxa 4\%. Nos quadrantes SE e NW desaparece a predomi nância da xistosidade das encaixantes, tornando-se mais freqtlertes os lineamentos voltados para as rochas alcali nas.

Näo se notou qualquex associagäo da intrusäo alcatina a fraturas ou falhas de grande extensäo. o grande 


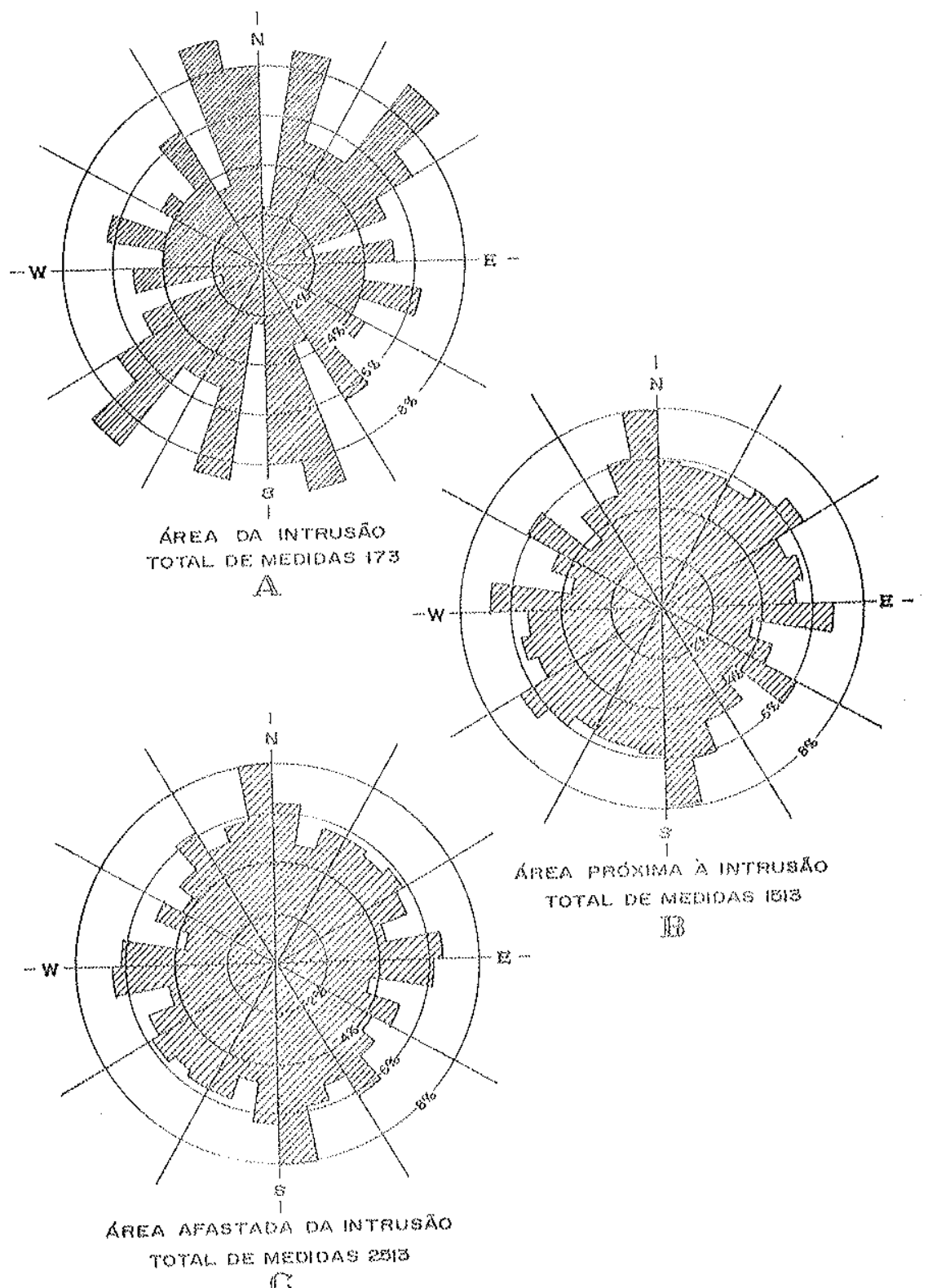

(C)

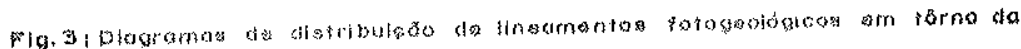
imbrut k̂० alcallna. 


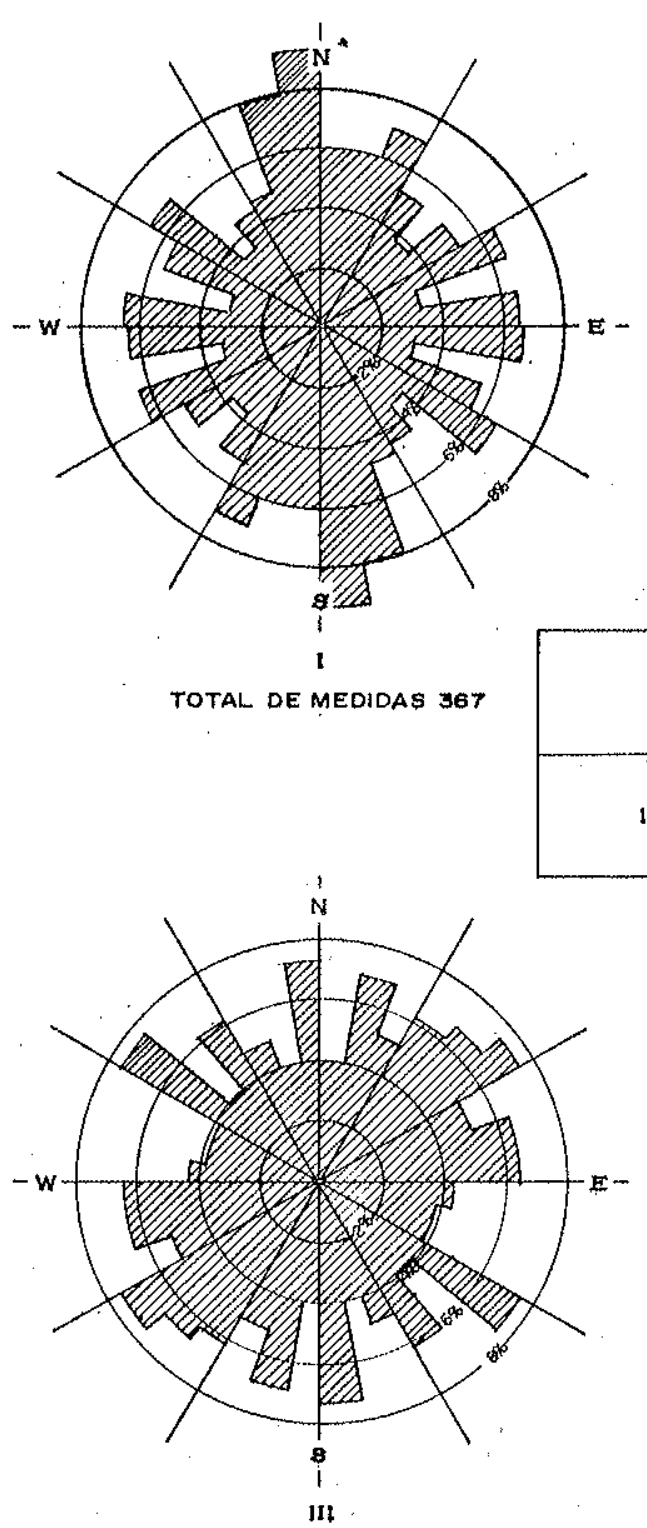

TOTAL DE MEDIDAS 372

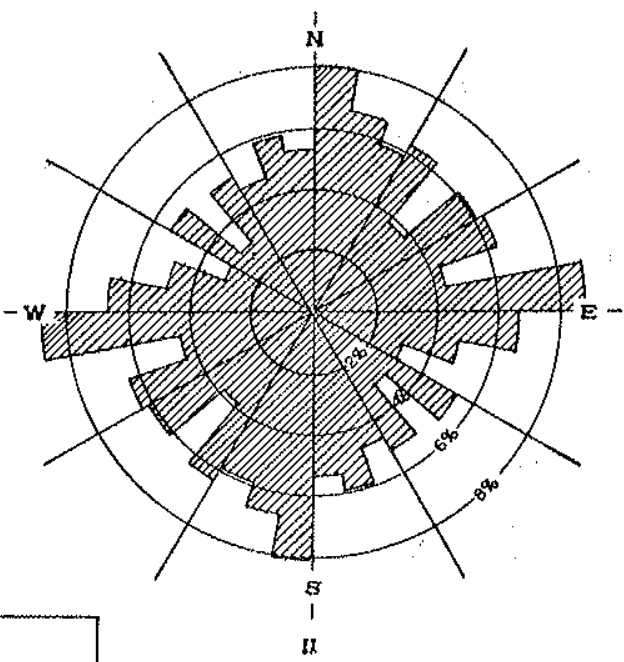

TOTAL DE MEDIDAS 394

IV

Fig. 4: Dlagraman de dlatribuledo de lineamentos totogeoldgicio por quadrantes na drea próxima e intrusbo atoulina 
desnivel existente entre a Serra do Bananal e a Baixada do Ribeira, continuacooes naturais da Serra do Mar e da Baixada Santista, respectivamente, $\vec{e}$ de origem discutida, sendo para alguns consequência da erosão e para outros, pelo menos em parte, devido a falhamentos. Caso o desnivel se ja apenas exosivo, a parte atualmente exposta do complexo alcalino está pelo menos 800 metros abaixo de uma antiga superficie, da qual a serra do Bananal é um vestigio. Melcher (1966, p. 179) em suas consideragões sôbre a intru são de Jacupiranga, situada em altitude pröxima à de Juquiă, admite a possibilidade de mais de 1500 metros de rochas terem sido removidas pela erosăo, incluindo um capeamento do Grupo Agungui pox sedimentos paleozöicos e mesozöicos.

Sömente o estudo tectônico de uma grande região, compreendendo as alcalinas de Jacupiranga, Juquiă, Cananëia e Itapirapuã, poderia trazer eventuais informacões de inte rêsse sôbre as condigöes que controlaram a localizagäo des sas intrusöes.

\section{b) - Petrografia}

Os gnaisses, que circundam a intrusäo alcalina em sua maior parte, apresentam caracteristicas bastante va riäveis. Em parte são gnaisses fitados, com faixas centi mëtricas claras e escuras, encontrados ao longo da $B R-116$. Bem mais frequlentes, no entanto, são os afloramentos onde a rocha apresenta intercalagöes milimëtricas claras e escu ras, muito irregulares e dobradas. Essas rochas podem apre sentar cristais centimëtricos ocasionais de feldspato. Em outros locais a rocha adquire um aspecto granitöide, sem qualquer orientagão nitida dos minerais; essa variedade de encaixante è mais comum a sudoeste da intrusão, onde apre senta coloracão muito clara, quase branca, sendo composta essencialmente por quartzo e feldspato, às vêzes com algu ma biotita.

os minerais mäficos constituintes dos gnaisses säo biotita e anfibótio, concentrados nas bandas escuras. 
A biotita apresenta coloragäo esverdeada a marrom e pleo croismo intenso. 0 anfibölio e uma hornblenda comum, cuja corn varia entre verde e marrom, tamberm bastante pleocröica. As quantidades dêsses minerais säo muito variäveis, podendo existir apenas biotita ou predominar o anfibotio.

Os minerais leucomaticos dos gnaisses sao quartzo, feldspato atcalino e plagioalásio. o quartios, de granutasäo mëdia, ou fina em certas faixas, apresenta con tôrnos denteados e freqllente extincäo ondulante; pode ooox rer como pequenas inclusoes nos feldspatos. o feldspato al oxlino é uma miaroclinio-miarpertitas de aspecto tuxvo geminagão bem nitida. Fxistem dois tipos de plagiooläsio: um muito turvo, frequentemente geminado segundo lei da albi ta, apresentando incipiente transformacăo em epidoto de gra nubagăo muito fina, e cuja composigão mais provävet $\vec{e}$ a da andesina. o outro tipo de plagiocläsio ë limpido, com ge minagá poitissintëtica e ocorre em gräos isolados ou fox mando uma borda em tônno do plagiocläsio turvo; sua composigäo corresponde a oligoelásio-andesina.

outros minerais que ocorvem no gnaisse säo: ala nita de ốr amaxela, milimétriaa, oom borda mais ou menos desenvolvida de epidoto; raxos e pequenos gräos de sircão; apatita como acessörio ocasional e opacos, em quantidade muito restrita.

A composigăo dos gnaisses da regiäo de Juquiä ë bastante semethante $\dot{a}$ das rochas gnaissicas descritas pox Girrardi (1969) na região de Morretes-Antonina, Estado do Paraná. Esse autor admitiu que o metamorfismo regional oor respondeu ao fäcies anfibolitio.

Pröximo do contato WNW da intrusão, ocorre uma pequena faixa de anfibotito, constituido apenas por plagio clásio e hoxnblenda verde, muitas vêzes idiomörfica.

Localmente, as rochas gnäissicas contêm elevada proporcăo de biotita, passando a constituir pequenas zonas melhor caracterizadas como micamisto. Uma dessas wonas, de limitada extensäo, ocorre entre a $B R-116$ e a intrusäo alca 
hina.

Or quartatos que alloxam proxtmo wo Mora do casa de Fedra sao compatos e nao apresentam ortentaga vi

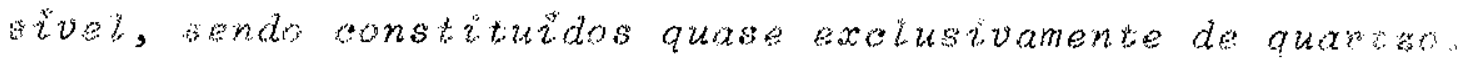

Os dobomitos da Serra do Bananaz sao roohas de

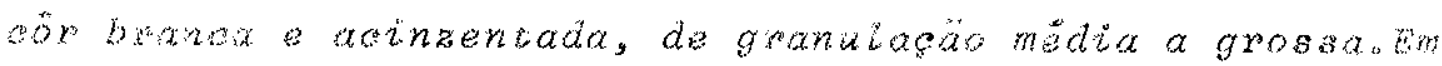

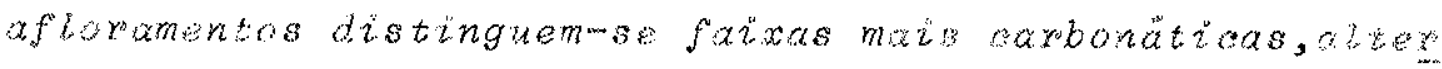
radas sum utras ricas em sittontos. A textura e grande

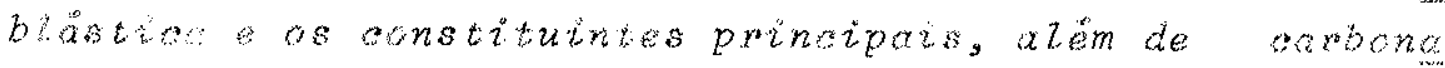
sos, ata diopidio, tremotita o muscovita.

Na proximidade do contato mexidinat da twitu

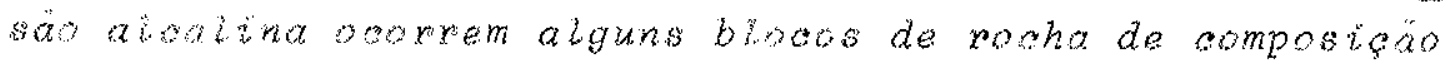

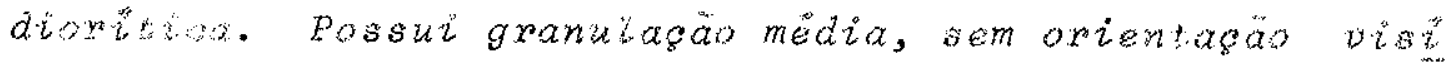

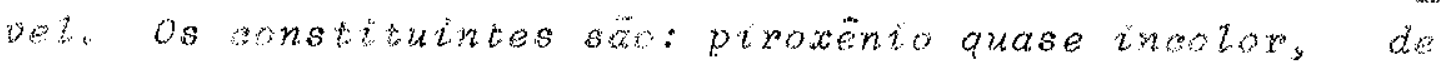

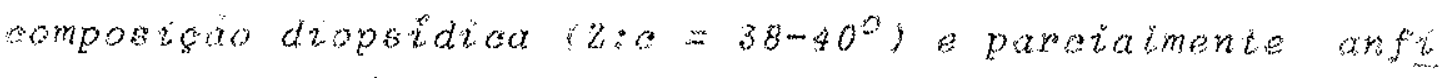

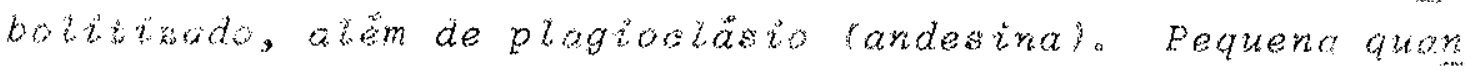

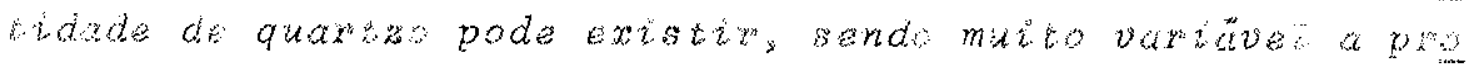
porear de biotita.

\section{3) - Pipentios}

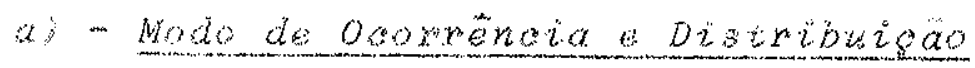

Os piroxenztos oxupam, provavelumente, a mator fragro da sou do comptexo asalino de Juquia, conforme se

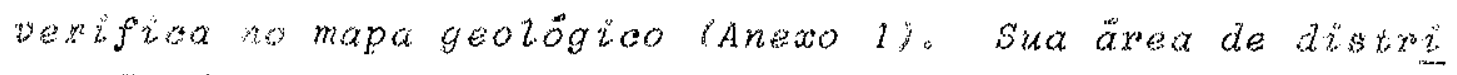

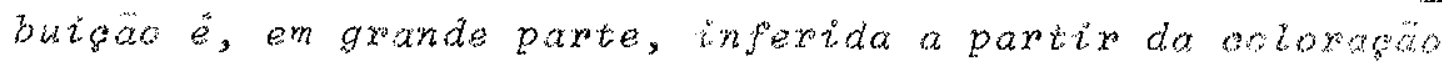
- wermetha intensa dos solos a de reskos do material brigi

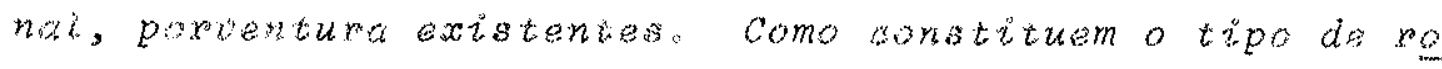

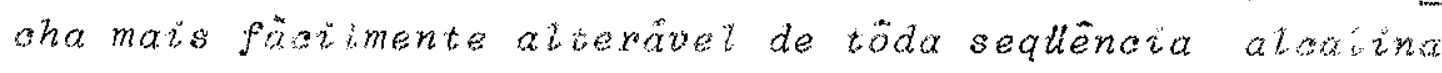
presente em Juquia, explicams sua zedurida odoxienola em blooos ou afloxamentos representativos. Pareoe probivez que grande parte da ärea coberta por brejos e aluriogs re centes esteja tambëm oupada pox xohas dêsse tipo.

Afloramentos de piroxentios foxpm toeatrados 


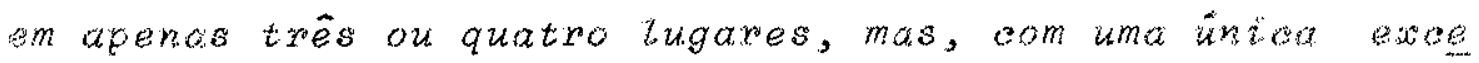

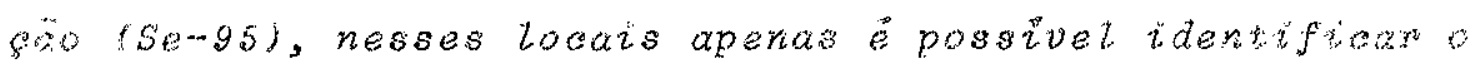
tipo itiologico, rico em minerais mälios. As amostras as thidas foram encontradas gexalmente ras paxtes baixas, pxo wino ao nivel dos brejos, em blowos irregulares de dimen sos decimetricas, soltos ou incrustados em cortes do rego l.t.

As rochas piroxenticas ocupam a parte waskra do womplexo acalino, sendo, por sua vez, oixdundadas apem nas pelos fenitos, na wona de transigäo para os gnatsess

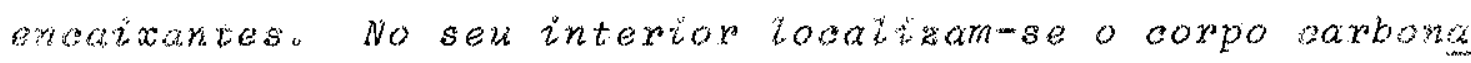

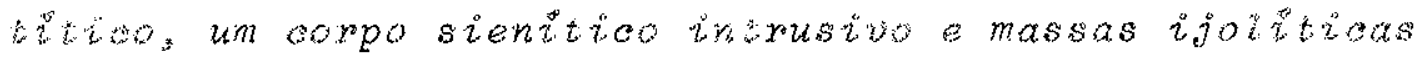
yos stritas. Em divexsos pontos ocortem, tambem, fragments

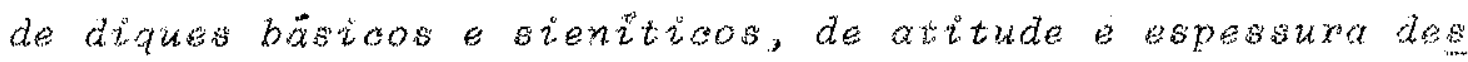
whertation Um aftoramento, representado pela amostra

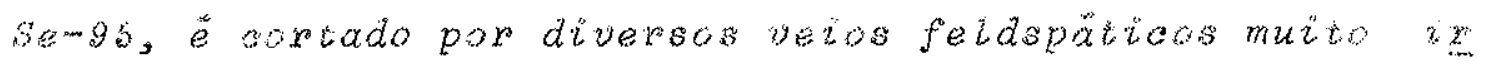
regulares, de espessura inferior a um cersimetro.

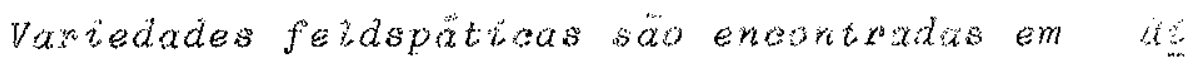

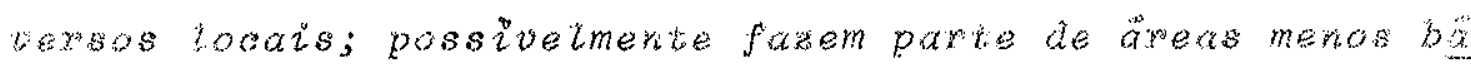

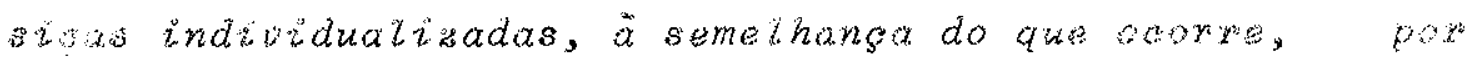

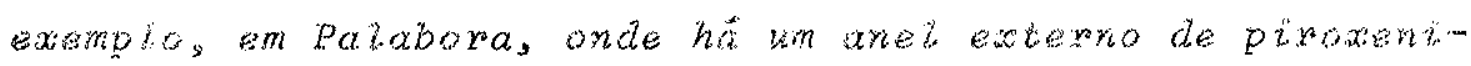

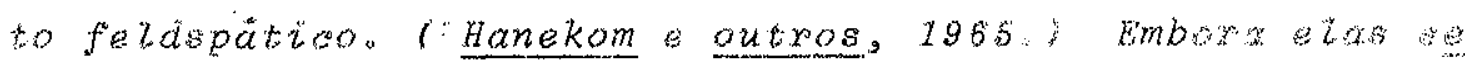
jam encontradas apenas na parte periferisa do somptaxo de

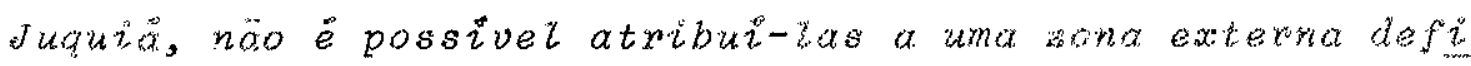
nida, uma ver que se ensontram frequentements wsooiadas a

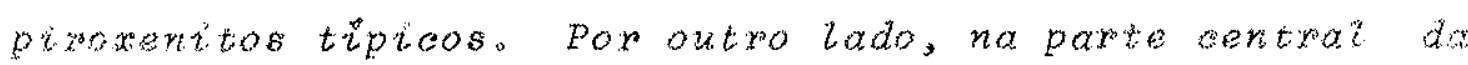
inturasa, falta de afloramentos impossibilita um mopeg nento mats detalhado.

Alguns piroxentitos contêm grande quartidade de otvinx, constituindo termos de passagem paxa peridotutos: :

o intemperismo dos piroxevitos da origem a so Los de coloxacáo vermetha muito intensa, rioss em grăos de

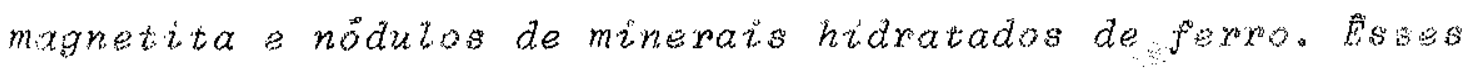

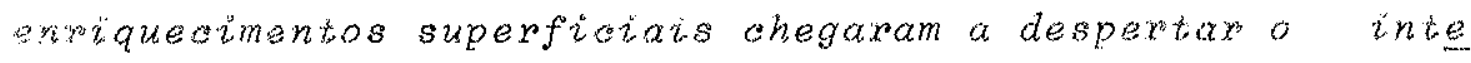

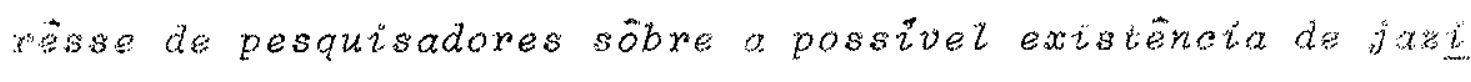


das de minerio de ferro.

\section{b) - Nineralogia}

A composigão mineralogica das roohas ultrabasi cas ë reiativamente simples, caracterizando-se pela predo minância de minerais mäficos, que ultrapassam $50 \%$ em volu me, mesmo nas variedades menos basians; nos casos mais ti. picos, perfazem mais de $80 \%$ dos constituintes, confoxme se pode verificar na Tabela $t$ ( $p .30)$. Os minerais escursos mais importantes são, pela ordem de abundanoia, dinopiro xênio, olivina, biotita e opacos, enquanto entre os mine rais claros predominam os feldspatos, havendo nefetind bordinada. Apatita ë o prineipal acessobio, quase sempre presente, em pequenas quntidades. Serpentina, onotita, sexisita e carbonato sãoprodutos de alteragar dos mine rais essenciais, ocorrendo em quantidades varianeis spaxie do magnetita pode ser proveniente da alteraga ä olityna

\section{prroxencos}

Constituem os minerais mais importantes. ogu pando entro 40 e $80 \%$ em volume; augita $\&$ a variedade pre dominante, alëm de algum hiperstênio ou entstatita. A gra rubaräo varia de 0,2 a $6 \mathrm{~mm}$, situando-se em geval entre y \& $3 \mathrm{~mm}$. A forma dos gräos ë, tambëm, bastante variabel, desde atotriomorfica a prismätian.As formas idiomörfitas paroiamente desenvolvidas podem ser encontradas, com war ta froquéncia, nas variedades mais feldspäticas.

A côr dos piroxénios ä geralmente qastanha, por uses esverdeada. Em läminas delgadas, a colonaga lam bëm ë castanha a esverdeada, porém mais claya. Na maloxia das amostras, o pleocroismo é pouco pronunciado ou mesmo unsente. o piroxenio castanho esverdeado, da amostra se-gs, tem pleocroismo mais visivel, em especial no corte basal. 1001, quando se apresenta marrom claro purpireo em $y$ e 
amarezo esverdeado na sua perpendioular.

os piroxênios comumente exibem zonamento, caras terizado pela existência de faixas ou areas rioas en in clusöes titaniferas, acioulares e oxientadas. Em geral essas faixas estão situadas proximo as boxdas dos graos: Variagoes de coloragão num mesmo oxistal, sugestivas de diferengas na composigäo do mineral, säo rakas; quardo ooorrem, o núcteo é mais claro do que as bordas.

Geminacão simples segundo o plano $\{100\}$ mum, sendo mais rara a ovorrencia de geminagäo polissinte tica, segundo $\{001\}$, em Lamelas bastante largas.

os piroxênios oom muita freqllendia englobam gräos finos de minerais opatos, principalmente magnetita. Quando o piroxênio contém pequenas manchas de bioticka, te se toma descorado e sem inctusós aotoulares om torno da milea.

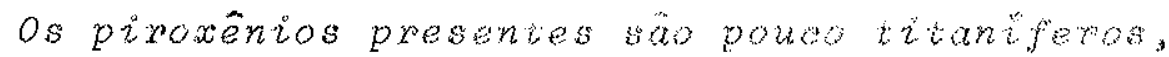

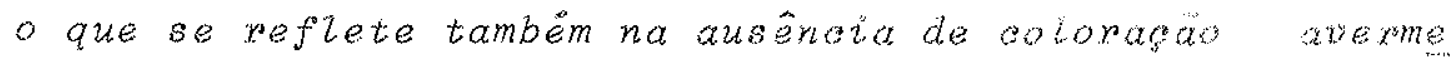
Lhada, oaractexistica muito comum nessan variedades. biste fato também pode ser inferido a partir das analizes qutin axs (Tabela 2), pois apenas a amostra se-9s posal teor de Tro mais elevado, superior a \%.

Algumas rochas contem cerra quantidads de piro xênio ortorrômbico ligeiramente anexmelhado, hipersististo ou enstatita. Esse mineral forma uma auxoola sm borno de cxistais de olivina, tendo-se oxiginado a partix da masma

\section{otivina}

Na maioxia das amostras estudadas, textse uma proporsão variävel de olivina; mesmo em algumas läminas em que estä ausente, airda è possivel notar alanns agrega dos minerais que sugerem sua substituisao. A olivina exi. be cor clara e granulasäo mëdia, entre l e $3 \mathrm{~mm}$, embork gräos finos da ordem de $0,5 \mathrm{~mm}$ năo sejam raros. A olivi na, quando relativamente frequllente, ë alotriombiriod, for. 
mando como que cordões entre os pixoxénios, às vêzes en globando cristais arredondados dêstes. Se, pelo contră rio, ocorre em pequena quantidade, a olivina esta distri buida entre os piroxênios, com forma arredondada, indican do digestão parcial. Em algumas variedades ricas em feldspatos, que envolvem a olivina, esta apresenta formas quase idiomórficas.

Os cristais de olivina quase sempre exibem evi dências de alterasão intempérica, que se faz notar por pe quenos veios de material serpentinico, verde ou amarelado, atravessando os grãos, bem como alguma magnetita secundá ria. fina.

Pequenas inclusões, normalmente de granulação muito fina, constituidas por magnetita e outros minerais não identificados, são comuns e podem estar dispersas ou formando pequenos cordões no mineral.

opticamente, verifica-se que o ângulo $2 \mathrm{~V} \quad \dot{e}$ muito grande, pröximo de $90^{\circ}$, o que indica elevada propor \&ão da molécula forsterita.

Em algumas lâminas foi verificada a existência de um anel de piroxênio, hiperstênio ou enstatita, em tôx no da olivina, formado às suas expensas; na maioria das vêzes, a olivina não mostra qualquer indicio de instabili dade, alèm de sua forma arredondacia.

\section{opacos}

Minerais opacos estão presentes em tôdas as amostras, perfazendo, em gerat, menos de 10\%, embora em rochas muito alteradas possa haver magnetita secundäria, devida à decomposicão de olivina.

os minerais opacos são constituidos quase ex clusivamente por magnetita e, talvez, alguma ilmenita. Em uma üica lâmina foram encontrados abundantes minerais 0 pacos de côr amarela, identificados como pirrotita por se rem magnëticos; em outras amostras a pirrotita ocorre em 
proporgão muito pequena.

A granulagão da magnetita varia de muito fina ate $1,5 \mathrm{~mm}$. Embora seja mais comum entre os minerais fer romagnesianos, quando muito fina, a magnetita consti tui inclusões em outros cristais. Nas variedades mais ri cas em feldspatos pode ocorrer isolada entre gräos dêste mineral.

Uma feigão muito comum ë a presenca de uma co roa de biotita em tôrno da magnetita. Tendência para o idiomorfismo ë bastante rara entre os minerais opacos.

\section{Biotita}

ocorre em quantidades variäveis, atingindo até $15 \%$ do volume total, sendo mais frequlente nas variedades feldspäaticas. E de häbito nitidamente intergranular, apre sentando granulasão entre 0,1 e $2 \mathrm{~mm}$. Como acima mencio nado, muitas vêzes estä associada aos minerais opacos, envolvendo-os parcial ou totalmente.

A biotita $\vec{e}$ de côr muito escura e, do microscö pio, exibe forte pleocroismo, variando segundo X-marrom claro amarelado, $y$-vermeltho escuro e Z-vermetho marrom. parece tratar-se de uma vaxiedade rica em ferro, como in dica o pleocroismo e a associasão aos minerais opacos.

\section{Feldspatos}

Os minerais do grupo dos feldspatos estão au sentes nos piroxenitos mais tipicos, ou ocorrem em quanti dades muito reduzidas; nas amostras menos bäsicas, entre tanto, passam a assumir certa importância, perfazendo at $\vec{e}$ $40 \%$ do volume total.

Quando presentes em pequenas quantidades, os feldspatos preenchem os espacos intergranuzares; nas ro chas em que são abundantes, envolvem os outros minerais. Quando a proporsão de feldspato ë ainda maior, olivina e 
piroxênio passam a apresentar formas quase idiomörficas, em grãos isolados e cercados por feldspatos.

A variedade presente $\ddot{e}$ andesina, que exibe fre qllente geminacão Carlsbad e polissintética, esta segundo a lei da albita e, às vêzes, do periclinio. Em algumas lâmi nas, a andesina pode possuir bordas não geminadas, em tôx no de nücleo com geminacão polissintëtica. Alguns grãos de feldspato alcalino, limpido, podem ser encontrados.

\section{Nefelina}

Em algumas rochas ultrabäsicas podem ocorrer pe quenas quantidades de feldspatoides, representados por ne felina, não ultrapassando alguns pexcento em volume. mineral intersticial e limpido, podendo apresentar peque nas manchas turvas, devidas a alterasão incipiente.

Em uma Linica amostra apareee nefelina intimamen te intercrescida com feldspato, constituindo cordöes, itho tas ou cristais isolados.

\section{Apatita}

E um mineral ocasional, que parece se restrin gix às variedades feldspäticas, representado por grãos lím pidos de häbito pxismätico e de granulasão fina.

Perovskita

A perovskita ocorre como mineral ocasional de uma ou outra rocha e, mesmo onde ë mais freqllente, ocupa menos de 1\%. Apresenta granulagão fina a muito fina, em geral menor do que $0,1 \mathrm{~mm}$. A perovskita esta associada aos minerais opacos, podendo formar uma coroa parcial em volta dêles. Em lâmina, sua côx ë avermelhada, com ligei ra tonalidade marrom; sua observacão $\ddot{e}$ mais fäcil com luz convergente, pois a perovskita, alëm de ser fina, muitas vêzes ocorre entre grãos de minerais opacos. 


\section{c) - Petrografia}

As rochas aqui designadas, genèricamente, como piroxenitos englobam uma sêrie de variedades nas quais os minerais mäficos, piroxênio e olivina, predominam de ma neira acentuada, mas compreendem tambëm tipos menos bäsi cos, contendo feldspatos. Algumas vêzes säo tambëm desig nadas rochas ultrabasicas, mas apenas no sentido de que, em conjunto, säo pobres em sïlica.

os piroxenitos säo de tonalidade muito escura, geralmente sem estruturas evidentes. A suborientasão de piroxenios, restrita a poucas amostras, pode ser reconhe cida em fraturas frescas. Entre os minerais, apenas os piroxênios maiores podem ser identificados à vista desar mada, quando mostram faces de clivagem distintas. Nas amostras que possuem uma crosta intemperizada, os cris tais de piroxênio se tornam salientes por serem um pouco mais estäveis; as variedades feldspäticas, pox sua vez, podem ser reconheoidas, pois os feldspatos em alteragão adquirem côr esbranquisada. os piroxenitos muito altera dos tornam-se bastante friäveis e esverdeados, podendo exibir aspecto xistoso.

Em geral, as rochas possuem textura hipidiomóx fica granular, nas quais o piroxênio e a olivina podem apresentar tendência a desenvolver formas próprias; jă a biotita, feldspato e nefelina, quando presentes, säo in tersticiais. A ordem de cristalizagão dos minerais è mag netita, olivina e piroxênio mais ou menos contemporâneos, biotita, feldspato e nefelina.

A granulagão dos minerais constituintes varia de fina a média, não havendo amostras de granulasão exclu sivamente fina. o material fino ocorre em manchas ou entre grãos maiores, sendo constituido, principalmente,por piroxênio e otivina.

A Tabela 1 mostra a composigäo modal de 7 amos tras dêste grupo, ordenadas dos têemos mais bäsicos para 
os menos bäsicos.

Não é possivel dizer quais as variedades que predo minam no campo, uma vez que, como jä foi frizado, o nümero de amostras é pequeno em relagão à ärea; além disso, a maioria de las foi colhida em locais onde ocorrem concentracones de blocos semi-alterados, que possivelmente representam poreões mais re sistentes ao intemperismo. Os dois ou três afloramentos "in situ" dessas rochas, abaixo do solo vermetho, encontram-se por demais alterados para permitir estudo ou amostragem.

$$
S e-95 \quad s e-27 \quad p-23 \quad s e-31 * S e-104 \quad s e-75 \quad p-18
$$

\begin{tabular}{|c|c|c|c|c|c|c|c|}
\hline piroxênio & 81,5 & 60 & 57 & 49 & 55,5 & 46 & 42 \\
\hline orivina & - & 33,5 & 24 & 19,5 & - & 23 & 3,5 \\
\hline Biotita & 6 & 1,5 & 0,5 & 12 & 13 & 8 & 9,5 \\
\hline plagioclásio & - & - & 7 & - & 13,5 & & \\
\hline rezdsp.K K & - & - & - & & - & 1 & \\
\hline Nefelina & 3 & - & - & & - & - & - \\
\hline opacos & 8,5 & 2,5 & 9,5 & 2,5 & 16 & 6 & $5 *$ \\
\hline Apatita & tr & - & 0,5 & 1 & 1 & $t r$ & 0,5 \\
\hline Perovskita & 0,5 & - & - & - & - & - & - \\
\hline Carbonatos & - & 0,5 & - & - & - & - & - \\
\hline Serpentina & $t r$ & 2,5 & 1 & 1,5 & 1,5 & 3 & 2 \\
\hline outros & - & $t r$ & $t r$ & - & - & - & - \\
\hline
\end{tabular}

(*) inclui sulfetos

Tabela 1: Composigão modal de algumas rochas ultrabasicas da intrusão alealina de Juquia. 
As amostras Se-Z7 e P-23 säo maeroscópicamente semelhantes e provenientes do mesmo local, no entanto, mos tram consideräveis diferengas na composigäo. pelo fato de se apresentarem pouco alteradas, apesar de provenientes de pequenos blocos e constituidas por minerais bastante sus ceptiveis ao intemperismo, pode-se admitir que elas sejam representativas dessa ärea.

As variedades pobres ou isentas de feldspatos, mas com quantidades consideräveis de olivina, como por exemplo as amostras se-27 e p-23, constituem têrmos inter mediărios entre piroxenitos e peridotitos.

A amostra se-9s referida na Tabela 1 ëprovãvel mente, a que mais se aproxima de um jacupiranguito tipico, segundo definido por Johannsen (1938), pois contëm 9o\% de augita e opacos. Entre os minerais restantes, a biotita ë - mais importante, o que permite classificar a rocha como biotita jacupiranguito ou bebedourito, segundo definigäo do mesmo autor. o piroxentio exibe häbito prismitico aion gado, sendo o comprimento de 4 a 5 vêzes a largura do mine ral; näo ha orientacão dos piroxentios, apesar de ocorrer paralelismo de varios cristais. Grande parte da biotita vermetha intergranular esta associada aos minerais opacos, podendo tambëm englobar pequenos gräos de piroxento. Dessa amostra ocorre, ainda, pequena quantidade de nefelino in tergranular e pouca perovskita. Em lamina notam-se al guns veios delgados preenchidos por carbonatos; nos contatos com êsses veios o pixoxênio adquire oón esverdeada.

- As outras variedades possuem entre $10 \mathrm{e} 40 \%$ de fezaspatos, o que as caractexial como gabros alcalinos. pi roxênio, com zonamento desenvolvido, e olivina apresentam certa tendência ao idiomorfismo, caracteristica que se tor na mais acentuada com aumenio da quantidade de feldspatos. A biotita, tambëm associada aos opacos, ë mais frequlente do que nos piroxenitos pröpriamente ditos.

A amostra se-31 contëm $14 \%$ de minerais alaros, sendo $3-4 \%$ de nefelina e o restante feldspato potissico. Esses dois constituintes, interstraiais e tardios, encon 
tram-se intimamente associados, sendo comuns grãos de felds pato contendo grânulos de nefelina.

o feldspato predominante das amostras se-75 e $p-18 \dot{e}$ andesina, que pode ser zonada, ao lado de quantidade muito pequena de feidspato alcalino. Além disso, essas duas amostras têm. certa quantidade de ortopiroxênio, mais co mum em $P-18$, constituindo boxda de alteracão de olivina.

No complexo alcalino não foram encontrados peri dotitos tipicos em afloramentos. Entretanto, a presença dês se tipo de rocha $\dot{e}$ demonstrada por alguns blocos intensamen te serpentinizados, em que são reconheciveis numerosos res tos de olivina, alèm de algumas manchas ricas em pixoxênio. A constituigão modal aproximada $\vec{e}$ a seguinte: $25 \%$ de olivi na, $2,5 \%$ de piroxênio, $54 \%$ de serpentina e $18 \%$ de opacos, predominando a magnetita.

Na Tabela 2 é apresentada a composicão quimica de dois piroxenitos de Juquiä, juntamente com mëdias de ana lises de localidades congêneres.

Verifica-se que a composicão da amostra $S e-95$ di fere um pouco dos valores mëdios de 21 amostras, determina dos por Nockolds (1954), por possuir $\mathrm{Al}_{2} \mathrm{O}_{3}$ e MgO baixos e Fe $_{2}{ }_{3}$ e CaO mais altos. Em relagão ao jacupiranguito da lo calidade original, a rocha de Juquiä se destaca, especialmen te por teores de $\mathrm{Fe}_{2} \mathrm{O}_{3} \mathrm{e} \mathrm{TiO}_{2}$ mais baixos e de älcalis bem mais elevados; isto $\vec{e}$ devido, principalmente, $\ddot{a}$ presensa de biotita e de alguma nefelina. Deve-se notar, no entanto, que os piroxenitos de Jacupiranga têm composicão mineralógi ca variävel, podendo existir quantidades substanciais de bio tita e nefelina. A amostra de Jacupiranga, que Washington considerou tipica daquela localidade, recebeu a denominasão jacupiranguito, devido à composicão diversa dos piroxenitos atê então descritos. 


$$
\operatorname{Se}-95
$$

$$
5 e-25
$$

$A$

$B$

\begin{tabular}{|c|c|c|c|c|c|}
\hline $\mathrm{SiO}_{2}$ & 42,20 & 41.70 & 38,38 & 41,55 & 40,27 \\
\hline $\mathrm{PiO}_{2}$ & 2,36 & 1,36 & 4,32 & 3,32 & $i, 30$ \\
\hline $\mathrm{Al}_{2} \mathrm{O}_{3}$ & 6,58 & 6,58 & $8_{3}^{0} .15$ & $7: 25$ & 7.29 \\
\hline $\mathrm{Fe}_{2} \mathrm{O}_{3}$ & 7.69 & 5.44 & $1 \%, 70$ & 6,80 & $4: 8$ \\
\hline$E^{\prime} e 0$ & 7,82 & 9,62 & 8.24 & 7.77 & $9_{13} 08$ \\
\hline MnO & 0,03 & 0.15 & $0.76^{\circ}$ & 0.20 & 0.25 \\
\hline$M g O$ & 11,79 & 19,74 & $x I_{3} 47$ & 13,02 & 24.37 \\
\hline CaO & 17.56 & $1 y_{s} 66^{\circ}$ & 28.60 & 26.93 & $y_{s}, \quad .5$ \\
\hline $\mathrm{Na}_{2} \mathrm{O}$ & 1,76 & 3.68 & 0,78 & 1,38 & $x_{3} 06^{\circ}$ \\
\hline$K_{2} 0$ & 1.01 & 0.04 & 0,13 & 0.70 & 0.62 \\
\hline${ }_{2}{ }^{O+}$ & - & - & 0,54 & 0,50 & 3.67 \\
\hline $\mathrm{H}_{2} \mathrm{O}^{\mathrm{O}}$ & 0,14 & 0,24 & 0.18 & $\infty$ & $\cdots$ \\
\hline$P_{2} O_{5}$ & 0,15 & 0.03 & 0.27 & 0,59 & 0,38 \\
\hline \multirow[t]{2}{*}{$\mathrm{CO}_{2}$} & 0,29 & 0,18 & $=\infty$ & $\infty$ & 0.34 \\
\hline & 98,44 & $700_{8} 42$ & 700.72 & 100,00 & 700,00 \\
\hline
\end{tabular}

$c$

\footnotetext{
Sem 95 Biotita piroxenito (Bebedouritol - Proximo a base do Morro do serrotes lado norte suquia.

Se-25 Piroxenito parte noxte do complexo alealino Juquiä。

A Jacupixanguito * Jacupiranga - Washington 12901; em Johannsen (1938).

B - Alcaliwiroxenito Média de 21 aralises Nockolds (1954).

C Alcali-peridotito Mêdia de 12 analises Nockolds $(2954)$.
}

Tabela 2: Composigao quimica de rochas piroxenitions. 
A amostra Se-25 ê bastarte semethartie a bew 27 ouja composifão modal consta da mabelat, sendo. wo artan to mais pobre em olivina. sua andise quimisa binfirma tratarme de uma variedade intermediaria entre pixoxutros e peridotitos, distinguindowe das analises apresentadas para comparasaos pela pobreza em $\mathrm{Al}_{2} \mathrm{O}_{3}$ e FeO als principalmente, pelo elevado teor em $\mathrm{Na}, \mathrm{O}_{3}$ ao lado de $\mathrm{K}_{2}$ ? muito baixo.

$5 e-95$

or

$A b$

An

Ne

Le

Ac

$D i \quad\left\{\begin{array}{l}W O \\ E n \\ F\end{array}\right.$

Cs

$01 \quad\left\{\begin{array}{l}F_{0} \\ F a\end{array}\right.$

$\mathrm{Cc}$

$A p$

II

$M t$
7,29

9,77

4,92

26,84

24,16

2,68

$3 ; 76$

7,04

0,78

0,76

0,32

3,39

8,29
$S e^{\cos } 25$

1,9 a

19.09

0,28

19,03

70,82

$7.8 \%$

$4,6 ?$

24,48

7,43

0,94

0,06

2.82

5.98

Crpw modifo Niggli (segoBarth, 1952)

Tabeta 2a: Normas moteculares de duas roohas piroxenitioas de Juquïa. 


\section{a) - Ijolitos}

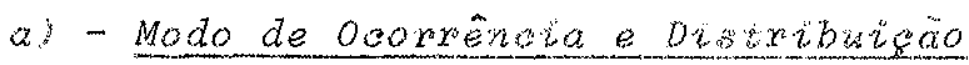

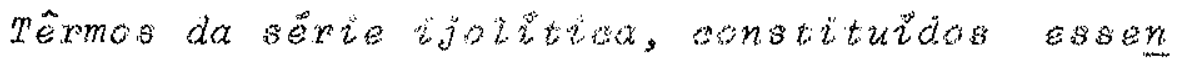
aramente pox piroxênios e feldagabides em quaritiades va riäveis, foram enoontrados em quario lowa diferentes, po

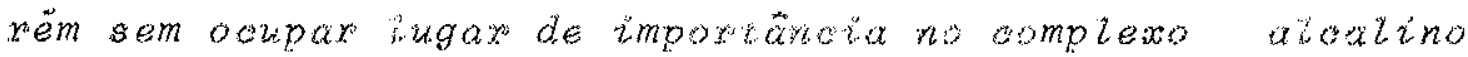
de Juquid. Essas exposises sos de area westrita, sendo representadas por $3-4$ blowo, oujas dimensoes raramerte ut trapassam $7-i, 5$ m. Pox êse motivo noo foi postivel esta

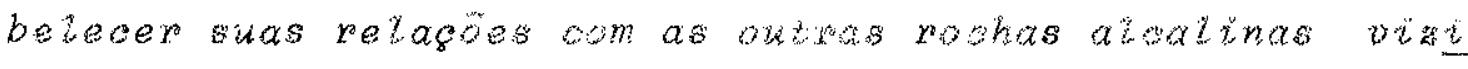

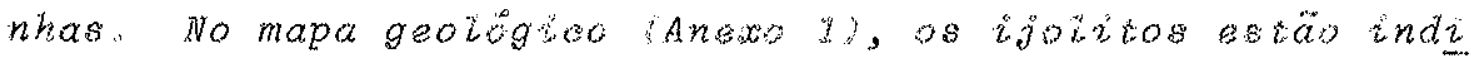
wados apense nos tookts sm que aftoram, embora possam ow par area mats ampla. Dots aftzramentos distatos no lado owste dx base do Morro do serrote, estä indirados como

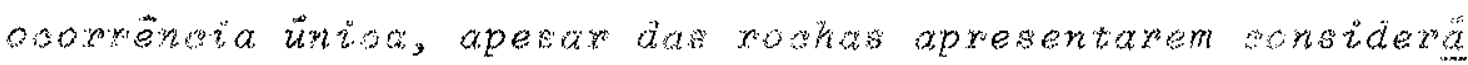
weis diferengas na composigar.

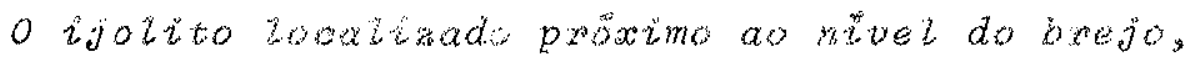
na parte sudeste da base do Moxro do senwote, provavelmen

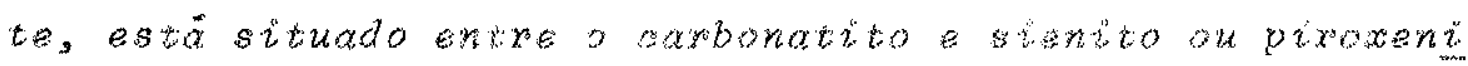

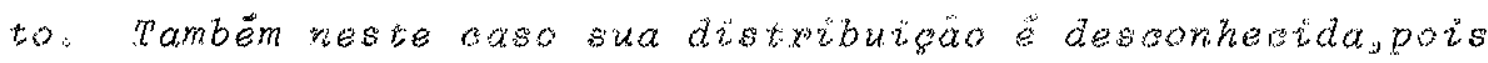

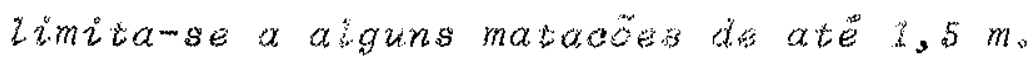

No Guaviruva, esta varedade ororre em meito a numerosos afloxomentos de sorvito e o pequeno numero de blo oss sugere distribuigao restrita Manchas ijotiticas escu ras foram encontradas em uma xooha mutio feldspatisada, que apressua, inczusive, gräos awedondados de refelina, en vozvidos por feldspato. Es modo de ocoxientia sugers que os ijolitos tenham sido parcialmente feldspatizados, dando origem a sienitos.

As rochas dêste gripo que aftoram na base do Morro do serrote jä haviam sido tivadas por Knecht e telioissime fr. (1939), que as descrevexam romo diques em con tato com calario dolomitioo, provententes da diferencia sao do magma sienitico. As condicoes atuais de exposifán, 
entretanto, não permitem determinar as relacós de campo com seguranga.

\section{b) - Mineralogia}

Os ijolitos eompöem-se ssongiamente de piro xênio e fetdrpatordes, embora algumas variedades possuam quantidades elevadas de biotato. Titantia, opaoss, carbo natos e apatita, constituem os asessotios mats omins sen do mais impoxtantes os dous primeixos. Pexovskita pode worer am algumas amostyas, oomo nusteos avexmelhados em

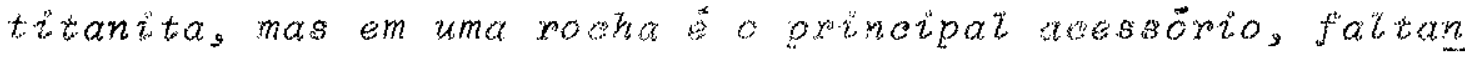
do a tizanis

\section{Pixoxentoss}

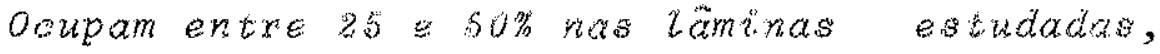
embora, em pêso, sua propoxso aumente um pouso, devido a

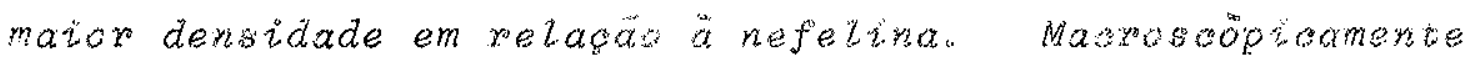

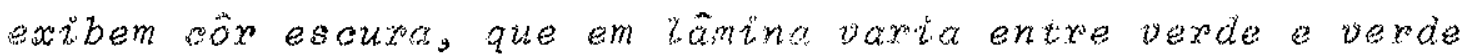

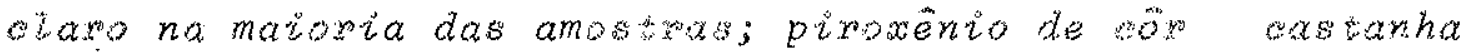
esyerdeada for encontyado em aperas uma lamina. Alguns pi roxentos salo quase incoloxss, mas em gexal este fate se pestringe do riuleo dos chistais.

o piroxênio verde. egurina-augitioo, sem düvi

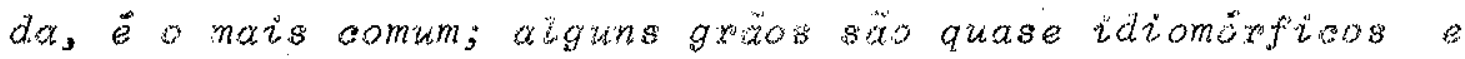

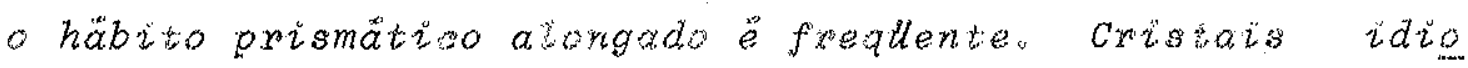
morficos finos de puroxertio oporsem como pequenas inciu söes em nefelina, biotita a as weses titaniba, que as en volvem poiquizititamente. os gränüos mats fints terdem a apresentar cantos arredondados.

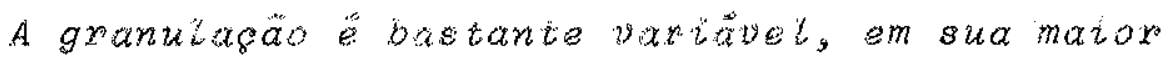

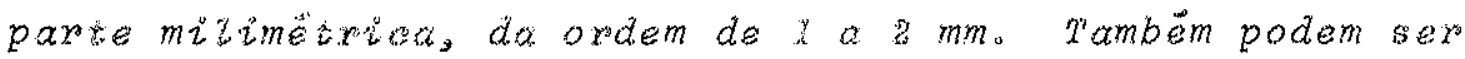
enconsrados alguns grăos de prooxentio de th a $5 \mathrm{~mm}$. Em dex tas laminas, entretanso, observamse micro-ijolitos com gra nutasão predominante de 0,1 a $0,3 \mathrm{~mm}$. 
Nos piroxênios verdes o zonamento é muito fre qllente, caracterizando-se pela presenga de nucleos alaros ou quase incolores, de composigäo augitica, enquanto as bordas são verdes, mais ricas no molëcula egirina o pleocroismo, nos piroxênios verdes mais somuns, $\vec{e}$ fraco a moderado e apre senta a seguinte variagão: X - verde, $X$ - verde claro, $Z$ amarelo esverdeado. Os nücleos de piroxenio quase incolor em alguns casos contêm pequenas inelusöes aciculares orievia das, provàvelmente de um mineral titanifero. Essas inclu söes são semelhantes àquelas encontradas nas rochas prixoxen ticas.

o piroxênio augitico da amostra se-lo3, no entan to, $\vec{e}$ muito diferente, tanto pelo habito, acentuadamente pris mätico e alongado, como pela tendência ao idiomorfismo. Além disso, êsses piroxênios estão suborientados, constivitrido prismas atongados de 1 a $4 \mathrm{~mm}$ de comprimentos enquanto a ias gura mäxima atinge $0,7 \mathrm{~mm}$ nos dristais maiores. Seu pleocro ismo tambëm ë fraco, nas tonalidades $X$-castanho, Y-castanho avermethado, e z-castanho amarelado. o zonamento, quando 0 corre, ë inverso dos piroxênios acima descritos, pois as bor das apresentam cor a astanha roxmal, enquanto os nücleos são de coloragão verde. Localmente, ocorrem inclusöes aviula res orientadas, dispersas ou constituindo manchas restritas e pouco densas.

Os piroxênios verdes de granulagäo maior podem englobar nefelina, titanita e apatita, alëm de esquilulas de biotita e minerais opacos, às vêzes em grande quantidade. 0 piroxênio castanho, por sua vez, engloba grande nümero de grãos finos (atë $0,1 \mathrm{~mm}$ ) de perovskita, de opacos e poucos de nefelina.

Nas proximidades de veios sieniticos, que cortam os ijolitos, o piroxênio adquire coloragâo verde-garrafa, ti pica de egirina; quando os piroxêriios são englobados por mi nerais dêsses veios, podem ser transformados em melanita, de côr amarela e alto relèvo, encontrada apenas em casos muito raros. 
Feldspatöides

são constituidos essencialmente por nefelina, que em lâmina se apresenta normalmente limpida, pousas vê zes com formato quase retangular.

Sua granulacão é bastante variävet, pois em al guns casos a dimensäo mais comum situa-se entre 1 e $3 \mathrm{~mm}$, enquanto em rochas de granulagão fina predominam diametros entre 0,2 e $0,4 \mathrm{~mm}$. Mesmo nas amostxas onde predomina ne felina milimëtrica encontram-se manchas constituidas por grãos finos. Em um ünico caso a nefelina preenche espagos entre os outros minerais, ocupando apenas cerca de $15 \%$ do volume total. Nas outras variedades sua percentagem é maior, oscilando entre 30 e $60 \%$ do total.

A nefelina posaui inumeras inoinsobs muito fi nas, näo identificaveis, que se distribuem em ordoos aion gados, ao longo de planos preferenciais ou de maneira de soxderada. Essas inclusoes podem sex agulhas finissimas, parcialmente orientadas, podendo tratar-se, tamberm, de in clusöes liquidas ou gasosas.

Com bastante freqliènaía os cristais maiores de nefelina contêm inclusoes de piroxenio verds, ocicular ou em pequenos grânulos. Nas pouens amostras com perovskita, a nefelina tambèm engloba êsse minexal.

Alguns sinais de alteragão sempre podem ser no tados na nefelinas sua intensidade varia desde incipiente, ao longo de fraturas, até formar pequenas manchas de mine rais securdärios. Estes são constituidos principalmente por cancrinita, que se destaca por sua côr de interferên cia amarela, alëm de caleita.

\section{Biotita}

A biotita apareos em quase tödas rochas ijoli ticas, em propoxsäo pequena a mëdia; em casos excepoionais pode ser mais abundante do que a nefelina. De preferência 


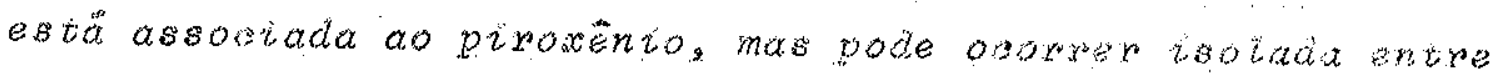

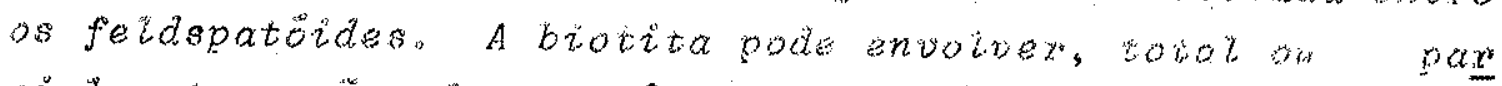

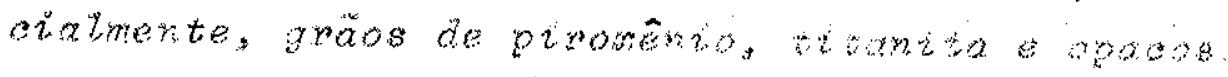

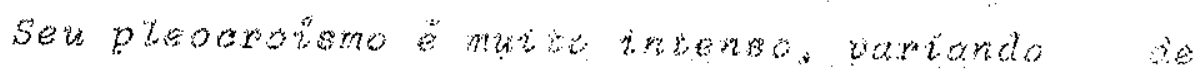

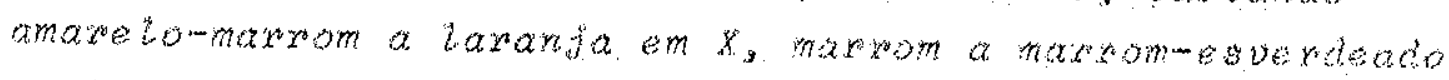

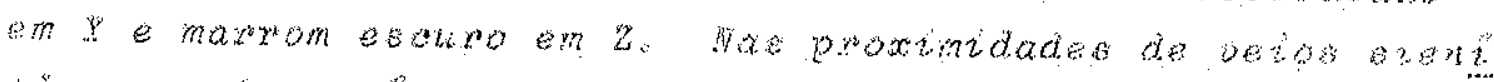

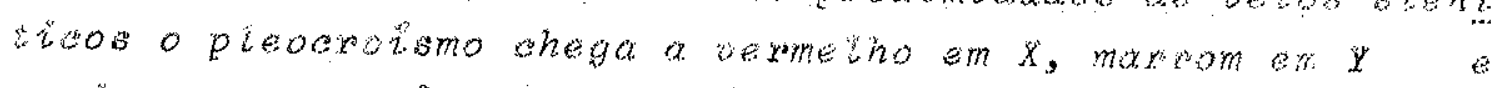

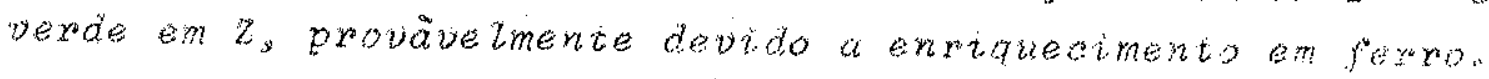

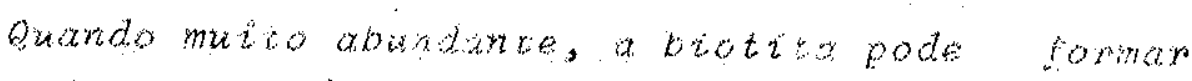

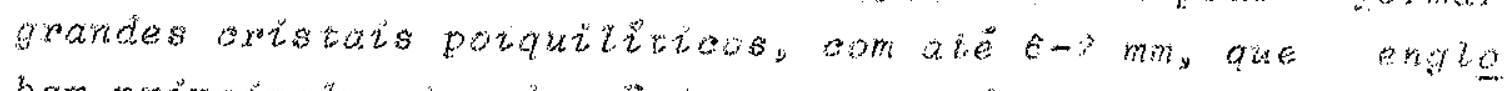
bam primatpalmente piroxento, nas rambem nejeline, opaoos perosisterto

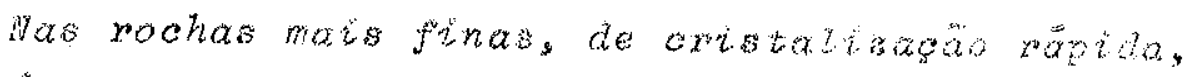

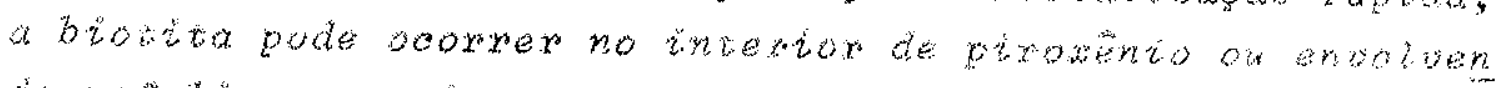
do nefelina em nator quantidode.

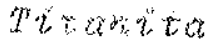

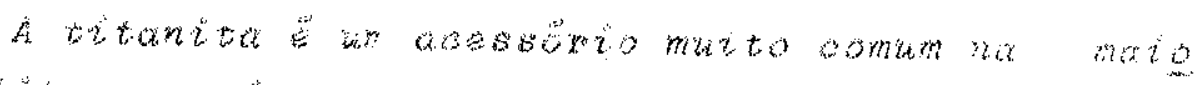

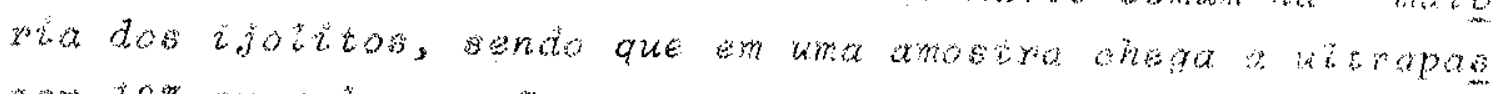

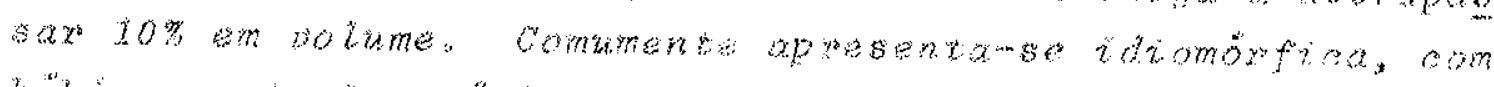

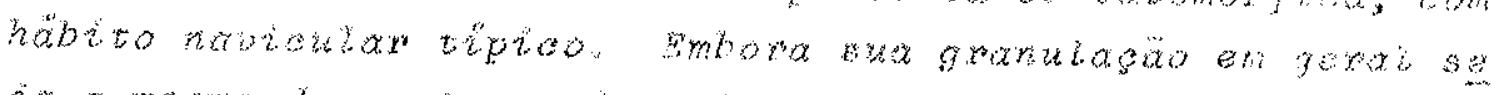

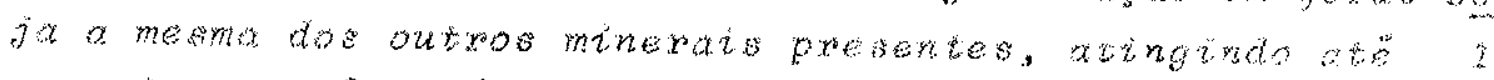

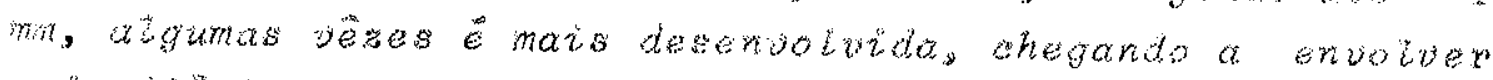

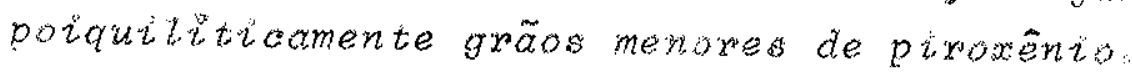

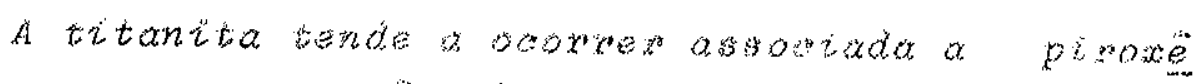

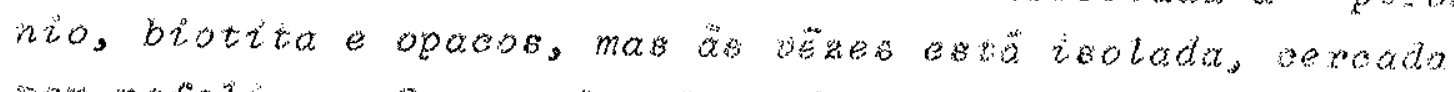

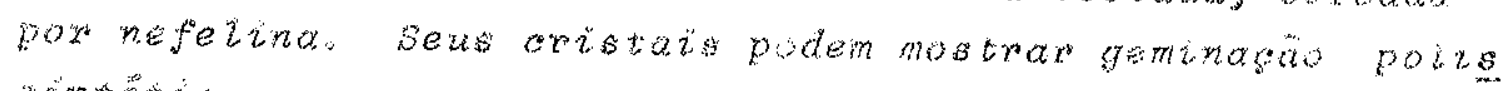
antertod.

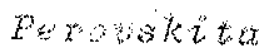

A pexovskita näo partionpa da ounititulato nor

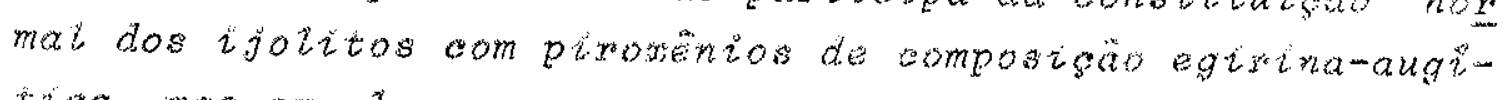

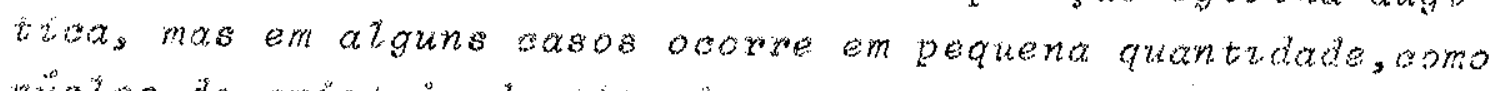

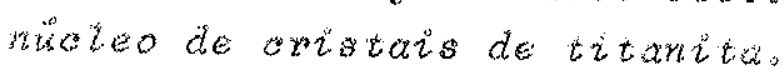


Na amostra se-103, entretanto, a perovskita $\ddot{e}$ bas tante freqliente e numerosos grãos tendem ao idiomorfismo, com contornos retangulares ou quadrados. Nessa amostra, o minerat ocorre em Iugar de titanita, que falta por completo. Constitui inclusão em todos os minerais, exceto os opacos, em tôrno dos quais pode formar uma boxda mais ou menos fi na. A perovskita exibe sor violeta a marrom muito esauro, tornando-se amaretada nas bordas mais finas; sua birrefrin gêncra è muito baixa. Em seu interior apresenta muitas in clusöes finas näo identifiuadas, bem como geminagäo polis sintëtica ocasional.

Apatita

Eum acessoorio basiante comum em algumas amos tras, embora falte em outras. Wuitas vêzes ocorre na forma de grãos prismatioos ou arredondados que, em lâmina, estäo isolados ou associados em pequends manchas. suas dimensoes, em geral, não atingem $0,5 \mathrm{~mm}$, embora alguns aristais prismâ ticos possam ter até $1 \mathrm{~mm}$ de comprimento.

\section{opacos}

Säo minerais acessobios sempre presentes, ocoxien do dispersos e em quantidade sariavel; äs vêses sâo yaros, mas podem perfazer ate $5 \%$ do total. são constituidos por magnetita e pirrotita. A primeira apresenta-se em gräos alotriomórficos entre os outros minerais, enquanto a pirro tita ë tardia e as vêeses ocupa espagos intersticiais entre os piroxênios. A granulagão dos minerais opacos é fina, ra ramente uttrapassando i $\mathrm{mm}$.

Carbonatos

Nos ijolitos, algumas vêses ocorrem manchas de calcita intersticial, com atê $1 \mathrm{~mm}$ de diametro. A grande maioria dos carbonatos, no entanto, ¿̇ miito fina, sendo pro duto de alteragão de nefeirna, na qual forma pequenas man 
whas ou preerche fraturas, assooiandome a cancrintta.

c) Petrografia

As rochas ijolizreas eompreendem aqui tôda a sërie uxtito-ijotito-melteigito, definida por Brbggex (1.921), uti Lizando-se essa designasao para agrupas tödas as variedades compostas essencialmente pox piroxento e feldspatöides. os limites de subdiviscio dessa series de acôrdo com a propop são de feldspatöides, são os adotados pox dohannsen 11938 , p. 313; de $0-50,50-70$ e $70-100 \%$, respectivamente, para melteigitio, ijolito e urtituo

săo xoshas escuxas, que se tornam mais claras a me dida que aumenta a quantidade de feldspatöides. podem apre sentax manshas muito escuras a de dimensóes restritas, que têm biotita como principat constituinte. A maioria dos ijo litos estat coxtada por veios fetdspoticos ou sientitcos, ota ros e irregulares, cuja espessuxa varta de poucos milime tros a mats de $10 \mathrm{~cm}$, às verses com aspecto pegmativioo. As rochas não mostram qualquex oxientasäo dos minexais. A ne felina forma manchas brancas, quando ocorre em agregados ou cristais maiores, äs vezes idiomórfocos. Cristais milimé tricos de piroxênio säo reoonheorveis a otho nu devido à sua oltwagem, enquanto a biotita se caractemisa pelas pathe tas factimente destacavers. Nos ijotitos de granubasao fi na nenhum desses minerais ê identipicavel.

A maior parte das amostras apresenta textura hipi diomörica granuiar, sendo pirocentio e nefelina os minerais que podem exibir idzomorfismo, alem dos acessórios. Algumas variedades, no entanto, mostram textura alotriomórfica. A granulaeä é bastante variâvel, predominondo os têmos mé dios a finos; algumas vêzes ovorxen grâs de piroxênio e ne felina de granulacäo marox. cristais de nefelina, com fa aes parcialmente desenvolvidas, podem constituix associacoes glomexopoxfiritreas. Em varias amosixas, a biotita é um constituinte de impoxtarick. Alguns ijolitos possuem grâ

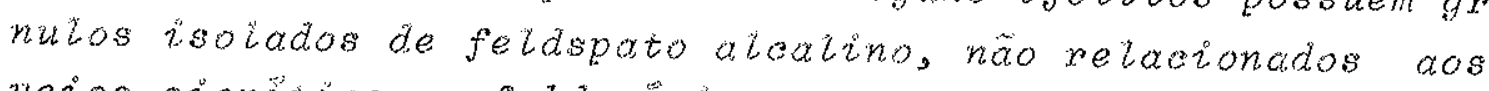
veios sieniticos e feldspatioos que cortam a rocha. 


$$
5 e-50 * \quad s e-111 \quad \text { se }-53 \quad s e-103^{*}
$$

\begin{tabular}{|c|c|c|c|c|}
\hline Nefelina & 61 & 53,5 & 29,5 & 14,5 \\
\hline Piroxênio & 26,5 & 42 & 34,5 & 44 \\
\hline Biotita & 6,5 & 0,6 & 34,5 & 30 \\
\hline Opacos & $t x^{\prime}$ & $\ddot{L}$ & $t x_{0}$ & 5 \\
\hline Titanita & 1,5 & 2,5 & $x, 5$ & - \\
\hline Feldspato & 1,5 & J. & - & - \\
\hline Carbonatos & 1 & - & - & - \\
\hline Apatita & 0,5 & - & - & 2 \\
\hline Perouskita & - & - & $t r$ & 4 \\
\hline $\begin{array}{l}\text { outros (inol. } \\
\text { canorinito) }\end{array}$ & 1,5 & - & - & - \\
\hline
\end{tabular}

(*) Anäise quimica na trabela 4.

Tabela 3: Composizaio modal de algumas rochas ijolitioas de suquia.

A composigão modal de algumas amostras consta da ta bela 3. Verifica-se que sem 50 e se-111 são verdadeiros ijo litos, enquanto se-53 e se-703 podem sex designadas biotita meltergitos, pela elevada proporeão de biotita.

- piroxentio da maioria das rochas ijoliticas de du quiä ë eginina-augita. Constitui excecão a amostra se-1.03, cujo piroxentio é de composigão augitica, indicando afinía des com os piroxenitios.

As amostras se-50 e Se-53, provenientes de locais muito pröximos no mesmo afloramento, indicam que a composi căo pode sex muito variävel. Neste caso, em menos de um me 
tro, uma rocha muito rica em feldspatoides passa para outra variedade, onde os minerais máficos perfazem präticamente o dobro dos feldspatoides; destaca-se a grande quantidade de biotita com häbito poiquititioo, envolvendo os minerais de granulagão fina. Se-53 pode sex denominada biotita microm -melteigito.

Como jä foi mencionado, a amostra se-ioz se caracte riza pelo piroxênio augitico; ela possui, ainda, pouca nefe lina, alëm de biotita muito freallente, ocupando os espasos entre os outros minerais. Os acessörios mais importantes são opacos, bastante frequentes, e perovskita. os piroxê nios são prismäticos e alongados e, juntamente com a bioti ta, apresentam-se suborientados. Esta variedade de meltei gito pode representar um diaue cortardo as rochas uttrabasi cas. Pelo tipo de piroxento presente, ela se assemetha ao piroxenito se-95 da rabelaz.

A sequência de cmiscirisacäo dos minerais nos ijoli tos é duvidoso, pois os três principais minerais, piroxênio, biotita e feidspatöide, são em parte contemporâneos. Exis tem aristais maioxes de piroxentio e biotita, envolvendo grâa nutos de nefelina.

As rabelas 4 e $4 a$ contêm os resultados da analizse quimica de três amostras de Juquir, bem como suas respecti vas normas, ao lado de uma anälise parcial citada por Knecht e Felicissimo Jx. (1939). Para comparacão, são apresenta das as anatises quimicas de algumas rochas similares encon tradas na literatura.

A amostra $D$, pelo que se depreende da citagão de Knecht e Eelieissimo dx. (1939), deve provis do mesmo afle ramento que Se-50; hä certa discrepâtrcia entre as duas an $\vec{a}$ irses, talves devida a uma variagão na proporgão dos mine rais constituintes: Se-50 possui um teor muito elevado em $\mathrm{K}_{2} \mathrm{O}$, não condizente com a composicão modal, o que pode ser devido a uma maiox quantidade de biotita no material anali sado do que na lâmina estudada. A composicão real dessa amostra deve sex maiss semelhante à anälise modal de se-53, 


\begin{tabular}{|c|c|c|c|c|c|c|c|c|c|}
\hline & $5 e-50$ & $S e-103$ & $s-7$ & $D$ & $E$ & F & $G$ & $B$ & $I$ \\
\hline $\mathrm{SiO}_{2}$ & 43,30 & 38,60 & 41,50 & 41,80 & 40,9 & 43,84 & 42,58 & 41,90 & 40,90 \\
\hline $\mathrm{TiO}_{2}$ & 1,06 & 2,72 & 1,58 & - & 2,75 & 4,12 & 1,41 & 2,21 & 3,99 \\
\hline $\mathrm{A}_{2} \mathrm{O}_{3}$ & 13,43 & 10,37 & 17,02 & 16,44 & 16,1 & 12,03 & 78,46 & 12,20 & 13,65 \\
\hline $\mathrm{Fe}_{2} \mathrm{O}_{3}$ & 3,19 & 5,96 & 5,10 & & 5,06 & 5,33 & 4,01 & 6,41 & 6,67 \\
\hline EeO & 5,57 & 7,90 & 4,01 & & 4,55 & 6,30 & 4,19 & 4,32 & 7,14 \\
\hline uno & 0,09 & 0,09 & 0,03 & - & 0,23 & nd: & 0,20 & 0,22 & - \\
\hline $\mathrm{MgO}$ & 8,69 & 12,93 & 4,72 & 3,91 & 3,82 & 8,59 & 3,22 & 5,45 & 8,35 \\
\hline $\mathrm{CaO}$ & 9,55 & 13,46 & 11,26 & 13,68 & 13,5 & 8,88 & 11,38 & 16,60 & 13,28 \\
\hline $\mathrm{Da} \mathrm{C}_{2} \mathrm{O}$ & 6,59 & 1,94 & 8,13 & 5,49 & 7,13 & 6,37 & 9,55 & 5,10 & 3,06 \\
\hline$x_{2} \mathrm{O}$ & 5,19 & 3,55 & 3.05 & 3,99 & 2,26 & 3,76 & 2,55 & 2,66 & 1,65 \\
\hline${ }_{2} \mathrm{O}^{+}$ & - & - & - & - & - & 0,32 & 0,55 & 0,87 & 0,50 \\
\hline${ }_{2} \mathrm{O}^{-}$ & 0,37 & 0,28 & 0,11 & - & - & 0,29 & - & - & - \\
\hline$P_{2} O_{5}$ & 0,05 & 0,70 & 1,26 & - & 1,61 & 0,38 & 1,52 & 1,24 & 0,81 \\
\hline $\mathrm{CO}_{2}$ & 0,37 & 0,11 & 0,70 & - & - & 0,17 & 0,38 & 0,82 & - \\
\hline Total & 97,45 & 98,61 & 98,47 & 101,41 & 97,91 & 100,38 & 100,00 & 100,00 & 100,00 \\
\hline
\end{tabular}

Se-50 - Ijolito (Biotita ijolito?) - base do Horro do Serrote, lado oeste, Juquizá.

Se-103- Biotita melteigito - pröximo ao brejo do ribeirão Bigua, na base noroeste do Morro do Serrote, Juquiā.

$S-7$ - Tjolito - Guaviruva, Juqui.a.

- "Dicue de ijolito" - base do Morro do serrote, perto do brejo do ribei räo Bigua - Rnecht e Felicissimo Jr. (1939).

- Biotita melteigito - Itapirapuã - Gomes (1967).

- Mica melteigito - Havete, Caldas de Monchique, Algarve, Portugal - Lacroiz (1922), citceão em Johannsen (1938).

- Ijolito - Média de 11 amostras - Dockolds (1954).

- Melteigito - Mëdia de 9 amostras - Hockolds (1954).

- Melieigito com titanoaugita - Mëdia de 3 amostras - Hoekolds (1954).

Tabeta 4: Composigão quimica de rochas ijoititicas. 
$o x$

$A b$

An

Ne

Le

Ac

$D i\left\{\begin{array}{l}W O \\ E n \\ E s\end{array}\right.$

Cs

$01\left\{\begin{array}{l}F O \\ F a\end{array}\right.$

Ce

$A p$

II

$M t$

$$
S e-50
$$

$$
S e-203
$$

$$
9,21
$$

10,59

$16,9 ?$

8,17

3,97

3,05

0,93

10,16

15,35

4,66

0,22

0,10

1.45

$-$
70,03

8,92

1,11

8,38

20,38

2,53

0,28

7,48

3,83

6,20 $s-7$

0,24

0,92

42,70

6,74

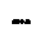

13,19

12,70

0,40

2,47
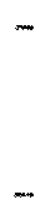

$x, 73$

$2,5 \%$

2,15

5,40

CIPW, modifo Niggli (seg。 Barth, $195 \%$

Tabela 4a: Normas moleculares de rochas ijoliticas de suquiä.

pois sua anälise quimica se aproxima mais dos valores më dios que Nockolds (1954, p. 1028) apresenta para melteigi tos, do que aquêles referentes ass ijotitos. A anălise qui misa de se-50 também ë mais semelhante à composizäo do me teigito citado por Johannsen (1038), proveniente da area de Navete, portugal, wioo em biotita o originalmente denominado ollgarvito por Lacroix. 
A anälise quimioa confirma que se-103 corresponde a um tipo intermediario entre melteigito tipioo e piroxe nito; ela se destaca dos demais rochas do grupo, na região de Juquia, pelos beores elevados de MgO e CaO e pela pobre

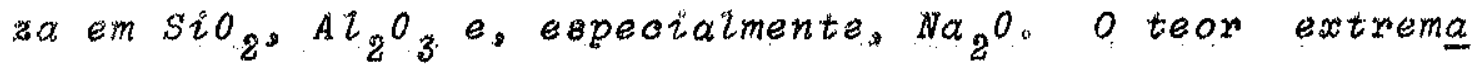
mente baixo dête ültimo öxido ê explicado pela quantidade muito reduaida de nefelina e peio fato do piroxênio sex ri co em $\mathrm{CaO}$ e $\mathrm{MgO}$, mas präticamente desprovido de $\mathrm{Na}_{2} \mathrm{O}_{\text {. Eata }}$ amostra pode ser oomparada aos melteigitos com titanoaugi ta, oitados por Nookolds (1954, p. 1028).

\section{5) - Sienitos}

\section{a) Modo de ocoxxênoia e Distribuigão}

As rochas sieniticas na regiäo de ruquiä, como se vexifica no mapa geológico (Anexo 1). ooupam duas äreas diatintas: 1 - o corpo sienitico isolado do Morro da Casa de Pedra, oiveundado pxinorpalmente pos gnaisses, alêm de quartzitos na parte oul. Caracteriza-se pela ocorrêntia de grande matacõed, em parte identificăvei em fotografia aéxea na parte desmatada do moxro. Sua extensão exata năo Eonheoida, pois, 30 ocorrem blocos, talves deslocados de sua posigão original. A passagem para os gnaisaes enoai xantes inolui uma zona de metassomatismo de oontato: na realidade sua distribuisão pode ser menor do que a årea in dieada no mapa geolögico. 2 - Sienitos oiroundados por ro wha ultrabåsicas. Eles afloxam em um conjunto de moxo te aredondados e circundados pos brejos. Ineluem a ärea denominada Guaviruva, onde ooorre grande numero de blocos * afloxamentos. As variedades são maxosoópicamente dife rentes, mas aua mineralogia ë bastante semelhante.

A sul e oeste desta segunda ocorrïnoia, existem dua axsas sem afloxamentos, também constituidas por morro te arredondados. No mapa geologico foram inoluida na re giäo ocupada por roohas ultrabäsicas, mas a morfologita do 
texpeno sugere a eventual presenga de sientios.

b) - Minexazogia

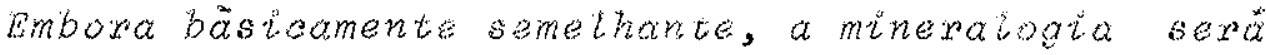
disoutida em separado para cada um dos corpos, pois o habi to e a composigão dos minerats a aferente.

Siention do Moxro da Casa de pedra

Säo constituidos pringipatmente por feldspotos po

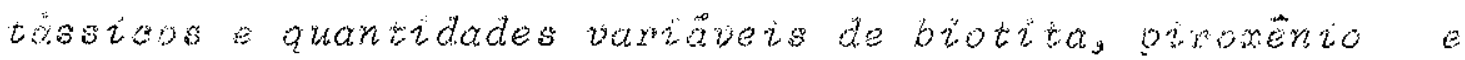
feidspatoides; os acessomitimeorantes sao: titantion apa

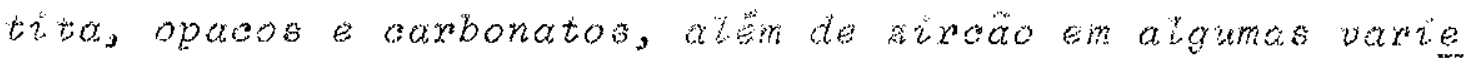

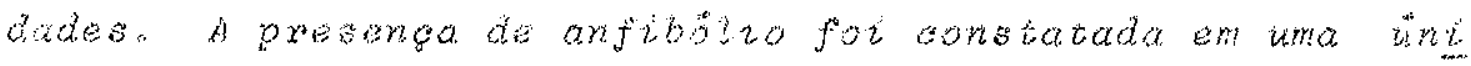
sis lamtina.

Feddapotos

Os feldspatos sab os minexare predominantes, dis gando a perfazer mais de 80\% dos constituintes. Apreson.

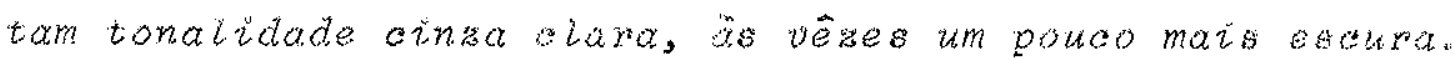
Trata-se de ortualasio pertitico ligeiramente turvo, aom freqliente geminagäo Caxlsbad. Seus grãos apsestram habs to a longado, com 0,3 a $6 \mathrm{~mm}$ de largura, enquanto o compri mento varia entre menos de $i \mathrm{~mm}$ e 1 cm embora alguns iridi viduos possam atingix $\%$ cm.

\section{Blotita}

A biotita ocoxye em tôdas as amostras, sendo às về aes pratroamente o ürioo minerai mafico presente; sua pro

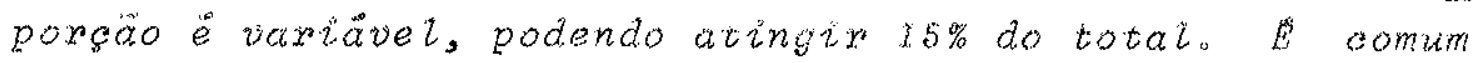
estar associada a piroxento opacos e titanita, em espe cial a pximeiro; em outros casos estä isolado no mero dos feldspatos.

A biotita exibe pleorroismo forte e sua côs, em $x$, varia entre marrom averme thado e amarelo marrom. 


\section{Pน̆xoxền}

os piroxênios são de duas gexaeões, mostrando häbi tos distintos. A maior parte ocorre em grânulos, muito fre qllentemente associados a biotita; em algumas lâminas, no en tanto, forma agulhas prismäticas alongadas, isoladas ou em pequenas concentragões.

O primeiro tipo, mais comum, apresenta granulagäo finc a mêdia, sendo raras vêzes maior que $2 \mathrm{~mm}$. Embora pre dominem gräos alotriomörficos, alauns têm caräcter prismäti co, tendendo ao idiomoxirimo. sua coloragão é variável, em geral esverdada. Cristais muito claros, levemente casta nhos, são somuns em algumas variedades, possuindo então bor da de cor verde maís intensa. o pirroxênio castanho, segun do o angulo de extinsão, é augitico; suas bordas, bem como o piroxenio verde, correspondem a egirina-augita, com pleo croilsmo moderado.

o piroxientio que forma agulhas pertence a uma fase posterior e estä associado a outros minexais, tambem de gra nutagão fina, que substituem os componentes originais da po cho isse piroxentio apresenta cor verde, interso pleo croismo e ângulo de extincáo por volta de 100 , em relagão X. Trata-se de uma variedade muito rica na molécula ggixi na, sendo talvez egirina pura os cristats a ângulo de extingão menor do que 100. As agulhas podem ter. comprimento superior a $1 \mathrm{~mm}$, mas sua largura ë muito peque na.

\section{Feldspatoides}

Os feldspatöides ocorrem entre feldspatos ou assom ciados a piroxênio, biotita e titanita, sendo representados pox nefeirina, cancrinita sodalita.

A nefeliria se apresenta em grãos de atë $3-a m m$, qua se sempre intexsticiais; cristats idiomórjicos sâo raros. Nas amostras possui côx rosada a branca, enquanto em lamina ë incolor e iimpida, contendo pequenas inclusōes e impure. 
zas. A nefelina pode englobar poiquiliticamente os outros minerais, exceto feldspato; por exemplo, na amostra se-6o engloba piroxento, anfibölio, opacos, titanita e biotita.

Nas boxdas, a nefelina muitas vêzes estä alterada para canarinita; essa transformagão tambêm existe, em menor escala, ao longo de fraturas do mineral. Em raras läminas, a cancrinita $\ddot{e}$ o feldspatioide dominante, no entanto, está restrita a aiguns veios que cortam a rocha primitiva. os gräos de cancrinita são finos, em gexal menores do que $1 \mathrm{~mm}$, limpidos e se distinguem da nefelina pela birrefringencia um pouco maior.

A gumas amostras apresentam, em pequenos veios, um feldispatôide de granulacão fina a ocasionalmente média, lim pido e de relêvo distinto em relaça à nefelina e cancrinita: é provãvel que se trate de sodalita, pelo caráater isó tropo, com indice de refragão pouco menor do que 1, 49. Im uma ünia amostra êse mineral aparenta ser um constituinte primorio.

\section{Anfibo 2 ios}

Na iamina se-60 ocorrem frequentes axistais de anfi bolio, de cor marrom a esverdeada, pleocröico 1 X-marrom a vexmelhado a marrom claro; y-maxrom escuro; z-esverdeado a maxrom escuroj. Biotita e piroxênio verde substituem êsse mineral nas bordas ou quase totalmente, consexvando, porëm, sua antiga forma. o ângulo de estingão $2:$ e è de 120, tra tanoo-se, provàvelmente, de uma hornblenda comum. A substi tuigão parcial e sua distribuigão restrita sugerem que èsse anfibolio seja remanescente de um gnaisse muito fenitizado, transformado em rocha de composicão sienitica.

\section{Titanita}

E mais importante dos minerais acessörios, desta cando-se, macroscópicamente, por sua côr amarezada. A tita nita ocorre em tôdas as amostras estudadas, quase sempre. 
com forma navicular e dimensões atë um milimetro ou pouno mais, tendo sido um dos primeiros minerais a se formax. Al gumas vêzes exibe geminagào simples.

Em värias lâminas, quando em contato com aarisirit ta, a titanita apresenta nas bordas um mineral opaco, pro duto de sua transformogão. Sob forte oumento verifiad-se que êsue nineral opaco ê formado por numerosos gxartulos fi nos, por vëses alongados, provävel rutilo ou ilmenita. pos sivelmertie, a alteragão da titanita liberou silica e cail cio, que contribuiram para a formagão da cancrinita.

\section{Carbonatos}

Alguns sienitos sontem pequena proporsão de carbo natos, que, em gexal, se concentram em delgados veios. Ex oppionalmente, ocorrem tambëm carbonatos em gräos intexs tiatais, Na amostra sems, os carbonatos intersiteiais se taro assodiados a cristais limpidos de albita, que se for mam nas boxdas dos feldspatos pertiticos.

opacos

Os minerais oparos ocoxrem em pequenas quantidades, näo ultrapassando 2 a $3 \%$, mas estäo sempre presentes, de preferencicia associados aos minerais mäficos. São consti iuidos por magnetita e vaive izmenita, em gränulos finos a médios. Pirrotita, identifieavel por sua corr amarela e propriedades magnëticas, é comum; em geral è granular, em boxa lis vëzes aparega associada a feldspatöides e piroxe nito fino, formando fillêtes.

Apatita

A apatita estä presente em pequena quantidade;cons titui cristais idiomörficos e de granulasão fina, dispersos na rooka. 


\section{Zireão}

Ä̈gumas lâminas, especialmente se-84, apresentam grãos de ziroão, tendendo ao idiomorfirsmo.

Sienitos Ciroundados pox Rochas vitrabäsicas

Os sienitos encontrados no interior do somplexo alcalino, são constituidos por feldspato, feldspatoidese piroxênio, alëm de biotita. Entre os acessơniog, destacan-se titanita, opacos e apatita.

\section{Feldspatos}

Masroscopicamentie, os feldspatos possuem oolsa

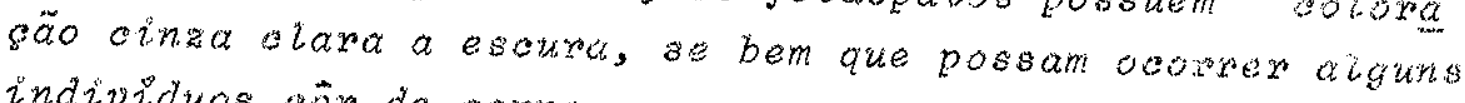
individuos obx de axne, que pareoem ser mais frequentes nas rochas de granulacão mais grosia: individuos esverdea dos aparesem em uma ou outra amostina.

Na mazoma das variedades predominam feldspawos alongados, muitias vêses esm geminagäo simples; os aris tais são timpidus a granulacão varia de fina a grossa. Emboxa, em gexal, apxesentem granulagäo igua à dos ouths consituintes, hâ algumds rochas am que osorrem fenooxis tain mais desenvolvidos, atë $1 \mathrm{~cm}$, porém sem orientagá,

o prinaipal constituinte é feldapato potasiboo pax titico, de habito alotriomorfico ou ripiforme. Nos ixaivi duos ripiformes ë muito oomum a geminagáo segundo carlsbad; - caräater pertitido evidente em varrias amosiras, näo sendo reconheoivel em outras. Geminagão segundo Baveno pode ocoxrer em coxtes de contornos retangulares. Gratos ou manchas de albira-oingoolasio, exibindo geminagäo poirs sintëtica segundo a ter da stbita, sấ raros e quase sem pre restritios as bordas de aristais pertitioos maisres.

Em rasas amostras, predominam feldspatos alotrio mórficos, turvos sem geminagaxo, que podem envolver poi quiliticamente todos os outros constituintes, em especia?. 
os mais finos. Hiles apresentam lamelas de exsoluswo perti ticas, em grande nümero, e sua granulacão è muito variavel, desde 0,5 até $\% \mathrm{~mm}$.

\section{Feidspatơ 2 des}

Säo wepresentados pox nefelina e cancrintio suber dinada. Nas rochas oom feldspato ripiferme, a nefeltra o corre entre grãos de feldspato, notando-se certa tanderida do idiomorfino, que se caracterial pela presenga de con tomos retangulares. Guando a nefelina esta inclutia nos feldspatcs, é azotriomörfica tim lamina é incolor e limb da, on atgo turva devido a alteragão incipiente. Owario en globada por outros minerais, pox sua ves, pode contex gra nuios e prismas muito finos de pixoxênio verde, alem de outras inclusoes, finissimas, näo identificadas. sind gra nulagão gexalmente vaxia entre o, 1 a $2 \mathrm{~mm}$, emboxa possi a tingiz $2-3 \mathrm{~mm}$ em amostxas oom feldspatos mats desenwolitidos e sem forma proppia.

Nas rochas om feldspatos turvos e poiquilitiose. a nefelina estä associada ao piroxentio ou constitui artsme ragoes de varrios individuos. ouando ocorre em gräox tsola dos incluidos no feldspato ê freallentemente i. "iomónfica, embora seus cantos possom estar arredondados, indreando op rosäo parcial. Tambëm neste caso são freqllentes firks in clusoes de piroxênio na nefelina.

Cancriniva ë bastante comum, formando-se a paritix. de nefelina. Cristais maioxes de cancrinita podem orower no contato de nefeitina com carbonatos tardios.

Em algumas lâminas, a nefelina se altera em lim agre? gado fino, contendo carbonatos e outros minerais näo iden itificaveis, de côr marrom muito clara e turvos.

\section{Pirroxénios}

A quantidade de piroxênios ë variävel, podendo atin gïr $20 \%$, mas em alguns sienitos êles se tornam batitantes ra 
ros, sendo entäo a biotita o minexal máfico mais frequlerte.

Os piroxênios mais comuns são constituidos por eq rina-augita, bastante rica na molécula egirina, como indi cam a ör verde carregada e ôngulo de extincão. Fm a gumas amostras, os piroxênios apresentam nucleo quase inos Lor, mais augitico, enquanto as boxdas são verdes. os uns tais em gexal säo alotriomorficos. embora não sejam rayos individuos alongados com tendências prismäticas. Na mais: ria das vêses, sua granulagao é menor do que $1 \mathrm{~mm}$ e apenas em uma rocha, de granulagão mais grossa, ocorrem frequen

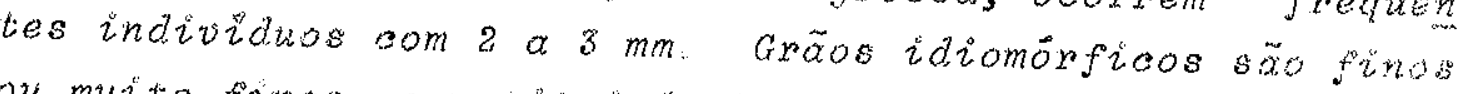
ou muito finos, constituindo inclusöes em feldspato e nefe lina os piroxênios podem contex inelusốs de biotitia, mas tambëm podem estax ciroundados por êsse minerat.

o pleocroismo è semelhante äquête dos piroxênis constituintes dos ijolitos, ou seja, verde escuro em $x$; yer de em $y$ e verde amaxelado em $z$.

Algumas rochas, que devem provir de wonas de conts to com pixoxenito, contêm piroxênio quase incolor, astodix do a plagiocläsio. Tanto o piroxénio, como tambe̊m a biotz. ta o os minexais opacos existentes, neste caso, possuem bow das quelifitioas de piroxentio verde, de granulagäo mulb fina.

\section{Bïotita}

Biotita marrom, sem forma propxia a quase idiomön fica, edom nestes sienitos; ocorre em quantidade variz vet e algumas vêzes $\vec{e}$ o mineral mäfico mais abundante. im bora esteja preferencialmente associada cos piroxentos e pacos, a biotita pode se apresentax dispersa entre a nefe... lina e o feidspato. o pleocxoismo é intenso e, em $x_{3} a$ côr varia entre marrom amarelado e marrom avermethado.

Titanita

E um acessörio comum em tôdas as amostras, sendo tan. 
geral idiomörfica (navicular), com granulacão fina a mëdia, podendo exibix geminacăo. euando em contato com carbonatos, a titanita pode tex suas bordas parcialmente alteradas para um mineral opaco, como jä foi descrito acima.

\section{Apatita}

Prismas alongados ou grãos alotriomörficos de apati ta são comuns como mineral acessorio dêstes sienitos, não utrapassando 3\%. A apatita possui granuląão variável, en tre fina e mëdia, e ocorre dispersa ou agrupada irregutarmen te.

\section{opacos}

Säo acessörios comuns, representados por magnetita e sulfetos amarelos. A magnetita é de granulacão fina a mé dia e apresenta-se dispersa na rocha, muitas vêzes associa da a biotita, que pode formar uma coroa em sua volta. pix. rotita é o sulfêto presente, que ocorre como mineral tardio de pequenos veios que cortam a rocha.

\section{Caxbonatos}

Os carbonatos aparecem como produto de alteracão de nefielina, sendo então muito finos, ou como mineral intersti cial, de granulacão mëdía a grossa. Neste segundo caso, comum a formacão de cancrinita entre os grãos de nefelina e carbonato; êste ültimo, muitas vêzes estä envolvido por can crinita. o carbonato presente provaivelmente $\vec{e}$ calcita.

\section{c) - Petrografia}

Os sienitos do Morro da Casa de pedra são mesocräti cos, sem estruturas caracteristicas, freqllentemente corta dos por diques mais escuros. os feldspatos apresentam dis txibuigão irxegular, côr cinza e granulagão bem maior do que 
os minerais mäficos. As rochas se caractexizam pela granu lasão, que varia entre mëdia e grossa, e pela textura hipi diomörfica granulars o que permite diferenciä-las dos sieni tos do Guaviruva, em gexal mais finos.

Mineralögicamente, nota-se a acentuada predominän cia de feldspatos, ao lado de feldspatöides em quantidade variável; por exemplo, na lämina se-84 êsses ültimos mine rais são raros, enquanto em se-60 se tornam bem mais abun dantes (Tabela 5). Essas duas amostras säo consideradas re presentativas dos sienitos do Morro da Casa de Pedra. Outras variedades, examinadas em lâmina apresentam maior quantida de de feldspatöides do que se-84, o que significa que esta $\ddot{e}$ especialmente pobre em nefelina.

Pela classificagão de Johannsen (1938), as rochas correspondem a nefelina sienito (Se-60) e pulaskito (Se-84). Na realidade, a primeira (Se-60) pode ser uma rocha muito fenitizada, pois ocoxre anfibölio, em parte substituido por piroxênio e biotita, e restos de feldspato com alterasão pa ra epidoto, semelhantes aos minerais dos gnaisses; por outro Zado, a alta proporgäo de feldspatöides näo è normal em fe
nitos.

Os sienitos do Guaviruva e arredores. por sua vez. tambëm săo mesocräticoss mais escuros do que os tipos acima descritos. A granulacäo, à vista desarmada, ébastante ho mogênea, mas em alguns casos existem cristais centimëtxicos de feldspatos de côr cinzas as vêzes avermelhados ou esver deados. Esses minerais podem exibir häbito ripiformes po rẹm näo săo oxientados. As rochas säo cortadas por diques de granulasäo fina e podem apresentar algumas partes peg matiticas, essencialmente constituidas por feldspatos.

Ao microscópio, possuem granulasäo entre fina e më dia e sua textura, em geral, $\vec{e}$ hipidiomörfica granuiar. AI gumas variedades mostram, em meio a uma matriz de granulá gao bastante regular, certa quantidade de grãos maiores, de nefelina, piroxênio e feldspato, muitas vëzes tendendo ao idiomorfismo: sua textura então ë porfiritica ous mais apro 
priadamente, micro-porfiritica.

Nestes sienitos destaca-se o habito ripifoxme dos feldspatos, bem diverso das rochas do Morro da Casa de Pe dra. Pela composigao modat constituem nefelina sienitosita bela 5), mas o habito ripiforme dos seus feldspatos, segundo alguns autores, permite definimlos como possuidores de tex tura traquitoide, com o que passariam a ser derominados foiaitos porfiriticos ou nao. Algumas amostras apresentam granulasäo fina. representando. talves. diques mais ou me nos espessos, porem a falta de orientacaio dos minerais, bem como o modo de ocorrência nas permitem conclusoes seguras.

Ao lado dos sienitos predominantes, duas outras va riedades devem ser citadas; uma delas parece corresponder a ijolitos feldspatizados, nas quais os feldspatoides estao parcialnente substituidos e envolvidos por feldspatos aloa linos alotriomorficos; restam ainda algumas manchas de com posigáo ijolitica ou seja. granutos de piroxenio verde e nefelina, ao lado de alguma biotita e ivitanita.

o segundo tipo, distinto dos sienitos propriamevite ditos estä relacionado do grupo dos pixoxenitos: os piroxe nios castanho claros, alëm da biotita e opasos, possuem uma coroa de finas agulhas de pixoxénio verde egixinico. Alëm disso, os feldspatos originais, representados por plagiocla sios de composicao andesinzea sao substituidos por varieda des mais ricas em potassio. Esta transformacão pode atin gir estådios avangados, nos quais predominam pixoxenios ver. des de composigäo egirinawangitica que ainda podem posisur nücleos claros, ao lado de feldspato pertitico; restos de plagioclasio podem existir. Nefelina tambëm ocoxre, mas em quantidades muito pequenas. A vista de seu häbito granuiar. alta proporcaio de feldspato alcalino e escassez de nefelina. essas rochas podem ser denominadas pulaskito ou umptekito. Provavelmente, correspondem a piroxenitos ou gabros aicaliw. nos. transformados por agäo de contato com ijolitos ou sie nitos posteriores.

A extensão dos fenomenos de sienitizagao de ijoti 
tos e rochas piroxeniticas näo é conhecida, mas pode ter si do de relativa impoxtancias em relasão à ärea total ocupada pelos sienitos.

A Tabela 5 mostra a composigäo modal de diversos sienitos da região. As diferencas mais importantes se refe. rem às quantidades relativas de feldspatos, nefelina e piro $x$ ênio. A proporsão de feldspatos é bastante variärel. des de $30 \%$ ate $85 \%$ dos constituintes. A nefelina tambëm apre senta distribuigão pouco homogênea, mas raramente $\ddot{e}$ infe rior a 10\%; constituem excecao duas amostras onde näo atin ge $3 \%$, tratando-se de variedades muito ricas em feldspatos. o piroxênio pode perfazer quase $25 \%$ dos constituintes, mas normalmente e̊ mais subordinado.

A relacáo entre as quantidades de feldspatos e feldspatöides, nas rochas sieniticas de suquiä, varia entre 98:2 e 44:56: em um unico caso hä mais feldspatioides do que feldspatoss tratandomse de um ijolito feldspatizado. A re lagaio entre fëlsicos e måficos, por sua ves varia entre 90:10 e 62:38, havendo, portanto, acentuada predominancia dos minerais claros. Na região näo existem representantes da classe 3 de Johannsen (1939), ou sejas dos tềrmos equiva lentes mais ricos em minerais mäficos.

A amostra $S-17$ é diferente de tödas as outras,pois seu principal mineral måfico ë a biotita, havendo apenas grä nulos de piroxênio verde, em quantidade muito restritasaliem disso, carbonatos intersticiais perfazem $13 \%$ dos constituin tes.

As variedades $S e-16$ e $S-11$ são ijolitos feldspati zados, enquanto se-99. presumivelmente, originoumse de uma rocha piroxenitica.

Cinco amostras de sienito foram analisadas quimica mente, sendo duas delas provenientes do Morro da Casa de pe dra e as outras da ärea do Guaviruvas apenas em Sw27 näo foi verificada a composicão modal, mas ela corresponde a um ijo lito feldspatizado, semethante à Se-16 e S-11 da Tabela 5. As composigôs quimicas constam da Tabela 6 . 
Casa de Pedra

Guaviruva

\begin{tabular}{|c|c|c|c|c|c|c|c|c|c|}
\hline Feldipato alcalino & 56,5 & 84,5 & 74,5 & 35,5 & $\begin{array}{c}S-14 \\
54,5\end{array}$ & $\begin{array}{l}S-17 \\
52\end{array}$ & $\begin{array}{l}S e-99 \\
73\end{array}$ & $\begin{array}{l}S e-16 \\
33\end{array}$ & $\begin{array}{l}S-11 \\
29\end{array}$ \\
\hline Defelina & & 2,5 & 21 & 32 & 22 & .17 & 1,5 & 28 & 36 \\
\hline Cancrinita e sodalita & 122,0 & 1 & 2 & 7,5 & 2,5 & 6,5 & - & 0,5 & 0,5 \\
\hline Pirozênio & 9,5 & 0,5 & 7,5 & 22 & 10,5 & $t x_{0}$ & 14,5 & 23 & 18,5 \\
\hline Biotita & 4.5 & 8 & 8 & 3 & 2,5 & 7,5 & 5,5 & 6,5 & 5,5 \\
\hline Titanita & 3 & 0,5 & 1 & 3 & 2 & 1,5 & 1,5 & 4 & 3 \\
\hline Opacos & 1,5 & 1 & 1,5 & 1 & 3 & 1 & 2,5 & 4 & 3,5 \\
\hline Apatita & 0,5 & tr. & tr. & 1 & 0,5 & 2,5 & 1 & 0,5 & 3 \\
\hline Carbonatos & \pm 20 & 1,5 & $t r$. & $t x_{0}$ & 1,5 & 13 & 0,5 & 0,5 & 1,5 \\
\hline Anfibölio & 1,5 & - & - & - & - & - & - & - & - \\
\hline Outros & 0,5 & $t r$ & - & 2 & 1 & 0,5 & $t r$. & - & - \\
\hline Feldspatos/Feläspatöides & $82: 18$ & $96: 4$ & $85: 15$ & $51: 49$ & $69: 31$ & $69: 31$ & $98: 2$ & $60: 40$ & $44: 50$ \\
\hline Fërsicos/Mäjicos & $80: 20$ & $20: 10$ & $88: 12$ & $71: 29$ & $82: 18$ & $20: 10$ & $78: 24$ & $62: 38$ & $70: 30$ \\
\hline
\end{tabular}

Tabela 5: Composigão modal de sienitos da intrusão alcalina de juquiă. 


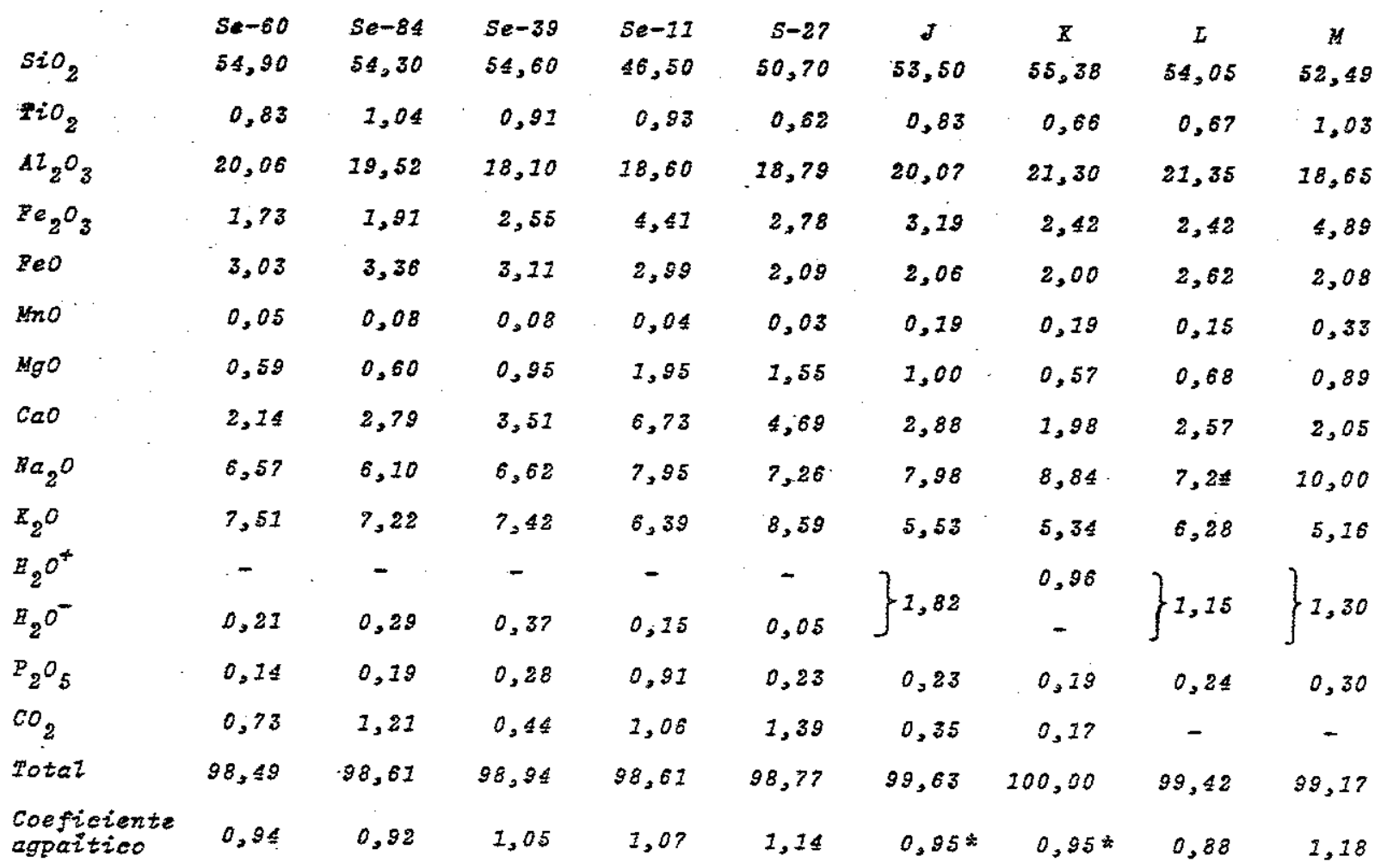

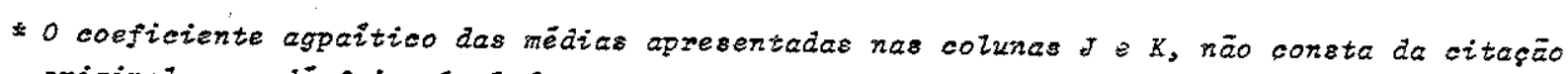
original, mas ja foi calculado por Gerasimodskit.

Se-50 - Iefelina sienito - Morro da Casa de Pedra, Juquia.

Se-34 - Befelina zientto - Morro da Casa de Peära, Juquiá.

Se-3s - Befelina aisnito - Guaviruva, Juquiá.

Se-1I - Hefeina sienito - Guaviruva, Juquiz̈.

S-27 - Uefeline sienito (Ijolito feldspatizado) - Guaviruva, Juquiā.

- Hédia de 34 amostrar de nefelina sienitos - Johangen (1938).

$x$ - Média de 80 anälises de nefeline airnitos - Mockolds (1954).

$L$ - Composigão média de 156 amostras miasquiticas - Gerasimovskit (1966).

$M$ - Composigāo média de 129 amostras agpaiticas - Gerarimovskii (1966).

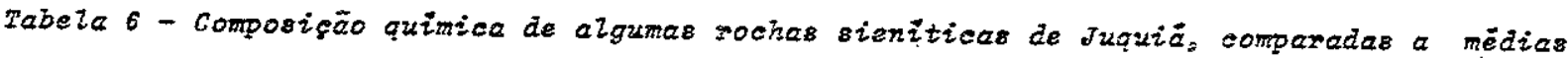
de diverses localizader. 


$$
5 e-60
$$

$$
5 e=84
$$

Se.w 39

Se-17

9w2?

or

43.69

42,20

43,22

28,73

32,34

$A, b$

23.59

26,59

15,49

An

3.02

4.51

Ne

$$
20.70
$$

$$
16,56
$$

23,27

$37 \% 26$

30.06

Le

Ac
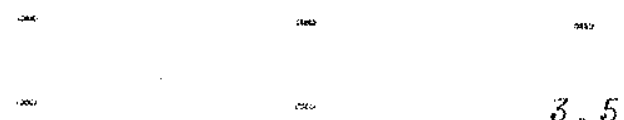

$$
3 x_{0}
$$

30,30

A

$D i \begin{cases}W O & 0,30 \\ E_{n} n & 0,32 \\ E s & 0,47\end{cases}$

0.16

3,54

5,93

$\because 29$

5.05

9.04

$s_{3} 0$

0.06

2,44

5,24

$3: 3$

0,09

2,61

2.30

1.82

$\mathrm{Cs}$

$02 \begin{cases}F_{0} & 0,96 \\ F \alpha & 7,42\end{cases}$

7.88

0,37

0,78

:

.50

7,82

0,72

0.39

$a$

2,89

300

7,30

$=$

30

$A p$

0,29

0,39

0,58

$\because, 61$

0.46

II

7,24

1.43

3,25

7.86

0.34

Mt

7,98

1.97

7,30

7,20

$x_{x y}$

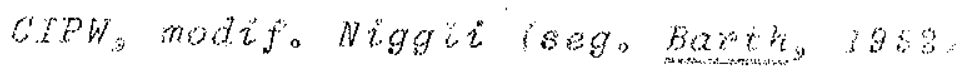

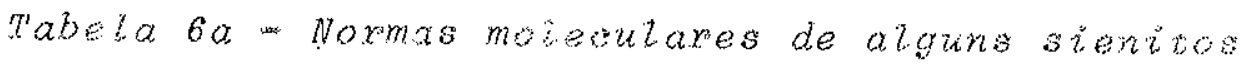
da area de Juquiza

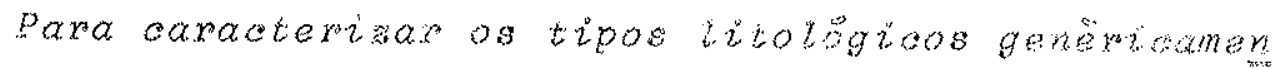
te denominados sienitos fot utilizado su indice ae agpaim cidade Gerasimovskit 7956 e 7966 , Sorensen. 7560 ) que e a relagao entre a soma dos rimeros moleculares de Wag o $\mathrm{K}_{2} \mathrm{O}$ e o nümero molecular de $\mathrm{Al}_{2} \mathrm{O}_{3}$ o valor que so deve ado tax paxa distinguir os grupos dos agpaitos e miasquitos discutido. Alguns autoxes adotam indice de agpaícidade ignal a 1 e outros 1.2; isto porque se verificou que algumas ro chas apesar de possuirem indices superioxes a , apresentam 
värias caracteristicas que as tomam mais semethantes a mias quitos, por exemplo, a composigáo mineralögica total, os mi nerais de titänio presentes "rezaga entre $\mathrm{Na} \mathrm{O}_{2}$ e $\mathrm{K}_{2} \mathrm{O}$ " Pot essa razäo. no presente trabalho, nao se utiliza exolusivam mente o indice de agpaioiadade para distinguir entre os dots grupos, mas tambèm a composifäo mineralogica as aryatexis ticas dos minerais de titanio presentes, a relagao entre a cxiss e alumina e a natureza do alcali predominante.

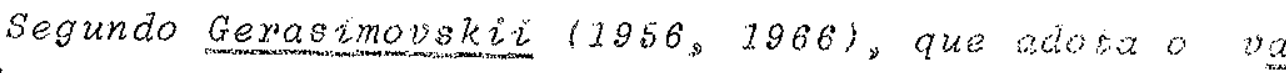
Lox unitårio como limite entre os agpartos e miasquisos nu maiopia das ocorrencias existem apenas rochas aloalinas com saracter agpaitico; o numeso de zocalidades com varitadades tanto agpaiticas como miasquiticas ë relativamente pequevo. sendo mais raras ainda as ocorrências com caxateristisas apenas miasquiticas. Embora na titeratura sejam enoontradas citagoes do indice de agpatotade das mais diversas roshas alcalinas neste trabatho au whor e caloulado apenas paru

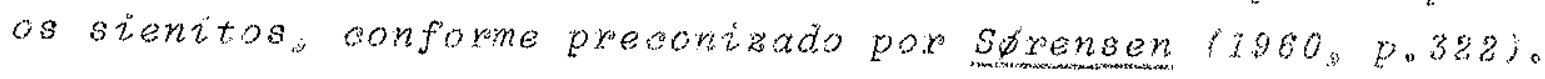

IIm relacaio ao valox unitario os ocefielentes de agpaicidade indieam que os sienitos de Juquis possum ravto caräeter miasquitio (Morro da Casa de pedral como agpaition (Guaviruvas alèm de alguns valopes prörimos ao limite entre os dois grupos.

A trabela 6 apresentas alem das anärses quimuas de rochas de Juquia. a composigäo mëdia determinada por varios autores de numerosos nefezina sienitos de outras toralidades. As medias das collinas o $J$ se referem a sienitos em geral. serdo mais conveniente, porem, a comparagao oom os valises mëdios citados por Gerasimovskt (1966) por haver uma subdz visäo baseada no indice de agpaicidade.

De um modo geral. os sienitos do Moxro da casa de Pedra distinguemse da mëdia dos miasquitos, principalmertis peto alto teor em $\mathrm{K}_{2} \mathrm{O}$ e pelos valores baixos de $\mathrm{Na}_{2} \mathrm{O}_{3} \mathrm{AL}_{2} \mathrm{O}_{3}$ e Ee, ${ }_{3}{ }_{3}$ O teor de Feo ë Ligeiramente superior As rochas provenientes do Guavixuva e arredores, pox sua vers apesar de possuirem indices de agpaicidade superiores a unidade, a 
presentam algumas caracteristicas que as assemenam aos mias quitos. Ressabta. em primeiro iugar, a granäe quartidade de $\mathrm{K}_{2}$ O presentes maior cu proxima do tecr de $\mathrm{Na}_{2} \mathrm{O}_{\mathrm{i}}$ o que gexal

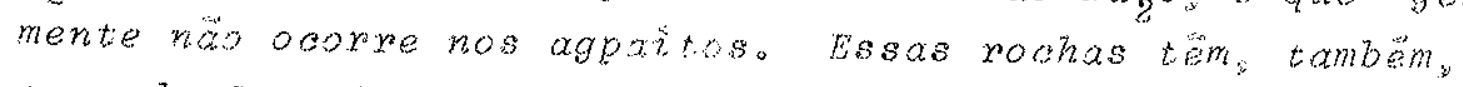

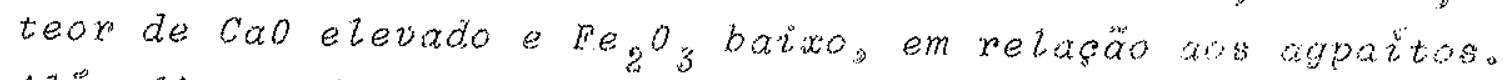
Alëm disso, do ponto de wista mineralógico foide labela 5 is a presenca de titanita, unioo mineral de tivanio encontrado. além de biotitas, ë tipiod.

\section{6) Roohas de Diques}

\section{a) Modo de ocorrendia e Detsibuicao}

Em diversos locats da intrusäo alcalina form $\mathrm{kag}$ lizadas rowhas hipoabissais algumas vezes com oxientaga pro nunciada dos constituintes mineragogicoso os diques nax orop rem na sua posigao originat, mas apenas somo biosos de drmen

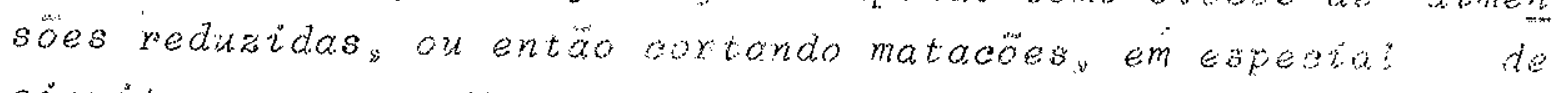
sientess como no Moro da casa de pedra Eles tambim form

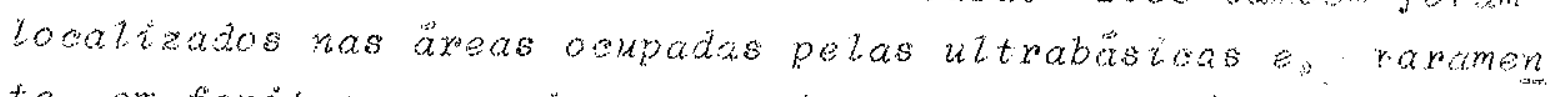

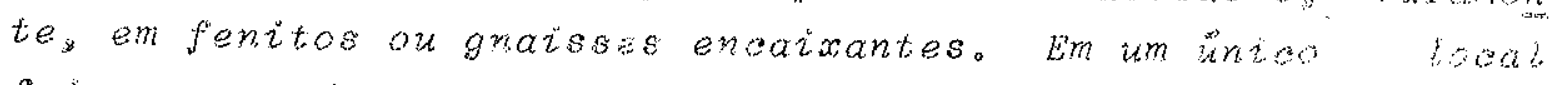
foi encontrado um dique roptando piroxento "in situ" mas ambos estao totalmente alterados. havendo apenas pequena difes

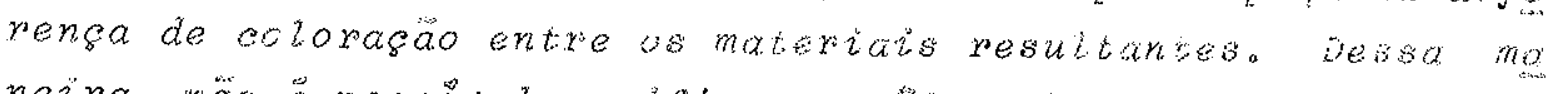
neiras năo é possivel vexificar se elles obedeosm a arguma s. pientagao preferencia ou se sua disposigáo è iregular.

Diques feldspätibos mesocrăticos säo somuns oortando os sientios da area do Guaviruva e do Morro da Casa de pedra. Alguns blooos foxam tambem ensontrados ras areas poliparas por rochas ultrabastous. sem qualquer indixaga sonsistente ve bre o modo de ocorrencia originat. A espessura dos diques va ria de arguns centimetros a deoimetros, mas algumas veses c correm blocos com mais de meio metro de diametro, sem atingir o contatio com a encaixante.

As rochas ultrabisitas, por sua ves, säo dontadas pot diques gexalmente escuros e muito ricos em piroxenios grada se pode prearsar sobre sua ospessura maximas pois ocorrem apenas 
em fragmentos de dimensoses entre 20 e 30 centimetrowo como ja foi mencionado alguns diauss claros tambë foram eneon trados nessas areas.

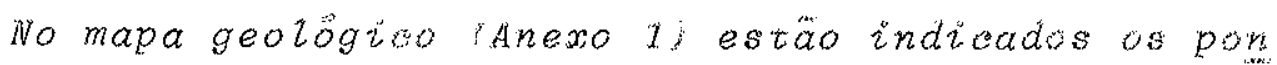
tos nos quais as rochas de diques foram encontradas.

A distributgà dos diques nas rochas fenitisadas a encaixanies, em tôno de complexos alcolinos, tem sido esu dada em numerosas ocorrencuas; geralmente, elles constituem sistemas definidos radiats ou concêntricos em rolasă a th trusao. Algumas cocalidades apxesentam grande numeco de ai ques. prestandowse a estudos detalhados como é o caso de Alns (vo Eekermann, 1928, 1948, 1961, 1966) e Tundulu i Gaxw son. 7959 e $1966 \%$ Sua freqlencia parece estar tolacionada ao nivel de exposigao da estrutuxa alcaina diminuindo en profundiadade.

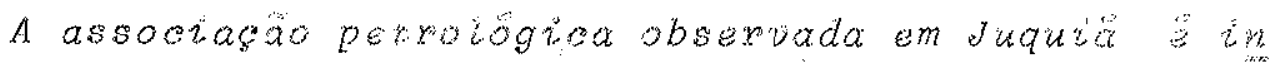
dioation de um niver profundo da estrutura magmationo ho campo, apenas dois pequenos diques foxam loadizados nas ep caixantes, embora provaveimente outros existam, na podendo sex mapeados devido ao interso intemperismo.

\section{b) Mingralogia}

Em fungao da oomposigao mineralogica. as robhas po dem ser divididas em trés grapos principais. $t$ de onposin sao sieniticas 2) rochs me anocuaticas de sompositga seme

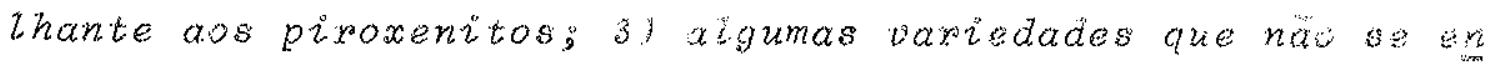
caixam nos tipos anterioxes.

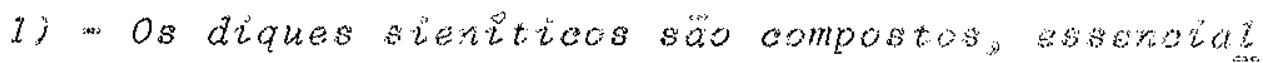
mente, por feldspato aloalino, piroxenio verde, faldspatiz des e biotita.

Os feldspatos didiznos, possuem habivo ripufowe e geminagao segundo Carisbad na maioria dos individyos. Em numerosas amostras os feldspatos ripiformes sab orientados. Algumas variedades apresentam freqllentes ferocrisias de feldspato; tambem geminados segundo Carlsoad es por veres. 
segundo Baveno. Esses fenoeristais podem ser periticos e. mais raxamente, zonados; de maneira geral, estas oarateris ticas se restringen as bordas dos cristais.

os pixoxerios sao de os verde bastante intena em bora possam possuir nüoleo quase incolor. o häbito prisma tico alongado ë comm, especialmente quando hä orientagäo dos minerais; os prismas podem obedecer a essa oriertagäo. mas en alguns sasos sua disposigäo é irregular. A granuza fao, em geral, acompanha a dos feldspatos, variando de mitio fina a fina. Em algumas anostras ocorrem fenooristais om relativa abundanoia. atingirdo ate dois milimetros de compri mento. Em casos rayos. Esses minerais mostram lobito asiou Zar muito fino, estand catioamente dispostos. Nos piroxe nios verdes o pleosmono e mutio intenso; verde esure cu garyafa em $X_{*}$ amareto estrevdexdo em 2 e verde em $y_{\text {. }}$ Pelos ângubos de extirgao apresentam composigão de egirina augim ta mas os minerais actoulares de algumas pochas wio de om posigar egixinica os nübos incolores de alguis oxis tais. sab angituoos. Whas os diques estudados apenas um no possui piroxento sn sut omposisao. A quantidade desse minerat, no extanto, e muito nariavez, conforme se berifira na Tabeza?.

Os fezdspatides sxo representados por nefleina izm

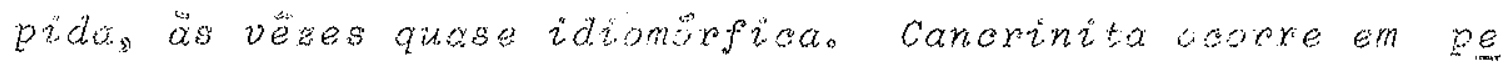
quena quantidade na matinia das amostras, owiginando=se pela alteragao de nefelina. Em alguns diquess exingem finos veisi posteriores. mitto rioos em cancrinitio e pobres em carbonatos. Certas rochas porizriticas contem fenoaristais de nefeirna, que terdem ao iajomorismo, pudendo inculu grande numero de aguithas firws de piroxinio concentradas de prefereneia nas boräas dos gracs.

8) Os aiqus piroxenticos ra matoria dos dasos. sao porfiriticos. A masea fundamentals de gravulagar fina a muito fina. eoristitida essencialmente poy piroxenio e feldspato, com quantidades variaveis de biotita el minersis opacos. os fenooristain por sua vess säo constituldos por piroxento e olivira maís raramente pox piroxento e felds 
pato. Em geral êstes fenocristais são idiomörficos poden do exibix zonamento pronuneiado.

A olivina ocorre apenas como fenoaristais, ä̈guns dos quais sâ zonados na periferia. Este mineral pode mos. tray forte arorosäo vas boxdas, o que dä origem a consen tragoes de opacos; em outros casos, a olivina estä tota merite alterada em opreos e oxtopiroxênio. Nas proximida des dos cristais de olivina ha maior concentrasão de bioti ta, que se desenvolve, de preferência, em tôrno de mine rais opacos. As vezes, ooorem aristais de biotita bastar te desenvolvidos。

os fenocristais de piroxénio mostram vitido zong mento, caracterisado por variagóes de composigăo ou peia presenga de faixas conceytricas, muito ricas em inclusöes aciouzares orientadas. As bordas dêsses fenocristaìs sem pre apxesentain a mesma composigäo de piroxënio da massa fundamental, onde inclusoes aciculares tambëm säo frogllen tes. No interiox dos ferrowistais podem existir pequenas placas de biotita e grass de minerais opacos ou feldspato. em torno dos quais. as inclusöes aciculares estäo ausentes. - piroxenrio fino da massa fundamental muitas vëzes tambèm mostra caräcter prismaitoo pronunciado. Na maioria das amostras. o mineral \& aglitro, levemente acastanhado; $\mathrm{Em}$ alguns casos exibe pleocroismo muito fraco, amarelado ou arroxeado.

- feldspato, representado por plagiocläsio, oovrise na massa fundamentai, cono principal constituinte ao lado de piroxênio, ou na forma de fenocristais, faltando entio a olivina. os fenocristais säo idiomörficos e zonados;mos tram geminagäo Camlsbad e polissintëtica, segundo lei da albita. mas tambem do periclinio. A composicäo è variävel devido ao zonamento, mas gexalmente corresponde a andesina. os feldspatos da massa fundamental, na maioria das laminas, opresentam habito ripiforme.

A massa fundamentat das rochas melanoaräticas pos sui grande quantidade de opasos e proporgäo variävel de biotita. Im algumas läminas notamse a concentragäo de opa 
cos ao zongo das bordas de fenocristais de piroxënio.

3) - o teroeiro grupo de diques, inelui duas amos tras. A primeira (Sew74, e composta de piroxênio augiti co esverdeado claro e zonado, nefelina, biotita e opacos. A outra é composta por plagioolasio biotita, piroxênio as tanho, frequentes gräos de sulfetos e quartzo, näo apresen tando. portanto, associagäo mineralögica alcalina tipica.

\section{c) Petrografia}

Os diques na rarea do complexo alcalino säo prinei palmente tinguaibos. em sua maior parte intrusivos nos ne felina sienitos do Morro da Casa de Pedra e Guaviruva, alèm de rowhas lamprofiricas contando as ultrabäsicas. Alèm disso. hä duas amostras que näo se enquadram nesses dois grupos principais. um mispomelteigito e uma rocha de compo

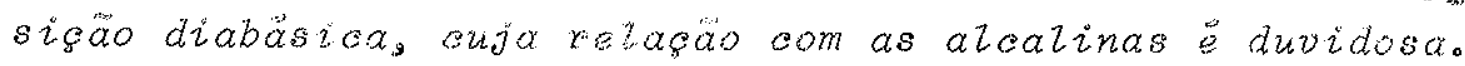

Macrosobpoamense os diques sieniticos săo mesow praticos e de granubasao fina a muito fina. Algumas varie. dades do Morro da Casa de pedra mostram manchas escuras bem definidas. mas restritas sompostas de biotita. podendo a presentar nucleo de pirocênio. A vista desamada, apenas algumas amostras possuem nitida orientasão dos mineraisyem lamina, no entanto. os fieldspatos ripiformes muitas vezss sao orientados. carasterizando uma textura traquitöide. Ra ras variedades exibem textura tinguaitica, devida a presen sa de piroxenios ariulares com orientacão caötica. Crande parte das rochas sienitiaas do Morro da Casa de Pedra possui textura porfixitiod; jä na area do Guaviruva säo ge ralmente hipidionoricas granulares.

Os diques melanosiaticos säo caracterizados pela textura porfiritica quase sempre presente; ela pode ser ve xificada inclusive em amostras de mão, em especial nas su perficies semi=azteradas.

A Tabela 7 mostra a composição modal de tress tin guaitos. um micromeltergito e duas rochas escuras inclui 
das no grupo dos lamprö́firos. A amostra se-26 pode ser denominada camptonito, pox sua filiasäo alcalina, enquantio Se-35 é considerada um espessartito, apesar do plagioalasio estar no limite andesinawabradorita e de sua provavel filia sâo alcalina.

os unicos diques alcalinos encontrados no em basamento apresentam composisöes diferentes: um ë sieniti cos portador de nefelina. localizado cêrca de $1 \mathrm{~km}$ a noroes te da intrusao. o outros proveniente de um bloco encontra do proximo ao contato entre sienitos e gnaisses, no Morro da Casa de pedra, possivelmente cortando êstes, corresponde a um tinguaito. Caractexizase pela presenca de cristais mi limêtricos de cancrinita posterior, envolvendo e substituin do feldspatos.

$$
S e-45 \quad S e-47 \quad S e-61 \quad S e-74 \quad S e-26 \quad S e-35
$$

\begin{tabular}{|c|c|c|c|c|c|c|}
\hline Feldspato & 75 & 6.5 & 50 & - & 18,5 & 54,5 \\
\hline Nefelina & & & 20 & 21 & - &. \\
\hline Cancrinita & $t r_{0}$ & 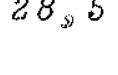 & 3 & - & $\approx$ & - \\
\hline Pixoxênio & 23,5 & 1 & 4 & 58,5 & 42 & 28 \\
\hline opacos & $t r_{0}$ & 3,5 & 3 & 9 & 14,5 & 4 \\
\hline Biotita & 1 & & 10 & 11 & 8,5 & $1: 5$ \\
\hline ritanita & $t x_{0}$ & & 8 & $=$ & - & - \\
\hline Carbonatos & - & 2 & 7,5 & - & - & - \\
\hline Apatita & 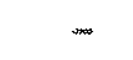 & & 0,5 & - & - & - \\
\hline orivina & - & - & - & - & 16,5 & 1 \\
\hline outros & - & - & 0,5 & - & $\ldots$ & - \\
\hline
\end{tabular}

Tabela 7: Comprigá modal de alguns diques de duquia.

Um terceiro dique, de espessura decimétrica, coxta o gnaisse nas proximidades da intrusão, mas năo apre senta nentium mineral que confirme sua filiagăo alcalina, pois contem inclusive certa quantidade de quartzo. E posm sivel que esta rocha tenha caräcter diabâsico. 
Os Zampröfixos e tinguaitos säo considerados correspondentes às ultimas manifestagöes da intrusäo das ro chas ultrabäsicas e sieniticas, respectivamente.

\section{7) Carbonatitos \\ a) Modo de ocorrência e Distribuicäo}

Os carbonatitos ocupam considerävel ärea do Morro do Serrote. Esta elevacäo possui $211 \mathrm{~m}$ de altura $e$ uma ärea aproximada de $2 \mathrm{~km}^{2}$. situando-se proxximo ao limite oeste da intrusäo alcalina. A moxfologia do Morro do serro te ë caracteristica; em planta seu contônno é quase circu Zax, com pequena proeminencia na parte sudeste, encontrandom -se cercado por brejos. Rossui forma aproximadamente coni ca, em que ressalta uma estrutura circular a meía altura. muito nitida na parte norte (Foto 1), que separa a parte cen tral de outra mais externa. Na porsäo mais elevada o morro $\ddot{e}$ constituido apenas por carbonatitos, näo sendo possivel de limitar os contatos com exatidão. Entre as rochas limitro fes, parecem predominar os pixoxenitos, ocorrendo tambëm variedades ijoliticas. i possivel, mesmo, que estas tenham distribuigäo muito mais ampla do que se poderia infexix pelo limitado numero de exposiçoes.

o estudo dos minerais resistentes dos solos do Morro do serrote mostrou que na parte central ha predominan cia de magnetita, oxidos secundarios de ferro e baritas alèm de o̊xidos de manganês. Na parte extexna, por sua vez, a ba rita e̊ muito menos frequente e praticamente desaparece. com excesäo da poxcáo proxima a jazida de fosfatos; na parte ex terna, os minerais mais importantes são: quartzo, quase ine xistente na parte interior, magnetita e ôxidos de ferro, atëm 
Foto I: O Norro do Serrote visto peio filanco peste, notando-se à esqueraia, a meia aitira, parte de uma feigão aneiars provävel contato do carbonatito interro e externo. Em primeiro pianos bařxada aiuvial poseiveimente com rochas piroxeniticas subjacentes. 
de mica alterada, comum em alguns locais, es às vêzes apati ta. Os teores em $P_{2} O_{5}$ desses solos näo säo correlacionàveis a feicáo morfolögica ciroular acima referida. Situamse en tre 1 e $5 \%$ de $\mathrm{P}_{2} \mathrm{O}_{5}$ ate 10 metros de profundidade, exceto $r_{\text {a }}$ parte sul onde esta localizada a jazida de fosfatos; mesta area os teores sao mais elevados especialmente em profundi dades superiores a 12 metros. Este comportamento sexa anali sado em detalhe no capitulo referente as possibilidades eco nomicas da ärea. A dosagem geoquimica parcial do fösforo con tiáo em solos foi efetuada em uma sërie de amostras, em per fis radiais ao cume do mowo mas apenas a parte superiox do moxro apxesentou valoxes abtos, näo coincidindo evtretantos com a axea interna a feicäo sircular (vide cap. V).

Um perfil cuntilométrico, efetuado atrates de soda a estrutura (Figura 2, $p .12$ ) cortou o Moxro do sexw

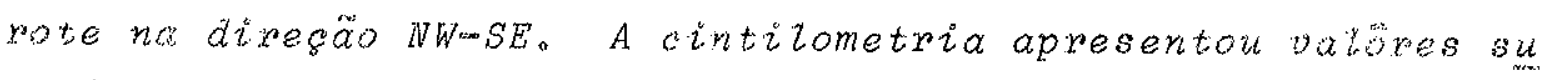
periores ao "back-ground" de 1,5 a 2 vëzes, na parte exterra a estrutura anelax, em especial no flanco sudeste inquans do tado noroeste os valomes sao mais baixos. Na parto th terna a estrutura, o contraste é acentuado, entre 5 a 10 ve wes provavelmente wefletindo diferensas litologibas tritwe as duas partes do morro.

Nas exposigós, a superficie do carboratito em geral evidencia os efeitos da dissolucaio, formandowse peque nas caneluras. os minerais mais resistentes, principalmente magnetita, destacam se nessas superficies. Em aiguns aflora mentos observarse uma estriture bandada, devida a presenca de pequenas camadas escuras na rocha clara. Veios de barita de pequena espessura tambèm podem ser encontrados.

Na frente de trabalho, onde estäo sendo extrai dos fosfatos, näo oovry arronatito frescos embora nesse is aat tenha sido aberta uma galeria de pesquisa com 30 metros de comprimento, dirigida para o centro do morro.

Duas sondagens efetuadas na parte interna $\vec{a} f e i$. sao anelar atingiram o oxbonatito. A primeira. dirigida pa ra o centro do morro e inotinada de 60\%, aposs atravessar 27 
metros de solo. A segunda sondagem, vertical, aleangou dar bonatito apös perfurar 43 metros de solo. os testemunhos obtidos apxesentam algumas partes bastante intempexisudis. alternadas com outras frescass esse fato pode ser devido a fraturas ou diäclases no carbonatito, ao longo das quais o intemperismo foi mais intenso. A rocha mais fresca asseme tha se as amostras da superfieie quanto a cor e granulacar. mas apresenta manchas milimetricas de sulfetos näo oxidados. Nas amostras de superficie estes minerais normalmenivesta envolvidos por uma omada oxtada e, alëm disso, parte dos carbonatos mais rioos em ferro se apresenta alterada. dando origem a gxidos seoundarios.

Fetiozezmo Jr. (1968) aita tres sondagend efe tuadas, pelo Instituto Googräfico e Geologico de säo pauto. na ärea de ocorencia de fosfatos. Uma dessas sondagens.tr otinada de $45^{\circ}$ em direga ab centro do Morro do Serroter exe outada em 19:3 atingtu axbonatito a cerea de so metros de profundidade. os minarate acessorios presentes. bem romo o granulaga da rocha conforme fot vexifuado em samiras

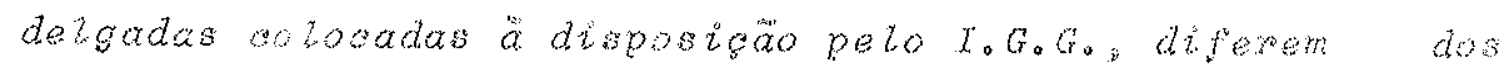
encontrados nas amostras de superficie e nas sordagent da parte interna do morye.

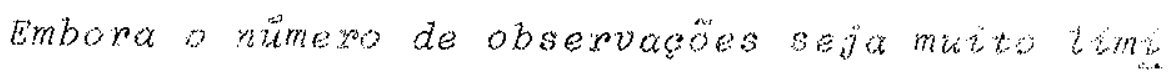

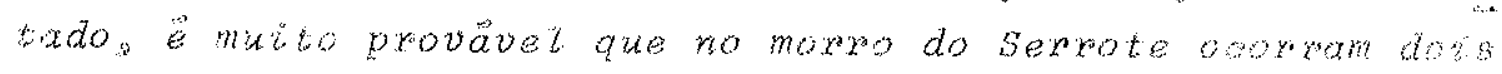

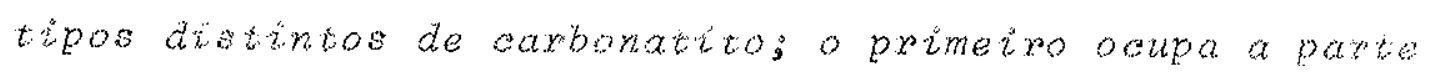
centrat mats elevada enquxnto o outro se situa na parte p?

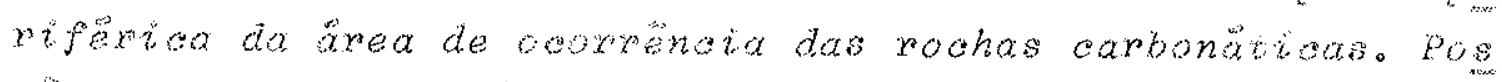

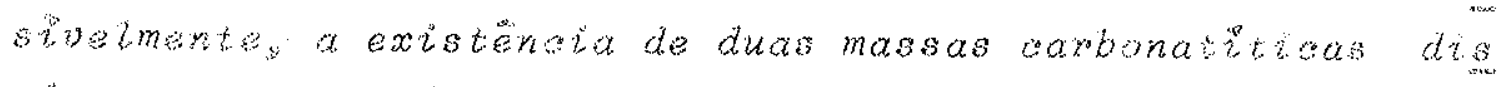

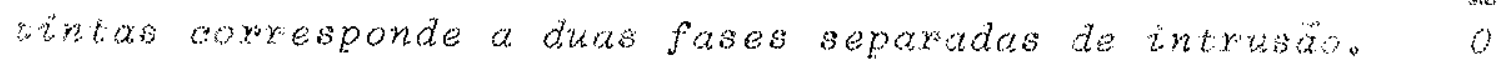

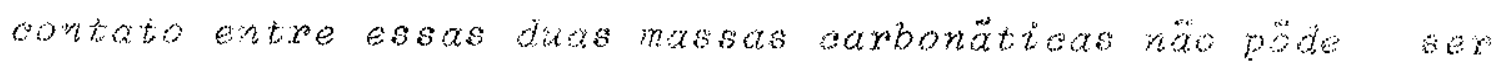
deternirado no campo. Entretanto a descontinuldate morfo

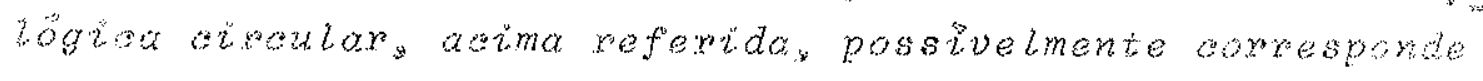
wo thite entre vaxiedades de arbonatito de difererte re sustencta ao intempexismo. outro fato, no entanto potte sex contiderado indieativo da existencia de uma rocha nao mabo matitioa no flanoo norte do morros pois um poso de pasution apresenta uma argiza multo fina diferente da entisterte mo. 
solo que capeia o carbonatito. Em varios locais principa mente no fianco norte, ocoxrem ainda solos ricos em mica a teradx. A existência de corpos e diques carbonatiticos tro regulares associados com outras rochas alcalinas è onnect du em diversas ocorrenctas similareso tista possibilidade tamberm deve ser tevada em considerasăo no caso do Morro do Serrotes em espectal na sua parte norte.

Devido a exigtidade de afioramentos e praveno wumexo de sondagens powoo se poae dizer ssbre a estrutura dos carbonatios e as rezages entre os dois tipos towaling dos. A existentia de drques carbonatiticos dispostos segin do aistenas definidos, cortando os proprios carbonatyousem como as atras rochas alealinas, somente pode ser sugerida om fooe a sua oporenera comum tomalidades congeneres. duquita uma indicaga resse sentido é dada pela exisienoin de de

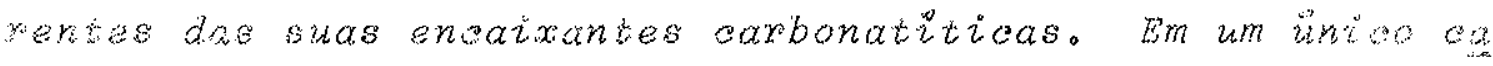
so encontrourse um pequeno dique de carbonatito brawes som

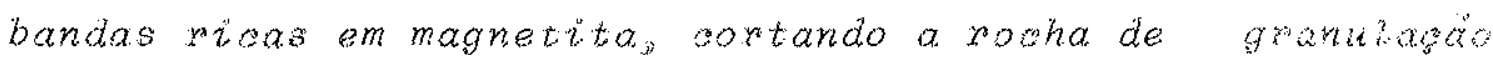
fina (itosit).

Tambem nao a co onhecidas evidencias conoretas sobre a presenga de xenotitos nos carbonatitos oomins em quase todas as roohas desse tipo. A Hnica indicagas. sobre

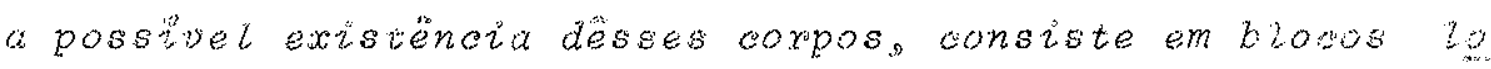
calizads nos fosjatos da jasida na base do Morro do seryro te. Esses blooos totalmente alterados de dimensoes centu metriors quase meto metro de diametro e os averme shada. encontrom se na massa de fosfatos que apresenta coloraga e textura mitio diferentes. Se os fosfatos se oxiginatam partiz de roohxs arbonatitioxs. esses blocos podem xepre sertar cenotitos decompossos conservados na massa de fosfa tos lFoto 31.

Na irea ocupada por carbonatitos (Figura sty tams algumas fraturas ou lineamentos, reconherido pou exame de folografias aéyeas que se lowalizam no ane? exter no. sugerindo a existenoia de un sistema radial de fraturas. devido a intwaco do soppo exponatitico centrat. o anta 
Hoto 2 "Dique de carbonatito coxtando a rocha tambem carbonatitica (x 1,2).

Eoto 3: Bloco de composisäo argitosa e cor avermelhada englobado nos fos fatos, tratandowse de um possivel xe notito alterado. 


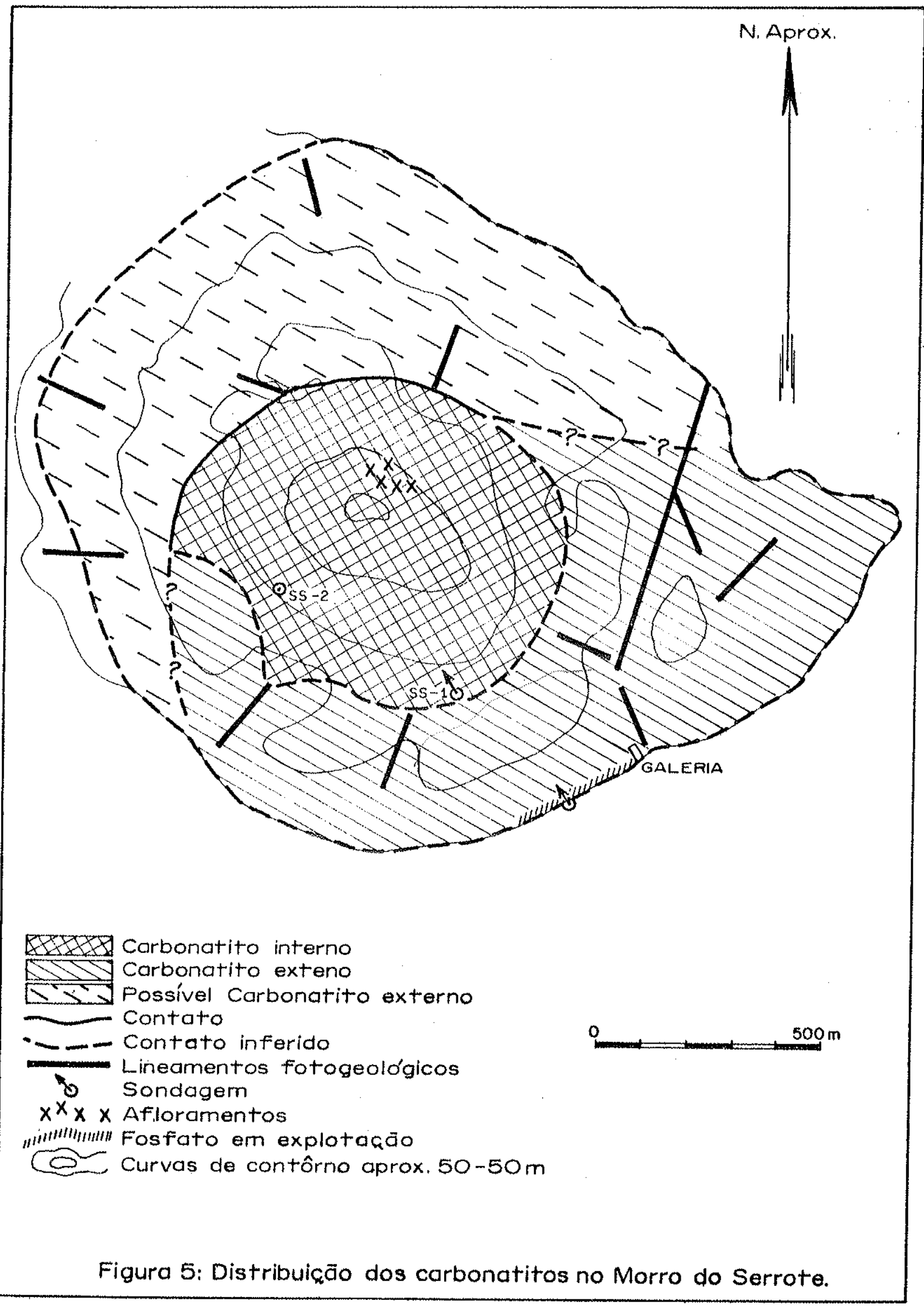


to exteryo do coxpo centrat aparentemente possui foxma do niax, oom seus flanoos merguzhando para fora, de manerra que. em profurdidade, seu diametro pode ser bem maior do que aque so observado em superficie coerca de $0,5 \mathrm{~km}^{2} \%$

A forga linear que separa o Morro do Serrote da pequera salienoia em sua parte sudeste, pode estax peto cionady a um dique ou fatha, pois uma galeria de pesquisaspro xima $a$ frente de mineraga (tigura 5), localizou uma zona de 1 a 2 metros de espessura, constituida de material talooso com granition aboutioss.

Pelos dados apresentados, verificamse que

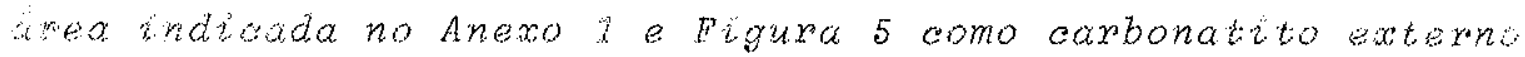
eapenas infexida a partix da rocha carbonatitica locotiaa da em ama hrita sondagem e com auxilio dos mineraiz residuate dos solos.

Admitindo que todo o Morro do Serrote seja dons tituido pow carbonatito, esta rocha ocupa eerea de $15 \%$ do area wtal da intrusas. possuindo forma bastante reguzax. bu ponto de wata moxfologico, ele seria semelhante aos carbora tritos de Jacupixanga. Palabora. Sukulu e Spitskop. entris u tros mas diferente das massas constituidas por numerosos roxpos ixregulares, semi circulares, diques ou "conemeneets" osmo en Bukusu. Tweerivier, Glenover e outros. Em rolagao a areo total da intrusao a percentagem ocupada pelos wribona titos en equili pareae ser maior do que em Jacupiranga on boxa o coppo ombonatitico em si seja bastante modesso. com parado à matores oooxrencias oonhecidas isukulu Bukusu. capuia.

b) Mrnepalogia

Os carbonatitos encontrados na intrusao alsalz na de Juquir apresentam uma composicáo mineralogica relativa mente simples, havendo entretanto diferengas caraotexisitas entre as rochas da parto externa e interna. 
Capbonatito externo

Os dados sobxe esse carbonatito, atravessado por uma hritsa sondagem. foram obtidos a partix de $14 \mathrm{sec}$ soes delgadas, cedidas para estudo pelo I.G.G. de Săo Pau Ho. lissas laminas ja haviam sido descritas em 1948, por plinio de Lima; correspondem ao intervalo entre 36 e 82 metros de profundidade, abaixo do capeamento de minërio josfiatioo.

o estudo das lâminas delgadas indica uma oom posisao bastante unifoxme. nesta perfurasăo. os carbona tos perfaxem de $50 \%$ em volume, nas rochas excepoionalmen te xicas em apatita. ntè quase 100\%. A descrisäo das a mostras. efetuada por Plinio de Lima, contëm uma uniad re fexência a testes de coloragá por meio de nitratio de prata e oxumato de potassio indicando baixa proporeás de salopta As analises quimicas frezicissimo tr. 1968), confirmam a predominanoia de carbonatos dolomitioos. com possibitiade de ocoxier caloita em pequena quantidade.

A granulasäo da rocha varia entre 0,5 e $2 \mathrm{~mm}$. embora tambëm haja algumas manchas de granulaga exelust vamente fina.

Os grâos de carbonato säo eqllidimensionais. podendo sor denteados ou indicar cexta tendencia a idio monfismo. Mostram elivagem nitida e geminagäo ocasional. os carbonatos saso limpidos, mas em algumas laminas exis tem grasos maiores turvos, principalmente nas bordas suge mindo ronamento.

os minerais acessórios mais comuns säo mica. magnetisas apatita. pixooloro e barita. Minerais amarela dos e csverdeados de alterasao (oloxita?) ocoxrem de ma neixa esparsa. Misa alaranjada e magnetita säo os acesse xios de distribuigáo mais regular. 
Lagao muito fina a média. Ela ê comum em algumas taminas rara em outras, mas perfas, apenas, alguns percento em volu. me. Quando mais abundante, ocoxye isolada ou em pequenas manohas associadas a carbonatos. apatita e opacos. A foxma dos graos tende ao idiomorfismo, principatmente nos indrvi duos isolados.

A mica exibe pleoroismo alaranjado a vermelho, mais foxte na diregäo pexpendioulax a clivagem, e extingäo inclinada de 2 a 40 em relagäo aos tracos de ctivagem. As seçoes transversais apresentam olivagem pexpendiatar ao maior alongamento. Im uma unica lamina alguns gräos pos suem nücleo oujo pleocroismo è mais intenso na dixegäo para lela aos tragos de clivagem. enquanto nas bordas ête é seme thante ao primeixo caso.

Os cristais de mica podem mostrar zonamento sa racterizado pela presenea de um materiat eseuro, näo identi fiada, nas partes centrais ou pox wariagöes na intensidade do pleocousmo.

\section{opacos}

Minerais opacos em pequenas quantidades exis tem em quase todas as laminas, entre os carbonotos au engle bados por eles. Sua granulagao varia de muto fina a finas pousas veass atingindo $0,3 \mathrm{~mm}$. Em algumas amostras r roxs em veios carbonäticos posterioress os opacos ocorrem em manehas milimetricas e com maior frequencias associados a mica earbonatos, apatita e oxidos de fexro.

os minerais opacos sao magnetita e bxidos de ferro seeundärios; em grande parte parecem estar assocrados a veios constituidos por carbonatos turvos e de granulara fina semelhantes ao carbonatito interno.

Em gexal, a granulagão da magnetita é fina, aom frequenties graos idiomorficos. Muztos oxistais apresentam

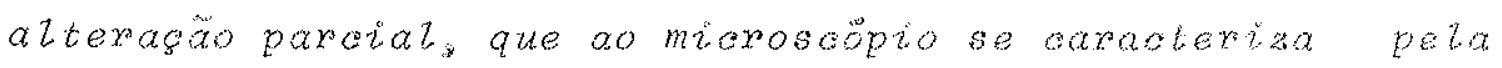
existencla de bordas com cor avermethada. 
Em algumas amostras s cortadas por veios de cax bonatis finos e turvos, hä minerais opacos näo identificados. em manchas milimëtricas e de contornos regulares, sugerindo substitulgo de um mineral preexistente.

\section{Apatita}

A apatita ocorre com habito prismätico, em cris tate alongados de ate $4 \mathrm{~mm}$ de comprimento e $0,4 \mathrm{~mm}$ de largu

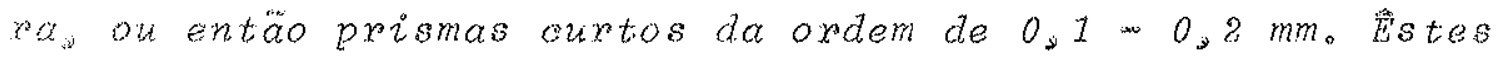
3it timos formam aglomeragoes de 2 a $3 \mathrm{~mm}_{\mathrm{s}}$ notandowe tenden bia ac idiomorismo nos diversos graos.

Muitas veses a apatita apresenta bordas com cors de interferencia mais atta devido a formagão de carbo natowapata (dahtita), conforme jă havia sido deserito por pirinio de lima.

A apatita náo esta disseminada, mas sempre em glomerasies ou fizetes. serdo posterior aos carbonatos da rowh inolusive aqueles de veios posteriores.

os prismas alongados normalmente estäo associa dos a gräos finos, foxmando manchas orientadas, continuas ou interrompidas, as veres com aspecto de veio. Nestas man ahas: a upatita quase não contem incusubes os prismas a longados podem possuir partigao paraleta ao plano basal. Quando a apatita esta chsooiada a magnetitas seus gras en volvem es por vezes, mostram inelusöes dêste minerat.

A apatita tambëm ocorre em manchas näo orienta das. em graos mais ou menos equidimensionais, transformados em dahtita nas bordas ou inteiramente substituidos por esse minaral; os grãos säo rioos em inclusôes finas näo identi fiadas. e minuscutos espacos vazios de forma arredondada. Entre os graos de apatita e dahtitas sao encontrados fre quentes cristais idiomorficos de mica avermethada.

Barita

A barita nao é propriamente un acessorio do 
carbonatito. mas aparece, em uma ünica lâmina, associada a veio carbonatitico posterior, de granulacão fina. Forma cristais largos e alongados, que estão envolvidos por mate rial carbonatico de veio ou se localizam nas bordas dêste.

\section{Piroctoro}

Pequenos cristaís idiomorricos de pirocloro fo ram localizados nas laminas do carbonatito externo, sendo semelhantes ao mineral encontrado no carbonatito interno on de $\stackrel{\infty}{e}$ ais frequente.

\section{Zircâo}

os residuos insoluveis de algumas amostras de solo do carbonatito externo apresentam raros cristais finos a mëdios de zircäo, com dois habitos distintos. Constitui prismas alongados e com cantos arredondados, côr rosa claro a escuro e granuląäo fina: no outro caso, forma bipirami des tetragonais perfeitas, com zona prismätica curta. sendo incolor e de granulasăo atë $2 \mathrm{~mm}$. Ëste mineral parece ser dexivado do carbonatito mais antigo, devido ao local onde foi encontrado.

Carbonatito interno

Dispöe-se de uma boa variedade de amostras des te tipo de carbonatito, o que permitiu a separacão e estudo dos minerais constituintes.

Tambëm neste caso, os carbonatos perfazem a maior parte da rocha, embora os minerais acessorrios sejam mais frequentes do que no tipo de rocha anteriormente des crito. Os minerais acessorios apresentam distribuicão bas tante homogênea em tôdas as amostras, se bem que a barita ienda a ocorrer em manchas, por ser um mineral tardio. en quanto a magnetita pode se concentrar em faixas orientadas lembrando um tipo de textura fluidal. os principais mine rais acessörios säo. pela oxdem de freqliencia aproximada: 
magnetita, barita, ilmenita, pirita, monazita, ancylita, pi roctoro, quartzo, goethita, galena.

Monazita e goethita formam pequenos agregados que preenchem cavidades da rosha, tanto em amostras da super

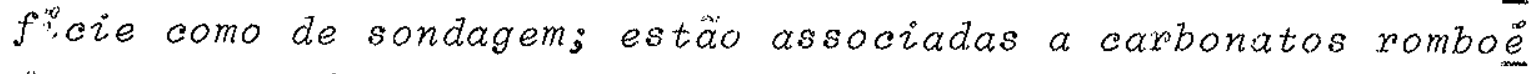
duicos.idiomorficos, de uma fase tardia. Barita, estroncia nita (?) norsethita, ancylita e quartzo tambêm se associam a êsses carbonatos tardios.

\section{Carbonatos}

Como jä foi citado säo os constituintes mais importantes da rocha; em gexal apresentam-se em gräos alo triomorficos e denteados. unja granulacio varia de fina a muito fina. Poucas amostras possuem gräos ocasionais de di mensões maiores do que $0,5 \mathrm{~mm}$.

De um modo geral, hä dois tipos predominantes de carbonatos quanto à granulacäo: um muito fino; com gräos atê $0.1 \mathrm{~mm}$ de diametro. e aspecto turvo; o outro constitui do por gräos de 0,1 a $0,3 \mathrm{~mm}$ de diâmetro, cör branca e as pecto limpido. Esses dois tipos de carbonatos ocorrem em agregados de muitos grãos. que em conjunto podem ou não fors max bandas orientadas; em outros casos, o material mais fi no envolve ou penetra entre os gräos mais grossos. bonatos constituem, portanto duas geragoes distintas. Ra ras vêzes foi notada uma terceira geragão, de carbonato fino $e$ turvo. substituindo as duas anteriores. Algumas amostras apresentam, ainda, um outro tipo de material carbonätico,que, mesmo em lâmina possui coloraçäo marrom intensa. Éle ê constituido por grãos finos, quase limpidos e impregnacöes finissimas de oxidos de ferro: tratamse de provärel mate rial ankeritico alterado. A alteracaio de ankerita e sideri ta, relativamente instaveis. ê descrita em värias ocorrên cias carbonatiticas. Apesar dos termos ankeriticos e side riticos serem considerados, em geral, os ütimos a se for mar nas rochas carbonatiticas, em Juquiä esta relasăo näo pöde sex estabelecida nas poucas amostras em que ocorrem. 
os carbonatos maiores do que $0.3 \mathrm{~mm}$ säo poste yiores aos acima citados es em geral, estão associados a minerais tardios, como por exemplo, barita. seus gräos possuem contornos regulares, podendo ser idiomörficos.

Macroscopicamente, os tipos de carbonatos des critos se diferenciam pox sua coloracão, pois os de granum lagäo maior säo quase brancos, enquanto os mais finos e turvos mostram diversas tonalidades de marrom; o material. ankeritico apresenta côr marrom muito carregada, as vêzes avermethada.

Com a finalidade de determinar a composigäo dos carbonatos, bem como a seqllencia de formacaro das diver sas geragoes, foram feitos värios tipos de ensaios, como medidas do indice de refracăo, analises termo-diferenaiais, difracão de raios $x$ e têcnicas de coloracäo ("staining".. Medidas de indices de refracáo e anälises termo-diferenciais foram efetuadas em diversas fracöes carbonäticas,prinoipat mente na granulaçäo 60-100 mesh $(0,250-0,149 \mathrm{~mm})$ s obtidas por separasaio magnëtica ("Frantw Isodynamic Separator").Ve rificouse que os carbonatos marrons possuem susceptibili dade magnëtica maior do que os quase brancos.

IT 29 fragöes provenientes de 15 amostras de rocha, os carbonatos mais comuns foram concentrados manual mente, efetuando-se a seguix medidas do indice de refracăo w. Essa têcnica foi aplicada por Verwoexd 1966 ) $\mathrm{em}$ va rios carbonatitos sul-africanos, deduzindo-se sua composi säo aproximada do grâfico citado por Winchell (1951, p.115i. A precisäo das medidas no material de Juquiä $\vec{e}$ de \pm 0.003 para os valores abaixo de 1,70 e de $\pm 0,005$ para os indi ces mais altos. Em um total de 41 medidas (Tabela 8 ) verificounse que os carbonatos de corr marrom, em sua maioria. apresentam indices mais altos e säo mais ricos em ferro (parankerita e ankerita) do que aquêtes de côr branca es sencialmente constituidos por magnesiomdolomita. Indices $\underline{w}$ abaixo de 1,679 säo raros, näo tendo sido determinados va lores mais baixos do que 1,675 ; isto confixma que a catoi ta. se existir. ê muito rara nas amostras estudadas. As 
frąöes magnëticas quase sempre contêm mais de um tipo de carbonato, pois, na granulacáo utilizada, säo comuns os in tercrescimentos entre diversos minerais. Alem disso, as fra söes correspondem a um certo intervalo de susceptibilidade magnëtica, não se obtendo a separasão de minerais puros, mas apenas dos termos carbonaticos predominantes. As fracoes se paradas a amperagens maiores do que 1,0, präticamente si con têm magnësio dolomita. enquanto as outras sao constituilas por ankerita ou parankerita, alëm de magnësiowdolomita em quantidades menores.

os carbonatos com ferro podem conter werta quar tidade de manganês substituindo o ferro em suas posigoes. Bs te fato se reflete na presenga de $1 \%$ a $2 \%$ Mno em duas amos tras do carbonatito, mas ësse elemento deve estar presente tambëm em outros minerais, alëm da ankerita.

Comparando os indices de refracäo medidos nas diversas fragöes verificamse ques de um modo geral, hiz grande predominanaia de magnesiowdolomita, seguindo a arkerita s. por fim, a parankerita. Estes dois illtimos minerais säo mais comuns em amostras cuja anälise quimica revela cievado teor de ferro (Tabela 9); em apenas dois casos o teor atto desse elemento ê devido a presenca de magnetita em quantida des acima da mëdia $(C-15$ e $S S-1-9)$.

Com a finatidade de auxiliar na deterninacăo dos varios tipos de carbonatos do carbonatito intexno de Juquias. foram executadas diversas anäises termo-diferenciais em fracoes de diferentes susceptibilidades magnëticas, prove nientes de varias amostras. Tambëm neste caso se uitilizou. em geral, a frasaio 60-100 mesh, separando-se manualmente os sulfetos existentes e triturando o material em almofaris de $\stackrel{\mathscr{a}}{g a t a .}$

o equipamento de anälise termo-diferevoíal uti lizado foi construido no Departamento de Minexalogia, basea do em diversas descrigöes da literatura, especialmente Kerr. e Kulp (1948). Devido a uma sërie de caracteristicas prö prias do aparelho, como taxa de aquecimento de $100 \mathrm{C} / \mathrm{min}$. 


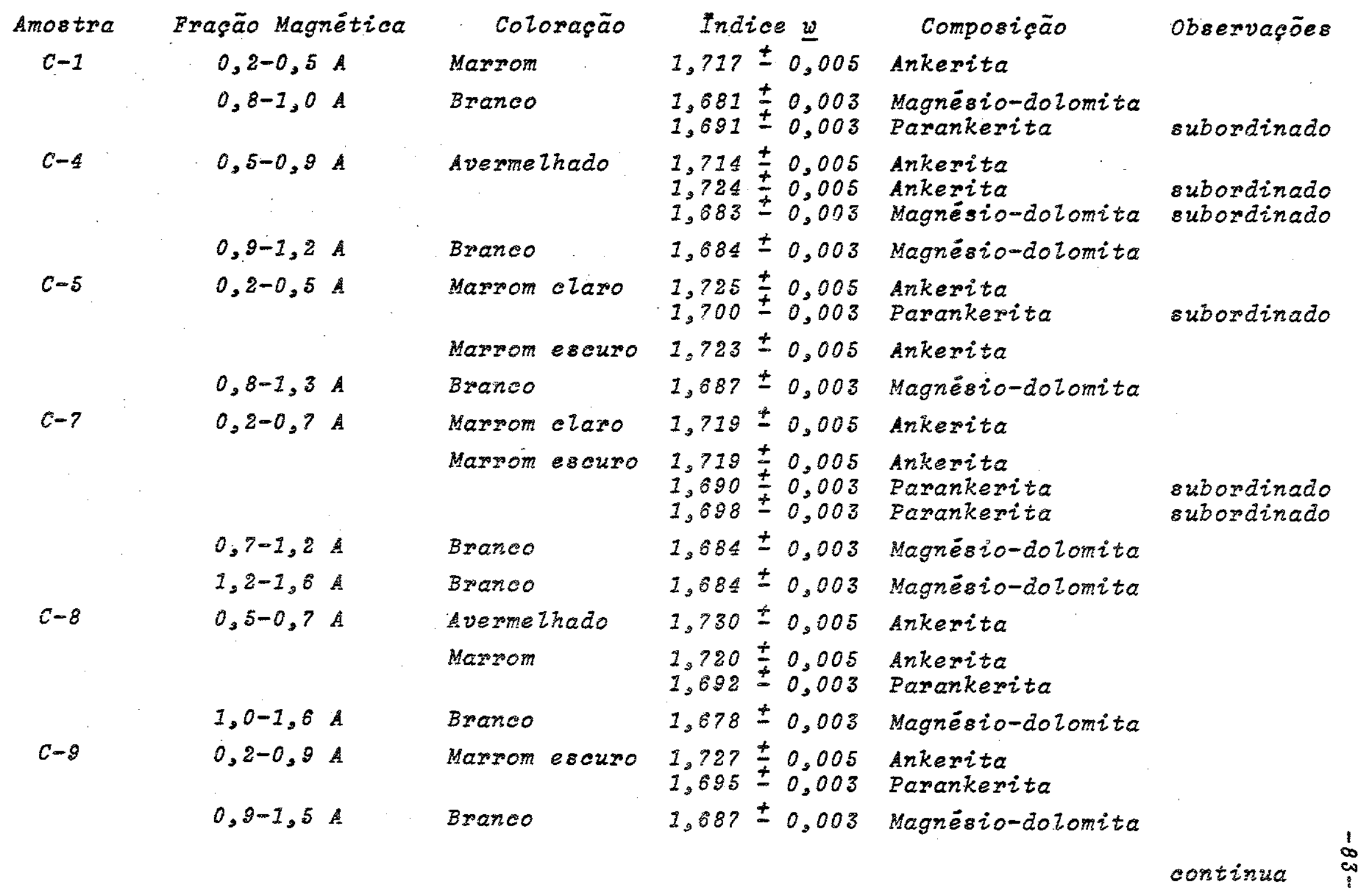




\begin{tabular}{|c|c|c|c|c|c|}
\hline Amostra & Fração Magnëtica & Coloragão & Indice w & Composigão & observações \\
\hline \multirow[t]{2}{*}{$c-11$} & $0,2-1,0 \mathrm{~A}$ & Marmom & $2.725 \pm 0,005$ & Ankerita & \\
\hline & & Branco & $1,681 \pm 0,003$ & Magnésio-dolomita & \\
\hline \multirow[t]{2}{*}{$c-12$} & $0,3-0,5 A$ & Marrom & $\begin{array}{l}1,622 \div 0,003 \\
1,723 \pm 0,005\end{array}$ & $\begin{array}{l}\text { Papankerita } \\
\text { Ankerita }\end{array}$ & \\
\hline & $0,5=0,8 \mathrm{~A}$ & Brasico & $\begin{array}{l}1,687 \pm 0,003 \\
1,711 \pm 0,005\end{array}$ & $\begin{array}{l}\text { Magnesio-dolomita } \\
\text { Ankerita }\end{array}$ & subordinado \\
\hline$c-14$ & $0,6-1,65 \mathrm{~A}$ & Braneo & $1,680 \pm 0,003$ & Magnésio-dolomita & \\
\hline$c-15$ & $0,7-0,9 . A$ & Branco & $1,686 \pm 0,003$ & Magnésio-dolomita & \\
\hline \multirow[t]{2}{*}{$S S-1-3$} & $0,3-0,7 A$ & Branco & $\begin{array}{l}1,684 \pm 0,003 \\
1,720 \pm 0,005\end{array}$ & $\begin{array}{l}\text { Iagnesio-dolomita } \\
\text { Ankerita }\end{array}$ & \\
\hline & $0,7-1,4$ & Broneo & $\begin{array}{l}2,680 \div 0,003 \\
1,705 \pm 0,005\end{array}$ & $\begin{array}{l}\text { Magnésio-dolomita } \\
\text { Parankerita }\end{array}$ & \\
\hline \multirow[t]{2}{*}{$S S-1-6$} & $0,3-1,0 \mathrm{~A}$ & Natrom escuro & $1.686 \pm 0,003$ & Magnesio-2o Zomita & con oxido de $F e$ \\
\hline & $1,0-1,24$ & Marrom elaro & $1,584 \pm 0,003$ & Magnésio-dolomita & \\
\hline$s s-1-\theta$ & $0,6-1 ; 2 \mathrm{~A}$ & $B \geq a n=0$ & $1,681 \pm 0,003$ & Hagresio-âlomita & \\
\hline$S S-1-22$ & $0,8-i=\frac{1}{2} A$ & Eranco & $1,680 \div 0,003$ & Hagnesio-dolomita & \\
\hline $5 S-2-2$ & $0,3-i, 4 A$ & Eroneo & $1,880 \pm 0,003$ & Hagnesio-doZomiza & \\
\hline
\end{tabular}

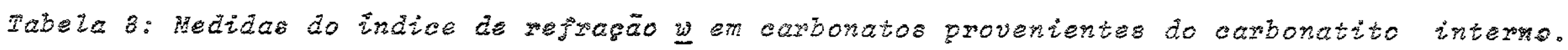


com contrồle manual, o desanvotvimento dos picos endo ou exotërmicos se prowess a temperaturas diferentes das cita das por êsses autores. Alem disso "x faltid de um registro automätico e de temograms de carbonatos puros impede qual. quer tentativa de interpretag quantitativa com esse apare Thamento. Algumas anilises forxm feitas oom recepiralo do material aberto e outras oom reseptaculo fechados a tempera tura de formagao dos pioss e aeu desenvotvimento e mais ou menos constante para cada serio de analises. quando se tra balha com receptaculo fechado obtemmse pions menores e a temperatura mais baixa potas de ceto modo, isto equiwate a operar em atmosfera de co proventente da decomposiga dos carbonatos.

Bastoamerbes foran obtidos dois tipos de cur

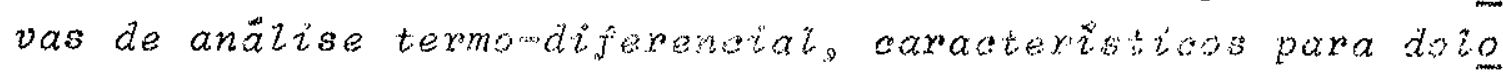
mita e ankerite (Eriguras o 7 ; a iritenstade do primeiro pico da ankerita debe ser consequencia da quantidade varia vet deste mineral. um mitstura oom docomita. Como as leitu ras da diferenga de poteno"al foram efetuadas de minuto em minutos a deflexao nas ouvas nem sempre onrorponde ao vis lor mäximo.

A maionia da warks mostra apenas dois pioos endotërmicos, nas temperaturas $725-7250 \Leftrightarrow 895-9050 \mathrm{C}$ som

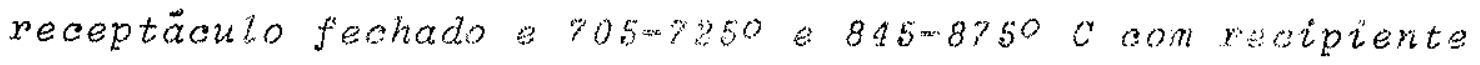
abexto. Esses maxtmos coxpespondem aos dois piss endotër micos da dolomita. embora Kulp e putros (1951)e Wolf e outros (1967) indiquem tempexaturas mais altas. As quatro a mostras restantes apresentam 3 picos endorémicos. a 6450. 705-7200 e 895-9050 C, nespectivaments. com reseptäculo fe chado, e 625-6450, 735m7400 e 810m8200 Cs com receptaculo a berto. Esses pieos orrezponden aqueles a ankeritas embo ra os trabathos consultados asininalem temperaturas mais a tas. As discrepanoias, em pates sa devidas a diferente taxa de aquecimento uilizada mas tambem podem ser conse quência da granubagäo do material analisado.

As anatises texmomdifsenciatss em combinacão com os indices de refracáo w dos arbonatos levam a con 


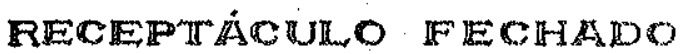

Am. C I

FRAGAO 60-100, MAGN. O, $-1,0 \mathrm{~A}$

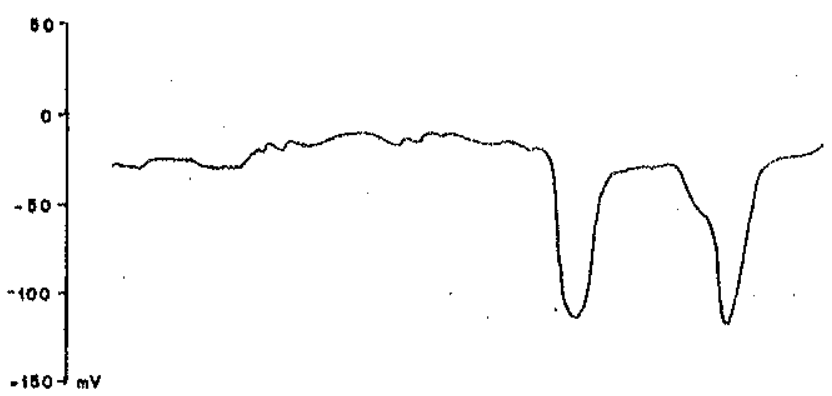

soo 400

Am. C 9

FRACAO 6O-100, MAGN. 0,2-0,9A

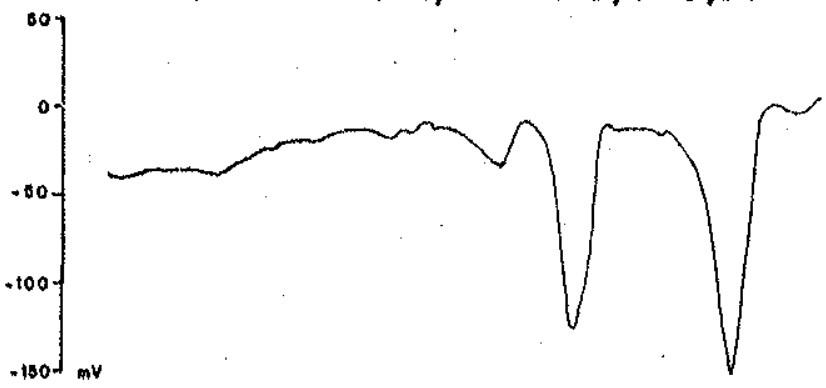

200

400

800

$+\infty$
Am, cis

FRAGAO 6O-10O,MAGN 0,7-1,OA

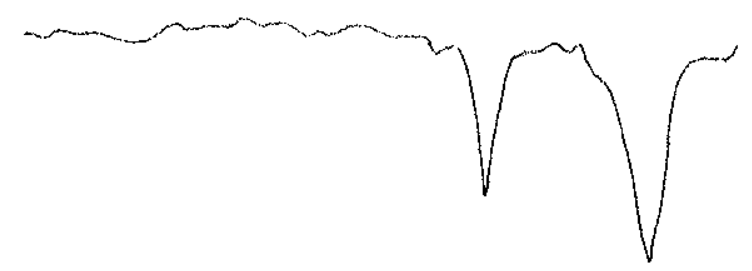

100020 $\$$ 800 800

Am.

FRACAO 6O-100, MAGN.0.2 - 1,0A

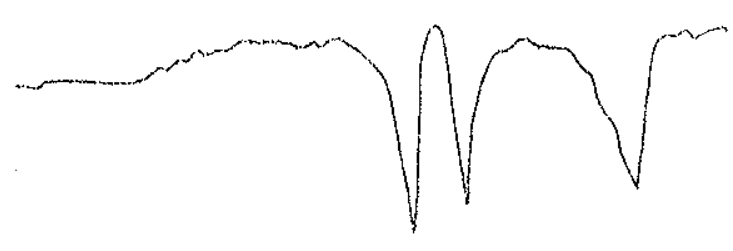

Arn. Ci4

FRACAO GO-100, MAQN $0,6-1,65 A$

Am. 5 s $-1 m 6$

FRAGAO OO-100, MAGN. O,3-1,OA

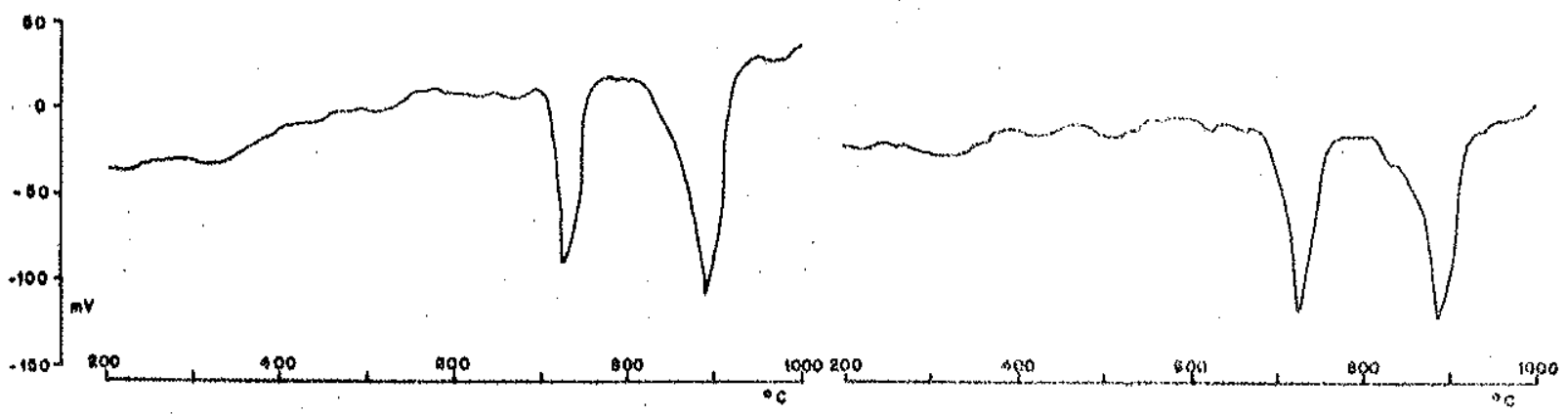

Figura : Tarmogramos de carbonatos do earbonatio do Juquiá. 


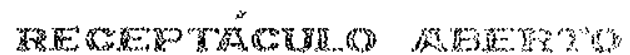

Am. 9

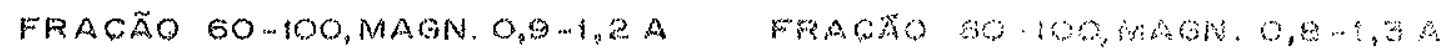

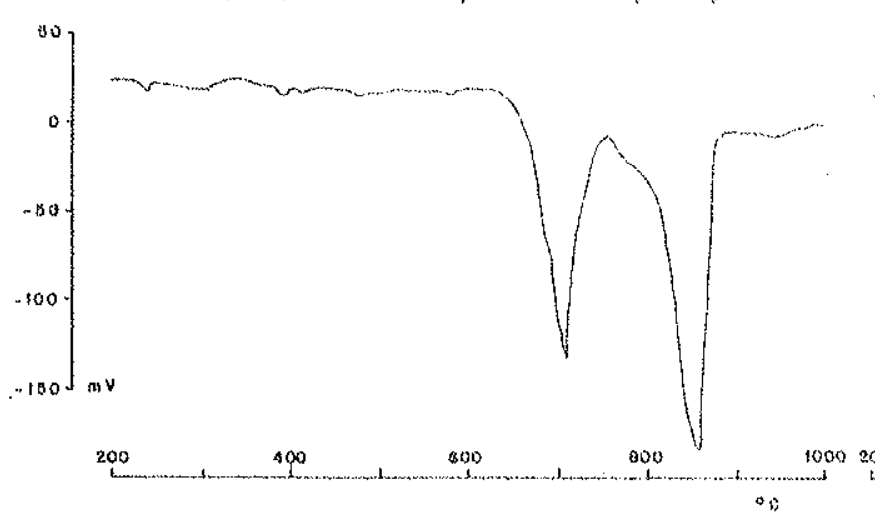

A, in.

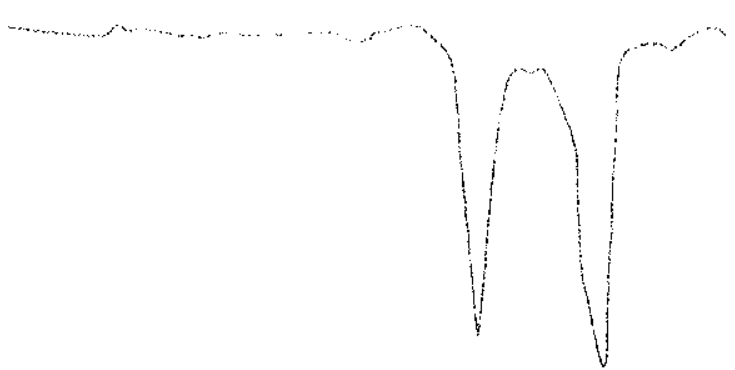

Arn, $\mathrm{Cr}$

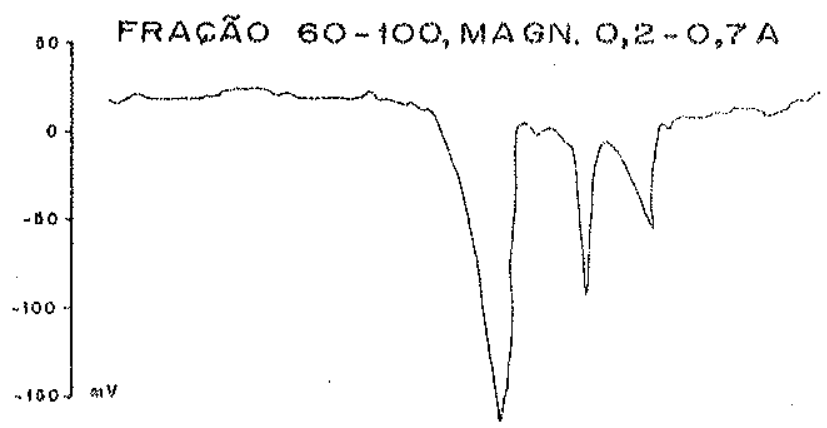

200

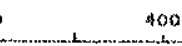

400

600

$\$ 00$ $10002(\%)$ ${ }_{0}$

Am.

FRACÄO 6O-1OO,MAQN.1,2 \%,6A
Ants

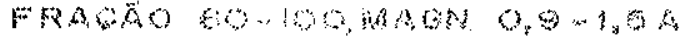

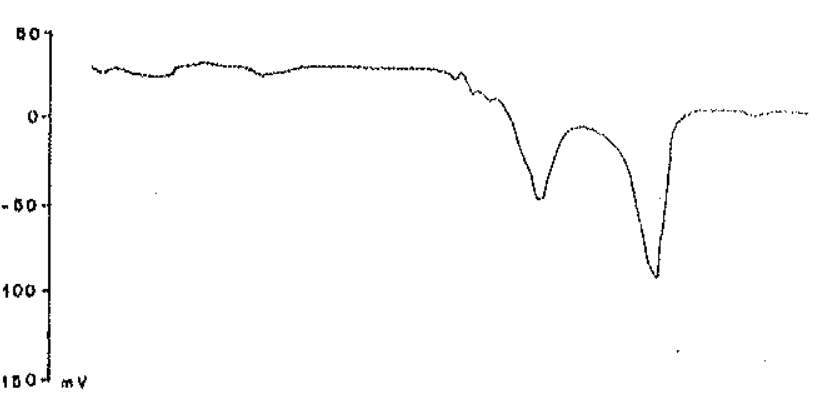

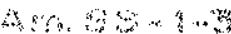

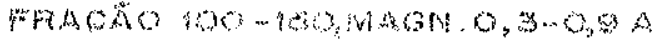

300 100 300 vis

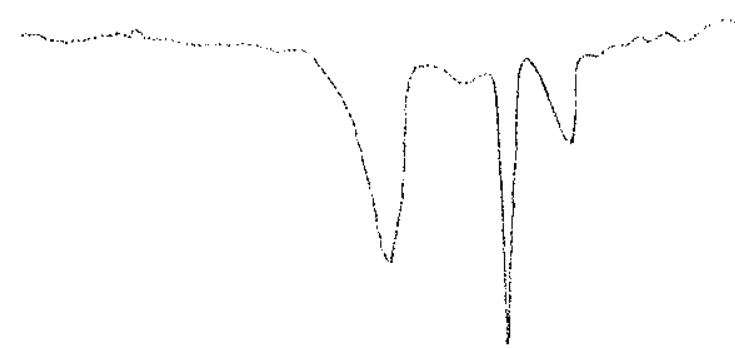
(3)

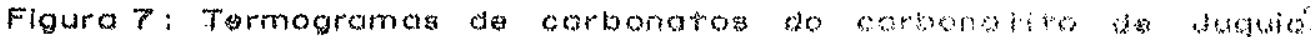


cluir que os têrmos ankeriticos estäo concentrados nas fra göes de maior susceptibilidade magnêtica; que, em geral pos suem côr mais escura do que a magnêsio-dolomitas entre max rom claro e marrom escuro. Uma unica amostra de alta sus ceptibitidade (SS-1*6) näo apresentou texmograma tipico de ankerita. txatando-se possivelmente de ankerita ou sideri ta decomposta em dolomita e ôxidos de ferro conforme jä havia sido indicado peto indice de refracäo. Nenhuma ană lise assinatou a presenga de magnesita pura, embora as anâa lises efetuadas com recepticulo fechado sugiram um possi vel pico, muito reduzido a cerca de $510^{\circ} \mathrm{C}$. Se existix magnesita pura, sua quantidade deve ser minima. os peque nos picos a $940^{\circ} \mathrm{C}$ nas anäises efetuadas com reosptaculo aberto, säo devidos a uma irregularidade da cuxva do "back-ground" e näo a presenga de calcita como se poderia supor.

Na maioria das amostras de carboratito foram efetuados testes de ooloracäo. os resultados revelaram-se extremamente insatisfatorios, pois não permitiram a identi ficasäo conclusiva dos tipos de axponatos presentes, mas apenas ressattaram a Zgumas areas por coloragoses diferentes. o procedimento seguido nos testes de coloragäo foi o indi cado por Warne (1962) e. em parte. Wolf e outros (1967). Um dos fatores que pode ter causado o insucesso dos testes ë a granulasäo dos minerais carbonäticos, gexalmente menor do que $0.4 \mathrm{~mm}$. Alëm disto. mititos carbonatos possuem con original marrom ou avermethada, mascaxando qualquex colora são adquirida. por isso, näo foi possivel reconhecex zo nas ricas em ankerita, identificada por outros mëtodos, ou siderita; alèm do mais, os testes com alizarina a frio,sem pre resultaram negativos.

Por êsses motivos, o uso de tiestes de colorasäo se restringiu a acentuacäo de certos caracteres textu rais, pois em varias roohas o tratamento com alizarina e NaOH-30\%, ou com ferpicianeto de potassio, provocou colora gão intensa de algumas zonas. Por exemplo, o uso de aliza rina e NaOH-30\% permitiu reconhecers pela forte tonalidade pürpura a existência de carbonatos, que em lämina delgada 
são turvos e escuross envolvendo manchas de outro tipo de carbonatos, näo coloridos. o teste com ferricianeto de po tassio, por sua vez, indica que a maior parte dos carbona tos brancos contem pequena quantidade de ferro, pois râpi damente adquirem coloragao azulada, existindo algumas manchas que näo mudam de cor. Warne (1962) ressalta que a in tensidade da coloragào azul näo è constante, nem indica va riação na quantidade de ferro presente. Algumas manchas de cormarrom, ricas em ferro segundo medidas de indice de refragäo, näo adquirem cox azul, presumivelmente devido a oxidaçäo do $F e^{+2}$ para $F e^{+3}$.

Excetuando os carbonatos portadores de bärio e estroncio, poderse dizer, com base nos testes efetuados, que a dolomita pura predomina seguida por ankerita e, por ütimo, parankerita. Se existir calcita, ela ocorre em quantidade e granulasao tao reduzidas. que não adquire im portancia, nem mesmo como acessorio. A presensa de carbo natos magnesianos puros naio foi reconhecida nos testes efe tuados.

\section{Magnetita}

A magnetita é o mineral acessörio mais comum e em algumas amostras perfic quase 5\% do volume, correspon dendo a cêrca de $9 \%$ em pêso. Ela estä associada a ilmeni ta e, possivelmente, maghomita e martita, mostrando, às vê zes, alteragão nas bordas dos gräos. Sua granulagão è va riàvel, desde muito fina ace $0.5 \mathrm{~mm}$. embora possa atingir $1 \mathrm{~mm}$ em alguns indivíduos isolados. A magnetita se apresen ta disseminada na rocha. cu entao em agregados, que podem se dispor em faixas orientadas, sugerindo textura fluidal. Muitas vêzes a magnetita forma octaedros perfeitos ou com faces parcialmente desenvolvidas.

Ilmenita

A ilmenita ocorre em associasäo com magnetita. 
na forma de lamelas de exsolugao finissimas e orientadas, que, em seçäo polida, podem atingir quase 10\% da årea ocu pada pela magnetita. A concentragăo dessas lamelas ë va riâvel, pois präticamente faltam em alguns gräos, enquanto são bastante comuns em outros. As lamelas de ilmenita podem ser identificadas pox meio de ataque acido a quente, res tando uma estrutura de finissimas placas oxientadas, prin cipalmente em gräos maiores de magnetita do solo residual.

A ilmenita tambem constitui placas mais grossas em algumas amostras de carbonatito, mas em especial, nos solos de alteragao, podendo ser separada por processos mag nëticos e ataque äcido. o material assim obtido muitas về zes se apresenta como um conjunto de placas superpostas, de côr preta, mas que adquire côx marrom por um possivel processo metamictico. Esse tipo de altexagão pode ser obserw. vado do longo de pequenas fraturas nas placas de ilmenita. A difragano de raios $x$ indica que o material marrom è um pro vâvel titanato de ferro (ralarelli, comunicagao verbal).

\section{Sulfetos}

Nas amostras de carbonatito da superficie, os sulfetos estaio em grande parte alterados. Nas amostras de sondagem, entretanto, apresentam pouca alteragão, formando manchas irregulares ou finos veios de ate $1 \mathrm{~cm}$ de compri mento, cujo principal constituinte ë a pirita. pirrotita e calcopirita podem ocorrer em quantidade muito subordinada, pois existem raros graos de sulfetos magnëticos ou com Ligeira iridescêneia.

os residuos nao magnéticos, obtidos no separa dor Frantz, com freqllencia contêm oristais cübicos de gale na em quantidades muto pequenas.

Em algumas amostras, principalmente de sonda gem, os sulfetos säo bastante comuns; na massa total da ro cha carbonatitica, no entanto, participam em proporsao mui to pequena, inferior a $0,5 \%$ 。 


\section{Barita}

A barita e̊ um acessörio comum, sendo posterior aos minerais que constituem a maior parte da rocha; ocorre em concentragões, associada a carbonatos de granulacão maior $e$ às vêzes idiomorficos, que preenchem veios e vazios na ro cha. Pode apresentar forma quase idiomórfica e granulacão de atë alguns milimetros. os grãos são translücidos a trans parentes. de côr branca ou entäo amarelada; em lâmina, a clí vagem e̊ bem reconhecivel.

Quartzo

Êste mineral năo se destaca pela abundância, em bora seja comum no residuo insolüvel ou näo magnëtico de vă rias amostras do carbonatito. Em lamina delgada, foi encon trado em casos raros. sendo nitidamente posterior aos carbo natos.

o quartzo, responsävel pela maior parte da silica encontrada nas anailises quimicas, ë mais comum nas a mostras de superficie do que em sondagem, podendo ter-se de positado a partix de solusöes percolantes superficiais. AI gumas amostras, cujos residuos näo magnëticos contêm pouco ou nenhum quartzo, apresentam teor relativamente alto de $\mathrm{SiO}_{2}$ na analise quimica, o que poderia indicar a presensa de minerais silicâticos.

Monazita

Monazita è encontrada com certa freqllências em aglomeragóes de minusculos cristais de côr verde clara a ama relada; preenche pequenas cavidades ou se distribui nas suas bordas, tanto em amostras superficiais como de sondagem. A monazita comumente estâ associada a oxidos de ferro averme Thados e baritas sendo tambëm um mineral tardio.

As aglomeragós de monazita säo constituidas pop prismas finissimos de distribuigao radial, dificilmente 
individualizados ao miorosoópio, mesmo com grandes aumentos.

Em uma pequena quantidade de monazita concentra da, efetuou-se medida de radioatividade, näo se verificario qualquer anomalias, que indiea a aǚéncia de quantidades no täveis de uränio ou rowio.

A identificaga do mineral foi efetuada por meio

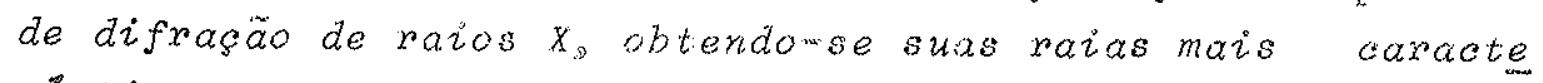
risticas.

\section{Gothita}

o mineral ancontrado como prismas mutto finos, dispostos radialmente nas bordas de cavidades e ao longo de fendas, sendo, portanto psstexior. Comuments estä associa da a monazita e carbonatos limpidos, apresentando cor maxrom escura. Em lamina delgada o mineral parece ser opaco. reve Iando-se transliucido quando examinado em lascas muto finas. sua identificasäo definitiva so foi possivel por in ismédio da difragão de raios $X$.

\section{Pirnoloro}

o piroclono constitui acessorio comum em algumas lâminas, embora seúa raro em outras; sua granulacäo pode atin gir 0,15 mm, mas em geral ê bastante menor. Em seçäo delga da, apresenta relévo mitio alto e freqliente secgü losangu lar, o que indica idiomorfismo; evtre nicois cruados apare ce quase extinto. o pirocboro ocorre disperso on em peque nas aglomeragoes, geralmerite entre gräos de carbonatios. Mine ral semelhante foi eveontrado no carbonatito exterro ( vide p.79).

os eristais de pirocloxo, isotados por moagem e separasăo magnêticas com muita freqllencia säo idiomorficos, constituindo octaedros perfeitos. Estes cristais säo incom lores a cor de mel, mas outras vezes possuem aspecto esbran quisado, pouco translüido. o pirocioro do Morro do serrote $\ddot{e}$ semeihante ãqueie descrito em Nkombwa (Gittins, 1966a. . p. 492) e Kangankunde (Garson, 1966, p. 64). 
Este minexal tambëm foi localizado nos solos do Morro do serrote, resultantes da decomposigäo dos dois tipos de carbonatito. Nesses solos o pirocloro ë encontra. do em cristais quebrados, mas tamberm em gräos idiomöricos. de côr branca a esverdeada, bastante friăveis: pode ser to calizado mesmo nos residuos insolüveis em HCI concentrado, quando o ataque näo ë muito protongado. o pirocioro dos solos näo foi estudado por meïo da difrasão de raios $x$, mas e possivel que esteja parcialmente transformado em pandai ta, variedade portadora de bario; esta alteragăo do pirow cloro è comum em algumas localidades congêneres, sujeitas a intemperismo intenso. os eristais de pirocloro encontra dos nos solos, em parte säo maiores que na rocha fresca.po dendo atingix ểra de $0,6 \mathrm{~mm}$.

\section{Aroylita}

Muitas amostras de carbonatito, à vista desax mada ou à Zupa. apresentam alguns gräos de um mineral de côr rosa-avermelhada. Im lamina, verificause que possui håbito alotriomorfico a idiomörfico e que estä associado a minerais tardios; frequentemente estä pouco alterado, adqui rindo entäo um aspecto turvo, que pode mascarax a cor de interferenciar quando cbservado a nicois oxuzados. A ancy lita ocorre em quantidade reduzida mas algumas vêzes $\vec{e}$ mais frequentes podendo formar pequenas manchas de cris tais intercrescidos.

Uma pequena quantidade dêsse material pôde sex separada e analisada por difrasão de raios $x_{s}$ obtendo-se as raias tipicas da ancylitas $\mathrm{Sr}_{3}\left(\mathrm{Ce}, \mathrm{La}_{0} \mathrm{o}_{4}\left(\mathrm{CO}_{3}\right)_{7}(\mathrm{OH})_{4} \mathrm{OH}_{2} \mathrm{O}\right.$.

Estronciarita, Norsethita

Possivelmente existe estroncianita associada aos minerais tardios, constituindo paxte dos carbonatos 2 im pidos, de granulagăo um pouso maior que a normal. Alguns dês ses gräos, encontrados no residuo näo magnëtico e com densi dade maior do que 3,27, säo biaxiais negativos, com änguzo. 
2V muito pequeno. Em observagăo räpida, podem ser confun didos com dolomitas que apresenta indices parecidos e algu mas vêzes e̊ biaxiaz. Uma pequena quantidade desse mate rial foi separadx e anailiada por difrasano de raios $x_{s}$ ob terdo-se as raias de un mineral identificado como provavel norsethita (BaMy $\left.\left(\mathrm{CO}_{3}\right)_{3}\right)$, haverdo, entretanto, raias que in dicam tambëm a presensa de estronciarita.

\section{c) Petrografia}

De um modo gerat, as rochas carbonatiticas po dem ser subdrvididas em dors grupos principais, calciticas e dolomiticas. respertiumente sbvitos e beforsitos segun do proposiga de Verwoerd $11968 \%$. independentemente do mo do de ocoxiencix. Esta sexia a oxientacão seguida neste tra balho, tanto pela simpliardade como por näo ser possivel afirmar se aigumas rochas ocoxrem em diques. Essa nomen clatura deriva da originalmente proposta por Broggex (1921) e modificada por vo Elekermann 11928 e 1948), que havia da do os nomes sbvito e rahaugito aos carbonaititos caloiticos e dobomiticos, denominando alvikitos e beforsitos as rochas de dique correspondentes. o nome dos minerais acessoricos mais importantes pode ser anteposto. quando convenientes por exemplo mieamsivito apatitabeforsito ainda segundo Vexwoerd (1966)。

Caxbonatito externo

Esto carbonatio foi encontrado apenas na son dagem efetuada na base a Morro do serrotes pelo Instituto Geogräfico e Geologico de säo Paulo. Apresentia textura sa caröide e granulagia gexamente mëdia entre 0,5 e $2 \mathrm{~mm}$. os minerais acessorios sio bastante raros. predominando mica e magnetita; a apatita oonire apenas em algumas laminas, foy mando coneentragoses aiongadas e orientadas com certo para teitismo dos gxass. ou em manthas irregulares. Nas pouras amostras em que estr. presertes a apatita e um acessörio fixequente e impoxtante. 
Nas laminas estudadas, os carbonatos nac apre sentam orientagios com execolo da amostra proventente de $82 \mathrm{~m}$ de profundidade, em que se nota nitido alongamento dos cxistais matores: o ativitamento desses gräos, no entanto po de ter sido rausado pata injegan de carbonatos finoss que substituem os constituintes originais. Estes carbonatos fi nos e de aspecto turvo, semethantes aqueles encontrados no carbonatito interno, tambern forom notados a profundidades menores, onde formam vetos em geral de espessura mutio re duzida, penetrando nos minerais primitivos e impregnando a rocha em redor com magnetita fina.

o carboratito externo, a julgar petos dados disponivetis, ex de cariter beforsitioo. A falta de amostras manuseaveis näo permitiu obter delathes sobre a distribuifio dos diversos minerais carbonatioos alem da citasäo de que testes de colorasaro som mitrato de prata e cromato de po tassio indicam manchas catoitivas pequenas e esparsas. con forme descrigao efietuada por lima em 1948 .

Dados de anctises quimicas de 25 amostras en tyo as profundidades de 42 e 67 metros na sondagem do $T_{0} G_{0} Q_{0}$ (Eelieiseimo Jx. 1968) "indicam a seguinte compom sigao:

\begin{tabular}{|c|c|c|c|c|c|}
\hline $\mathrm{CaO}$ & 31 & $a$ & 34 & $B a O$ & $0,2 a x_{2} 0 \%$ \\
\hline$M g O$ & 10 & $x$ & 15 & Mno & $0.2 \quad a \quad 0.7 \%$ \\
\hline$P_{2} O_{5}$ & 0,2 & $a$ & 4 & $\mathrm{SiO}_{2}$ & 0.2 a $3,2 \%$ \\
\hline $\mathrm{Fe}_{2} \mathrm{O}_{3}$ & 0.0 & $a$ & $2.4 \%$ & $\mathrm{SO}_{3}$ & 0.1 a $3.0 \%$ \\
\hline$A_{2} Z_{3}$ & $0_{.8} 2$ & $a$ & $\% .5 \%$ & $F$ & $0,2 \times y_{0} 0$ \\
\hline
\end{tabular}

Estes dados indicam que os carbonatos de Ca e Mg constituem mais do que 75\% dos componentes da rocha predominando a do lomita; tambem existiria, aindas ceria quantidade de caloi ba. Para os minerats asessorros encontrados em laminas os dados quimioos indicam desae tragos atë $9 \%$ de apatita; ate $1.5 \%$ de baxita e liw $2 \%$ de opacos. 
Carbonatito interno

O carbonatito interno possui caracteristicas variaveis de or e textura nas amostras provenientes de duas sondagens e de uma $i r$ a de afloramento, restrita ao cume do Morro do serrote. Os carbonatitos apresentam tex tura sacaröide e granulacao fina; os componentes de granu lasão mèdia säo raros. sendo oonstituidos principalmente por opacos, barita e. as vezes. earbonatos taxdios. maioria dos carbonatos como jä foi citado tem granulacáo da ordem de $0,2 \mathrm{~mm}$ ou mens.

As roohas apyeisentam dois tipos de bandamen to. Uma variedade e rarascerzada pela presenca de zonas ricas em minexais opacos, em earbonatito contendo poucos acessorios esmros. Histe bandamento sugere a existencia de uma textura fluidal ou planar. descrita em virios ou tros corpos carbonatiticos. o outro tipo, nitido em algu mas amostras e apenas indicado em outras, ë caracterizado pela presenga de faixas ixregulares de material carbonati co com coloxacáo digtimik fFotos 4 e 5 )

o estudo de cortes e de secgoes delgadas in dica que o arbonatito nase uniformes tendo ocorrido fa ses sucessivas de introdugao de carbonatos. Mais comum $\ddot{e}$ uma matriz de composicáo beforsitica. de corr clara e for mado por graos limpidos. rom frequentes minerais opacos. Nessa pximeira fase parea ter sido injetada uma segunda gerasäo de earbonatos maryom claros, mais ricos em ferro, contendo pequena quanitada de minerais opacos. Este ma ierial ocorre em manchas, as vezes alongadas, ou entäo pe netra por entre graos ou pequenas manchas dos carbonatos preexistentes $(\mathrm{C}=8$ e Cul. Lim raras amostras, ha evi dencia de uma texceira frse. formada por carbonatios de corr clara, injetada nas dias variedades anteriores. outro constituinte bem distinto sao os carbonatos de composisăo ankeritica, de cor marrom escura ou avermethada, que ooor rem em manohas irregularmente distribuidas (C-4 e Cos), po dendo tambem caracterizar bandamento muito nitido $(C-9)$. 
$-97=$

Foto $4\left(x I_{2} 3\right)$

Eoto $5(x) .2)$

Fotos 4 e $5:$ Bandamento em carbonati tos à enquiä. 
Nas lâminas verifica-se que a ankerita estä parcial ou tow talmente transformada em dolomita e oxido de ferros Este ú timo, parece ter sofrido ligeira migragăo, passando a im pregnar os minerais em redox.

As retaçes de idade entre os carbonatos escut ros e as outras variedades acima referidas näo puderam ser determinadas com seguranga. De maneira geral, em localida des congêneres, os carbonatos mais ricos em fermo - ankerim ticos e sideriticos sao considerados postoriores as fases calcitica e dolomitiva. serdo freqlente sua ocorrencia em diques (Verwoerd, $2966,0.131-132$ e p.176; Gittins, 1966b, p. 380)。

Em Juquiä, a ültima gerasão de carbonatos se caracteriad por mirstars himpidos e de granulasao bastante grossa, pox vêtes an gräos idionorficos, formando veios com espessura de poucos milimetros. Barita, ancylita, norsethi ta, quartio e talvez estroncianita estão ascociados a esses veios. A monaitia e os agregados de goethita, que ooorrem em vesioulas ou fendas paroialmente preenchidas, também es täo relacionados a esta geragäo.

Uma dus sondagens $(S, 5-1)$ atravessou uma rona de carbonatito mato rot eo pirooloro, onde esste minexal se apresenta wom sexta frequencia e em graos mars desevvolvi dos. facilmente identifia abei em lamina. Nessa mesma son dagem, uma amostra do caxbonatito possul aspecto bxechoide. pois material de granulaswo fina envolve pequenas manchas angulosas lambëm carbonatiticas.

Foram obtidas anälises quimicas de 15 amostrass de carbonatito e de dois dolomitos sitioosos do embasamento, afim de estabetecer as principais variagóes existentias. En tre as amostras de arrbonatito anazisadas 10 säo provenien tes da superficie e as outras 5 de sondagens (tabela g). In felizmente, verificouse que a preoisão das dosagens, em es pecial as de $\mathrm{Ca}$ a $\mathrm{Mg}$. deixa muito a desejar, tendomse obti do uma discrepancia de ate 30\% no teor de ca, em relaça a algumas dosagens mais presisas postexiores. De uma maneina geral, no entanto, as novas dosagens confirmam os attos teo 
SUPERFICIE

\begin{tabular}{|c|c|c|c|c|c|c|c|c|c|c|c|c|c|c|c|c|c|}
\hline \multicolumn{12}{|c|}{ SUPERFICIE } & \multicolumn{4}{|c|}{ SONDAGEM } & \multicolumn{2}{|c|}{$\begin{array}{c}\text { DOLOMITO } \\
\text { ENCAIXANTE }\end{array}$} \\
\hline & $c-1$ & $c-4$ & $c-5$ & $c-7$ & $c-8$ & $c-9$ & $c-11$ & $c-12$ & $c-24$ & $c-15$ & $s S-1-3$ & $s S-1-6$ & $S S-1-9$ & $S S-1-12$ & $S S-2-2$ & $D-1$ & $D-2$ \\
\hline$P . Z$. & 42,2 & 40,0 & 39,4 & 42,2 & 40,3 & $\leq 1,7$ & 41,4 & 41,2 & 40,0 & 39,4 & 43,9 & 42,7 & 42,2 & 44,1 & 43,9 & 28,4 & 24,7 \\
\hline $\mathrm{SiO}_{2}$ & 0,4 & 1,3 & 2,0 & 4,9 & 3,6 & 0,2 & 2,5 & 0,6 & 2,6 & 2,5 & 0,2 & 0,1 & 0,1 & $t x$ & 0,2 & 15,2 & 18,3 \\
\hline $\mathrm{Pe}_{2} \mathrm{O}_{3}$ & 7,1 & 10,4 & 9,2 & 2,9 & 4,1 & 6,8 & 5,8 & 6,8 & 5,9 & $.10,4$ & 6,2 & $5 ; 4$ & 7,2 & 4,6 & 3,4 & 0,8 & 2,4 \\
\hline $\mathrm{TiO}_{2}$ & 0,2 & 0,1 & tr & $t r$ & tr & $t r$ & $t r$ & $t+$ & $t 2$ & $t_{2}$ & $t r$ & $t x$ & $t r$ & $t r$ & $t r$ & tr & $t r$ \\
\hline $\mathrm{CaO}$ & 22 & 22 & 22 & 22 & 19,9 & 22,5 & 13,0 & 21 & 24,8 & 25 & 17 & 28 & 25 & 27 & 27 & 31 & 29 \\
\hline$M g O$ & 22 & 20 & 20 & 23 & 21,4 & 20,3 & 26,0 & 23 & 17,8 & 19 & 28 & 19 & 20 & 21 & $2 I$ & 22 & 20 \\
\hline$B a O$ & 2,8 & 1,6 & - & 6,1 & 4,0 & - & - & - & 5,7 & $4, ?$ & 1,4 & - & - & $4 ; 0$. & 8,5 & - & $<0,1$ \\
\hline 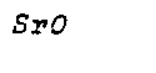 & 2,1 & $3,9 *$ & - & 2,1 & $4,2 *$ & - & - & - & 2,4 & 2,6 & 0,7 & - & - & 1,4 & 1,0 & - & $<0,1$ \\
\hline$P_{2} O_{5}$ & 0,6 & 0,4 & 0,6 & 0,7 & 0,7 & 0,5 & 0,4 & 0,5 & 0,8 & 0,4 & 0,2 & 2,8 & 2,9 & 0,2 & 0,4 & $t r$ & 0,1 \\
\hline $\mathrm{MnO}$ & - & - & - & - & - & 1,3 & 1,7 & - & - & - & - & - & - & - & - & - & - \\
\hline $\mathrm{MgO} / \mathrm{CaO}$ & 1 & 0,9 & 0,9 & 1 & 1,1 & 0,9 & 2,0 & 1,1 & 0,7 & 0,8 & 1,7 & 0,7 & 0,8 & 0,8 & 0,8 & 0,7 & 0,7 \\
\hline
\end{tabular}

Observacöes: Os dados relativos a CaO e kgo são aprozimados, pois ineluem parte do BaO e 5 ro, exceto nas amostias C-8, C-3, C-11 e C-14. As anälises exatas dessas 4 amostras apresentaram as seguintes variacões, em reiscäo aos dados aproximados deteminados anteriomente:

$$
\begin{array}{rrrrr}
c-8 & c-9 & c-11 & c-14 \\
\mathrm{CaO} & -2,5 & +0,7 & -3,5 & +1,0 \\
\mathrm{HgO} & +1,0 & -3,5 & -3,0 & -2,7
\end{array}
$$

* As dosagers de $B a O$ e Sro fora efetuadas posteriomente, por via ümide convencional, exceto o sr das amostras $C-4$ e $C-8$, dosados por aituizão isotópica.

Tabela 9 - Composigäo quimica de algumas rochas carbonatiticas de Juquiä e de dozomitos do embasamento. 
nes de $M g O$ relagäo Mgo/CaO elevada.

Essas anålises, consideradas imprecisas, indiam vatsres mitito altos de $A_{2} \mathrm{O}_{3}$, entre 1,3 e $9,2 \%$, o que $\ddot{e}$ impossivel em rochas carbonatiticas como as de Juquia. Con - luiture que os valores atribuidos a $\mathrm{Al}_{2} \mathrm{O}_{3}$ foram obtidos por diferenge, a partir do total de sesquiöxidos determinado. (meros ${ }^{2} \mathrm{~L}_{2}{ } \mathrm{P}_{2}{ }^{\mathrm{O}}{ }_{5}$ e $\mathrm{Fe}_{2} \mathrm{O}_{3}$ ). A maior parte dessa percentagem de $A_{2}{ }_{2}{ }_{3}$ na realidade deve ser $5 r O$ e BaO, que mais tarde fo ram dosedos em separado. Os dados obtidos para êsses dois owidos permitiram determinar a relaça $S r / B a$ (Figura 8), que noloca o arbonatito de Juquiă no grupo rico em estrôncio (yerwoerd 1966, entre p. 184-185), pois os teores, em geral, wäo superiores a $1 \%$. Tamberm a concentragão de bärio é consi derada abta.

Os dolomitos silicosos do embasamento se distin guem dos sarbonatitos, pela maior quantidade de silica, me nox perty a fogo e menor quantidade de ferro. Essas dife

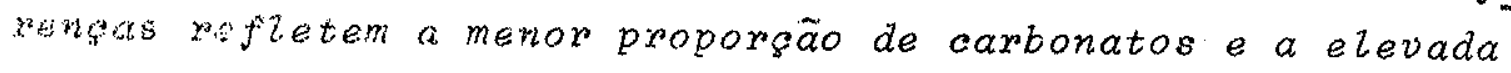
quantidade de silisatos, destacando-se mica, tremolita e aropsidio, alem da presenga de quartzo.

Noa caxbonatitoss $\ddot{e}$ de se notar que os valöres

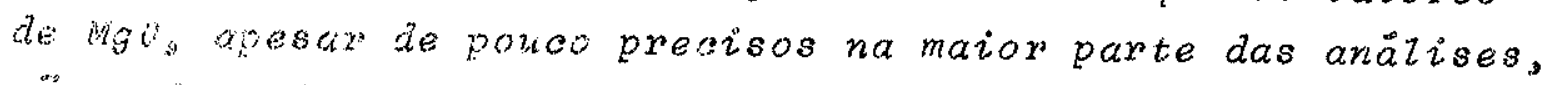
s. ma mo elevados, chegando a superar o CaO em mais de 10\%. Recaloularito os valöres de CaO e MgO para dolomita, verifica -se que quase sempre hä excesso de Mgo. Este fato, notadamen

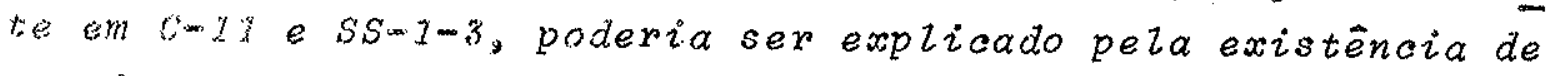
um minexal rizo em magnësia, como por exemplo, magnesita, hun titia ou bruolta; a ocorrëncia de carbonatito contendo breunneriza (magnesita ferrosa), como em Nkombwa (Deans, 1966, p.403). constitui uma outropossibilidade. Em lâmina, näo foi encon trada brucita, humita ou clinohumita, que poderiam explicar, en paxte, o oxcesso de MgO; alëm disso, os dois ültimos mine rais sausariam um aumento na quantidade de sizica, em espé uali nas ducs amostras mais ricas em magnësia. Heinrich 1966, $p_{0}$ 171) se refere à magnesita como o mais raro dos carbonatos romboedricos de carbonatito, afirmando que sua existencia foi aitada, mas naio comprovada, no carbonatito de Mbeya. 


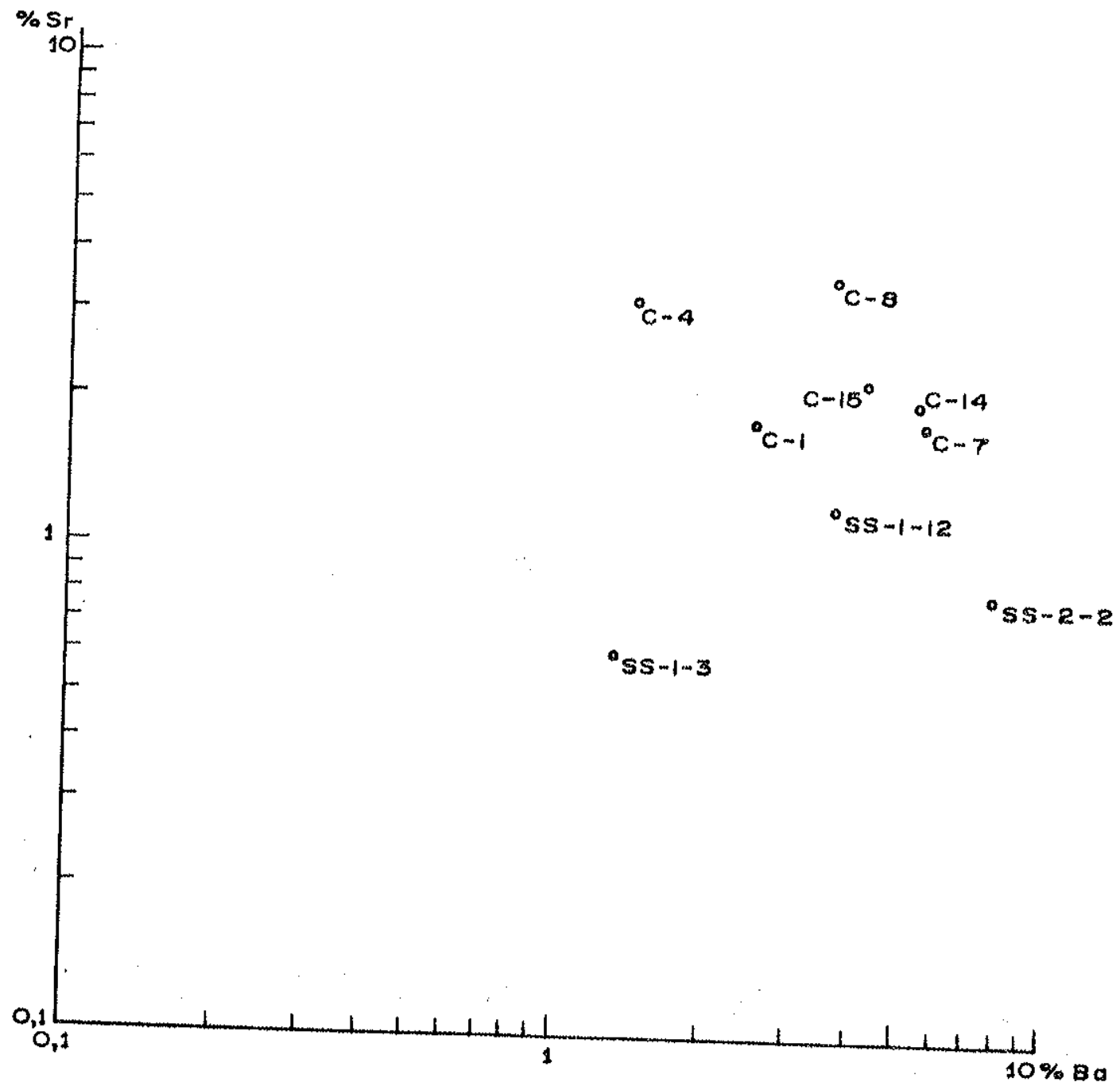

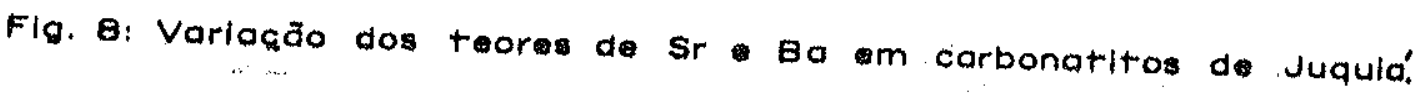


A elevada perda do fogo, quase exclusivamente devida a $\mathrm{CO}_{2}$ dos caxbonatos, pois a quantidade de ăgua con tida nas rochas ë muito baixa, indica que o excesso de mag nësio deve estar tambëm sob forma de carbonato. A possibi iidade de existência de huntita ê apenas sugerida, pois, sendo o resultado da alteracão de dolomita ou magnesita, po deria explicar o alto teor em magnësio, devido à relacäo de 3:1 entre $\mathrm{MgCO}_{3}$ e $\mathrm{CaCO}_{3}{ }^{\circ}$ Segundo Alderman 11959 , ef. cit. Wolf e outros, 1967), êste mineral talves apresente distribuigao maior do que normalmente se supöe. Como mag nesita e breunnerita $j a \vec{a}$ foram mencionados em carbonatitos, podem sex considerados a alternativa mais simples, apesar de năo texem sido identificados em Juquia.

Na bibliografia especializada säo raras as referências a carbonatitos muito ricos em magnesio, pois, mesmo nos beforsitos tipicos, a relasäo MgO/CaO náo costu ma sex muito alta. Entre as toaalidades que apresentam valôres altos podemos citar Mumbuto. Nachomba i Baileys $1966, p \cdot 145)$ e Kangankunde (Garson, 1966, p.65):

\begin{tabular}{|c|c|c|c|c|c|}
\hline & $0 / \mathrm{CaO}$ & & $\mathrm{MgO} / \mathrm{CaO}$ & & $\mathrm{MgO} / \mathrm{CaO}$ \\
\hline & 0,39 & & 0,66 & & 0,76 \\
\hline Mwambuto & 0,56 & Nachomba & & Kangonkunde & 0,62 \\
\hline & 0,78 & & 0,46 & & 0.59 \\
\hline
\end{tabular}

Uma excegào ocorre em Lueshe, onde as rochas magnesianas apresentam sempre mais que 30\%, atë um maximo de $90 \%$, da molëcula $\mathrm{MgCO}_{3}$ (Meyer e Be̊thune, 1960, p. 30\%). Entretanto, esses autores tambèm nao identificaram o mineral magnesiano.

Em Juquia, a relacá Mgo/CaO varia entre 0.2 e 0,5 no carbonatito externo rvalores mäximo e minimo pos siveis segundo dados de Feliaissimo Jr. - vide p.95; nas amostras do carbonatito interno, no entanto essa relacăo $\rightleftarrows$ muito mais elevada, pois varia entre $0,7 e 2,0$, sendo su perior a 1 em varios casos. Uma anditse quimiea paroial. citada por Knecht e Felicissimo rr. (1939, p. 21), indica 
uma relagao de 0,6 entre os dois oxidos.

o principal acessörio do carbonatito interno

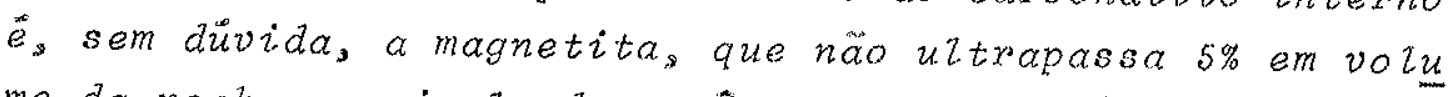
me da rocha, equivalendo a cêrca de $9 \%$ em pêso, em casos extremos. Alëm disso, parte do ferro indi゙cado pelas ană lises quimicas está contido em ankexita e em oxidos de fer ro secundärios. Verifica-se que os carbonatitos săo muito pobres em silica, portanto tambèm em silicatos, e que seu teor aumenta nas amostras de superficie, em relagä aquelas provenientes de sondagens. Possivelmente, isto é de vido a uma silicificagäo superrgena, portanto, independente da composicäo primäria das rochas carbonatiticas.

Algumas rochas apresentam elevado numero de pequenas cavidades visiveis a ôtho nu. As vèzes encontram -se monazita verde em pequenos tufos, tambem visiveis a vista desarmada, preenchendo êsses espasos. Êste modo de ocorréncia da monazita confixma a sua formagäo em estadio tardio da gênese do carbonatito.

A presenga de minerais de terras raras em carbonatitos, de prefexência beforsiticos e ankeriticos, em quantidades econômicamente exploraveis, foi verificada em diversas localidades, como Kangankunde, Nkombwa Hilis Wigu Hill, entre as pxincipais (Deans, 1968, p.402 e sem guintes). As rochas dessas tocalidades apresentam semethangas com o carbonatito do Morro do serrote, em espeoial com respeito a sua composigäo quimica e mineralogica. Essas semelhangas, entretanto, paresem ser mais acentuadas em relagao aos diques de carbonatito ankeritioo e beforsitico de Kangankunde (Garson, 1966). que posium uma serrie de ca ractexisticas similares a rocha de Juquia, excoto orean sa de apatita em grande quantidade e a assootacăo dos di ques a rochas carbonatiticas feldspäticas, frequentes no localidade africana. o carbonatito interno de Juquia. a jul gar pelos dados constantes da Tabela 74 ride p.155, aprem senta, entre os elementos de terras raras, ce e la em pro porsao bastante superior a $y$.

Minerais de båxio e estrôncio, principalmente. 
barita e norsethita, foram identificados em carbonatitos da parte interna. A barita constitui um mineral tardio, associado a caxbonatos de cálaio e magnésio limpidos e de granutasăo maior que a media dos gräos da rocha, quartzo oca. sional e monazita; outras vêses, no ertanto, a barita ocorpe em veios finos quase monomineralicos. Estroneianita, provà velmente, tambem estä assoaiada aos minerais tardios. Lises minerais de $B a$ e sx apareoem em proporcaio variavel, mas se gundo as anälises quimicas, podem atingix quase $10 \%$ em algu mas amostras. Em relagao a barita. verificoums que ocorre em quase todos os residuos näo magnëticos e insolüveis de carbonatitio, mas em quantidades redusidas. Isto indica que boa paxte dos minerais de Ba $e$ sx podem constituir oaxbona tos fäcitmente solüveis. Teores altos de Bal em algumas amostras (Tabela 9) indiaam que podem existir conentrasoes mais ricas em barita e talver outros minerais desse elemento, como witherita e norsethita, no corpo carbonatitico in terno. Parte dos atomos de sx e Ba deve estars aindas em posigoes de la e Mg no reticulo oxistatino dos carbonatos mais comuns.

A densidade das rochas varia entre 2,82 e $3,77$. em 9 amostras do carbonatito interno. 0 valor médio ef 2,96, baixando para 2,93 quando se exolut um valox muito alto de uma unica amostra, enriquecida em minerais de estronnoio e outros de pesso especifico elevado. A presenga de minerais acessörios em quantidades modestas é indieada pelas denstida des bastante uniformes da maioria das rochas, priximas a den sidade da dolomita e ankerita na amostra de densidade mais elevada $(\mathrm{C}-12)$, o residuo näo magnétroo oooxre em maior quan tidade e e rico em um mineral identificado como norsethita $(d=3,81)$, mas ê pxovavel que tambem exista cerba proporgao de estroncianita.

os solos resultantes da decomposigao dos carbonatitos, notadamente na parte superior do horro do serrote. apresentam öxidos de manganés. em gerat associados oom oxidos de frrro e magnetita; constituem blocos de dimensous varia veis, que em alguns locais recobrem a superficie. Im arande 


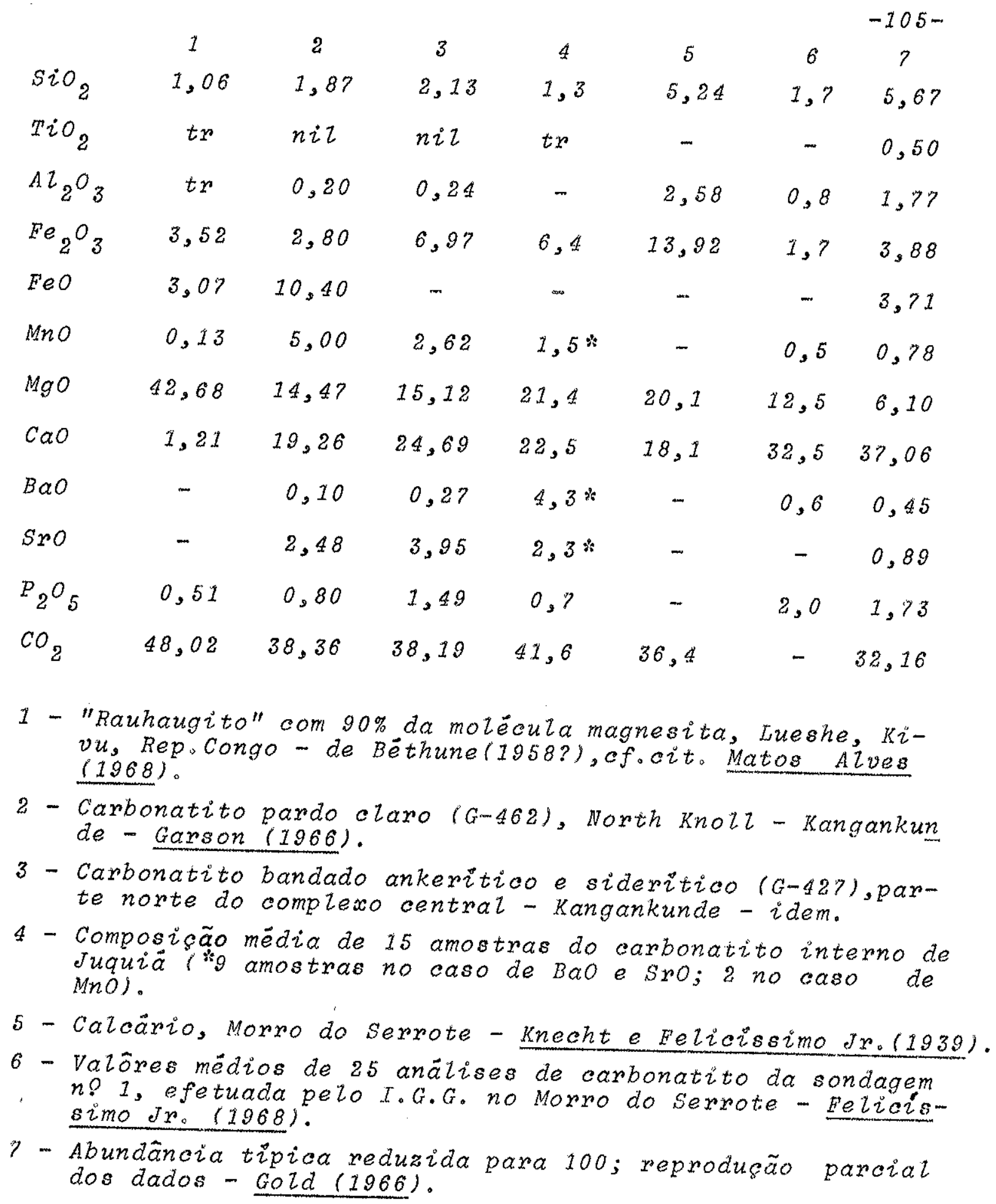

Tabela 10: Composigäo quimica de carbonatitos ricos em magnësio 
parte, êstes oxidos devem ser oriainärios de carbonatos com ferro e manganês, especialmente ankerita manganifera. Duas amostras do carbonatito de Juquia apresentaxam 1 e $1,3 \%$ de Mn na analise quimica.

A quantidade de fosfatos presente nos carbonatitos da parte interna ë reduzida quase sempre inferior a 1\% de $P_{2}{ }_{5}$ parte do qual estä na forma de monazita. Grãos de apatita acessória näo foram encontrados, embora devam o correr, possivelmente com granulasäo muito fina.

A Tabela 10 mostra a composigäo quimica de alguns carbonatitos ricos em magnessio. que näo parecem ser comuns pelo pequeno numero de citaços existentes; tambëm e dada a composigao média de 15 amostras do carbonatito interno de Ju quia, bem como os valöres de 25 anålises de amostras do car bonatito externo, provenientes da sondagem efetuada peto I.G.G. Esses dados säo comparados a abundáncia tipica dos oxidos. em carbonatitos provenientes de 55 localidades oal. culada por Gold (1966). o propxio autor ressalta que o nume ro de anaises quimicas disponiveis, parciais ou totais, muito restrito; alêm de abranger apenas uma parte das locali dades com carbonatitos conhecidas, superior a 150, ha grande predominancia de dados relativos ao sudeste da Africas segui do pela socandinävia.

Verifica-se que os carbonatitos da parte interna possuem teores muito elevados de $\mathrm{MgO}$, superados somente por uma anälise de Lueshe, sendo muito superiores aos valôres a pontados por Gold. Alëm disso, a quantidade de minerais aces sorios em Juquia parece ser muito inferior ao normal, confor me ë indicado pela elevada perda ao fogo e pela pequena quan tidade de oilica. Em muitas localidades com carbonatitos, parte da silica estä contida em minerais siliaäticos, nao i dentificados na ärea em estudo. 0 carbonatito externo, apesar de diferir bastante do interno, principalmente pelo teor mais baixo em magněsia, tambëm diverge dos valôres apresentados por Gold, por apresentar Mgo equivalente ao dobro da média. alëm de ferro e sizica muito baixos.

o significado dos valöres apresentados na compo 
sigao tipica de Gold ë interessante, mas tamberm disoutivel. porque étes nao sao realmente representativos de todos os carboratitos. Embora os dados quimicos referentes aos cax bonatitos brasileiros sejam raros e quase sempre incompletos. de intexesse estabelecer uma comparago com valores que re presentam a mëdia de numeroras aralises, ao invës de fazer comparastes com analises isoladas. No ainat grau de conheci mento dos carbonatitos, entretanto, talvez fosse conveniante tratar separax esses vatores medios em dois grupos phoos pobxas em magnesia, conforme uma subaivisaio freqlente das ro chas carbonatiticas. Esta subdivisao simples, mas ao que pa rece aracteristica, permitimia uma comparagao entro rochas de composigo mais semethantes bem como uma tentativa de es tabelever as jasidas minerats mais comumente assobiadas a $\mathrm{um}$ detominat tipo de rocha como exemplo, podese citay a maiar prequentia aparente de jazidas de fosfaios associadas a pohas arotiticas, bem com a ocorréncia de minerats de ter ras rars om assograga a rochas em geral magnesianas com o cumensy constante do numero de dados sobre carbonatitos. alem da desoberta de novas ocorrencias "tornamse cada ve: mars diftoit a comparasâ ertre as diversas looalidades.

Em retasao as ouras ocorrencias de arabonatito no Brasi?, powso estudadas em detalhe e com eseassos dados quimions disponiveis, podewse diser que os carbonatios de duquia apresentam o maior enriqueaimento em magnesio, alem de pobrea em minerais acessomios. Isto é valido especialmen te para o rarbonatito interno onde silicatos e apatita sao quase inexistentes. A presenca de freqllentes minerais de ter ras haras e barita. por sua wers é a aracteristica mais nota
wel.

A monazita e o pirocloro de Juquiä quase näo sao xadioxtimos, o que impede o estudo de sua distribuica por meio de medidas radiometrioas. Embora a anomalia oivitiométri olifexencie o Morro do sexrote das areas restantss. as amos tras individuais de carbonatito. de soto e um concentrato de monarita nau apresentam anomalias radioativas pereptiveis ou mensuraveis. Foi efetuada a medida da radioatividade de vo 
rias dezenas de amostras de solo, oxiundas de diversos to cais e profundidades, assim como das fracoes resultantes de separaga magnêtica, obtendo-se, no entanto, resultados prowimos wo "back-ground", com anomatias maximas de 0,5 e, muito raramente, 1 vez superiores ao nivel de fundo.

Quatro amostras de solo do Morro do serrote fo ram anaizsadas por radiometria nos laboratorios da comissäo Nacional de Energia Nucleax verificando-se valôres muito baixos $\left(0,007\right.$ a $0,015 \%$ equiv. $\left.U_{3} 0_{8}\right)$. A analise quimica da amostra com a maior anomalia radiométrica indioou apenas $0.001 \% \operatorname{U}_{3} 0^{\circ}$

A radioatividade muito baixas em amostras de mothas e nos minexais, principalmente monazita e piroctoro. náo constitui excegao, pois ja foi verificada em numerosas ocorrênoias congêneres; verificou-se que, apesar das massas carbonatiticas serem radioativas, as quantidades de uranio - törio presentes sâo reduzidas com predominânoia do segun do iDeans 1966, po 406-407). Uma pequena quantidade de concentrado de pirocloxo de Juquiă tambèm nào apresentou ra dioatividade anômala, tratando-se, portanto, de uma varieda de pobre em torio.

Como jà foi mencionado, entre as looxlidades oom arbonatitos no Brasi\%, as rochas de juquia sao, ate ago ras as mais magnesianas; no entanto, ainda existem diversas ocoprênoias muito mal conheoidas, em parte devido a cobertu ra por solos espessos, como peta fatta total de afloramentos. Jì al aispoe de anälises quitmicas, alëm de outros dados con cretos, sobre os carbonatitos de Jacupiranga, rtapirapuä e. em parte. Iparema e Catalao. Im Jacupiranga os teores $\mathrm{em}$ magnesio sco muito baixos nos dois tipos de carbonatito oo nheridos, diferenciaveis justamente pelo teor em Mgo; este se situa em törno de $1 . \% \%$ em mëdia, no carbonatito mais an tigo. em contraste aos $2,5 \%$ do coppo norte mais recente (Mejeher. 1965 e 1966a, po 176-179). Fim rtapirapua o carbo natito noore na forma de veios dispondo-se de algumas ana linses madais e de dosagem de elementos trago; a cabcita é

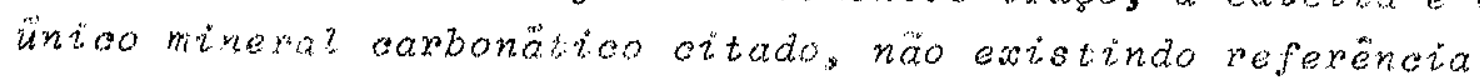


do beor de Mgo loomes $796 \%$ p. 77-81) Com respeito an cay

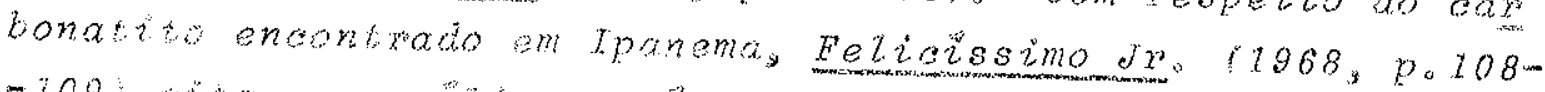

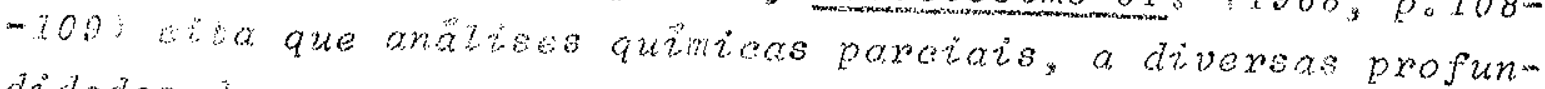
didades de umo nesma bondagem. indian as seguintes variagoes para alours siofos:

\begin{tabular}{|c|c|c|c|}
\hline$P_{2}{ }^{\circ}$ & 0.25 & $\alpha$ & $1,8 \%$ \\
\hline $\mathrm{Fe}_{2}{ }_{3}$ & $0,8 \%$ & $a$ & $9: 0 \%$ \\
\hline cao & 37,6 & $a$ & $53,5 \%$ \\
\hline 90 & 0,06 & $a$ & $1_{3,4}$ \\
\hline
\end{tabular}

\section{Esse mesmo autor tambëm nenolona composisan essenciat-} mente salctitua de duas laminas delgadas do oarbonatito com

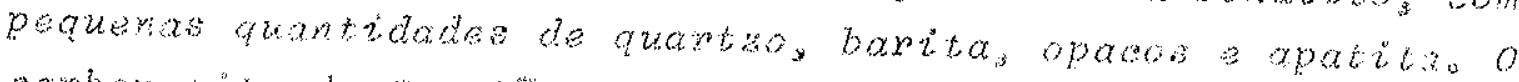

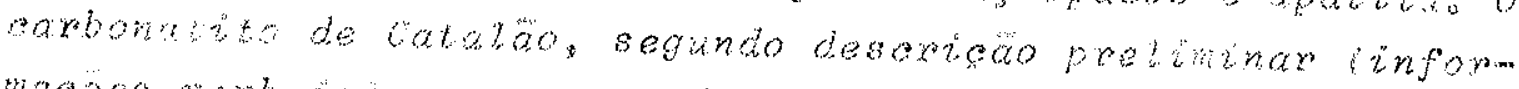

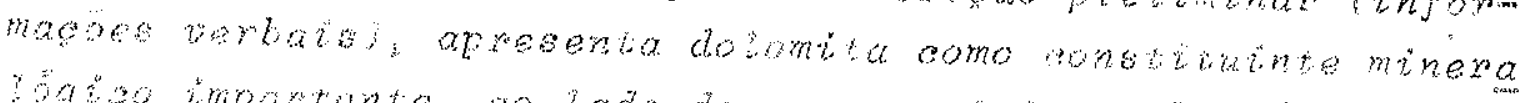

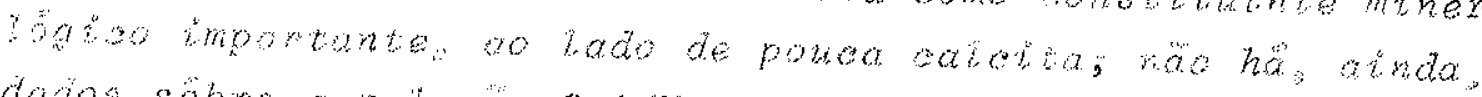
dados sobre a rataga callogo.

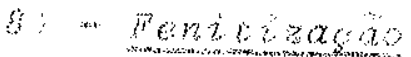

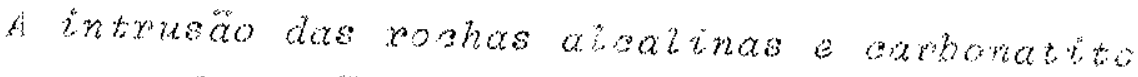

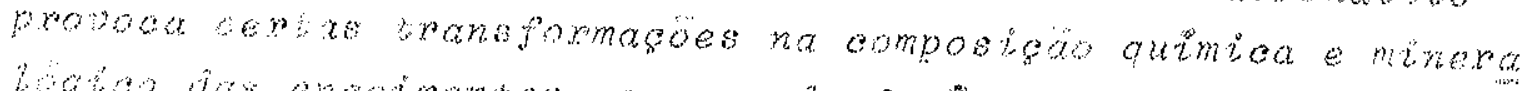

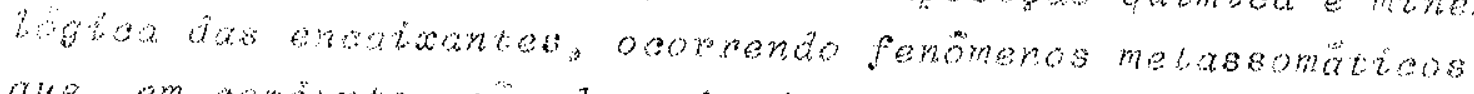

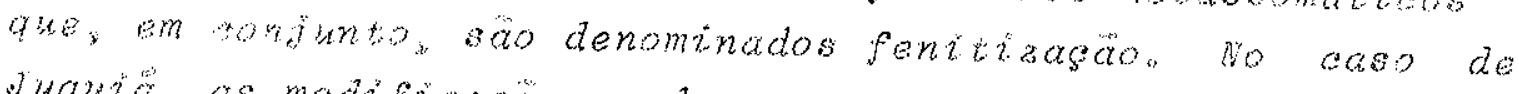
Juquer as modrfiagabes puderam sex estudadas apenas em rota

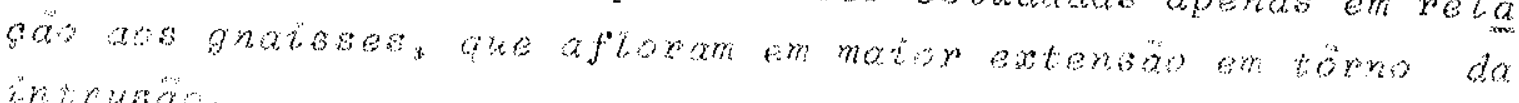
in thenan

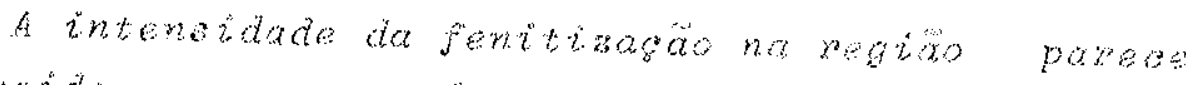

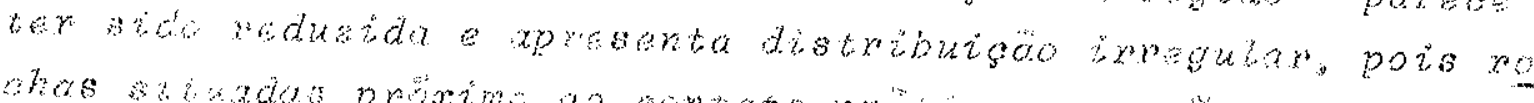

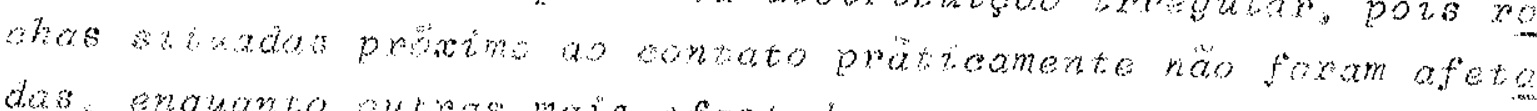

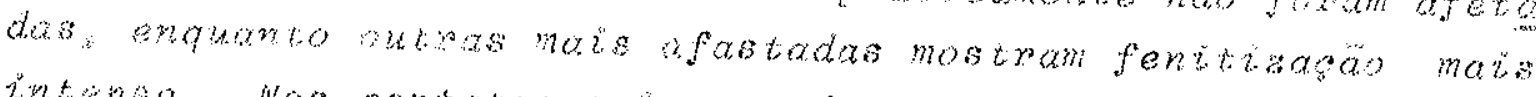
intwan wos contatos sut e nordeste entre as intrustrvas as encatamies, a existendia de fenomenos deste tipo nao pode? "ar wexificala por falta notai le afloramentos.

A fentitiasaro pode ser melhor compreendida o in

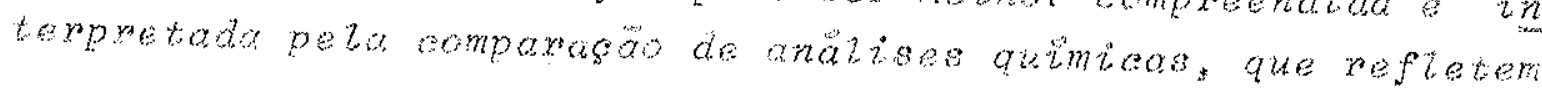


as modificasoes ocoxridas nas rochas; analises de minerais isolados permitem. ainda, reconhecer os fenomenos de adisáo ou perata de elementos nos diversos estadios de fenitizacá. sobretudo em feldspatos, piroxentios e anfibolios. Um conhe cimento adequado das rochas encaixantes originais tambëm é necessario pois elas nao apresentam composigao constante.

Em Juquiă, a falta de analises quimicas, tanto de encaicantes como de fenitos nä pexmite estabelecer va riasoes quantitativas provocadas pelo metassomatismo de contato. Devido ao pequeno numero de afloramentos, irregu laxmente distribuidos, nio se pode precisar a seqllência dos fenomeno: nem estabelecer um perfil que reflete o aumento gradual da intensidade de fenitizasao, a partir de modifi cagoes mineralógicas. o mapa geolögico (Anexo I) indica apenas os locais de coleta das amostras que apresentam in dicios de fenitizacáo.

Atualmente, se considera fenitizagaro qualquer modificasao ocoxida nas rochas encaixantes de complexos al calinos, devido a metassomatismo de contato; compreende des ae simples fraturamento dos graos ate substituigano total dos minexais, podendo inclusive, dar origem a outros ti pos de rocha. As novas variedades petrografieas assim for madas podem sofrer remobilizacäo totat ou parsial. A orien tagäo seguida pelos pesquisadores atuais és poxtanto, bem diversa da originalmente proposta por Brygger (1921); êsse autor reservou o têrmo fenito apenas para rochas alcalinas sienitioas, oxiginadas pela agäo metassomatica de fluidos. derivados de uma fonte alcalina magmática sobre rochas de composigäo aproximadrmente granitica. Muitos autores con sideram, inclusive, que varias, se nuto tödas, as abalinas Leuco e mesocräticas, se oxiginam por fenitizagao das en caixantes outros pesquisadores por sua ves atribuem xigem metassomáica a apenas aiguns tipos definidos; nesse grupo estico incluidos vo Eckermann (1966), King e Sutherland (1966) e Johnson (1966), para os quais as rochas sieniticas saio de oxigem metassomatica podendo ter sido remobilizadas. 
mostras, foram efetuados estudos sobre a fenitizacăo, em es peoial de gnaisses e granitos, em diversas ocorrencias de rochas alcalinas e carbonatitos. As conclusöes obtidas en contrum-se condensadas no trabalho de Vemoerd (7966), sendo ac nodificacies quimicas e mineralogicas analisadas em maior detalhe por Makie (1966).

As variagóes na composisao quimiea consistem tom adigao de alguns elementos e retirada de outros. $A$ in tonsidade dêstes tenomenos depende da distäncia da intrusấo : da composigäo dos fluidos fenitizantes, que agem de prefe mencia as longo de fraturas e juntas das rochas e dos minerais. Na fenitizagao ocorre, tipicamente, um enriquecimento em atralis, seguindorse em importância o Ca, havendo,por outro iado uma perda variavel de sio $2^{\circ}$ outros elementos, como $M_{G}$, le e Al, podem sex adioionados ou retirados, con forme as mranstâncias peculiares de cada intrusao 0 au mexto na quanitidade de aloatis pode significar um enriqueci mentr em $N a$ e $K$ ou apenas um dêseses elementos, sendo conhe idos casos onde ocorre perda de $K$ (Spitrkop - Strauss e rruter. 1951 e MeKte. 1966).

Pelas evidências mineralogiaas encontradas, po de-se concluir que a fenitizasaos em Juquiáa comportou-se de um modo distinto, em comparacáo com os fenomenos mais trowes olvalos na itweratura, pois verificoume que a for maga de minerais enriquecidos em Na é muito restrita.A ocox movia de anfibolio sobico, com seu maxcante pleocroismo a wadr, por exempto, reconheobdamente um dos minerais mais araderiatioos da fenitiacáa, mesmo em estadios iniaiais, esta restrita a diuas amostras. Em uma dezas, o mineral foi monntrado com eerta abundânoia, numa lämina delgada que mostro contato entre o sienito do Morro da Cada de Pedra a gnaisse unaicante; o anfibotio sodico é encontrado numa asa muito estreita, formando-se a partir de minerais mäfi oos prearistentes. No segundo easo, o anfibolio sodico $\frac{2}{e}$ anstrado em pequenas manchas muito irregulares, possivelmente formadas a partir de anfibolio preexistente; essas man whs oncriem de maneira esparsa, numa rocha composta por 
quartzo e feldspato, alëm de alguma de biotita, não afetada pela fenitiaasão. Pela sua raridade, o fenômeno não pode ser considerado comum em Juquiă, pois falta em numerosas ou tras amostras de locais muito proximos ao contato com a in trusäo.

Por outro zado, a formaçâ de piroxênio södico de cor verde, seja egirina ou egirina-augita, $\vec{e}$ muito rara nas amostras estudadas. Em outras localidades, este mineral costuma ser comum e $\vec{e}$ considerado bastante representativo de fenitizagäo: forma-se nas fases inioiais, ao longo de fratu ras ou fendas de rochas e minerais, enquanto nos estädiós mais avangados, passa a ser um constituinte importante da rocha. Em Juquiä, formou-se um piroxênio augitico quase in oror, que pode ser esverdeado, em rochas intensamente afé tadas pela fenitizasão. Em um üico caso foi encontrado $p \underline{i}$ roxento verde escuro, ao lado de alguma melanita. na parte central de um veio pouco espêsso, em oujas boxdas existe o priroxénio incolor, acima referido.

A existência de feldspato potässico, constituin do uma geracão mais nova, ê comum nas rochas pröximas ao con tato com a intrusão. Esse mineral, no entanto, faz parte da composigäo do gnaisse näo afetado e poderia ter-se formado por processos independentes da fenitizaçãos por êste motivo, năo pode ser considerado um mineral caracteristico do metas somatismo alcalino, a näo ser quando ocorre ao lado de outros indicios mais conolusivos.

Conclui-se que, em Juquiă, os fluidos fenitizan ces foram bastante pobres em $N a$, mas que a adigão de $K$ deve ter sido de certa importância.

Diversas caracteristicas petrogräficas, verifica das em amostras das proximidades da intrusäo, isoladamente näo constituem aspectos tipicos e conclusivos de fenitizasäo, pois podem se originar por outros processos, por exemplo, metamorfismo. Entretanto, sua localizasão em amostras de äreas marginais do complexo, sua ocorrência em faixas bem delimitadas do gnaisse e, principalmente, o desaparecimento ou 
redusao na quantidade de quarta das rochas, sugerem que war devides a fenitiagaxo apesos da fatta de evidencias dimetas e undubitäveis. como semia a presenga de minerais roos tom Na, en grande quartidade.

Entre estas sarateristicas podemos aitar o apryoumerto de grälos de quxtro muito fraturado e de felds patoo tuxpos no graisse. Alom disso, algumas laminas a prosertam velos irregulares cortando o gnaisse, constituido quase somente por quarto e fezdspato, com rarabiotita e anfibotio. Asses veios possuem minerais de granulagäo fi nissuma, entre os quais btotita marrom ctara a esverdeadas Whatho arredindados de espinelio de cor verde intensa.

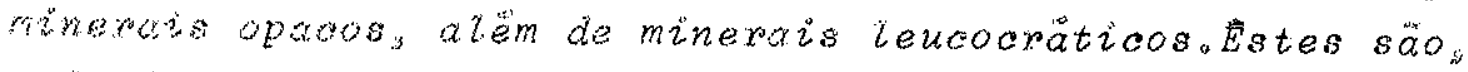
principabrients quartzo e feldspato albitico, que muitas vêzes constitum uma borda de graos limpidos, nos contatos com gnaisse normat. A presenga de espinëlio, em parte como gräo idiomóficos. indica atia temperatura nao con

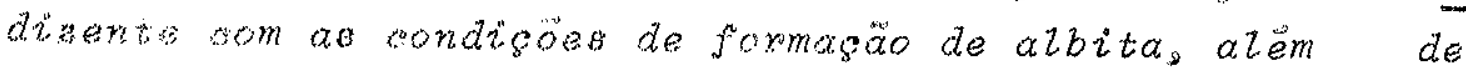
sex um minexat que nao pode coexistir oom quartzo. se estes wets we fomaram por altewago devido a metamorfismo de rontato com a intruea alcalina o espinëlio seria indica thio de atra ramperatura o que nato costuma ocorrer nos fenomenos de fentizacäo. Esse espinélio érioo em al e Mg a que parece, realmente houve adigá desses elemen tos em Tuquía.

Na borda sudoeste da intrusano, o gnaisse apre senta algumas faixas muito zrregulares, nas quais quartzo arandes aristar de feldspato, de aspecto turvo sao subs

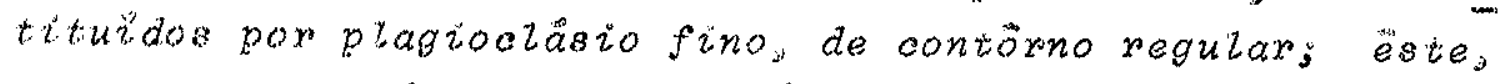
por sut we pode ser substituido por feldspato potassico. A datso minerais associa-se grande quantidade de grâs de prowenio fino quase incolor que podem formar aglomexa sobs, anfibolito verde comum. Biotitas de cồ marrom e de granuiasio mais pronunmiada, ocorre entre os outros mi nexais e muitas veases possui nucleo constituido por opacos. As relarob entre os tres minerais máficos sao obscuras, pois mutar verses o piroxenio parece se formar a partir do anfi 
bolio, enquanto em outros wasps sugere o contrário. Em al ghas amostas, o anfibotio torna-se raro, havendo grande quntidade de opacos e biotita ao lado de piroxênio quase inophox. Se estas faixas representam zonas de fenitizasão de grasse, as possiveis perdas e adisões de elementos säo incertas. coso cowespondam a faixas anfiboliticas feniti sadas apenas se pode dizex que houve perda de sizica. se, writetanto, a rocha era um gnaisse normal, constituido es senciatmente pox quaxtso efeldspato, a formagão dos minerats maficos impliearia sm adigà ao menos parcial, de ca, H. to talvez A\%. Entre os aloalis, a adicão de Na parece sex bastante modesta sendo o $K$ mais importante.

Outras tohas que podem estar relacionadas à fentiziago sto representadas pox très amostras bastante se melhantes de uma arye proxtma contato sul da intrusão wh an encaixaties. A amserm mais afastada da intrusäo a prsenta plagioclasion raros grass de quartzo, pouco piroxe wio de composigaro augrtica a algum anfibölio comum verde. $A$ mosta male proxima ao complexo contëm feldspato potassico sm hagar do plagiogikso. perat nefelina, grande quantidade de pryxelo augitioo satonho, sontendo inclusôes acicula yes rientadas, alem de algum proxentio e anfibölio avermethato. Biotita tamberm sempresta presente, sendo comum a aburdante. De uma manetra genexiox estas rochas podem ser

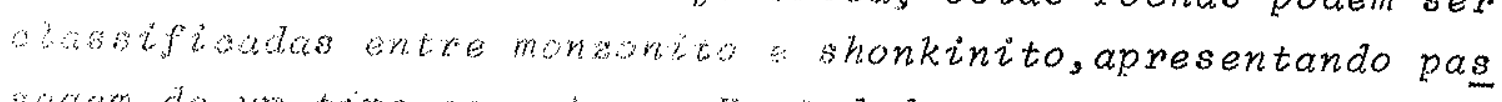
wagh de un tipo a who. Vhriedades com esta composigão näs poteriam ser diretamente retacionadas aos gnaisses, no whinto, podem constitulu roves que sofreram fenitizagäo in

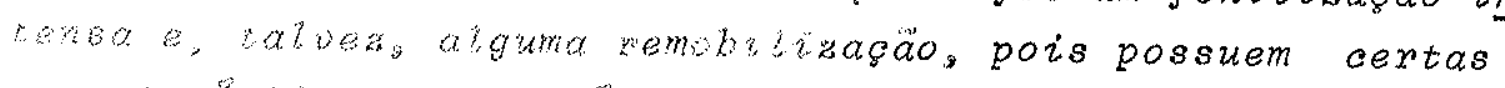

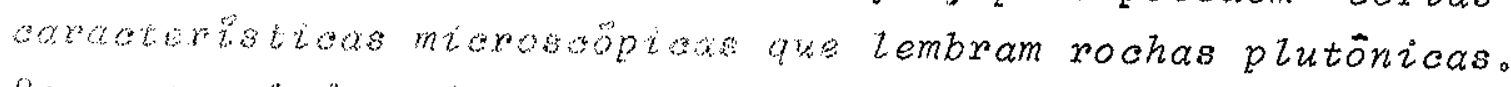
for auro lado, algumas indrages sugerem que estas rochas polewam ser consideradas hibridas entre uttrabäsicas e as whatantes opiginadas peza zssmizagäo de parte da encai wante gratsista pox matexial intrusivo. Mais uma veas faI

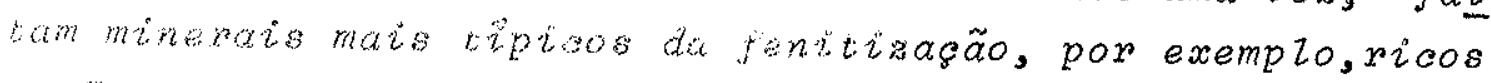
em Ha. mas pareoe haver um aumsto gradual de alcalinidade. A posibitidade da sua dewvagh de um materiat ultrabásico pares bavel, apesax de now sonhecerem exemplos seme 
Thantes na literatura; êsse fenomeno, alem disso, nao poderia ser incluido na fenitizagar, propriamente lita.

Varios autores (vo fickermann, 1961.1966 ;

Mekie, 1966, p. 261) consideram a fenitizagao relacionada apenas ao magma carbonatitivo por sua ves oxiginado de um magma azoalino siticatico. Atraves do estudo dos diques alcalinos de Alng, v. Eokermann 17961 , concluiu que o mate rial carbonatitico constitui uma capa no töpo a a coluna magmätica, sendo responsavez peza capacidade de ascensäo da mesma. Pela acão exeroida sobre as poohas encaisanbs do teto esta capa se tornaria cada ves mars caloztica am a resäo a superficie. Iniciamente esse autor supos que a intensidade da fentivagao batexat estivesse condiatonada a presensa da fase caleztica: a sua falta imptiaria por tanto, em pequena extensao laterat do fenomeno. Mats tar de, porëm, vo Eekermann 13966 , passou a considexar a inten sidade do metassomatismo fungoo do intervato do tempos du rante o qual o materiat carbonatiture exeroe sua asao robre as rochas encaixantes. Iista acăo seria mais protongada, e de maior efeito lateral, durarte certas pausas ra asoensto da coluna magmätica. A perda de gases. para rochas ercai xantes mais pexmeaveis. sexia una possivet expliaráo para a diminuigäo na capacidade de abxix oxminho para a superfi cie.

A vista dessa hipotese, aloumas consideragoes podem ser feitas sobre o material axponatitico de Juquias. essencialmente beforsitico e contendo quantidades inusiter das de MgO. Sua composigao dotomitica e a pobresa em mine rais acessorios, como biotita e piroxento coadunamme com uma zona de fenitizagá restrita possivelmente teria o corrido solidificacäo räpida "o material carbonatitioos de vida a uma queda de pressao.

9) - Relacoes de campo

o intemperismo intenso na regiao tem sido oi tado como o principal responsavel pelo pequeno numero de 
afloramentos, impedindo uma amostragem completa das divexsas rochas, bem como a determinasão de sua aistribuicäo no complexo atcalino. As poucas amostras de ada tipo de ro cha, por sua vez, näo permitem estabelecer com certea as diferenciagoes existentes dentro do mesmo grupo ou as rew lagöes com as rochas vizinhas. por este motivo, as conolu söes e relagöes discutidas a seguir. quanto do modo e sé qllência de colocacaro das rochas, se baseiam no estudo de seçöes delgadas, isoladas ou em conjuntos interrelactona. dos, às vëzes provenientes de locais afastados entre si. Tambëm se tevou em consideragáo a sequencia estabelecida em outras localidades similares. visando encontrar pontos de apôio que facilitassem interpretagoes plausiveis.

As rochas ultrabasicas ipiroxentio e peridoti to) e basicas associadas (gabros aboalinos) parecem ronsti. tuix o grupo inicial e de maior distribulcaso geografica e. ao que tudo indica, ocupam a parte externa do complexsyos terioxmente elas foram cortadas petos outros tipos de ro cha, com excefáo dos sientitos do Moxro da Casa de Pedra. Näo foi possivel verificar se os peridotitos e gabros alua linos constituem zonas definidas ou se eles sao apenas di fexenciasoes locais nos piroxenitos. os diques de composz são piroxenitica (lampröfixos) cortam as rochas aoima refe ridas, constituindo os termos finais da sépie máfica.

As rochas do grupo dos ijotitos sâ posterio res às utrabäsicas wotando estas. Wilas foram encontra das em algumas zonas resiritas e isoladas mas é possivet. que ocupem areas maiores. especialmente nas proximidades do carbonatito. Algumas dessas rochas devem ser diques, co mo sugere a constituigäo de atgumas amostras (Semioz Se-74).

A semethanga do que oooxre em loaklitades oon gêneres, a diferenciaga deve terme proeessado de pironenitos para ijotitos, com gradual enriquectmento em nefelina. Dessa maneira, ocorre um aumento na quantidade de alcalis. especiatmente de $\mathrm{Na}$. com diminuigäo de Ca e Mg; fato tam bëm confirmado pela presenca de egirinawaugita ou egimina. 
nos ijotitos, enquanto nos piroxenitos predomina augita. A existência de piroxênios com nucleo augitico e bordas de em givina-augita, nos ijolitos. tambèm è indiactiva desea se qliencia.

Os sienitos da area do Guaviruva e arredores. por sua ver, cortam as ultrabasicas e ijolitos sendo portan to posteriores. Esta relagxo e corroborada pela presenga de egixina-augita em amostras com caracteristicas de gabro aloa lino, na forma de agulhas em torno de piroxénio augivicos alëm da ocorrência de feldspatizasäo de ijotitos em alguns Locais. Entretanto. nao foi possivel verificax exatamente a extensäo dêsse fenomeno de feldspatiaacao.

As rochas sieniticas do Morro da Casa de Pedra constituem um corpo isolado circundado pelo embasamento In tretanto, pode-se admitir que sejam contemporaneas as outras variedades sieniticas de Juquiä, pois apresentam composicano bastante semethante. A uniea diferenga mais notavel reside no indice de agpaicidade mais baixo dos sienitos do Morro da Casa de pedra.

As ultimas manifestagöes da intwusao de rochas sieniticas são constituidas pelos diques de composisa simi lar, representados por nefelinasienitos e tinguaitos. Hisses diques em geral cortam os sienitos, mas alguns for am tambem localizados na area ocupada pox rochas ultrabasicas e; muito raramente, nas encaixantes.

A fase carbonatitioa em geral eonsiderada a ültima da sequência intrusiva com base nas observasoes efe tuadas em värias ocorrencias semelhantes, inolusive peia pre sensa de diques carbonatiticos cortando as outras variedades de rochas. Esta é tambem a sucessao admitida para os carbow natitos de Juquia.

Apös a consolidacao do carbonatito externo me nos magnesiano, ocorreu a formagao do corpo interno; em fases posteriores se formaram numerosos veios de barita e carbona tos tardios. Junto com ezes devem terwse formado os minerais de estrôncio, bem como alguns de terras rarass como a monazi 
ta e a ancylita. Deve-se admitir como muito provävel a exts tência de diques caxbonatiticos cortando as outras rochas do complexo, fato comprovado na maioria das ocorrencras congene res. A existência de pequenos veios com composisa equiva lente ao carbonatito interno, cortando o carbonatibo externo. foi verificada em algumas laminas de zadas e suporia a se quencia de eventos acima indicada.

As rochas carbonatiticas de tuquia formam um aox po definido, de contôrno arredondado ou oval, näo se conheren do em seu interior qualquer outro tipo de rocha Nas se sabe. no entanto. se cada um dos carbonatitos constitui uma massa uniforme ou vårios diques irregulares associados. Modos de ocorrência muito diversos säo citados nas descrisoes dos ons pos carbonatiticos africanos: no Matawi (Garson igob) e logrn da oriental (King e Sutherland 1966), por sxemplo. afloxum massas axbonatiticas com dimensöes e contornos mutio varia dos.

De um modo geral, o complexo alokino de eluquía se encaixa em um esquema de distribuigäo anelar e oncentriba dos seus constituintes; ijolitos e sienitos ooxam iryegrtar mente uma massa pxincipal constituida por roohas uitrabas cas, no interior da qual se encontram tambem os carbonatitos. pröximo a sua borda oeste. A associagäo de rochas indisa que a parte atualmente exposta deve representax um nivel profun do de um conduto vulcânico. Pela classificasäo preliminar dos complexos alcalinos proposta por Verwoerd il966) a dook rência de Juquiä se enquadra na classe das assooiagoes sub vulaanicas alcalinas, com pexidotito, piroxentio ijoltto. sienito e carbonatito. Entretanto parece disoutivel a pro priedade do têrmo subvutoanioo, a representantes de um nivel de erosăo profundo.

Em comparagäo oom os matores corpois carbonatitim cos conheoidos (Tweerivier, sukulu, Bukusu, entre outros, a ärea do carbonatito do Morro do serrote é muito modesta.

- caräcter magnesiano pronunciado dos carbonati tos, em espeaial o interno, alem do alto conteudo de sh $e$ 
Ba, poderiam ser tomados como indício de que a estrutura es tia exposta em um nivet relativo mais profundo do que racupi ranga, onde o carbonatito é marcadamente ataitioo. lista sugestäo baseiamse em anabogia com outras locatidades, por exemplo, Alns, onde w. Eekexmarn 1998 e 1966 j conetatou a existencia de dois fooos magmaticos distintos struandome o calcitico a profundidade meriv que o segundo dolomitiso. flëm disso, experiências de taboratorio wuli.e. 1960. p. 351) demonstraxam que a dolomita se forma a pressoss maiso res do que a calcita. sendo por isso razodvel suporowe maior estabilidade e concertratio de carbonatos magnesia nos a profundidades maiores dos endutos arbonatitios in tretanto, nao parece lizato aplizear as regras acma univer salmente. provavel ques alem do nive de exosos a com posicar primaxia dos fluidos wabonatitioos seja responsa vol. pelo menos em parte, peta oonstiturga final dos re presentantes atuatmente uxpotos ras diferentes boatudades. 


\section{IV - CARACTERISTICAS GEOQUIMICAS}

Do ponto de vista geoquimico, verificasse que as rochas da ärea de Juquïä pertencem à sërie aloalina de Peacock (1931), segundo o indice alcaliwealcico que ë de 42,5 (Figura 9). Segundo a classificagao désse autor. localidades com indice alcoli-calloico inferior a 5.7 perten cem à sërie alcalina. Almeida (1961) utilizas ainda, uma classe em separado para indices inferiores a 46; segundo essa orientagäo Juquiä pertence a sẹrie hiperalaalina. 0 valor obtido nesta localidade $\ddot{e}$ dos mais baixos entre os determinados em areas similares do Brasil: Gomes $11967_{*} p$. 92) obteve valor pouco superior para as rochas de Itapira puã $(43,5)$, inferior aos indices de Fernando de Noronha. Trindade e säo sebastiao. Em relagà ä ocorrencia alcali. na com carbonatito mais próxima Jasupiranga nada se pode dizer, devido à falta de dados quimicos referentes a essa localidade.

Para facilidade de comparagäo com a area de Itapirapuä, onde foi realizado um dos estudos mais desen volvidos do ponto de vista petrologico e petroquimico. den tre as ocorrencias alcalinas com carbonatito do Brasil. se rä seguido o mesmo procedimento utilizado por Gomes 129671. para indicar o comportamento quimioo dos principais elemen tos. Esse autor utilizou diagramas de variagáo, construídos segundo Nockolds e Alzen (1953). com o indice fëtsico de Simpson (1954) como base de projecăo. Elste indice è finido pela relagäo:

$$
F=\frac{\left(N a_{2} O+K_{2} O\right) \times 100}{N a_{2} O+K_{2} 0+C a O}
$$

As anälises quimioas (I'abelas 2,4 e 6 ), rela tivas aos piroxenitos, ijolitos e sienitos, tiveram seus valóres recaloulados para 100\%, em base cationica, excluin do ${ }_{2} \mathrm{O}$ (Tabela 11). Esses dados permitiram tragar os dia 


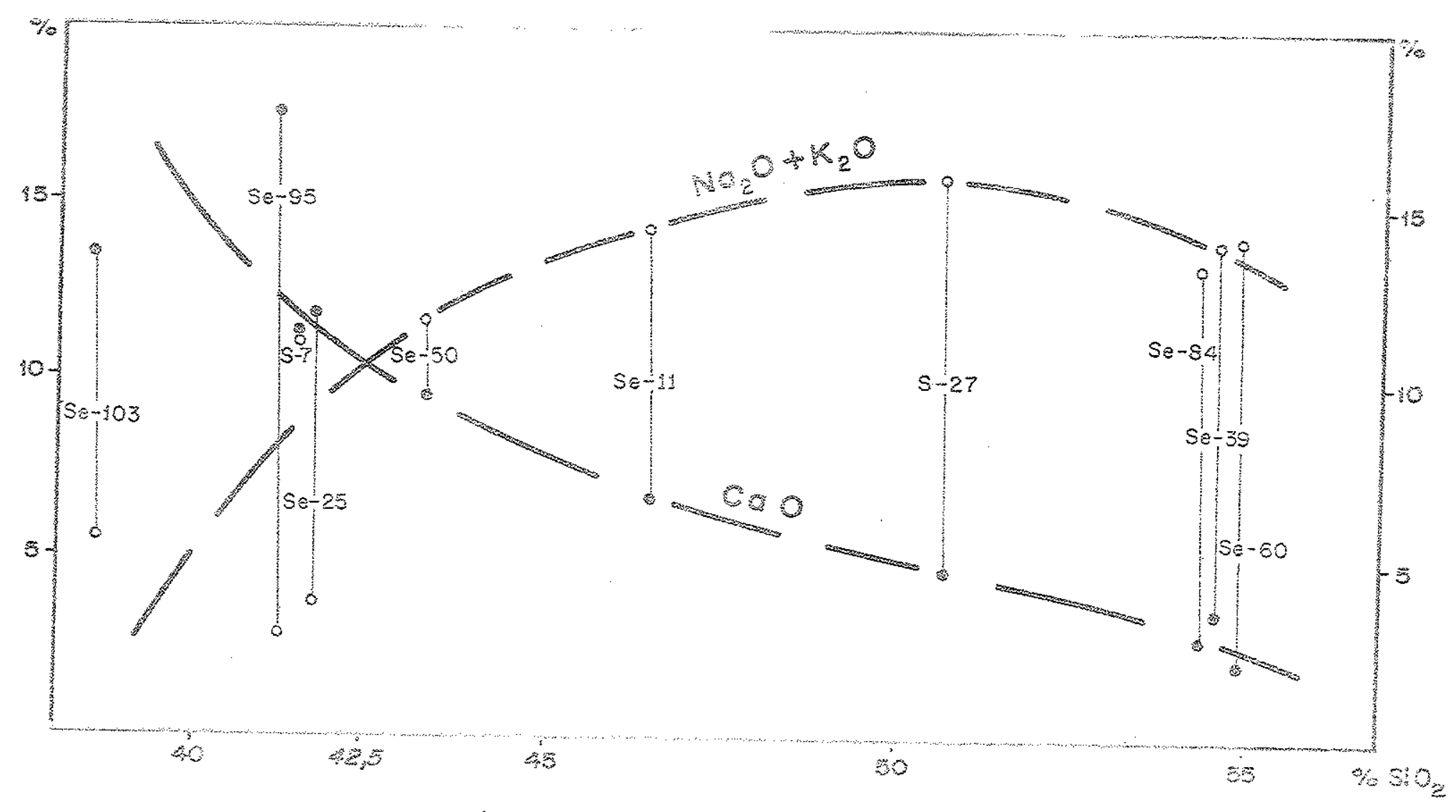

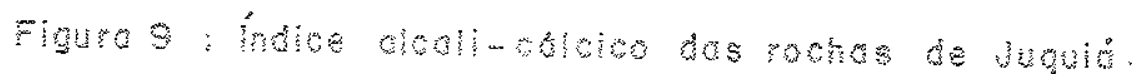




\begin{tabular}{|c|c|c|c|c|c|c|c|c|c|c|}
\hline & $\begin{array}{c}1 \\
s e-95\end{array}$ & $5 e-25$ & $\begin{array}{c}3 \\
S e-50\end{array}$ & $\begin{array}{c}4 \\
5 e-103\end{array}$ & $\begin{array}{c}5 \\
S-7\end{array}$ & $\begin{array}{c}6 \\
s e-60\end{array}$ & $\begin{array}{c}7 \\
S e-84\end{array}$ & $\begin{array}{c}8 \\
S e-39\end{array}$ & $\begin{array}{c}\theta \\
S e-11\end{array}$ & $\begin{array}{c}10 \\
5-27\end{array}$ \\
\hline$S i^{++++}$ & 19,53 & 19,41 & 20,81 & 18,30 & 19,72 & 25,95 & 25,83 & 25,77 & 22,04 & 23,90 \\
\hline$A 2^{+++}$ & 3,54 & 3,47 & 7,35 & 5,56 & 9,18 & 11,01 & 10,47 & 9,69 & 9,97 & 10,03 \\
\hline$T i^{++++}$ & 1,43 & 0,82 & 0,65 & 1,66 & 0,27 & 0,51 & 0,63 & 0,55 & 0,57 & 0,37 \\
\hline$F e^{+4 t}$ & 5,48 & 3,81 & 2,30 & 4,25 & 3,63 & 1,23 & 1,36 & 1,81 & 3,14 & 1,97 \\
\hline$F e^{++}$ & 6,19 & 7,47 & 4,46 & 6,24 & 3,27 & 2,40 & 2,66 & 2,46 & 2,37 & 1,64 \\
\hline$M g^{+4}$ & 7,20 & 11,78 & 5,37 & 7,89 & 2.88 & 0,36 & 0,37 & 0,58 & 1,19 & 0,94 \\
\hline $\mathrm{Ca}^{++}$ & 12,72 & 8,33 & 7.0 .2 & 9,76 & 8,18 & 1,56 & 2,02 & 2,54 & 4.89 & 3,39 \\
\hline $\mathrm{Na} a^{+}$ & 1,33 & 2,73 & 5,04 & 1,46 & 6,25 & 4,96 & 4,61 & 5,00 & 5,99 & 5,45 \\
\hline$x^{4}$ & 0,85 & 0,03 & 4,43 & 2,99 & 2,57 & 6,36 & 6,10 & 6,25 & 5,38 & 7,21 \\
\hline $0^{--}$ & 41,48 & 41,96 & 42,38 & 41,45 & 42,77 & 45,28 & 45,45 & 45,05 & 43,72 & 44.57 \\
\hline$F$ & 13,6 & 24,2 & 55,2 & 29,0 & 49,8 & 86,8 & 82,7 & 80,0 & 68,1 & 77,2 \\
\hline
\end{tabular}

Observagões: $0^{--} \dot{e}$ a diferenga entre $100 \%$ e a soma de todos os cations, incluindo $\mathrm{un}_{\text {, }} P C_{\text {s }}$ não constantes da tabeza.

Tabela 11 - Composişão química em base catiônica de algumas rochas de Juquiä recalculadas para $100 \%$, excluindo $H_{2} \mathrm{O}$ (Vide Tabelas $2,4 \mathrm{e} 6$ ). 
gramas de variagäo constantes das Figuras 10 e 11.

O compoxtamento das curvas ë semethanie para os elementos $5 i, \mathrm{O}$ e Al. seguido pelo grupo Fe, Ca e $M g e_{*}$ por fim, Na e k. O primeiro grupo apresenta aumento dos teores, das rochas ultrabäicas em dixegao aos sienitos, enquanto o segundo grupo se caracteriza por decréscimo acen tuado nessa seqtiencia. A quantidade de alcatis tambem an menta no mesmo sentido, mas as aurvas tem comporiamento mais irreguzar。

A relasăo si: 0 varia de um valor maximo l: atë um minimo de 1:1.75, no sentido das rochas máficas para as fërsicas: isto peftete aumento no conteudo de si, na pay te final da curva.

As curvas de fe totat e Mg mostram um comporia mento semethante, refletindo um decréscimo acentuado e uni forme dos teores, das rochas maficas em diregaro as feltiscas. No caso do $\mathrm{Mg}_{2}$ o teor variz de quase $22 \%$ a menos de $0.5 \%$.

- Ca tambèm sofre um forte deorescimo no mas mo sentido que os elementos antexiores, mas a curva represen tativa ë mais irregular.

A quantidade total de alcalis apresenta aumento. mais pronunciado no aso do $K_{3}$ o Na inelusive mostra de crësaimo na parte final da uxva dos riotitos para os siew nitos. Tsto se explica pela diminuigäo da quantidade de ne felina e egirinawaugita, com correspondente aumento de felds pato potåssico. A quantidade total de alcatis varia entre o minimo de $2,2 \%$ até o måximo de $12,6 \%$ 。

Conforme se pode verificar no diagrama triangum Lar Fe-AZK-Mg (Elgura 12). em tomparagaio com os dados de Gow mes 11967, po 96, fig。 20\%, do ponto de vista geoquimion, as rochas fëlsicas de Juquie tem compoxtamento simizar aquelas de Itapirapua. Na localidade em estudo existem, ainda varie dades máficas desenvolvidas, totalmente ausentes em Itapiram puă, o que resulta em teores de fexro e magnêsio muito supe riores em algumas rochas de Juquia. o maior numexo de anäli 


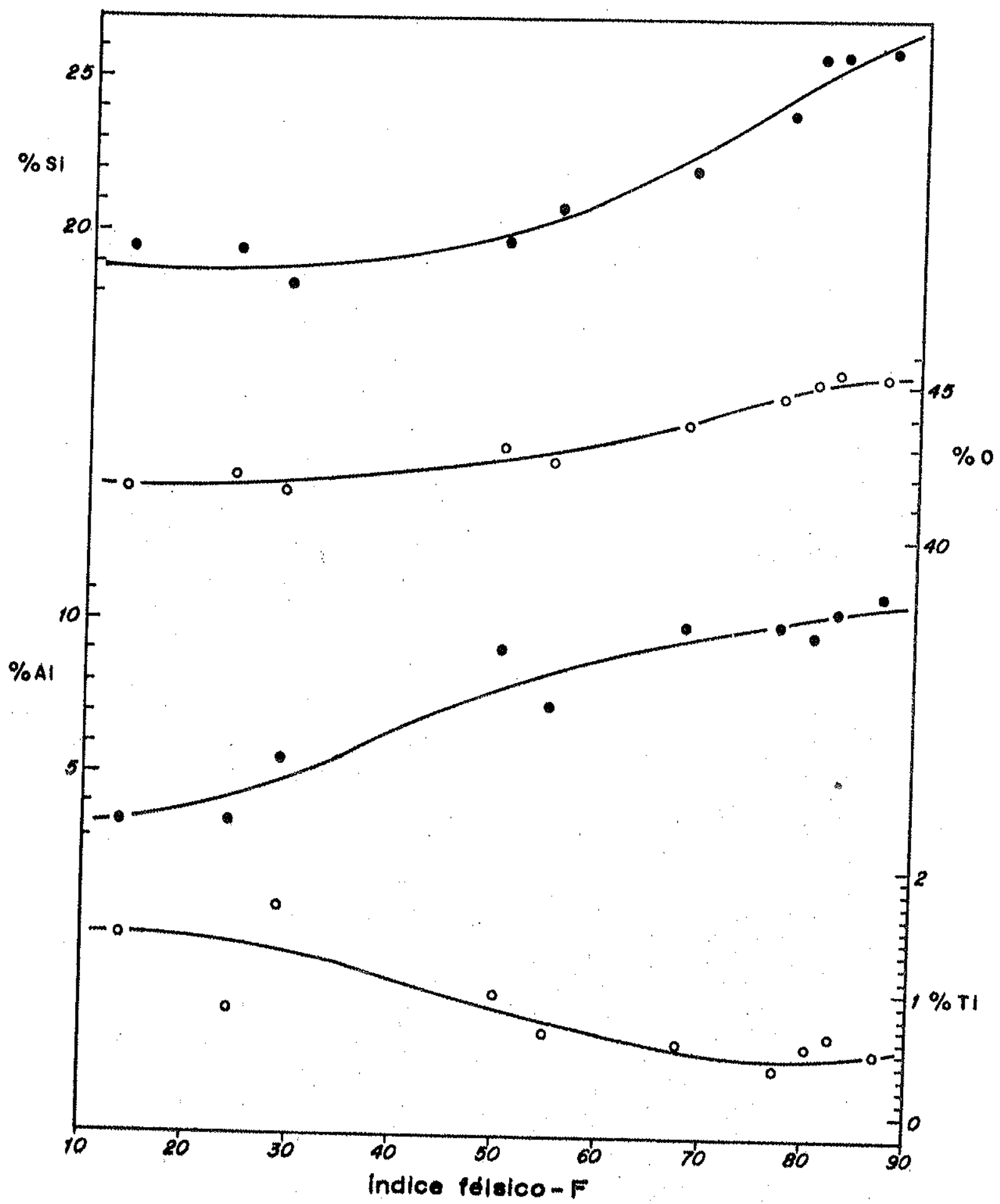

Figura 10: Comportamento geoquímico de alguns elementos nas rochos alcalinas de Juquid. 


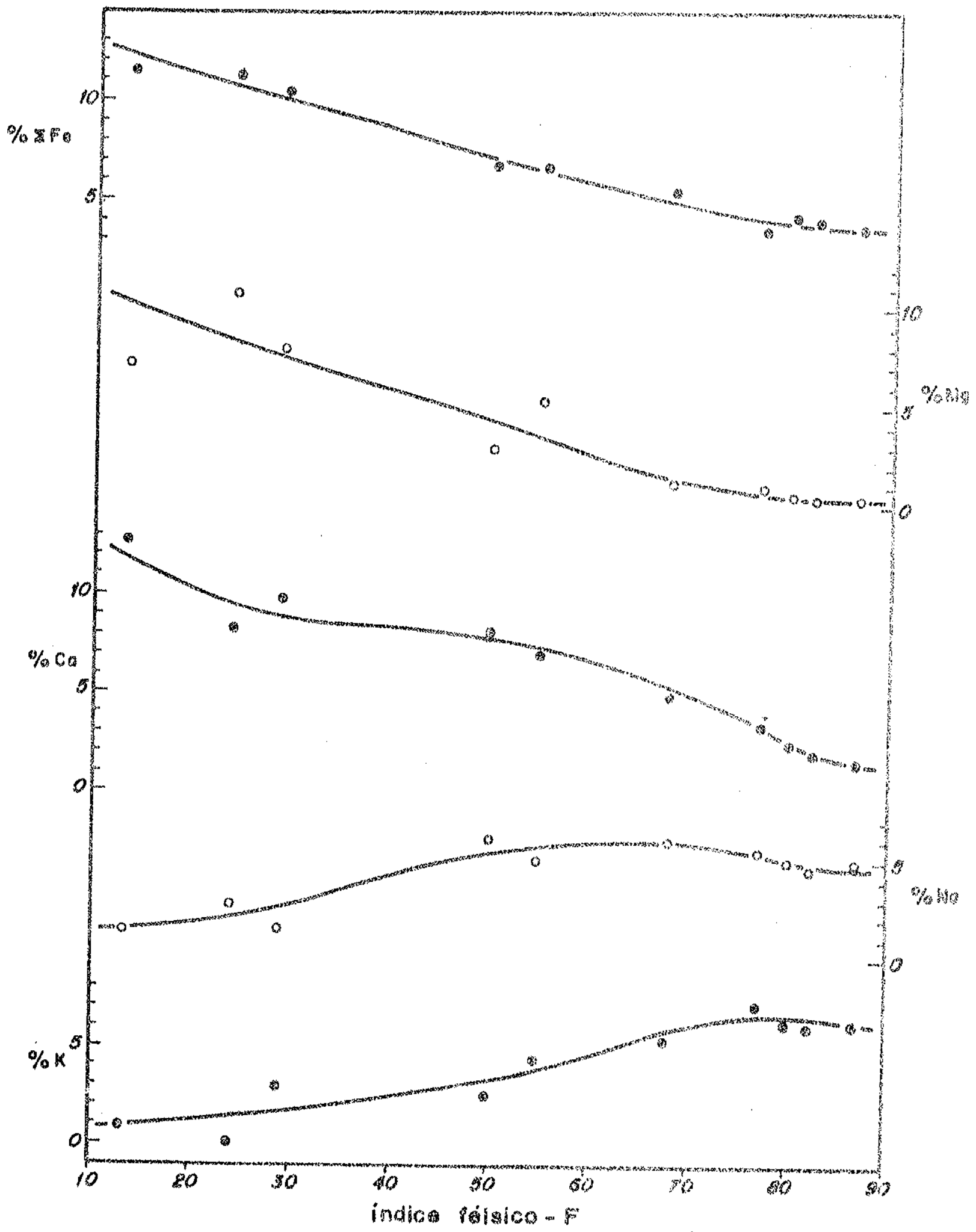

Figura 1?: Comportomento geonuínico de digums atomentos nos rochas alcalinas de Juquió. 


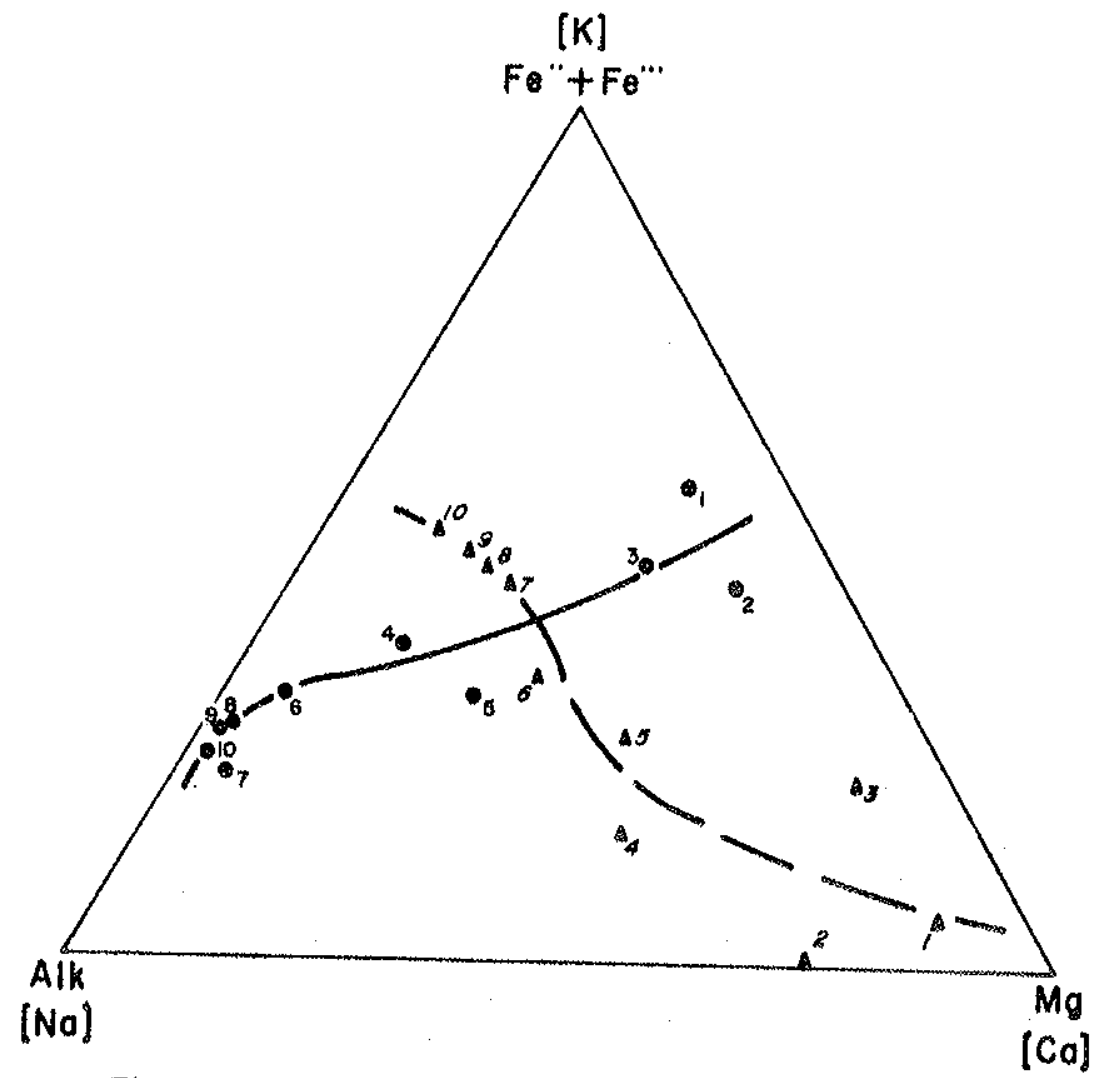

Fig.12 : Diagrama triangular $\mathrm{F} \theta-A l k-M g(*)$ $\mathrm{K}-\mathrm{Na}-\mathrm{Ca}(\mathrm{A})$ das rochas alcalinas de Juquiá, 
ses no a ampo intermediario deve-se ao fato de que reprssentan tes da semie ijolitica sáo mais comuns neste complexo obser

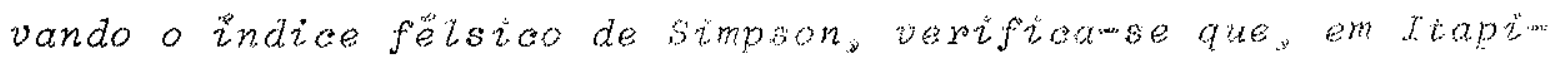

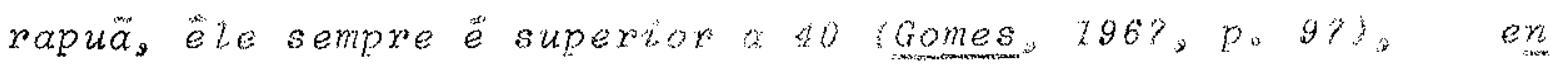
quanto as variedades uttrabasioas de duquta apresentam valsw res muito menores, oom um minto poweo superiox a lo lrabeta

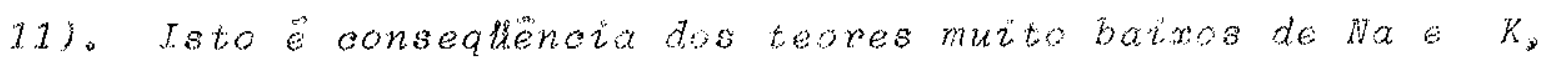
o mesmo acontecendo com rebaga ao Az.

$$
\text { possivelmente, Juqutapresente omportamento }
$$
mais semelhante a dacuptronga Meloher. $2954.1965 .1966 \mathrm{at}$

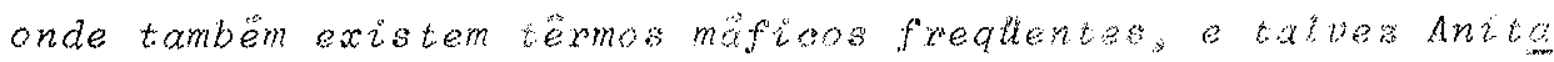

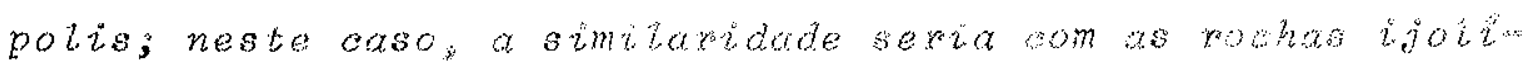
ticas, uma vew que os piroxenters sao muito restricos Melehter

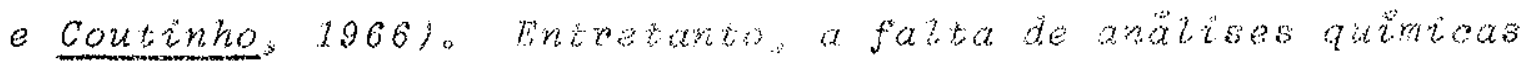
nessas locatidades impede qualauer osmparaga mats detazhada. 


\section{$V-$ GENESE E IDADE DAS ROCHAS}

Juquiä constitui uma ocorrência tipica de rochas alcalinas associadas a carbonatitos, apresentado uma sërie de caracteristicas comuns a numerosas localidades si milares do Brasiz e de outras partes do mundo. A falta de elementos de campo, petrográficos, geoquimicose isotopi cos não permite uma contribuicao oxiginal e significativa para a solucăo dos problemas genëticos relacionados a ro chas alcalinas e carbonatitos, em geral. Entretantos justi fica-se a analise dos dados disponiveis, para verificar em que medida êles se coadunam com as diversas hipoteses en contradas na literatura.

Os numerosos trabalhos existentes tratam dos mais variados aspectos geneticos, referentes às ocorren cias de rochas alcalinas. Im principio devese distin guir quatro problemas fundamentais, quando se discute a se qllência e modo de formagào dessas associacoes petrogräficas:

a) o primeiro diz respeito a interpretagao das relagoes de campo das rochas subsaturadas e silicatadas. bem como seu interrelacionamento, afim de verificar até que ponto a diferenciacäo magmätica pode ser considerada res ponsåvel pela origem dos diversos tipos petrograficos.

b) um outro aspecto se refere ao fenômeno da fenitizasauo, comprovado em numerosas ocoprências alcalinas, e de sua extensão, na tentativa de estabelecer a importan cia que as reacōes de metassomatismo e de assimilacăo de rochas encaixantes, pelo magma alcalino podem ter na for magäo de novas variedades litolögicas.

e) segue o problema da formacão das massas capbonatiticas, envolvendo sua origem e modo de colocagäo.

d) por fim, a mais difieil, ê a questäo do matem rial fundamental, ou seja, do magma parental que originou to dos êstes complicados processos e seus produtos. Alêm disso, devem ser considerados os aspectos geotectónicos e estruturais, que säo relacionados aos processos de formacăo dos complexos alcalinos. 
As numerosas ocorrencias atcatinas com carbonatitos, jä estudadas, forneceram um nümero de dados extre mamente grande, referentes as retacöes de campo entre as diversas variedades litologicas as caracteristicas petro gräficas e petrologicas, bem como analises quimicas inclu sive constituisáo isotopica e distribuisao dos elementos maiores e menores. Apesar de todos os dados disponiveis. atë agora näo foi possivel chegar a uma interpretacao uni ca e segura sobre a origem dos complexos alcalinos. como exemplo da complexidade do assunto pode-se eitar a teoria de Daly-Shand, que admitia a reagao de magmas com rochas carbonäticas. Mais tarde, outra teoria passou a sugerix exatamente o oposto, ou seja. assimilasao e reasao de ro chas encaixantes com fluidos carbonaticos para a formagäo das rochas alcalinas silicatadas.

Em relacáo a ocorrencia aloalina de Juquia.. poucas consideracoes se pode faser. com respeito a dife renciacäo magmätisa, prätiamente näo hä elementos. o com portamento dos prinoipais elementos no diagrama tranangular Fe-ALk-Mg e K-Na-Ca (Figuxa 12 ) indica uma queda pronun

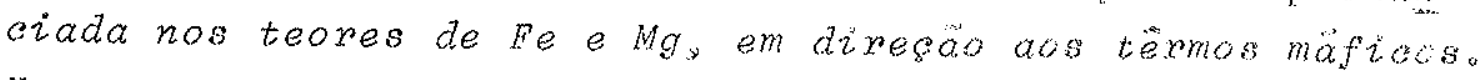
No entanto a rocha carbonatitica da localidade é muito rica em $\mathrm{Mg}$ com respeito ao Ca. o que seria um comportamen to anormal numa seqliencia de diferenciagáo pura e simples. os indicios de reagöes entre o magma original e as rochas encaixantes säo poucos e nada indica que elas tenham se dado em maiox escalas este comportamento entretanto, tam bëm ë comum em algumas outras localidades.

Quxnto à oxigem magmätica dos carbonatitos pa rece näo haver dividas. A composigäo quimica e mineralógi cas os elementos maiores e menores e a posicio do corpo caxbonatitico no complexo demonstram uma origem semelhantie aquela dos carbonatitos mezhor estudados. Duas determina sóes da relagáo $5 x^{87}, 5 x^{86}$ indicaram um valox médio de 0,7055 (Kawashita, comunicasaio verbal) em Juquiä, concordan te com os valores encontrados em carbonatitos (Powe iz e ou tros, 1966)。 
Sôbre o magma parental das rochas alcalinas de etuqui a, nada se pode dizer.

Duas amostras de rochas pertencentes ao comm plexo de Juquiä foram datadas pelo método potässiomargöm nio, conforme tëcnica descrita por Amaral e outros (1966). Um nefelina sienito apresenta idade de 14.5 .5 mithoes de anos paxa rocha total; enquanto isso, a biotita de um sie nito mostra $126,9 m_{0} a_{0}$ o feldspato da mesma rocha 159,0 m.a. (Amaral e outros. 1967). Uma idade mëdia em torno de 127 milhöes de anos foi preferida pelos autores. correspondendo ao Cretaceo inferiors na escala de tempo geolögico.

Como foi verificado em diversas zocalidades, entre as quais Pogos de Caldas e Jacupiranga. a intrusio das rochas pode se dar em diversas etapas, durante um tem po geologico bastante prolongado. o mesmo pode ter ocorm rido em relagăo a Juquiä, o que talves explicasse a idade mais elevada, aparentemente anomala, obtida para o felds pato alcalino (Amaral e outros. 1967. p. 134).

Pela idade em torno de 127 mithoes de anos, Juquia pode ser incluida no grupo de ocorrèncias aloalinas que compreende dacupiranga, Ipanema. Ttanhaem, etc. que apresentam idades entre 122 e $133 \mathrm{~m}_{0}$ a outro grupo bem mais recente, cujas idades situamse entre 52 e $82 m_{0} a_{0}$ (Amaral e outros, 1967), inclui a maior parte dos complexos a calinos de Minas Gerais e Rio de oneiro, alem das alcalinas do litoral norte de säo Pauto. Hasui e Cordani (1968) estudaram as rochas alcalinas do oeste mineiro e sul de Goiås, obtendo a confirmagäo de idades em torno de 80 m.a., para a maior parte das ocorrêneias, alëm de algumas de $70 m_{0} a_{0}$ (Tapira e Morro das Broas) e $90 m_{0} a_{0}$ (Axaxa). Corm dani e Hasui (1968) confirmaram tambëm uma idade intermedia ria na região de Itapirapua e Tunas por volta de 110 mo.s jä identificada na primeira localidade por Gomes e Cordani (1965). Com relacão à idade das rochas basälticas do sul do Brasil, situada entre 119 e 147 m.a. (Amaral e outross 1966), verifica-se uma boa concordancia com o grupo de alca 
Linas mats antigas. o mesmo nao acontece em relagäo às mais Juens. impedindo qualquer considerasao mais consistente. na tentativa de relactonar tôdas as rochas alcalinas a ativida de basaltica. 


\section{$V I$ - PROSPECSAOO GEOQUIMICA}

Em diversas localidades de rochas alaalinas e carbonatitos tem sido noticiada a existencia de quantidades apreciäveis de fosfatos, principalmente apatita. Esses fos fatos podem ocorrer em concentraeões nas rochas alcalinas silicatadas, disseminados nos carbonatitos ou em enriqueci mentos nos solos residuaís dêstes. Em algumas ocorrências africanas essas concentrasöes possuem significado economico.

No Brasil, êste tipo de depösitos possui im portância especial, uma vez que ainda não são conhecidas ja zidas de fosfatos sedimentares de grandes dimensões. AtuaI mente o unico depösito explotado em escala apreciävel, para a producão de fosfatos com caracteristicas adequadas à fa bricagão de fertilizantes superfosfäticos, ë o de Jacupiran ga. Tambëm em Araxă ocorrem jazidas de fosfatos associados a rochas alcalinas e carbonatitos. Dessa maneira, è öbvia a importância potencial da região de Juquiâ, como fonte de matëria prima fosfätica.

Por outro lado, nas condigöes de intemperismo prevalecentes, jazidas dêsse tipo dificilmente são identifi cadas no campo. Por esses motivos, julgou-se oportuno veri ficar a aplicabilidade dos mëtodos de prospecsão geoquimica na localidade de Juquia. Com êste objetivo, foram colhidas 380 amostras de solos em perfis de prospeceão geoquimica com $8 \mathrm{~km}$ de extensão, cobrindo âreas consideradas represen tativas. o teor de fósforo das amostras colhidas foi deter minado pelos mëtodos comumente utilizados em prospecsão geo quimica.

Subsidiariamente, considerou-se ainda a possi bilidade de delimitar contatos entre diferentes tipos de ro chas, encobertos pelo manto de intemperismo, pela variagão dos teores de fósforo nos solos dexivados dessas rochas. 


\section{1) - Amostragem}

As amostras foram colhidas wo Zongo de perfis radiais ao centro do Morro do serrote, quando localizados nas encostas dêste, alëm de alguns outros atravessando ăreas possivelmente ocupadas por diversos tipos de rochas (sienito e piroxenito, principalmente).

A amostragem foi efetuada em picadas ou cami nhos ja existentes, tomandomse precaugöes para evitar a pos sibilidade de contaminagão por material proveniente de outros locais. o intervalo para a tomada de amostras no Morro do serrote foi de 20 metros, com corregão aproximada pa ra a topografia. Nos outros perfis o intervalo de amostragem foi de 20 ou 40 metros; o primeiro para verificar possi veis variacões numa ärea supostamente ocupada pela mesma ro cha, o segundo para tentar localizar alguns contatos entre rochas alcalinas, fenitos e encaixantes.

A amostragem foi feita por meio de um trado manual, com rosca de $3 / 4$ de polegada, recolhendo-se material da superficie até 90 centimetros de profundidade, exceto a parte superficial rica em material organico. Nos locais on de não se pôde atingix a profundidade mäxima desejada, devi do à presenga de magnetita, silex ou seixos, amostroumse o märimo possivel, procurando recolher a mesma quantidade de material.

\section{2) - Preparagão das amostras}

As amostras foram secas em estufa, por uma ho ra a $1000 \mathrm{Cs}$ e depois moidas em almofariz de porcelanas sem destruir os grãos maiores de magnetita Desta maneira foi desagregada e moída apenas a parte argilosa e os grãos mais finos do solo. Teoricamente, a retirada de grãos grossos não fosfäticos falseia o teor mëdio da amostra. Entretanto, como na grande maioria das amostras a proporsão de fragmentos maiores ë pequena, na prätica êsse procedimento é mais conveniente e não introduz êrros significativos para fins 
de prospecsão geoquimica.

As amostras assim preparadas, peneiradas a "sê co, apresentam atë $35 \%$ de material abaixo de $0.074 \mathrm{~mm}$, haven do porém algumas amostras com maior proporgäo de grãos grossos. A maiox parte do material fica retida acima de $0,105 \mathrm{~mm}$; isto dä a impressão de que a granulagão é irregular e bastante grossa. Uma simples lavagem da fracão maior que $0,105 \mathrm{~mm}$, no entanto, mostra que na realidade se trata princi palmente de paxticulas argilosas agregadas; após lavagem na peneira, apenas com leve friceño, a fracão abaixo de $0.074 \mathrm{~mm}$, em geral, ultrapassa $70 \%$ dos constituintes da amostra. Este fato tamberm foi notado na lavagem de amostras do solo, para estudo dos minerais residuais. Notou-se que a fragão abaixo de $0,074 \mathrm{~mm}$, sem moagem alguma do material, sö $\ddot{e}$ inferior a $50 \%$ em algumas poucas amostras, contendo barita e magnetita bundante. Concluiu-se que, paxa fins de dosagens geoquimicas, não havia necessidade de moagem muito fina das amostras e que mesmo os agregados de maíor granulagäo poderiam ser incluidos em amostras sufioientemente homogêneas e representativas.

3) - Dosagem de fösforo

o mëtodo empregado para a dosagem do fösforo con tido nos solos foi o utitizado peio United States Geological Survey (Ward e outros, 1963), com aigumas modificagöes. o më todo é colorimëtrico e envolve a formacão de um complexo ama relo, pela reagão de uma solugão de vanadato-molibdato com uma solugão contendo fösforo.

A solubilizagäo do fosforo contido nas amostras de solo foi efetuada de duas maneiras diversas; a primeira constou sòmente de ataque äcido a quente e subsequente deter minacão do fösforo solubilizado; trata-se de uma dosagem parcial. No segundo caso, efetuou-se a fusão da amostra com fiu xo (KHSO ${ }_{4}$ ' e posterior ataque äeido; trata-se de solubilizacão total do fosforo.

A utilizacão do mëtodo de prospecsão geoquimica, com dosagem pareial do fósforo contido, visava tentar delimi- 
tar a ärea rica em fosfatos no Morro do serrote, bem como de teatar variagôes no conteüdo de fosforo dos solos, em fincáo do tipo de rocha subjacente. A quantidade de amostra atacam da foi de aproximadamente 0,1 grama. 0 ataque årido joi fei to com $H N O_{3}-4 M$ a quente, aquesendo-se duas vêzes ate a fiervu ras em tubo de ensaio. A solucäo obtida, aposs esfriamento diluigäo atë $10 \mathrm{ml}$ com ägua desizlada ou demineralizadas apre senta-se milito iuxva devido à presenga de argita em suspensĩo, clareando após centrifugagão ou repouso de aproximadamente 6 horas.

Utilizou-se a comparagäo visual ou colorimerzo para medir a intensidade da coloragão amareia obrida para de terominada amostra. A comparagäo fisi feita com padrôses que contêm quantidades conhecidas de fousforo.

Segundo Ward outros (1963), as solugberan-

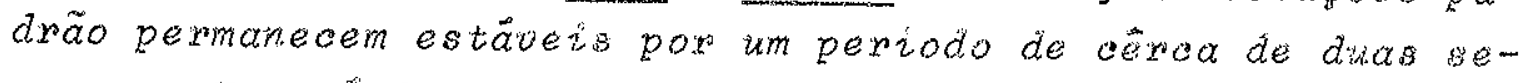
manas. No pratica, verificoumse um empaitiderimento das solu gões em praso muito infexiox. razä pela qual se prejezu pre parar padroes de dois em dois dias " De qualquex mantira, é mais pratico o uso de im coloximetro, aytistado para 430 miti microns de comprimento de onda, para efetuar a medida das in tensidades de coloragão. Apös a elaboxasão de uma curva dé calibracão, os padrões se toxnam desnecessarrios, con excesäo de testes em branoo a intervalos regulares.

os primeiros resultados obtidos por dosagem geoquimica parcial foram confrontados com anaitses quimicas das mesmas amostras, obtendo-se uma correspondéncia nas anomalias, se bem que a dosagem geoquimica apresente maion con traste em relagäo aopackground". Verificoumse que amostras com teor baixo de $P_{2} O_{5}($ ( $1 \%)$ se comportam de maneira seme thante, isto é. a dosagem nâ ê sensivel para baixos teores. Atrave̊s de uma sẻrie de dosagens repetidas, verificou-se tam bëm a reprodutibilidade dos resultados, que se comportam de maneixa satisfatöria, considerando o mëtodo utilizado.

Notesse que os pesultados obridos por simples comparacão visual com uma escala de padxöes, tëonica utiliza da para quase tôdas as anălises sem fusão, variam de um obser 
vador para outro; um outro fator de incerteza deve-se do fa to de cada padrão corresponder ao dobro do teor do anterior. Por exemplos tomando $2 \mathrm{ml}$ da soluça a dosar e obtendo uma co loracão intermediaria entre os padrôes correspondentes a 30 $e 60 \mathrm{Mg} P$, sem interpolagões, as opsões são 1500 ou $3000 \mathrm{ppm}$ de fösforo, respectivamente; com interpolasão, conforme o observador os resultados podem ser 1750,2000 ou 2250 ppm,po dendo-se incorrer em êrro considerävel. por êste motivo, em anălises repetidas ocorrem variagöes importantes.

Nas anälises efetuadas apös fusão prëvia, na presenca de sulfato åcido de södio ou potässio, e posterior ataque acido, solubilizou-se prăticamente todo o fosforo con tido na amosira inclusive na magnetita. Neste procedimento, a intensidede da coloracão do complexo foi estimada a partix da medida da absorbâncias com colorimetro ajustado em $430 \mathrm{m \mu}$ de comprimento de onda. As leituras foram comparadas a uma curva de calibragäo, feita a paritr de padröes conhecidos, ob tendo-se os valôxes em ppm de $P$.

Uma das possiveis fontes de êxro do mëtodo uti lizado ë a fatta de estabilidade da coloragáda das solugöes. que normatimente se torna mais intensa no decorrer do tempo. até atingix um maximo, empalidesendo em seguida. para eliminar a influência dêsse fator, as leituras passaram a sex efetuadas 30 minutos apös a oblengäo do complexo. A variagäo de coloracaro foi pequena entre 30 minutos e 2 horas aposs for macäo do complexo, podendowse efetuax as leituras sem grandes discrepancias. A ceprodutibitidade dos resultados obtidos tamberm foi verificada neste caso, revelando-se satisfatöria para as finalidades previstas.

A Tabela 2 apresenta o resultado de diversas dosagens, rom e sem fusăo, bem como a comparacấo com resultados de anatises quimiads. Os resultados obtidos em dosagens sucessivas consiam da labela iz, para demonstrar a reprodutibi Zidade do método.

Os resultados obtidos com fusäo säo bastante próximos dos fornecidos por anälise quimica convenoional atë 
Amostra

$x$

s

3

4

5

6

$?$

8

9

20

41

12

13

14

15
Dosagem geoquimica

pareial total

$$
140
$$

725

100

70

100

1.900

1.900

2.200

2.200

2.300

330

5.500

4.950

1.800

288.000
6.000

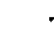

5.800

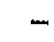

5.300
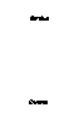

9.600

22.600

12.400

36.600

68.000

78.000

102.500

720.000
Anälise quimica

4.400

4.800

5.700

5.300

6.200

7.900

8.600

8.600

9.000

9.400

49.800

35.000

47.200

61.000

$33 \% .000$

Tabela z: Comparagâo entre nesultados obtidospor do sagem geoquimica anälise quimica, em so los do Morro do serrotes em ppm de fösforo. 
Amostra

3

5

10

8

2.000

2.000

2.500

2.000

1.830

2.500

2.400

2.000

2.500

500

11

300

200

2.500

14

1.500

1.500

250.000

15
Dosagem Geoquimica ( $p p m P$ )

Parcial

(mëdia)

Total

(mëdia)

140

6.100

5.900

6.000

5.600

5.900

5.800

100

5.200

5.400

5.300

60

2.200

9.200

$10.000 \quad 9.600$

12.700

$.13 .100 \quad 12.600$

10.350

$12.500 \quad 11.400$

46.000

31.250

36.600

32.500

107.000

$98.000 \quad 102.500$

98.000

78.000

$98.000 \quad 120.000$

185.000

Tabela 13: Repetifäo de dosagens geoquimicas para contrôle da reprodutibilidade dos re sultados。 
cêrca de $10.000 \mathrm{ppm} P$. Acima dêsse valor a dosagem geoquimi ca passa a indicar teores muito mais elevados, aproximando-se do dôbro da anälise quimica.

A dosagem sem fusäo apenas indica valôres anô malos em amostras contendo quantidades bastante elevadas de fösforo; präticamente não se notam anomalias abaixo de 5000 ppm de $P$ contido, mas em amostyos mais picas o contraste se torna evidente. Como uma das finalidades da aplicacão do método, sem fusão prëvia, era localizar minërio superficial em locais desconhecidos, a precisão seria suficiente, inclu sive para detectar minério fosfatico pobre, com apenas poucos porcento de $P_{2} \mathrm{O}_{5}$. Eete mêtodo tambëm não indica o fós foro contido em outros minerais, por exemplo magnetita, ou em formas pouco solüveis, como monazita. Esta pode ser uma das razões pelas quais algumas amostras, como as de no 11 e 14, apresentam resultados consistentemente baixos, quando a nalisadas por dosagem paroial. Na amostra 14, no entanto, $\ddot{e}$ dificil supor que $6,1 \%$ de $P$ estejam contidos em minerais pouco solüveis. Nota-se, tambëm, o valox excessivamente al to encontrado na amostra no. 15, na dosagem sem fusäo, atin gindo o dôbro do valor real em très anallises sucessivas; 0 motivo dêste comportamento è desconhecido, mas talvez seja devido à interfexência de algum outro elemento.

A Figura 13 apresenta os mesmos dados da tabe Ia 12 sob forma de gräfico, para methor visualizacão dos va lôres absolutos obtidos por cada um dos mëtodos de dosagem geoquimica.

\section{4) - Resultados \\ a) - Dosagem parcial do fösforo.}

A anälise de 380 amostras indicou anomalias $\underline{a}$ preciäveis apenas em certa porcão do Morro do serrote, na área do carbonatito interno (Figura 14). Excluindo a parte superior da elevasão, as amostras apresentaram teores muito semelhantes, em geral inferiores a $200 \mathrm{ppm}$ de fösforo; alguns 


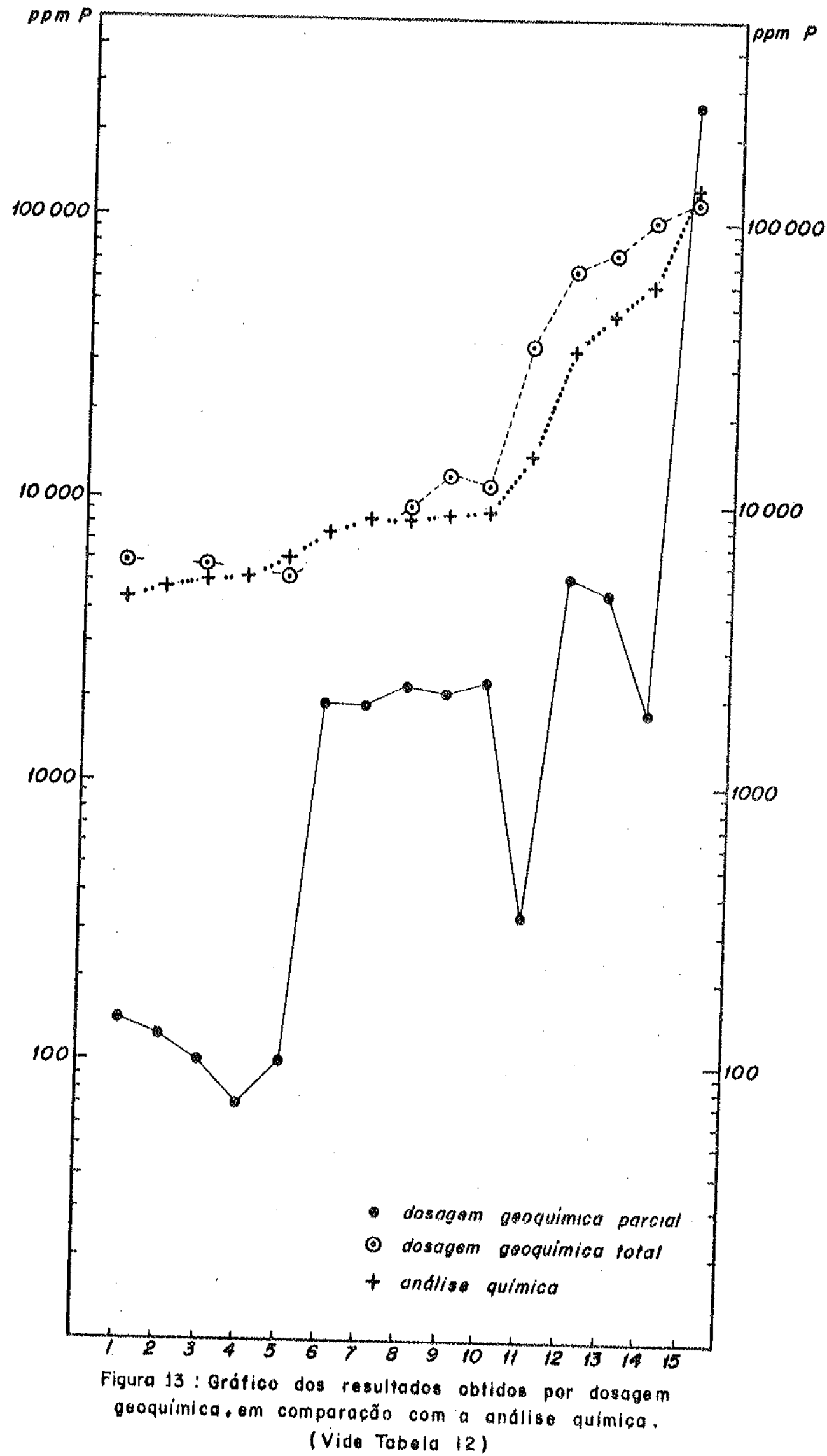




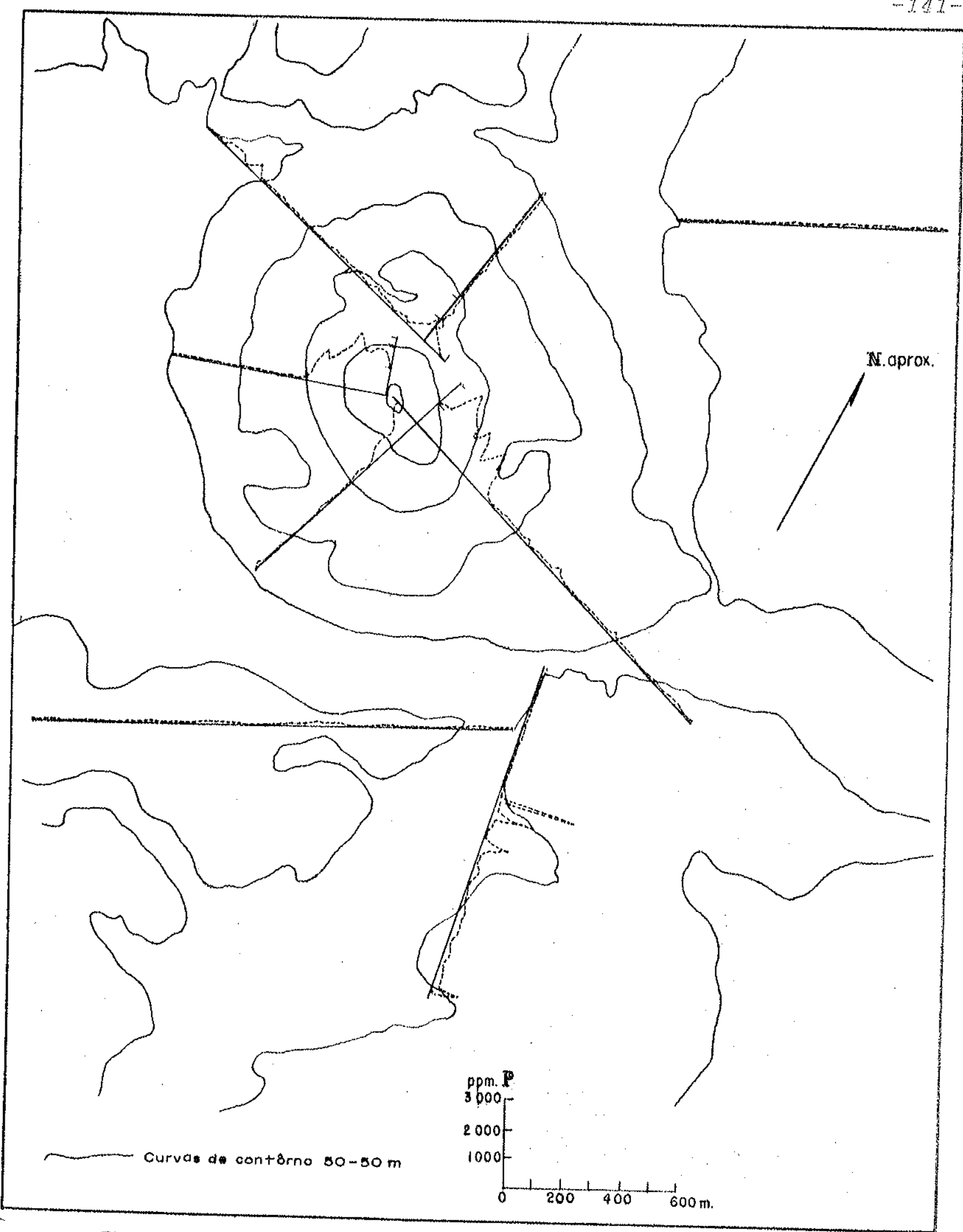

Fig. 14: Perfis de prospecçöo geoquímica no Morro do Serrote rochos alcalinas vizinhas. 
teores erräticos mais altos form ensontrados em amostras iso ladas. O conjunto de amostras da parte supexior do morro,pro veritentes de varios perfis radiais, indisam anomatias cujo

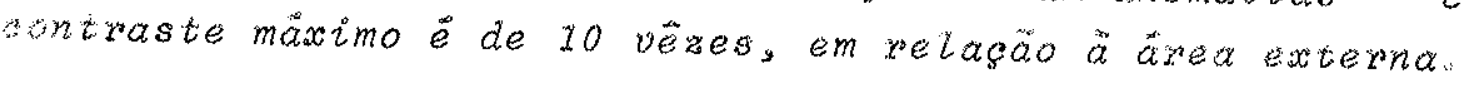

Este comportamento mostra que apenas na parte coxtespondente ao carbonatito interno, sem respetray seus iz mites exatos, ocorrem solos contendo maior proporgä de fosfa fos relativamente soluveis, pröximos a superfiate. Tambëm näo foram xeconheoidas arreas com levres elevados de $p_{2} o_{5}$, pröximo a superficie, nas rochas aloathas eirounvizinhas. Alèm diss. wewificou-se que náo é possivei delimitar os diversos ti pos de rochas alcalinas presentes no complexo, en funcao do

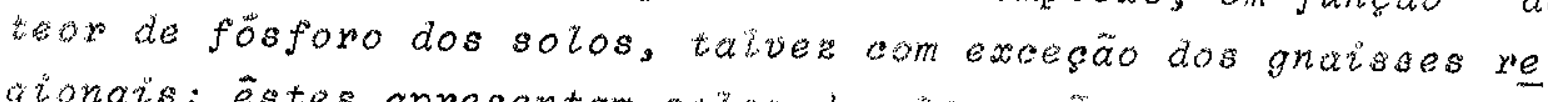

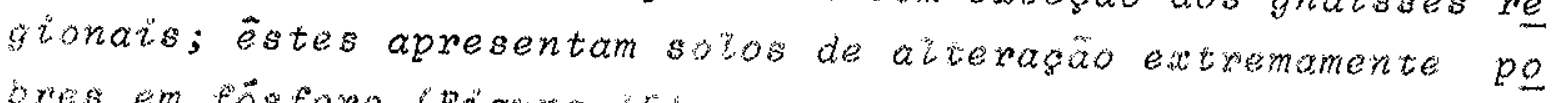

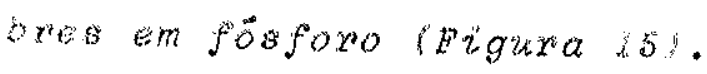

\section{b) Dosagem total do fos foro.}

Os resultados das dosagens efeculdas oom fuscäo

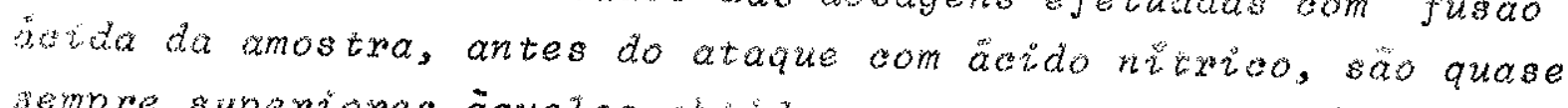

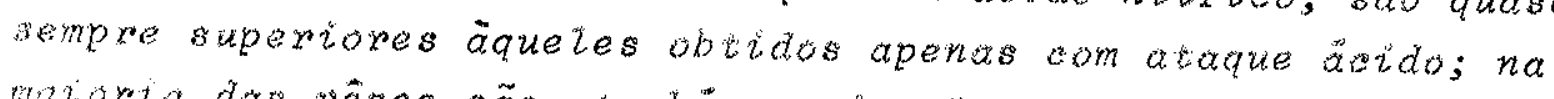
malorta das vezes são, tambëm, mais alsos do que o resultado

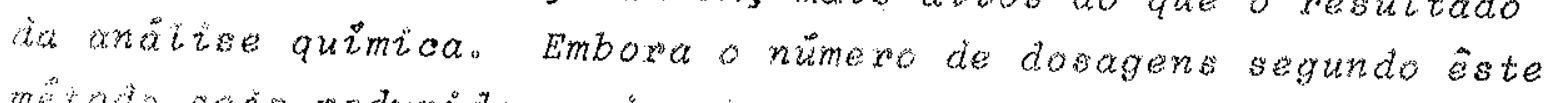

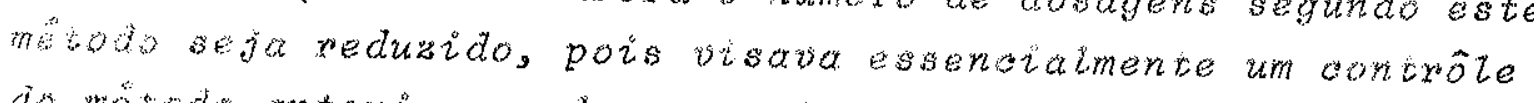
do mbodo anterior, pode-se vexticar que ele tambëm näo permïre distinguir a ärea ocupada pezas diferentes rochas alca linas, a näo ser o carbonatito. Tanto a area do darbonarito interno como do externo podem sex distinguidas, pois apresentam teores mais elevados de fosforo, oonforme se nota na pigu

\section{b. - conelusoes.}

A aplicagão expeximenta da prospecgäo geoquimi ca paxa fosforo, em solos da ärea do complexo alaalino de Ju-

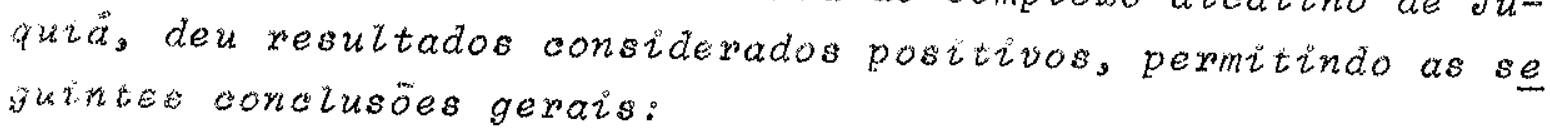




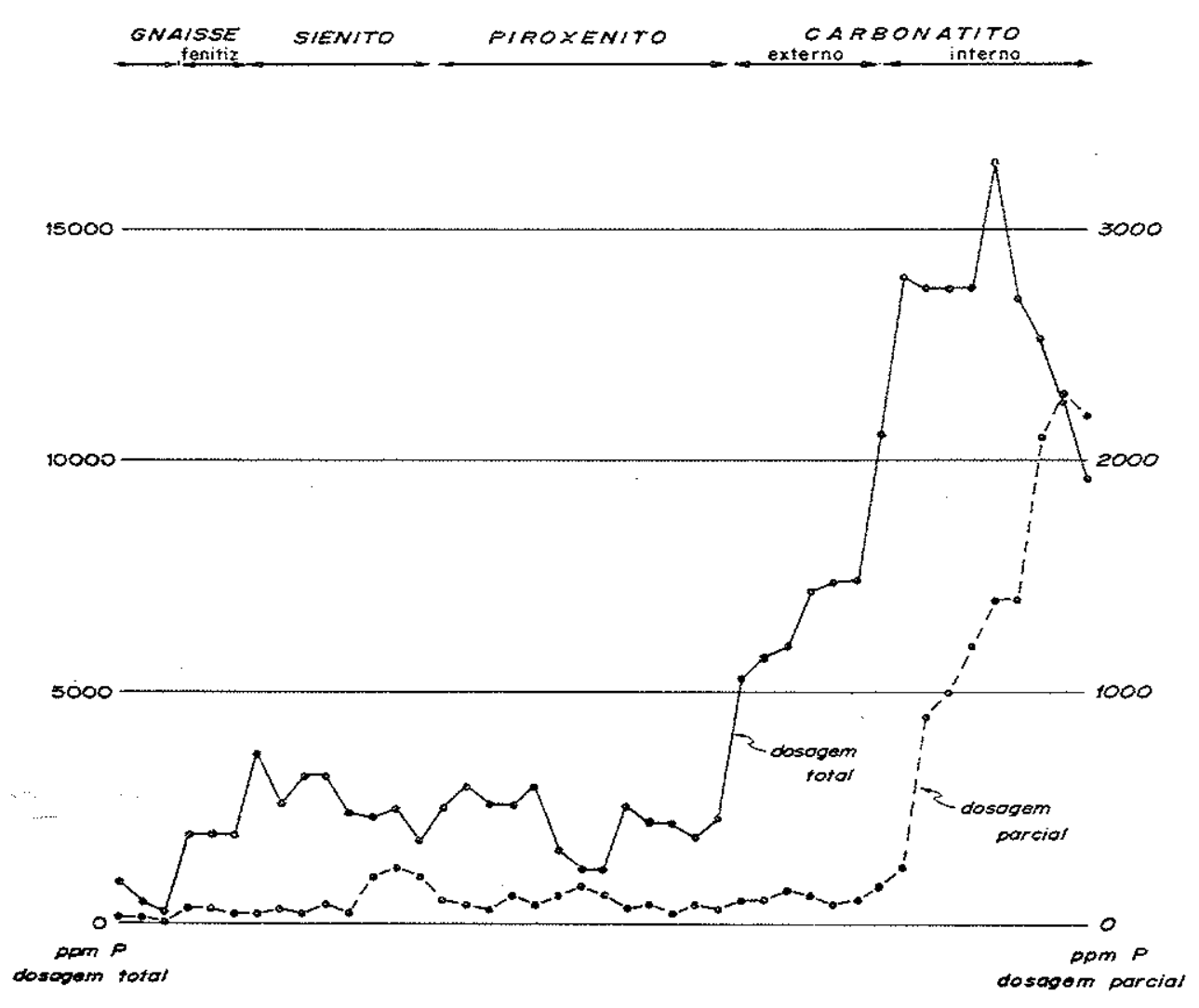

Fig. 15: Resultodos de dosagem geoquímica total e porcial, em solos oriundos de diversas rochos do intrusāo alcalino de Juquió. 
a - o processo ë aplicävel para a localizacão de teores anô malos de fósforo em solos, tanto com solubilizagão to tal como parcial dos fosfatos.

$b$ - Com solubilizacão total do fósforo contido, por meio de fusão ácida, pode-se localizar äreas com anomalias de pequeno contraste; as dosagens têm precisão semi-quanti tativa.

- A solubilizacão parcial do fósforo, obtida apenas por ataque äcido, sö permite delimitar areas com mais de $3-4 \% P_{2}{ }_{5}$, de preferência na forma de fosfatos fàcilmen te solüveis; os resultados näo devem ser considerados semi-quantitativos, mas apenas como qualitativos; a não ser em casos especiais, o método indica uma parcela re duzida do fösforo contido na amostra, em geral inferior a 20\% do total; entretanto, qualquer concentracão de in terêsse econômico seria localizada por êsse processo.

d- os solos resultantes da decomposigão de gnaisses encaixantes podem ser distinguidos por dosagem geoquimica, pois apresentam teores em foosforo muito mais baixos do que a área ocupada pelo complexo alcalino. Jä os gnais ses fenitizados säo mais ricos em fosforo, com conteúdos semethantes às rochas alcalinas.

e - Os solos que capeiam os carbonatitos possuem teores va riäveis de fösforo, em geral bem mais altos do que as rochas alcalinas; na ärea correspondente ao carbonatito externo contêm aproximadamente o döbro e na parte corres pondente ao corpo interno podem apresentar contrastes de 5 a 10 vêzes, segundo determinagöes feitas por dosagem geoquimica total.

$f$ - A jazida de fosfato do Morro do serrote não pode ser zo calizada, ou aproximadamente delimitada, por prospeceão geoquimica superficial, pois encontra-se recoberta por camada bastante espesssa $(2-8 \mathrm{~m})$ de solos pobres em fösfo ro.

g - O material aluvial, dos brejos que circundam o Morro do Serrote, não apresenta enriquecimento em fosfatos na sua parte superficial, nas amostras analisadas. 


\section{VII - RECURSOS MINERAIS}

Atualmente $\vec{e}$ conhecida uma grande variedade de minerais de interêsse econômico associada a rochas alcalinas e carbonatitos. Deans (1966) apresenta um resumo das princi pais jazidas conhecidas no mundo, relacionadas a êsses tipos de rochas, bem como suas caracteristicas mais notaveis. Melcher (1966b) tambëm relaciona as mais importantes jazidas que podem sex localizadas nessas associacões.

Os principais elementos e matërias primas encon trados nesse tipo de localidades, cêrca de 15 , säo os seguin tes: $\mathrm{Fe}, \mathrm{Ni}, \mathrm{Nb}$ (Ta), V, Terras Raras, $\mathrm{Zr}, \mathrm{P}, \mathrm{Sr}, \mathrm{Ba}, \mathrm{Cu}$, $\mathrm{CaCO}_{3}$, Vermiculita, Argilas, Fluorita, alêm das possibilidades relativas a $U$, Th e Mo. A natureza e importancia de cada uma dessas matërias primas minerais depende do tipo de ro chas alcatinas $e$ de carbonatito, de sua extensão, das relasôes de campo entre as diversas variedades e, como fator muito importante, da evolucão fisiogxäfica de cada ocorrência. Evi dentemente, em cada caso incidem ainda muitos processos mine ratogenëticos, cuja natureza exata, em parte, ainda ë desconhecida.

Escapa aos objetivos dêste trabalho fazer um resumo ou analise completa de todos os recuxsos minerais asso ciados a complexos alcalinos em geral. Entretanto, a ocorrên cia de Juquiä apresenta uma sëxie de semelhangas flagrantes com outras localidades congêneres, onde existem depösitos minerais importantes. Alëm disso, em Juquiä jä foram encontrados diversos minerais de possivel interesse economico, quais sejam: fosfatos, baxita, magnetita, pirocloro, monazita, mine rais de estróncio e terras raras, devendo considerar-se, ainda, a presensa da massa carbonätica em si, como recurso mineral em potencial. Por êsses motivos, justifica-se descrever cada um dêsses minerais e examinax as suas possibilidades econômicas.

A primeira noticia sôbre uma ocorrência mineral de possivel interêsse econômico, em Juquiă, se refere à descoberta de barita, ocorrida em 1927 e reportada por Leonardos (1934). Nos Zevantamentos dos recursos minerais do Estado de 
São pauzo, Knecht (1934 e 1940) tambëm menciona a ocorrência de barita em Juquia. Em 1939, Knecht e Felicissimo Jx. publi caram trabatho sôbre a possibilidade de aproveitamento econô mico da magnetita do Morro do serrote, que, no entanto, nunca chegou a ser explotada. As primeiras referências sôbre fosfa tos na área do complexo alcalino de Juquiä são de Knecht (1948) e Guimarães e Feircissimo Jn. 11950). Nas äreas denominadas Guavixuva e Cägado, Maciel (1952) admitiu grandes re servas de fosfatos no contato de sienitos com pixoxenito, que, infelizmente, não foram confirmadas.

A ünica matëria proima mineral que atë hoje foi alvo de alguma pesquisa e lavra em escala modesta são os fosfatos do Morro do serrote. Nenhum dos outros tipos de possiveis minérios foi objeto de um eswudo realmente conclusivo.

Esses fosfatos constituem a üica reserva compro vada de interêsse econômico da ărea, estando concentrados no flanco sul do Morro do serrotes próximo à sua base. Nesse lo cal encontra-se um corte irregular a cëu aberto, trabalhado de maneira primitiva e intermitente: apresenta cêrca de 40 metros de altura mäxima e 300 metros de extensão totat. Em sua maior parte o minërio é constituido por carbonato apatita, principal mente na forma de dahtita.? Parte do material apresenta habito criptocristalino, recebendo a designacão genérica de colofana. Felicissimo Jr. (1968) cita ainda a presenca de staffelita e francolita, pelo fato de tex sido revelado certo teor de fluor, por anälise quimica.

De uma maneira geral, os fosfatos se apresentam de duas maneiras distintas. Paxte do material é compacto e cimentado, com aspecto macigo; o restante constitui um agrega do muito poroso, no qual existem finas lamelas interiligadas $e$ muito irregulares, formando um grande numero de cavidades,pre enchidas por material escuro e pulverulento. Nos dois tipos de fosfato podem ocorrer cavidades irregutares, em cujas pare des se depositaram crostas de fosfato com granulasão muito fi na, formando estruturas coloformes ou crescimentos semethan-.. tes a pequenas estalactites; em outros casos, as paredes estäo 
recobertas por cristais bem desenvolvidos. A coloracão dos fosfatos é muito variăvel, desde branco ou amarelado ate marrom escuro, devido à presenca de öxidos de ferro. Os cristais limpidos que revestem algumas cavidades, muitas vê zes sâo incolores e transparentes.

Localmente, se encontram manchas argilosas avermethadas nos fosfatos; ao que parece, constituem blocos alterados de um outro tipo de material, possiveis xenölitos fFoto $3, p .73$, do carbonatito conservados na massa de fos

bandamento ou qualque fosfatos de aspecto poroso não apresentam tuintes; jä o material tipo de orientagão dos seus consti ticas de reprecipitasão, compacto apresenta nitidas caracteris inclinado, em diresão com um bandamento vertical ou muito feicão ainda apresenta centro do morro. Im detathe, essa com aspecto de dobras (Fotos 6 a 9 ).

Algumas amostras apresentam, no meio dos fosfa tos cimentados, cavidades romboédricas preenchidas por mate rial fosfätico escuro e pulverulento. A sua forma sugere que se tratava de cristais de carbonatos, calcita ou dolomi ta, que foram lixiviados, conservando-se o molde (Foto 10). Como jä foi mencionado, o minërio $\vec{e}$ cortado pox veios de barita, semethantes aos encontrados tambëm no carbonatito. No interior dêsses veios, às vêzes, ocorrem ca vidades cujas paredes estão revestidas por cristais bem de senvolvidos de barita. o modo de ocorrência dos veios demons tra serem posteriores à formacão dos fosfatos. A quantidade de barita no minërio ë muito variävel, sendo abundante em alguns locais e rara em outros. os fosfatos conterm, ainda. quantidades variäveis de magnetitas ela ocorre em grãos isola dos e finos no material terroso ou englobada por material se cundärio com granulasão fina a milimëtrica, podendo apresentar formas idiomörficas. outro mineral quase sempre presente no material fosfätico $\ddot{e}$ mica semi-alterada, que se expande quando aquecida, tratando-se de uma variedade de vermiculita; ela em geral é de granulagäo fina, mas ocasionalmente forma placas. 
$-148-$

Fotos 6 e 7 : Aspectos do minério fosfätico poroso. 
Fotos 8 e 9 : Feigós devi das a reprecipitagäo de fos fatos, dando oxigem a cama das macigas e finas de minë rio, intercaladas com mate rial pulverulento e terroso.

Foto 10: Amostra de fosfa to com cavidades romboeddri cass preenchidas por mate rial pulverulento $(x 0,7)$. 
arongadas de $5 \mathrm{~cm}$ ou mais de comprimento.

A ocorrencia de grande quantidade de fosfatos reprecipitados indica que a area esteve exposta durante Iongo periodo, a intensos processos intemperricos, que cau saram dissolusão dos fosfatos e subsequente reprecipitagão, em condigões favorâveis e a maior profundidade. Êstes fenô menos devem estar relacionados a evolusão fisiogräfica da região, tambëm responsävel pelos niveis de terragos existen tes.

Do ponto de vista da composigâo e textura, os fosfatos do Morro do Serrote diferem dos existentes em Jacu piranga, no Morro da Mina. Nesse local, os fosfatos que ca peavam o carbonatito exam de origem essencialmente residual. apresentando alguma cimentagäo; seu principal constituinte era apatita microcristalina e cristalina, podendo as dimen söes dos individuos ultrapassar $1 \mathrm{~cm}$. Estas diferencas in dicam tambëm uma ąão mais prolongada e intensa dos processos intempëricos em Juquiä.

Quanto à sua oxigem. os fosfatos do Morro do Serrote não podem ser definitivamente classificados. Em pri meiro zugar deve-se considerar que o carbonatito interno apresenta teores muito baixos de $\mathrm{P}_{2} \mathrm{O}_{5}$ devendo ter sido redu zida, ou mesmo inexistente, a sua contribuigâo na formacão de mine̊rio secundarrio. Jä o carbonatito extexno, comprovado apenas na årea subjacente ao depösito, apresenta apatita e dahlita subordinada: êle pode ser responsâvel pela formacão da jazida, a partir de processos intempëricos, acumulacão re sidual e talvez eluvial dos fosfatos, combinados com solubi lizacão e reprecipitąão dos mesmos. No entanto, deve-se con siderar a posicão do corpo de minêrio, na base do morro com carbonatito, proxximo ao contato con rochas piroxeniticas ou i joliticas. A ocorrência de piroxenitos nessa ärea e̊ apenas su posta,por causa da existência de uma baixada e de rochas dês te tipo na base norte do morro. Ijolitos,por sua vez,ocupam uma ärea restrita,pouco a leste da jazida. A posigäo do corpo de minërio leva a considerar a possibilidade da existência de uma zona marginal de carbonatito enriquecido em apatita, ou en tão de piroxenito ou ijotito com muita apatita.zonas com rochas 
ricas em fosfatos são conhecidas em diversas ocorrências con gêneres. Como exemplo, pode-se citar piroxenito com apatita em Palabora e Dorowa ou carbonatito enriquecido em apatita em Tundulu.

Sem düvida, os processos intempëricos foram im portantes da formagão do depösito, ocorrendo posterior repre cipitąão e enriquecimento; em conseqllência, hä locais em que - minërio contëm atë $30 \%$ de $\mathrm{P}_{2} \mathrm{O}_{5}$.

A rocha carbonatitica do Morro do serrote encon tra-se capeada por uma camada de solo, que geralmente atinge uma espessura superior a 20 metros, com excecão da parte su perior do morro, onde a rocha aflora em alguns locais. As poucas sondagens efetuadas atingiram rocha fresca, intercala da com algumas zonas de alteracäo, sempre a mais de 25 me tros de profundidade. Na maioria das vêzes, o solo apresenta teores baixos em fösforo, menores que $5 \% P_{2}{ }_{5}$, podendo ser considerado esterrit atế profundidades que, conforme o local, variam de 5 ate mais de 15 metros, inclusive sobre o minerrio fosfätico. Na ärea correspondente à jazida, abaixo dêste ca peamento estëriz, em geral se encontra uma certa espessura de minerrio pobre, cujo teor varia entre 5 e $10 \%$ de ${ }_{P_{2}}{ }^{O} 5^{\circ}$ Dentro dessa massa com teores intermediarios, ou abaixo dela, locali za-se o minério com teor superior a $10 \%$ de pentöxido de fösforo. A espessura da camada rica varia de 1 atë mais de 10 metros, comportando-se de maneira irregular. Uma galeria ho rizontal aberta no minërio atravessou mais de 30 metros de material com teor superior a 15\%, sem atingir rocha fresca ou minério pobre.

A jazida de fosfato do Morro do serrote, incluin do o minërio pobre, pelos dados disponiveis restringe-se aos flancos sul e sudoeste da elevacão, de sua meia altura para baixo. O minério rico é mais frequente proximo à ärea atualmente em explotacão, mas foi encontrado com espessuras restri tas em alguns outros pontos.

Aiguns posos abextos na parte norte e leste do morro encontraxam minërio pobre, sem indicagão de continuidade. Deve ser observado que, mesmo considerando as concentra- 
Sões fosfäticas como residuo insolüvel de carbonatitos, não é possivel correlacionar diretamente a ocorrência de fosfatos com a distribuigão dos carbonatitos. Isto porque podem ocorrer carbonatitos pobres em fosfato, ou não haver condicões favoräveis para a acumulasão residual.

Os dados disponiveis sôbre as reservas economicas de material fosfätico do Morro do serrote se referem apenas à parte sul, onde existe uma reserva indicada em tôx no de 2 milhões de toneladas com teor acima de $15 \% \mathrm{P}_{2} \mathrm{O}_{5}$, mais cêrca de 1 mithão de toneladas acima de $10 \% \mathrm{P}_{2}{ }^{0} 5^{\circ}$ A Lavra dêste material exige a retixada do capeamento de solos com teores abaixo de $5 \%$ de ${ }_{2}{ }_{2}{ }_{5}$, bem como do minerrio pobre $\left(5-10 \% \mathrm{P}_{2} \mathrm{O}_{5}\right)$, cuja espessura $\vec{e}$ apreciável.

Não hä indicagão sôbre a profundidade mäxima dos fosfatos de alto teor, pois a reouperacão nas sondagens foi muito baixa; mesmo assim, seu aproveitamento esta limitado $\tilde{a}$ base do Morro do serrote, onde se formaram brejos, muito pröximos do nivel de base da região. os aluviões pre sentes em frente $\ddot{a}$ jazida foram examinados para verificar a possibilidade de existência de fosfatos, obtendo-se resulta dos negativos.

Maciel (1952) se refere à ocorrência de jazi das de apatita na ärea do Guaviruva e Cägado, ao sul do Mor ro do Sexrote; localiza-as no contato de sienitos e piroxenitos, com forma de ferradura e cêrca de 50 metros de espes sura mäxima. Algumas dezenas de furos de trado executados posteriormente no local, no entanto, apenas indicaram algumas concentragöes muito restritas de apatita; a maioria das amos tras apresenta teores muito baixos de $\mathrm{P}_{2} \mathrm{O}_{5}$, abaixo de $3 \%$.

Em local pröximo, tambëm na ärea indicada por Maciel (1952), foi encontrado um afloramento do material des crito como minério. Trata-se de una concentragão de apatita, com hăbito ovoiide ou pxismätico, contendo certa quantidade de magnetita, cimentada por fosfatos secundärios ou limonita. o tipo de material sugere que se trata de concentracoes muito restritas de apatita residual, provenientes da decomposicão de sienitos; em condicões propicias a apatita pode se acumu- 
Lar, sendo posteriormente cimentada. A extensão lateral e vertical da ocorrência, considerando a oxigem acima, deve ser muito limitada. Além disso, a situagão topogräfica do local, muito pröximo ao nivel de base, $\vec{e}$ desfavorävel.

outra matëria prima mineral, muitas vêzes

as sociada a carbonatitos, $\dot{e}$ o pirocloro. Nos solos que recobrem o Morro do serrote encontra-se êsse mineral, em parte semi-alterado, proveniente de carbonatito dissolvido. Na prö pria rocha carbonatica foram identificados grãos comumente idiomörficos de piroctoro. Tambëm em uma sondagem foi encon trada uma zona mais rica nesse mineral; a anälise quimica de uma amostra de testemunho revelou $0,09 \% \mathrm{Nb}_{2} \mathrm{O}_{5}$. Nos solos re siduais o mineral tamberm foi identificado, possuindo granula são variävel, às vêzes milimëtrica. Para obter uma primeirá idëia dos teores dos solos, foram analisadas quatro amostras compostas provenientes de posos e furos de trado. Uma amos tra do flanco norte do morro apresentou resultado negativo. outra, correspondente do solo de alteracão do carbonatito in terno, de um poso situado cêrca de 20 metros abaixo do cume do Morro do Serrote, indicou um teor de $0,12 \% \mathrm{Nb}_{2} \mathrm{O}_{5}$, em mate rial representativo atë $13 \mathrm{~m}$ de profundidade. As duas outras amostras provêm da ärea ocupada pelo carbonatito externo; uma delas, colhida pröximo à jazida de fosfato, apresenta $0,28 \% \mathrm{Nb}_{2} \mathrm{O}_{5}$. no material colhido entre 0 e $18 \mathrm{~m}$ de profundida de; a outra, proveniente do flanco oeste, com material repre sentativo até $21 \mathrm{~m}$ de profundidade, indicou $0,4 \% \mathrm{Nb}{ }_{2} \mathrm{O}_{5}$. Nesta ültima amostra pode haver certa influencia do carbonatito in terno, pois o poso localiza-se próximo ao contato de dois cpr pos.

A existência de minerais de niöbio poderä, even tualmente, tornar-se de interêsse econômico. Na hipötese do aproveitamento conjunto dos fosfatos e do niöbio, podexä tornax-se economicamente exeqüivel lavrar material com baixo teor de ${ }_{2} \mathrm{O}_{5}$.

Outra possibilidade, embora ainda muito remota, seria a recuperagão concomitante dos minerais de $B a$, $S x$, ou mesmo dos elementos de terras raras. Neste grupo identificoum 
-se cerrio, presente na monazita e ancylita do carbonatito, ian tânio e muito pouco itrio.

A distribuicão semi-quantitativa dêsses elementos foi obtida pela análise, por fluorescência de raios-X, de algumas amostras de caxbonatito e de solos, provenientes de diversas partes do Morro do serrote, excluindo a parte norte (Tabela 14). Deve-se observar, entretanto, que os teores indi cados dêsses elementos têm apenas caräcter qualitativo ou semi-quantitativo. Sua determinasão foi feita por comparasão com amostras analisadas por outros mëtodos, porém não se dispunha de padrões exatos e não foram considerados possiveis $e$ feitos de matriz ou outras interferências inerentes ao mëtodo.

Analisando, por exemplo, os resultados referentes à amostra 2, nota-se que êles não representam a mëdia de $2 a, 2 b$ e 2c, conforme seria de esperar em uma amostra compos ta. Este comportamento pode ser devido à granuzagão irreguzar e falta de homogeneidade da amostra, mas o efeito de matriz de ve tambëm ter certa influência. Amostras de locais diferentes podem apresentar grandes diferencas de matriz, o que torna imprecisa uma comparacão direta do numero de contagens obtidas. Isto pode sex exemplificado peta discrepância no nümero de con tagens obtidas para Ce e La nas amostras $A$ e $B$, provenientes de outra localidade, que possuem teores iguais, conforme anăli se espectroquimica.

Verifica-se que a maioria das amostras, com exce \&ão daquelas com mais de $15 \% \mathrm{P}_{2} \mathrm{O}_{5}$, apresenta distribuigão mais ou menos constante dos diversos elementos. As contagens indi cam conteüdo alto de Ce e la e baixos valöres de $Y$, tanto na rocha carbonatitica, como nos solos. De um modo geral, verifi cou-se que o carbonatito $e$ os solos apresentam conteüdo em $C e$ da ordem de 0,1 a $1 \%$; värias amostras de solo aproximam-se de $1 \%$, podendo inclusive ultrapassar êste valor. o La, por sua vez, predomina em quantidades entre 0,1 e $0,5 \%$, mas valores in feriores a $0,1 \%$ não são raros. o Y indica valôres mais baixos, de 0,1 a 0,01\%, aproximando-se mais dêste ültimo, sendo por vêzes ainda menor. Uma üica amostra apresentou nümero de con tagens elevado, equivalente a $0,1-1 \%$ de $y$. 


\begin{tabular}{|c|c|c|c|c|c|c|}
\hline \multirow{2}{*}{\multicolumn{2}{|c|}{ AMOSTRA }} & \multicolumn{4}{|c|}{$\begin{array}{l}\text { Pluoresconcic de rabos } X \\
\text { Número de contagens }\end{array}$} & \multirow[t]{2}{*}{$\% P_{2} \mathrm{O}_{3}$} \\
\hline & & $\mathrm{Ce}$ & $\mathrm{Lo}$ & $Y$ & $\mathrm{Nb}_{2} \mathrm{O}_{5}$ & \\
\hline 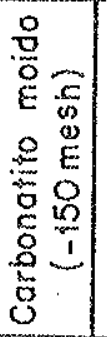 & $\begin{array}{l}c_{1} \\
c_{2} \\
c_{3} \\
c_{4} \\
c_{5}\end{array}$ & $\begin{array}{l}2900 \\
3700 \\
1500 \\
3200 \\
2100\end{array}$ & $\begin{array}{r}1800 \\
2300 \\
500 \\
4600 \\
2000\end{array}$ & $\begin{array}{r}200 \\
1000 \\
100\end{array}$ & & \\
\hline \multirow{7}{*}{ 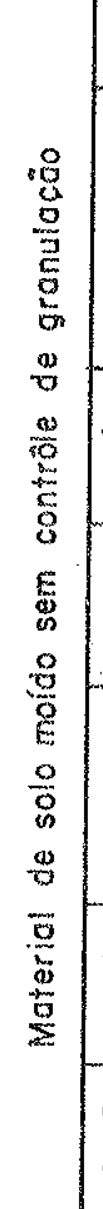 } & i im. & 8100 & 6000 & 2200 & & 6,3 \\
\hline & $\begin{array}{l}\text { 2. }(1-2(m) \\
2 a(1-5 m) \\
2 b(5-15 m) \\
2 c(15-2(m)\end{array}$ & $\begin{array}{l}2300 \\
7000 \\
2700 \\
2000\end{array}$ & $\begin{array}{r}1300 \\
5800 \\
1800 \\
800\end{array}$ & $\begin{array}{l}4400 \\
1700 \\
2700 \\
1900\end{array}$ & $\begin{array}{l}9000(0.4 \%) \\
7900 \\
1000 \\
1000\end{array}$ & $\begin{array}{l}8 \\
3,7 \\
7,2 \\
12,5\end{array}$ \\
\hline & $\begin{array}{l}3 a(0-9 m) \\
3 b(9-15 m)\end{array}$ & $\begin{array}{l}4100 \\
2400\end{array}$ & $\begin{array}{l}2700 \\
1200\end{array}$ & $\begin{array}{ll}2 & 100 \\
3 & 600\end{array}$ & $\begin{array}{l}7600 \\
15800\end{array}$ & $\begin{array}{l}1,9 \\
8,5\end{array}$ \\
\hline & $\begin{array}{l}4 a(1-10 m) \\
4 b(10-20 m)\end{array}$ & $\begin{array}{r}1100 \\
600\end{array}$ & $\begin{array}{l}500 \\
200\end{array}$ & $\begin{array}{l}500 \\
400\end{array}$ & $\begin{array}{r}2300 \\
800\end{array}$ & $\begin{array}{l}2,8 \\
3,4\end{array}$ \\
\hline & $\begin{array}{l}5 a(0-9 m) \\
5 b(9-12 m) \\
5 c(12-18 m)\end{array}$ & $\begin{array}{l}5600 \\
7000 \\
6200\end{array}$ & $\begin{array}{l}3700 \\
4900 \\
4400\end{array}$ & $\begin{array}{l}1000 \\
2000 \\
2100\end{array}$ & $\begin{array}{l}6000 \\
8000 \\
10200\end{array}$ & 2,4 \\
\hline & $\begin{array}{l}6 a(0-8 m) \\
6 b(10-17 m)\end{array}$ & $\begin{array}{l}5900 \\
5300\end{array}$ & $\begin{array}{l}4500 \\
3600\end{array}$ & $\begin{array}{r}000 \\
3500\end{array}$ & $\begin{array}{l}3100 \\
8800\end{array}$ & $\begin{array}{l}3 \\
5\end{array}$ \\
\hline & $\begin{array}{l}G_{1}(21-22 m) \\
G_{2}(28-29 m)\end{array}$ & $\begin{array}{r}1200 \\
400\end{array}$ & $\begin{array}{l}300 \\
200\end{array}$ & 500 & 500 & 20 \\
\hline & $\begin{array}{l}A \\
B\end{array}$ & $\begin{array}{r}11200(1.68) \\
9100(1.68)\end{array}$ & $\begin{array}{l}6200(0,7 \%) \\
4300(0.7 \%)\end{array}$ & $\begin{array}{l}460060946) \\
40000026\end{array}$ & & \\
\hline
\end{tabular}

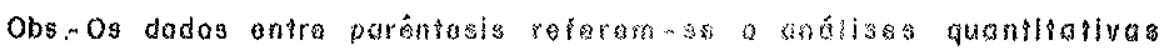
aforuados nat masmea amosmos.

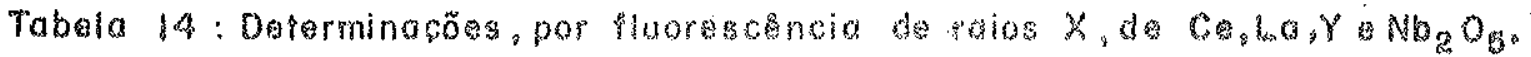

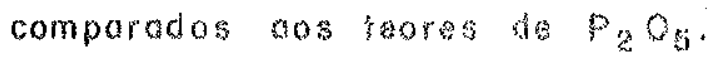


Nas mesmas amostras efetuou-se a medida das con tagens para $\mathrm{Nb}_{2} \mathrm{O}_{5}$, verificando-se, por comparacão com solos analisados por via ümida, que a maioria delas contëm entre 0,1 e 1\% de pentöxido, situando-se a mëdia dos valôres em tôr no de $0,3-0,5 \%$; tamberm neste caso os resultados são aproxima-
dos.

A distribuigão dos elementos acima citados, ao que tudo indica, não tem qualquer relagäo direta com a quantidade de $\mathrm{P}_{2} \mathrm{O}_{5}$ presente nos solos.

- aproveitamento da própria rocha carbonatitica. como matéria prima para a fabricasão de cimento ou cal, no ca so de Juquiă, não apresenta possibilidades favoräveis devido ao conteüdo extremamente elevado em öxido de magnésio. 


\section{VIII - COMPARACÃO COM OUTROS DISTRTTOS ALCALINOS}

Entre as ocorrências conhecidas no Brasiz, o complexo alcalino de Juquiă se assemelha, quanto à forma $e$ associacão de rochas, àquelas de Jacupiranga, talvez Ipanema e, em parte, a Itapirapuã (SP) e Anitäpolis (SC).Com re lacão äs estruturas de Catalão (Go), Serra Negra, Araxä, Sa litre e Tapira (MG), nas quais também se conhece carbonatito, a semelhanga ë sugestiva, embora uma conclusão seja prematu ra, por falta de estudos detalhados ou de afloramentos sufi cientes.

A ärea de Juquiă, no entanto, ë totalmente di versa das ocorrências de Lajes (SC), Pogos de Caldas (MG), São Sebastião e Cananëia (SP), ou Itatiaia (RJ e MG), onde não existem rochas carbonatiticas, ijolitos e piroxenitos.

Grande parte das diferengas entre as värias o corrências pode sex explicada considerando diversos niveis de exosão de um conduto vulcânico ideal e completo, desde a parte profunda, essencialmente plutônica, atë o edificio vulcânico. o primeiro grupo de localidades, no qual se inclui Juquia, representa partes profundas desse conduto; 0 segundo abrange as porgões superiores, tendo em pogos de Caldas seu representante extremo, com conservacão parcial da estrutura vulcânica.

No primeiro grupo ainda poderia ser considera da uma subdivisão em funcão do desenvolvimento dos carbonatitos. Localidades onde essas rochas ocorrem apenas como diques ou em pequenas massas irregulares, seriam consideradas representativas de condigões hipoabissais, corresponden do, portanto, a um nivel mais alto do que aquêle em que se formam massas carbonatiticas maiores. Evidentemente, essa caracterizagão sö tem significado muito genërico, uma vez que diques carbonatiticos podem se formar em diferentes pro fundidades. Admitindo, entretanto, a validade dêsse esquema, Juquiä e Jacupiranga representam seccões bastante pro fundas, aquête possivelmente mais baixo que êste. Alềm disso, 
as diferengas entre estas duas localidades podem ainda ter outros motivos, inclusive relacionados ao próprio material original. Jä Itapirapua, onde apenas ocorrem alguns diques carbonatiticos pouco espêssos, e Anitäpolis, onde o corpo carbonatitico é muito pequeno, seriam representantes do gru po hipoabissal.

Os numerosos complexos alcalinos com carbonati tos, em especial na Africa, apresentam os mais diversos mo dos de ocorrência e particularidades. Pela associagão petro logica global, sua distribuigäo e forma do complexo, juqui $a$ se assemelha a Palabora, que $\vec{e} j u s t a m e n t e$ considerado um representante de nivel profundo lHanekom e outros, 2955 ; Verwoerd, 1966; Gittins, 1966a, p.443-445). Juquia, no en tanto, tamberm apresenta algumas semethangas com outras ocor rências. Na localidade em questão, se os carbonatitos
realmente ocupam todo o Morro do serrote, êles correspondem
a cêrca de $15 \%$ da ârea total do complexo, proporeao oompara a cêrca de $15 \%$ da ârea total do complexo, proporeáo compará vel a muitas outras localidades congêneres. Por outro lado, a sua ärea de $2 \mathrm{~km}^{2}$ pode sex considerada mëdia em relação aos corpos carbonatiticos em geral.

Quanto à composiqão mineralögica, os carbonatitos apresentam uma grande variedade de minerais, nas mais diversas proporsones, tornando insegura uma comparagâo entre as diferentes localidades. Nas rochas do Morro do Serrote destaca-se a quantidade de minerais de estroncio e bärio, alèm da pobreza em apatita e silicatos.

Do ponto de vista quimico, as comparacões são dificeis, pois, embora carbonatitos dolomiticos sejam co muns, as referências a valôres extremamente altos de $\mathrm{MgO}$, como no caso do carbonatito interno, säo muito raras es na maioria das vêzes, relativas a diques de pequena espessura e distribuigão restrita. Esta ë uma peculiaridade que distingue Juquiä da maioria dos carbonatitos. 


\section{IX - SUMARTO E CONCLUSOESS}

1 - As rochas que ocorrem na região de juquia, constituem um tremplo tipico de associagäo de rochas alcalinas (sienitos, ijolitos, piroxenitos e peridotitos) com carbonatitos.

2 - As roohas encaixantes do complexo alcalino sâo consti tuidas por gnaisses, com quartaitos e micaxistos subor dinados.

3 - As rochas encaixantes, nas proximidades da intrusão, en contram-se modificadas por processos metassomäticos pouco intensos, caraoteriados por perda de alguns elementos a adigäo de outros; neste fenomeno, Si, A. Na $x$ sas os principais elementos envolvidos, sem entretanto evidenciar-se uma tendêneía ünica e nitida.

4 - Näo hä qualquer evidência de vulcanismo associado to complexo alcalino de irquia.

5 - O nimero de diques alaalinos, cortando as rochas do om plexo e suas encaixantes. é extremamente reduzido; nao

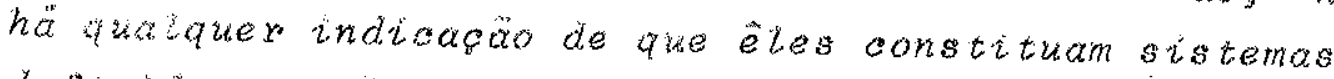
definidos e orientados, como ocorre em alguns complexios atolathos com grande nümex de diques radiats e onom $2 x+60$

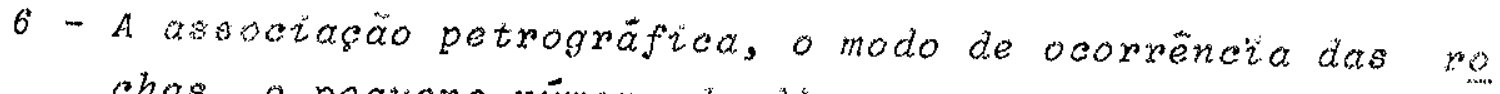
chas, o pequeno nümero de diques e a falta de evidêračas de vulsanismo indicam que a parte atualmente exposta da estrutura correspode a um nivel profundo de um conduto vuleantoo.

? - Pixsentos parecem constitury a maior parte da ärea da intrysäo, podendo estar associados a peridotitos; seguem em impoxtância os sienitos ijolitos, entre as rochas silicatadas.

8 - Os sienitos apresentam, em parte, caracteristicas izpicas de rochas intrusivas, mas em värios outros casos cos respondem a ijolitos feldspatizados e piroxenitos enriqueatdos em älcalis. 
9 - Os sienitos do Morro da casa de pedra consiztuem pequem na bossa, isolada do coxpo aloatino principal.

10 - Pexidotitos e piroxenitos, ijoititos, sienitos e carbona títos constituem a prováve sequënutia de formagà das rochas.

11 - Os carbonatitos constituem uma ünta massa arrederadada. situada no interior do complewo alcaltno pxörimo sow borda oesire, encaixada em rowhas ultrabäsicas e, subor dinadamente, em contato om ijotito.

.2 - Foram identificados dois tipos principais de carbonailm to: um mais recentes constituindo a parte centrai do Nox ro do serrote, com granulacáo fina; outro. mais antigo. de granulacáo mais grossa, constituindo a parte externa do moxro, com possive forma anelar em torno do mats ye cente.

13 - As rochas carbonatitioas do Morro do serrove sach befor sitions, prinoipalmente as da parte central, onde os teo res de MgO säo muito elevados, superando em varrias amos tras a quantidade de CaO. Dotomita e ankerita sas os caxbonatos predominants. chquanto que caterita pares o coxper em quantidade redizida no carbonatito ways.

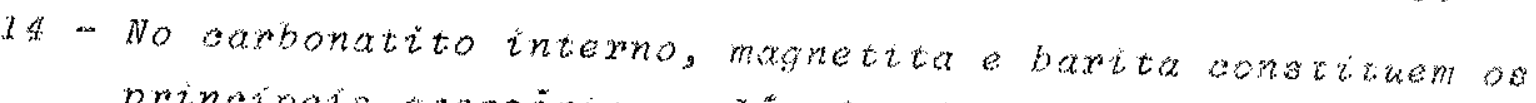

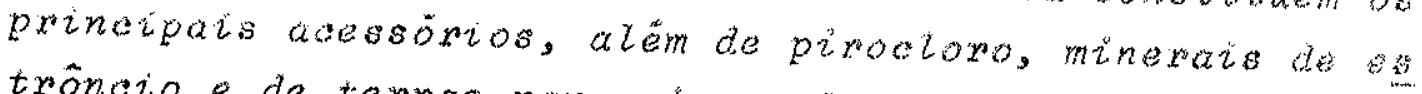
trôncio e de terras raras (monazita e ancylita). Apari... ta estä quase ausente. No carbonatito extexno predertinam magnetita, mica, apatita e dahlita, esta possivelmente se cunăäria, entre os acessoorios; barita ë bem mais rara. He nerais de estrôncio, peío que indicam as anätises quintm cas, sais menos abundantes.

is - Os teores de Ba e Sr no carbonatito interno säo ezy vados, em comparagäo aos outros carbonatitos brastitelios.

16 - Fosfatos, em grande parte secundarios e repredipitados. constituem a ünica reserva economica comprovada da örea; êles se concentram no flanco sul es subordinadamentes su doeste do Morro do serrote. Ssses minerais em parte saco 
residuais, mas podem tambèm derivar de uma toneertragao primäzia na ana de contato entre carbonatito com pirow xentito ou ijotito.

17 - A distriburgäo do niobbio, terras raras; estróncio e ba rio, nos solos xestiduar que capeiam o carbonatito, me rece ser verificada do ponto de vista economiso; essos e tementios poderiam donswitur reserva ao lado dos fos fatos ou serem subproduros em potenciat, o que poderia

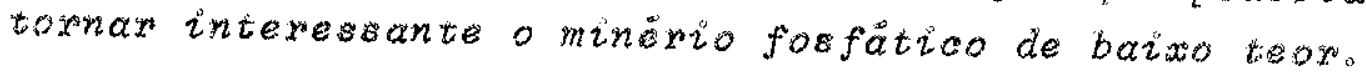

18 - As reservat indroadas de fosfatos säo avaliadas am mais de 2 mithoes de tometadas som teor atima de $15 \%$ $P_{2} O_{3}$ e mais de um mithao de coneladas eom teor de 10 a $75 \%$ de $P_{2} O_{5} ;$ exclui-se a parte donstituida por mate ritar contendo $5-20 \% P_{2} O_{5}$.

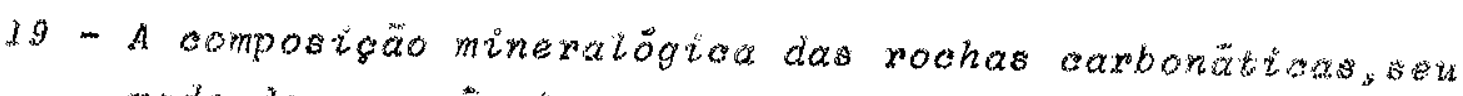

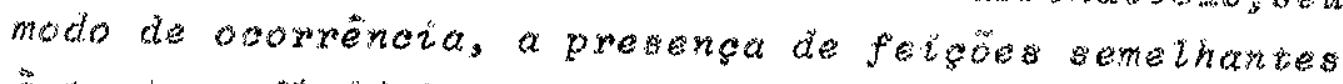

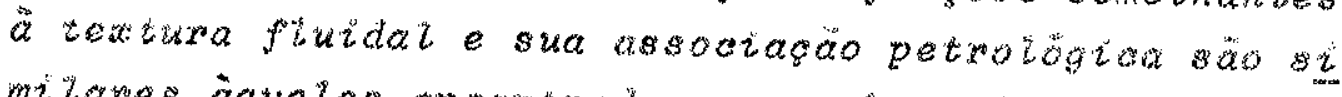
mitares aqueles encontrados em carbonativos de numero

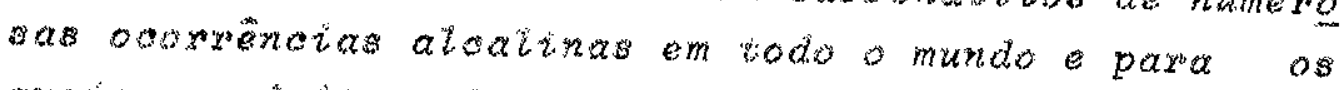

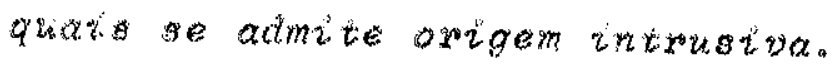




\section{$X-$ BIBLIOGRARYA}

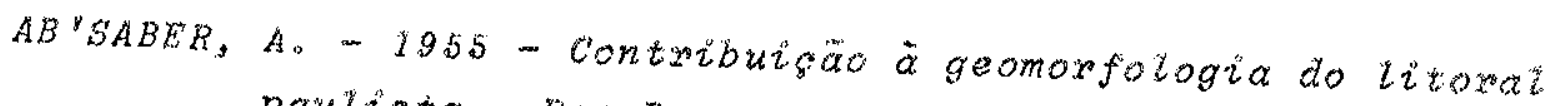
poulista - Rev.Bras.Geogr., Vot. 2\%, p.3-48.

ALMELDA, F.M. de - 1961 - Geotogia e petrologia da itha dia Tyindade - Div. Geol.Minexalogia, Monografia XVIT.

196" - Oxigem e evolugao da plataforma bxasileira - Bol.Div.Geol.Mineralogiano 34 .

AMARAL, G. - 1967- Programa para cäleutos petroquimioos lnozt ma e valöres de Nigglit em computador - Ar. XXI

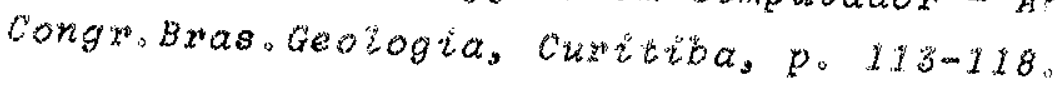

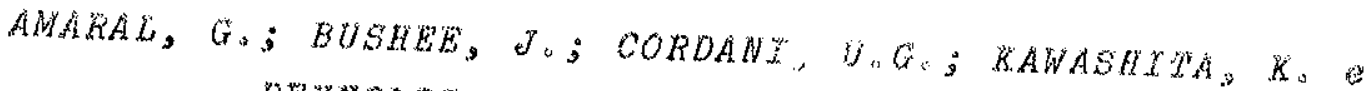
REYYNOLDS, \%.H, $-196 \%$ - POtas

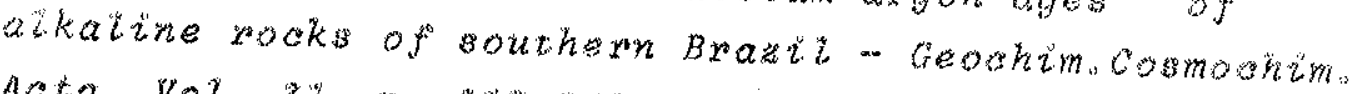

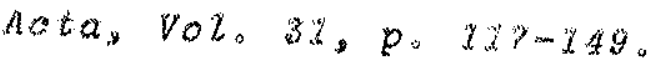

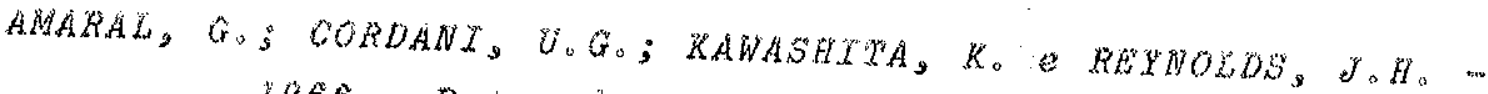
$1966^{\circ}$ - potassium-argon ages of basaltio rooks fom p. 159-189.

BATLAY, D.K. - $2966^{\circ}-$ Carbonative wolcanoes and ghallow intristions in lambia - em cambonatives - o. Fomtits

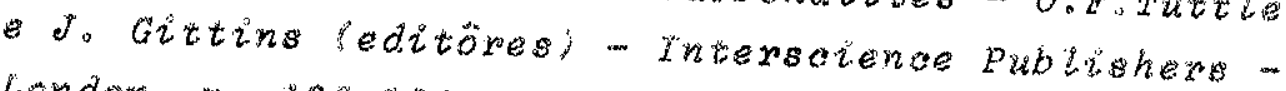
london, po $128-154$.

BARTH, WH.W. - 1952 - wheoretroat petrology - rohn witey and Sons, Ino. - New York.

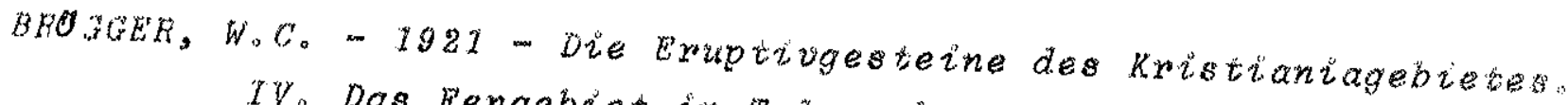

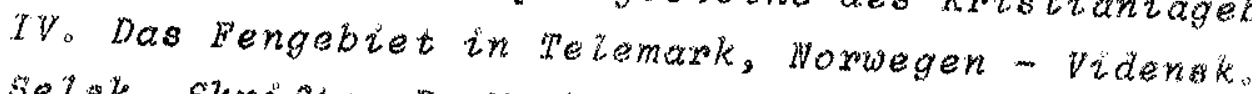
betak, skrifier I, Math, Nat, KL。 (1920), nog. 


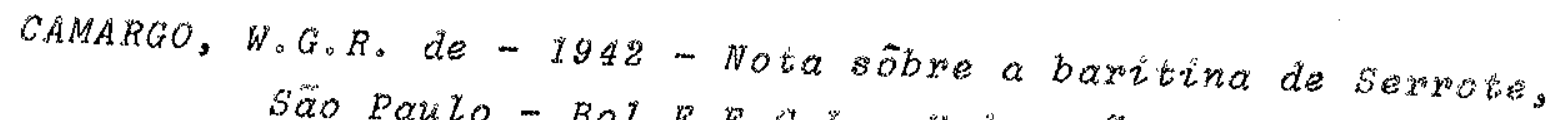

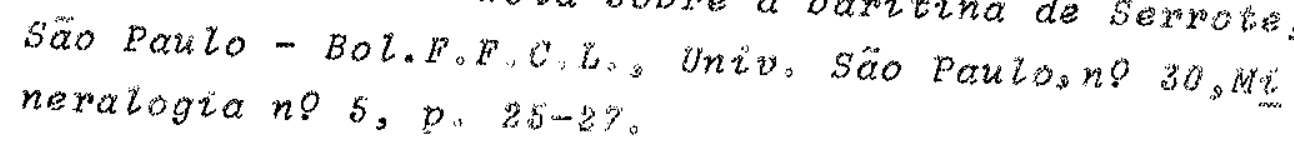

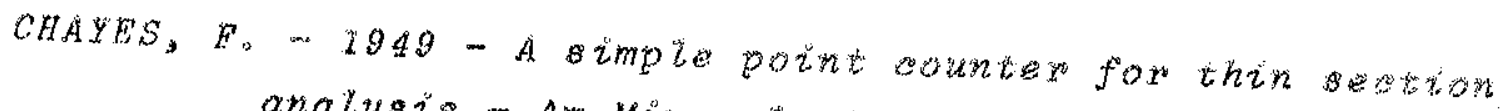

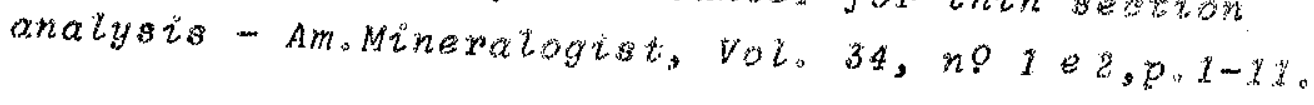

CORDANT, $U_{0} G_{1}$ e BITTENCOORT, $T_{0}-196 \%$ - Determinagöes de $t d z$ des potássio-argónio en rochas do Grupo Agurgut -

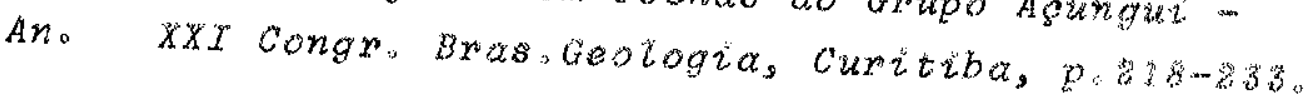

CORDAWI, U. Go GRRARDI, V.A.V. $190 \%$ - Geologra da fothe de Morretes - Bol. Univofedoparana, Geotogia no 26.

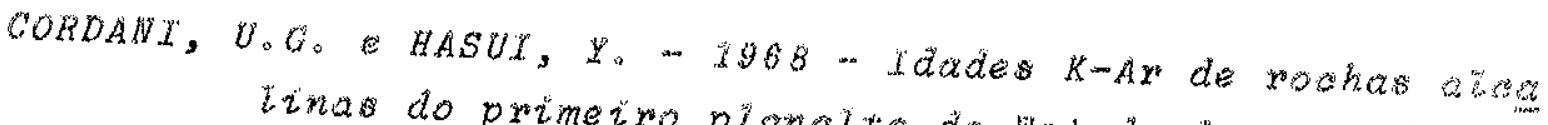
Lina do primeriro planalto do listado do parana

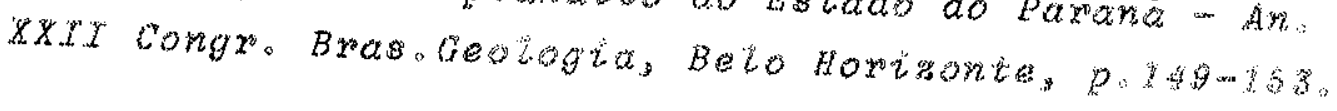

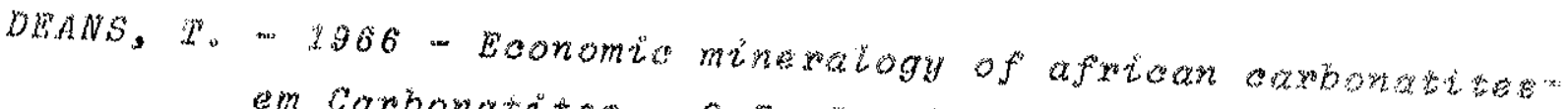
em Carbonatites - o.

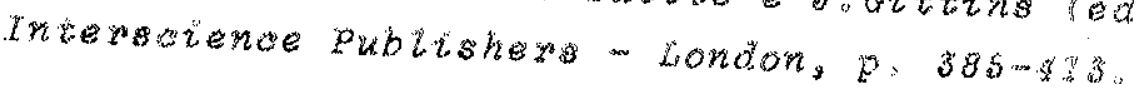

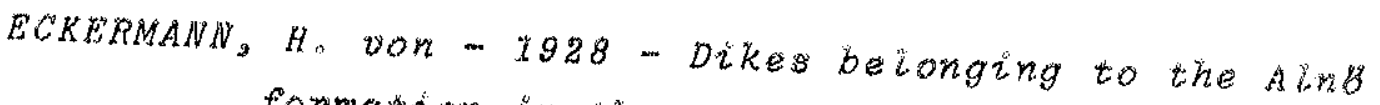

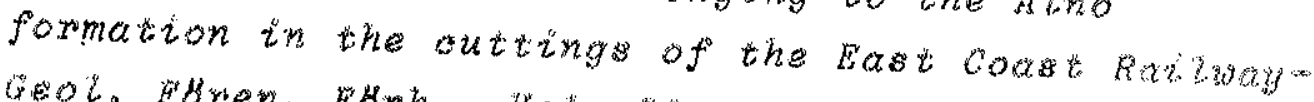

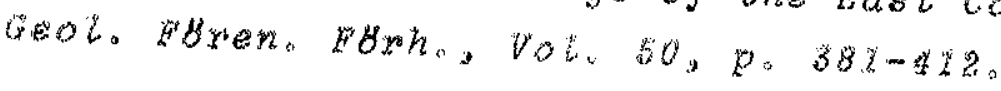

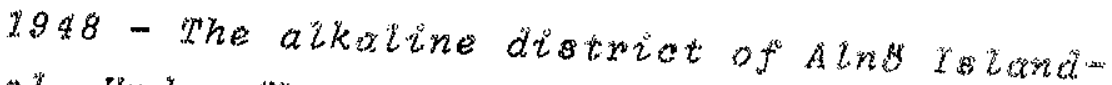

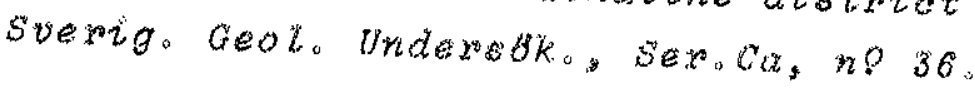

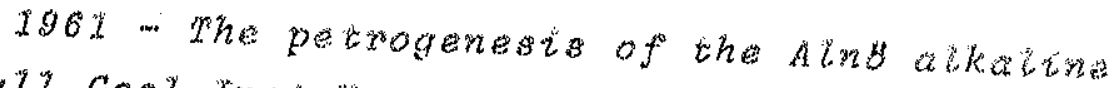

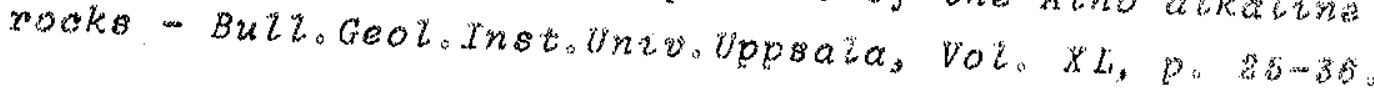

1966 - Progress of researeh on the itho

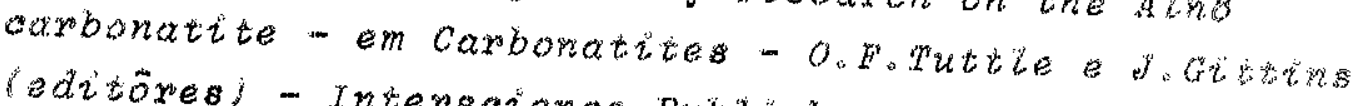
(editores) - Interscience Publishers - Londons p. 3us

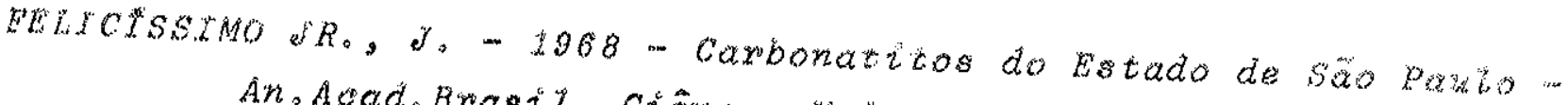

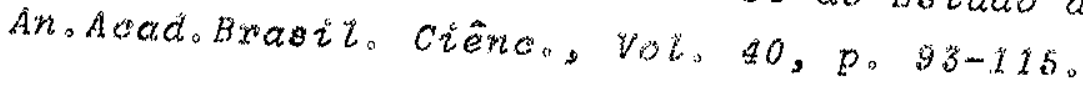


FRETTAS, R.O. de - 1951 - Ensaio söbre a tectónica moderna do Brasiz - Bol.F.F.C.Lo, Univosäo Paulosn! 130, Geologia no $6, p$. 27-41.

FUCK, R.A.; TREIN, E。 e MARINI, O.d. - 1967-Geologia petrografia dos migmatitos do Paranä - Geologia do prë-devoniano e intrusivas subsequentes da porgäo oriental do Esitado do Paranä - Bol. Paranaense de Geociências, no zz a $25, p .5-4 \%$.

GARSON, M.S. - 1959 - Stress pattern of carbonatitio and alkaline dykes at rundutu zing struoture, southern Nyasaland - proe, XXth Int. Geot.congr.,

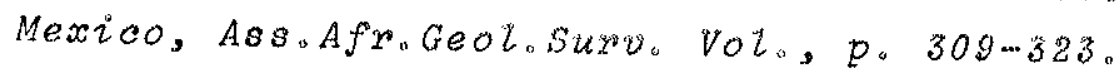

1966 - Carbonatives in Malawi - em Caxbonati... tes - O.F. Iuttie e elitutins (editores) Interscience Publishers - London, $p_{0} 3 z-7 x_{n}$

GERASTMOVSKIT, V.I. - 1956 - Geochemistry and mineralogy of nepheline syenite intrustions - Geochemistry, no 5. p. $494-510$.

1966 - Geochemicat features of agpatitio nepheline-syenites-em Chemistry of the Earth's crust, Vol. I-A.PoVinogradov leditor) - Jerusatem, p. 104-108. Traducäo do original em russo - Mosocu 1963$.

GIRARDI, V.A.V. - 1969 - Petrologia das rochas metamörficens da região de Morretes - Antonina, Pr. - Tese de doubora mento - inédito.

GITTINS, J. - $1966 a$ - Summaries and bibliographies of carbonatie complexes - em Carbonatites - O.F. Tutile e d. Gititins (editôres) - Interscience Publishers - London, p. 125-541 . 


\begin{abstract}
GITTINS, J. - 1966b - Russian views on the origin of carbonatite complexes - em Carbonatites - o.r. Tuttie e J.Gittins (editöres) - Interscience Publishers - London, $p$. 379-382。
\end{abstract}

GOLD, D.P. - 1966 - The average and typical chemical composition of carbonatites - Miner.Soc.India, IMA VD lume, p. 83-91.

GOMES, C.B. - 1967 - Petrologia do macico alcalino de ritap rapuã, S.P. - Tese de doutoramento - inêdito.

GOMES C.B. e CORDANI, U.G. - 2965 - Geocronologia do mocico alcalino àe Itapirapuã - An.AcadoBrasiz.Ciêne. Vol. 37, no 3-4, p. 497-50\%。

GUIMARAES, JE.P. e FELICISSIMO JR. J. - 1950 - Apanhado so bre os recursos mineraís do Estado de sấo paulo -

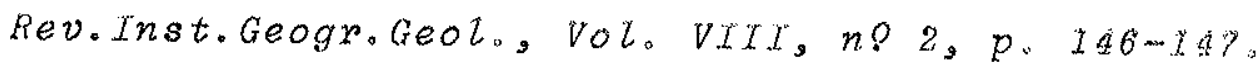

BANEKOM, H.J.; van STADEN, C.M. v。Ha; SMTT, P.J. e P.KKE, D.R. - 1965 - The geology of the palabora igneous complexw Geol.Surv.South Africa, Mem.54.

HASUI, Y. e CORDANI, U.G. - 1968 - Idades potässio-argónio de rochas exuptivas mesozörcas do oeste mineiro e sul de Goiás - An. XXII Congr.Bras.Geologia, Beto Homizonte, p. $139-143$.

HEINRICH, E.Wm. - 1966 - The geology of carbonatites - Rand MaNally \& Co. - Chicago.

JOHANNSEN, A. - 1939 e 1938 - A descmiptive petrography of the igneous rocks, Vol. I (2a ediçäo) e IV - University of Chicago Press - Chicago.

JOHNSON, R.L. - 2966 - The Shawa and Dorowa carbonatite complexws Rhodesia - em Carbonatites - O.Fotuttle e "Gitinn edi tôres) - Interscience pubitshers - London, p. $205-24 a$ 
KERR, P.F. e KULP, J.L. - 1948 - Multiple differential thermal analysis - Am.Mineralogist, Vol. 33, no 7-8, p.387 -419 .

KING, B.C. e SUTHERLAND, D.S. - 1966 - The carbonatite complexes of eastern Uganda - em Carbonatites - o. F. Tuttie ed. Gittins (editôres) - Interscience Publishers - Liondon, p. $73-126$.

KNECHT, T. - 1934 - Os minerais e minërios do Estado de são PauloBoletim de Agricultura, no üico, p. 84-85.

1940 - Os minërios näo metálicos do Estado de sấo Paulo - Bol. Inst.Geogr.Geolo, no 27, p.32-34.

1948 - Novas ocorréncias minerais nos munioiptos do

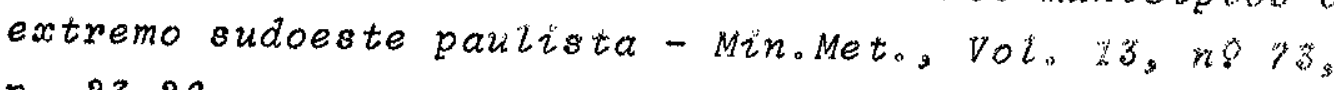
p. $23-26$ 。

KNECHT, T. e EELICISSTMO JR., Jo- 1939 - Jazida de magnetito do Morro do Serrote - Bol. InstoGeogroGeol., no 23.

KULP, J.Lo; KENT, $P_{0}$ e KERR, P. $F_{0}-1951$ - Thermal study of the Ca-Mg-Fe carbonate minerals - AmoMineralogist, Vol. 36, $n$ s. $9-10, p .643-670$.

LEONARDOS, O.H. - 1934 - Bärio - Servofom.Prod.Min., Avutso no 2. p. $17-19$ 。

1956 - Carbonatitos com apatita e pirosionoDiv. Fom.Prod.Mineral, Avulso ne 80, p. 16-1\%,

LIMA, P. de - inëdito - Descrigão das lâminas petrogräficas do Inot.Geogr. Geol. de säo Paulo.

MACTEL, D. - 1952 - Nota sôbre uma nova jazida de apatita no sul do Estado de são Paulo - Bol.Soc.Bras.Geol., Vol. ${ }_{2}$ no $1, p \cdot 3-14$. 
MATOS ALVES, C.A. - 1968 - Estudo geolögico e petrolögico do macico alcalino-carbonatitico do Quicuco (Angola) Lisboa.

MCKIE, D. - 1966 - Fenitization - em Carbonatites - O. F. Iuttie e J.Gittins (editôres) - Interscience publishers London, p. 261-294。

MELCHER, G.C. - 1954 - Nota sôbre o distrito alcalino de facupi ranga, Estado de São Paulo - DivoGeol.Min., Notas Prelim. no 84.

1965 - o carbonatito de Jacupiranga - Bot. C.L., Univ. São Paulo, no 282, Geologia n! 21.

$1966 a$ - The carbonatites of Jacupiranga, Sao Paulo, Brazil - em Carbonatites - o.F. Tuttie J. Gittins (editores) - Interscience publishers London, $p$. 169-181.

$1966 b$ - Mineralizagöes associadas aos sientios nefelinicos e caxbonatitos - Sedegeo, Vol. Especial. CAEG, pörto Alegre, $p .11-36$.

MFiLCHER, G.C. e COUTTNHO, T.M.V. - 1966-Rochas alcalinas e carbonatito de Anitäpolis, Estado de Santa Catarinam. Bol.Soc.Bras.Geol., Vol. 15, n! 1, p.59-93.

MELEI, A.J.; BITTENCOURT, I. e CORDANI, U.G. - 1965 - Reconhecimento fotogeolögico de parte do Grupo Agungui Bragantia, Vol. $24, n ? 34, p .447-474$.

MEYER, A. e BETHUNE, P. de - 1960 - The Lueshe carbonatite (Kivu, Belgian Congo) - Proc. XXI Int.Geol.Congr., Nosden, Part XIII, p. 304-309.

MORAES REGO, L.W. de - 1933 - Contribuigão ao conhecimento das formagöes prë-devonianas de. São Paulo - Inst.Astron. Geogr. de säo paulo. 
NOCKOLDS, S.R. - 1954 - Average composition of some igneous rocks - Bull. Geol.Soc.Amer., Vol. 65, no 10, p. 1007-1032.

NOCKOLDS, S.R. e ALLEN, R. - 1953 - The geochemistry of some igneous rook series. Part I - Geochim. Cosmochim. Acta, Vol. 4, no 3, p. 105-142.

PEACOCK, M.A. - 1931 - Classification of igneous rock seriesJour. Geol., Vol. 39, n! 1, p. 54-67.

POWELL, J.L.; HURLEY, P.M. e FAIRBAIRN, H.W. - 1966 - The strontium isotopic composition and origin of carbonatites - em Carbonatites - o.F.Tuttie e J. Gittins (editôres) - Interscience Publishers London, p. 365-378.

SERV.VALE RIBEIRA - Secret.Serv.obras Publ. - DAEE' Brasconsult - 1966 - Plano de desenvolvimento do Vale do Ribeira e litoral sul, Vol. III.

SETZER, J. - 1946 - Contribuigão para o estudo do clima do Estado de São Paulo - Bol. DER, Vol. IX-XI.

SILVEIRA, J.D. da - 1950 - Baixadas litorâneas quentes e ümi das - Tese de concurso à Cadeira de Geografia Físi ca da F.F.C.L. da Univ. São Pauzo.

SIMPSON, E.S.W. - 1954 - On the graphical representation of differentiation trends of igneous rocks - Geol.Mag., Vol. 91, no 3, p. $238-244$.

SØRENSEN, H. - 1960 - On the agpaitic rocks - Proc.XXI Int. Geol. Congr., Norden, Part XIII, p. 319-327.

STRAUSS, C.A. e TRUTER, F.C. - 1951 - The alkali complex at Spitzkop, Sekukuniland, Eastem Transvaal - Geol. Soc. S.Africa Trans.,Vol. 53 (1950), p. 81-130. 
VERWOERD, W.J. - 1966 - South african carbonatites and their probable mode of origin - Ann. Univ.stellenbosch, Vot. 41 , sex. A, no 2。

WARD, F.N.; LAKIN, H.W.; CANNEY, F.C. e outros - 1963 Analytical methods used in geochemical exploration by the U.S. Geological Survey - U.S. Geol. Surv. Bulz.sn? 1152, p. 66-68.

WARNE, S. St.J. - $1962-$ A quick field or laboratory staining scheme for the differentiation of the major carbonate minerals - Jour. Sedimentary Petrology, Vol. 32, n? 1, p. $29-38$.

WILLIAMS $H_{0}$; TURNER, F.J० e GILBERT, C.M. - 1955 - petrography: an introduction to the study of rocks in thin sectionW.H. Freeman and Company - San Francisco.

WINCHELL, A.N. e WINCHELL, H. - 1951 - Elements of optical mineralogy (4a. edigão) - John Wiley and Sons, Inc.New York.

WOLE, K.H.; EASTON, A.J. e WARNE, S。 - 1967-Techniques of examining and analysing carbonate skeletons, minerals and rocks - em Carbonate rocks - G.V. Chilingar; H.J. Bissel e R.W. Faixbridge (editôres)-Developments in sedimentology, Vol. $9 B$ - Elsevier - Amsterdam p. $253-341$ 。

WYLLIE, P.J. - 1966 - Experimental studies of carbonatite problems: The origin and differentiation of carbonatite magmas em Carbonatites - O.F. Tuttie e J.Gittins (editôres) Interscience Publishers - London, p. 311-352. 
Fotomicrografia 1 Melanita (centro). associada com biotita, proximo ao con tato de um veio de composigao sieniti= ca com ijolito. A melanita formoume a partir de egirina augita preexisten te. A direita, nefelina circundada por feidspato potassivo (p. 37). Aumento 27 vêzes.

Fotomicrografia 2: Anflbotio sodico com borda de egirinamaritas no conta to entre gnaise e sientito no Morro

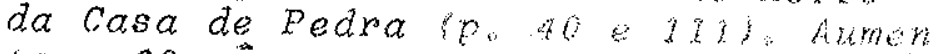
to: 69 vezzes. 
Eotomicrografia $3:$ Cxistais idiomorfi cos de anfibstio, total ou paratialmen te substituidos por egirinamangita e biotita, em sienito do Morro da Casa de Pedra. O crista maior ainda apre senta nucleo inalterodo (p.49). Aumen to: 27 vezes (com condensador).

Fotomicrografia 4 "Formagăo de minem ral opaco nas bordas de titanita em contato com cancrinita $(p .50)$. Aumen to: 27 vezes (com condensador). 
Fotomicrografias s e 6 simoxento aum gitico e biotita com bordar de egixina -augita, de hatito acieular. Estädio inicial da alcalinizacao de rochas pi roxeniticas ricas em plagioolasio $1 \mathrm{mi}$ nerais alaros) (po56). Aumento: $2 \%$ verses。 
Fotomicrografia $7:$ Sienito originado por feldspatizasao de ijolito. Egirina - augita (cinza escuro) e nefelina liur va) estao circundadas por feldspato po tassico, opticamente continuo os cris tais de nefelina podem apresentar habi to idiomórfico e muitos dêles sao ar redondados, especialmente nos cantos (p.56). Aumento: 27 vezes (com con densador.

Fotomicrografia $8:$ Dique piroxenitioo (camptonito) com fenocristais idiomorm ficos de piroxentio e olivina (p. 64). Aumento: 27 vẽzes. 
Fotomicrografia $9:$ Fenocristal zonado de piroxênio em dique piroxenitico. 0 zonamento e devido a presença de numerosas inclusóes aciculares, orientadas em diversas diregöes. Este tipo de zo namento tambem ocorre nas rochas pixo xeniticas (p. 25 e 65). Aumento: 27 vëzes。

Fotomiarografia 10: Carbonatito inter no com duas geracóes de carbonatos. oT carbonatos de corr escura, mais finos, são posteriores (p。80e 96).Aumento: 27 vêzes。 
Fotomicrografia 11: Ancylita lcinza escurol com bordas semi-alteradas barita (branco, a esquerda) no carbo natito interno $(p, 93)$. Aumento: 27 vêzes。

Fotomicrografia 12 : Cristais de piro cloro, tendendo ao idiomorfismo, no carbonatito interno. os carbonatos säo de duas geragöes (cinza claro e cinza escuro) ( $p$. 92). Aumento: 2 ? vêzes。 
Fotomicrografia 13 : Contato entre fe nito (direita) e gnaisse (esquerda). o fenito é composto por plagioctásio (branco), piroxênio (cinza escuro, fi no), magnetita (preto), cristais maio res de biotita (cinza) e alguns restos de quartzo ( $p .113$ ). Aumento : 27 vê zes.

Fotomicrografia 14: Plagiocläsio (cin za escuro, geminasão polissintëtical $\bar{e}$ piroxênio (cinza, alto relêvo, à direi ta) substituindo quartzo, em gnaisse fenitizado. Pouco feldspato alcalino (cinza médio, canto inferior direito). Nos dois tipos de feldspato, ha alguns restos de quartzo (branco, embaixo) (p. 113). Aumento: 69 vêzes, polariza dores cruzados. 


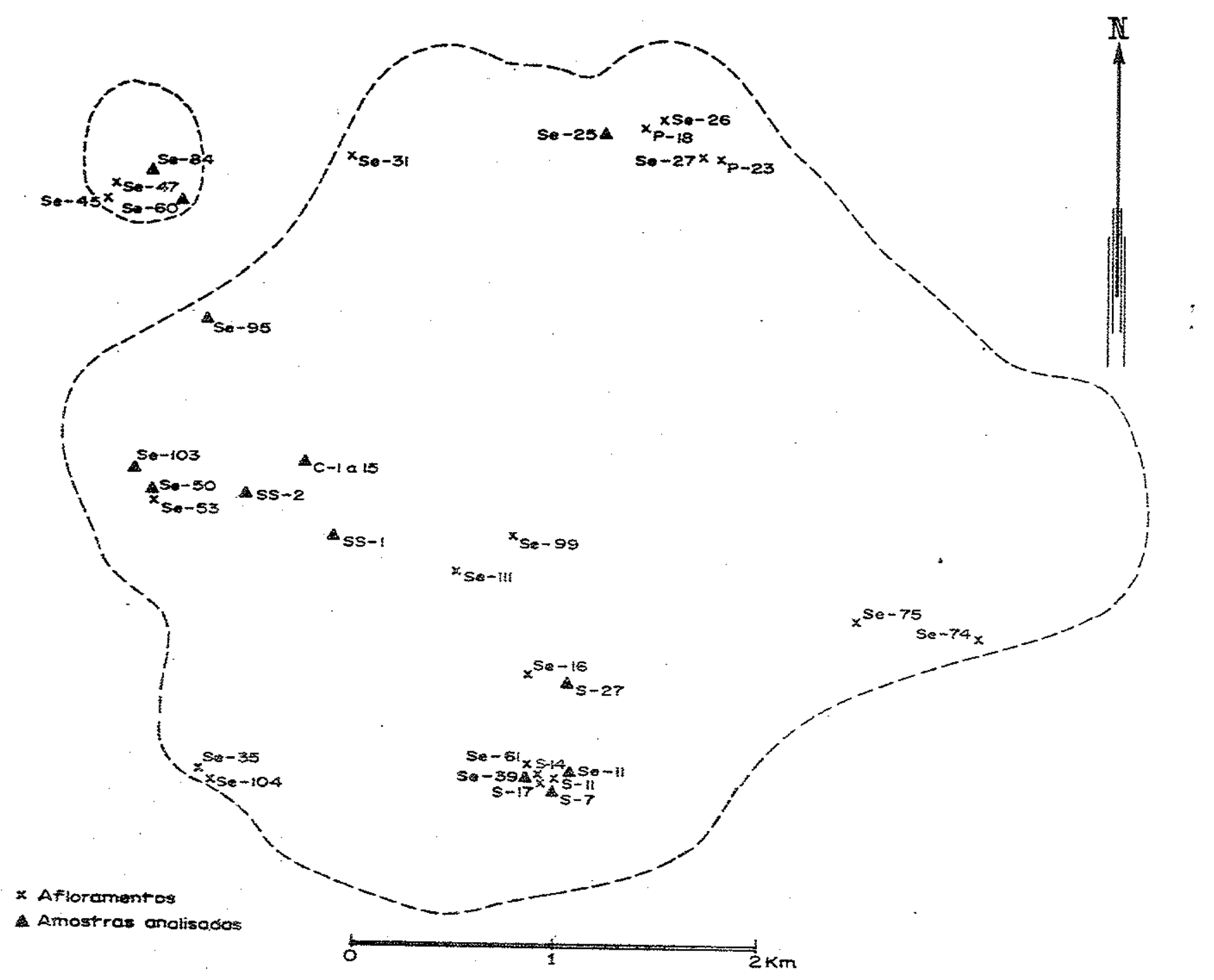

Anexo 3: Localizacio das amostras citadas no texto. 
